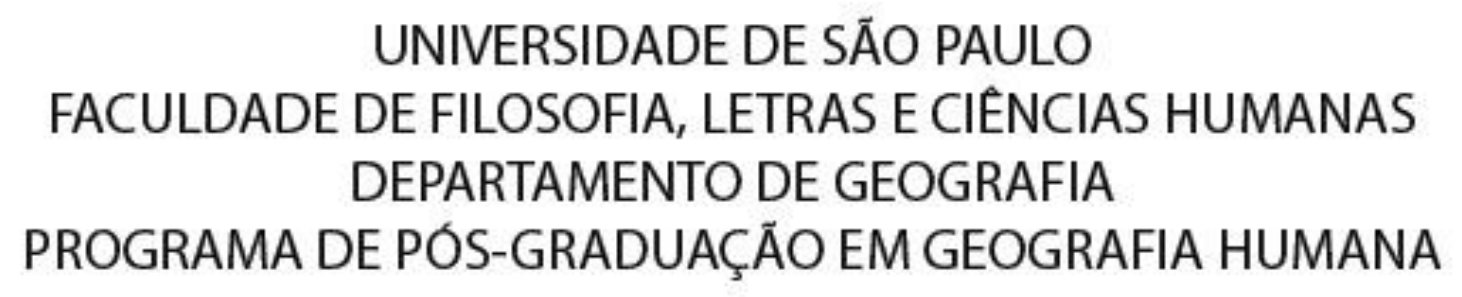

TESE DE DOUTORADO

A BIODIVERSIDADE NA INDÚSTRIA DE COSMÉTICOS: contexto internacional e mercado brasileiro

LAIS MOURÃO MIGUEL

São Paulo

2012 


\author{
UNIVERSIDADE DE SÃO PAULO \\ FACULDADE DE FILOSOFIA, LETRAS E CIÊNCIAS HUMANAS \\ DEPARTAMENTO DE GEOGRAFIA \\ PROGRAMA DE PÓS-GRADUAÇÃO EM GEOGRAFIA HUMANA
}

TESE DE DOUTORADO

\title{
A BIODIVERSIDADE NA INDÚSTRIA DE COSMÉTICOS: contexto internacional e mercado brasileiro
}

Laís Mourão Miguel

\begin{abstract}
Tese apresentada ao Programa de Pós-Graduação em Geografia Humana do Departamento de Geografia da Faculdade de Filosofia, Letras e Ciências Humanas da Universidade de São Paulo para a obtenção do título de Doutor em Geografia
\end{abstract}

Orientador: Prof. Dr. Wanderley Messias da Costa

São Paulo

2012 


\section{DEDICATÓRIA}

A minha mãe, Mara, e irmã, Maysa, por todo amor e apoio.

Ao meu pai, Adonis, e a minha querida avó, Maria Ignêz, com muita saudade. 


\section{AGRADECIMENTOS}

Expresso aqui meus agradecimentos a todos que contribuíram de algum modo na execução deste trabalho.

Ao Prof. Dr. Wanderley Messias da Costa, orientador e amigo, por toda confiança e dedicação na orientação da tese de doutorado.

À Fundação de Amparo à Pesquisa do Estado de São Paulo (FAPESP) que concedeu uma bolsa, tornando possível o desenvolvimento pleno de diversas etapas de trabalho.

À Coordenação de Aperfeiçoamento de Pessoal de Nível Superior (CAPES) pelo apoio financeiro para a realização do estágio de Doutorado-Sanduíche em Paris e à Prof ${ }^{a}$. Drª . Martine Droulers que me recebeu no Institut des Hautes Études de l'Amérique Latine (IHEAL)/Université Paris III - Sorbonne Nouvelle durante o período de estudos em Paris.

Agradeço a todos os representantes das empresas, técnicos, pesquisadores e professores das Universidades, Centros e Institutos de Pesquisa que me receberam e colaboraram nas etapas de trabalho de campo, em especial ao Luiz Gustavo Martins da Associação Brasileira de Cosmetologia (ABC) e da empresa Mapric, ao Ulisses Sabará e à Ingrid Simkus Ramos da Beraca Sabará, à Cristiane de Moraes da Union for Ethical BioTrade (UEBT), ao Eric Chaisse do CRIEPPAM, e à Maud Reboul da L'Occitane en Provence, à Elisabeth Vidal da FranceAgrimer e ao Christian Gazquez e Giovanna Restivo do Pôle de Compétitivité Parfums, Arômes, Senteurs, Saveurs (PASS).

A minha mãe por toda compreensão, incentivo e amor, como também aos meus familiares e, especialmente, à Maysa, irmã e companheira por toda vida. 
Ao Fumio Nishiyama por todas as conversas produtivas que tanto me ajudaram ao longo desta jornada.

Agradeço, também, à Circe Inês Dietz e Marinalva Lima, pelo apoio.

Aos amigos Rafael Faleiros Pádua e Adrien Rouillon, Graziela Luz Castello, Ligia Amstalden Rubega e, principalmente, à Maysa Mourão Miguel, que generosamente colaboraram em algumas etapas do trabalho.

Aos professores do Departamento de Geografia da FFLCH/USP, especialmente à Profa ${ }^{\text {. }}$ Dra Ana Fani e ao Prof. Dr. Hervé Théry. E, também, aos professores membros da banca de qualificação, Prof. Dr. Márcio Cataia e Prof. Dr. Fabio Betioli Contel, que contribuíram com sugestões importantes para o desenvolvimento da pesquisa.

Finalmente, mais uma vez, agradeço a TODOS que apoiaram na realização e conclusão desta tese de doutorado. 


\section{RESUMO}

MIGUEL, Laís Mourão. A Biodiversidade na Indústria de Cosméticos: contexto internacional e mercado brasileiro. 2012. 259f. Tese (Doutorado em Geografia) - Faculdade de Filosofia, Letras e Ciências Humanas, Universidade de São Paulo, São Paulo, 2012.

As transformações recentes no perfil dos mercados de consumo de cosméticos, aliadas aos avanços das pesquisas em biotecnologia, têm propiciado novas oportunidades para diversos segmentos industriais contemporâneos. Uma das inovações representativas desse processo está associada ao desenvolvimento de produtos cosméticos baseados na crescente utilização da biodiversidade de origem vegetal.

Tendo como base geral as relações entre a biodiversidade, a biotecnologia e a bioindústria, o objetivo central deste trabalho consiste em analisar algumas experiências em curso na produção de cosméticos derivados de diversos tipos de ativos naturais e, ao mesmo tempo, avaliar as tendências e os desafios representados por esse segmento industrial.

Constituem objeto de levantamento empírico, um grupo selecionado e representativo desse segmento de indústrias de diferentes portes instaladas no Brasil, destacando-se aquelas localizadas no estado de São Paulo, onde ocorre atualmente a sua maior concentração, e também na região de Provence-Alpes-Cotê D'Azur, localizada na França. São examinadas sob essa perspectiva, também, algumas experiências internacionais mais conhecidas e que têm se destacado no mercado mundial de cosméticos justamente pela sua liderança e seu pioneirismo nessa modalidade de inovação.

Palavras Chave: Cosméticos, Biodiversidade, Biotecnologia, Bioindústria, Inovação. 


\section{ABSTRACT}

MIGUEL, Laís Mourão. Biodiversity in Cosmetics Industry: international context and the Brazilian market. 2012. 259f. Thesis (Doutorate in Geography) - Faculdade de Filosofia, Letras e Ciências Humanas, Universidade de São Paulo, São Paulo, 2012.

The recent changes in the profile of consumer markets for cosmetics, allied to advances in biotechnology research have provided new opportunities for several contemporaneous industries segments. One of the representative innovations of this process is associated to the development of cosmetic products based on the growing use of the biodiversity with vegetal origin.

Based on the relationships between biodiversity, biotechnology and the bio-industry, the objective of this thesis is to analyze some experiences in progress about the production of cosmetics derived from various types of natural assets and, at the same time, evaluate trends and challenges represented by this industrial segment.

Constitute object of empirical study, a selected and representative group of this industries segment from different sizes located in Brazil, especially those located in the state of São Paulo, where there is currently its higher concentration, and also in the region of Provence-Alpes-Côte d'Azur, located in France. Some of the most know international experiences have been examined from this perspective, as well. Those that have been prominent in the global cosmetics market precisely for its leadership and its pioneering on this type of innovation.

Key Words: Cosmetics, Biodiversity, Biotechnology, Bioindustry, Innovation. 


\section{RÉSUMÉ}

MIGUEL, Laís Mourão. La Biodiversité dans I'Industrie des Cosmétiques: contexte international et marché brésilien. 2012. 259f. Thèse (Doctorat en Géographie) - Faculdade de Filosofia, Letras e Ciências Humanas, Universidade de São Paulo, São Paulo, 2012.

Les récents changements dans le profil des marchés de consummation des cosmétiques, alliés aux progrès des recherches en biotechnologie, offrent de nouvelles opportunités pour différents secteurs industriels. Une des innovations représentatives de ce processus est liée au développement croissant de produits cosmétiques basés sur l'utilisation de la biodiversité végétale.

En se basant sur les relations entre la biodiversité, la biotechnologie et la bioindustrie, l'objectif de ce travail est d'analyser certaines expériences actuelles de production de cosmétiques dérivés plusieurs types de actifs naturels et, dans le même temps, d'évaluer les tendances et défis posés par ce secteur industriel.

L'étude expérimentale porte sur un groupe représentatif d'industries de ce secteur, de tailles variées et installées au Brésil, en particulier celles situées dans l'état de São Paulo, où elles sont actuellement le plus concentrées, et aussi dans la region Provence-Alpes-Cotê D'Azur, situé en France. Sont également examinées dans cette perspective quelques expériences internationales plus connues et qui jouent un grand rôle sur le marché mondial des cosmétiques précisément pour leur primauté et leadership sur cette voie d'accès à l'innovation.

Mots-clés: Cosmétiques, Biodiversité, Biotechnologie, Bioindustrie, Innovation. 


\section{SUMÁRIO}

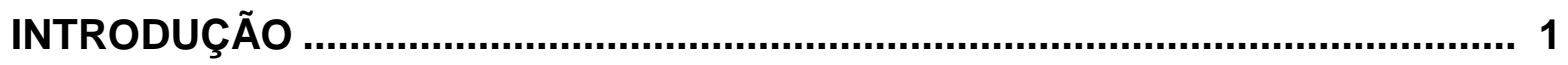

CAPÍTULO 1 - A INDÚSTRIA DA BELEZA.................................................... 10

1.1 A Constituição da Indústria da Beleza ........................................................... 11

1.2 Os Novos Pilares da Indústria de Cosméticos: juventude, beleza e bem-estar 22 1.3 A Valorização da Biodiversidade e Sustentabilidade Ambiental na Indústria de Cosméticos 40

CAPítUlo 2 - A INDÚSTRIA de hIGIENe PESSOAL, PERFUMARIA E COSMÉTICOS: panorama internacional e nacional do setor ..........................57

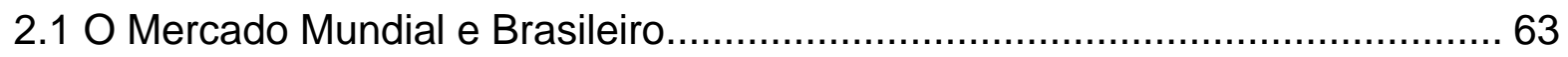

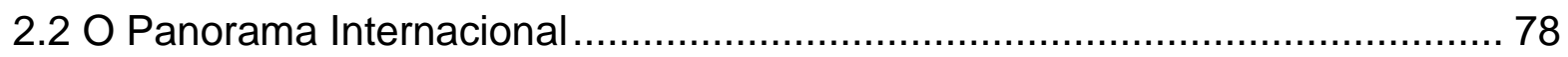

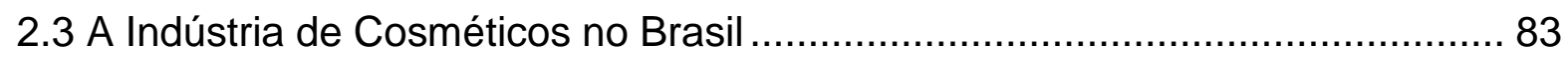

2.4 Normatização, Certificação e Legislação...................................................... 93

CAPÍTULO 3 - OS CIRCUITOS DE INOVAÇÂO DOS COSMÉTICOS: desenvolvimento de novos produtos e processos industriais ....................... 98

3.1 Tecnologias da vida: uso da informação genética e biológica ......................... 99

3.2 Pesquisa e Desenvolvimento (P\&D) de Ingredientes Ativos ....................... 107

3.3 As Matérias-Primas e os Insumos: dos tradicionais aos inovadores ............. 115

3.4 Tendências de P\&D em cosméticos: nanocosméticos, cosmecêuticos, nutracêuticos e nutracosméticos 123

3.5 Bioprospecção e Marcos Regulatórios 133 
CAPítulo 4 - TENDÊnCIAS E PERSPECTIVAS do SEGMENTO DE BIOCOSMÉTICOS: panorama internacional e nacional

4.1 O Segmento dos Biocosméticos: quadro geral 144

4.2 Dinâmica de Produção e Distribuição de Matérias-Primas Tradicionais e Inovadoras.

4.3 Principais Indústrias Internacionais na Produção de Biocosméticos 156

4.3.1 Experiências Pioneiras do Segmento: os biocosméticos em Provence-Alpes-

Cotê D'Azur, França 160

4.4 Biocosméticos no Brasil 173

4.4.1 Biolndústrias de Insumos. 185

4.4.2 O Segmento Emergente das Bioindústrias na Amazônia Brasileira 190

4.5 Certificações dos Biocosméticos 194

CONSIDERAÇÕES FINAIS 200

BIBLIOGRAFIA 207 


\section{LISTA DE FIGURAS}

Figura 1 - Exemplos de Processos Associados à Biotecnologia .................................... 102

Figura 2 - Tipo e Origem dos principais ingredientes ativos utilizados em cosméticos..... 109

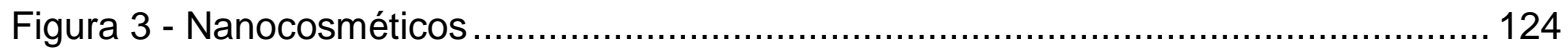

Figura 4 - Cosmecêuticos, Nutracêuticos e Nutricosméticos........................................ 128

Figura 5 - Cultura de Lavanda em Provence-Alpes-Côte d'Azur ................................... 165

Figura 6 - Fábrica da L'Occitane na região de Provence-Alpes-Côte d'Azur .................... 168

Figura 7 - Principais Operações da BERACA com os Insumos da Biodiversidade ........... 187

Figura 8 - Certificação de Cosméticos Biológicos .............................................................. 196

Figura 9 - Certificação dos Cosméticos Ecológicos ...................................................... 197

\section{LISTA DE GRÁFICOS}

Gráfico 1 - Proporção de População com 60 anos ou mais no Mundo e no Brasil entre 1950 e 2050

Gráfico 2 - Distribuição Global do Setor de Cosméticos: crescimento (\%) entre 2007 e 2008 e faturamento em 2008 (US\$ bilhões)

Gráfico 3 - Participação no Consumo de Produtos Anti-idades por grandes regiões em 2010

Gráfico 4 - Mercado de Consumo Mundial de Cosméticos entre 2006 e 2011

(US\$ bilhões)

Gráfico 5 - Evolução do market share do setor industrial de cosméticos por regiões entre 2003 e 2010

Gráfico 6 - Principais Mercados de Consumo de Fragrâncias no Mundo em 2009 e 2010 (milhões de US\$)

Gráfico 7 - Destino das Exportações Brasileiras em Óleos Essenciais, Perfumes,

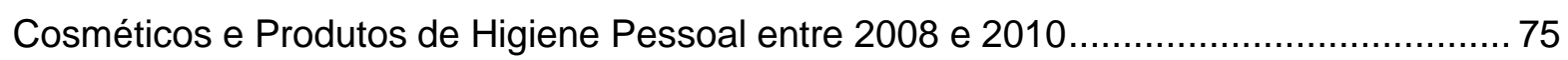

Gráfico 8 - Representatividade das Exportações Brasileiras em 2011 .............................. 76

Gráfico 9 - Origem das Importações Brasileiras em Óleos Essenciais, Perfumes,

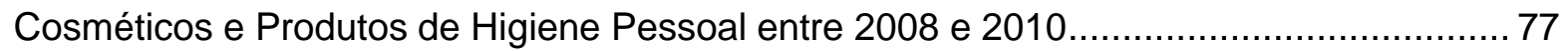

Gráfico 10 - Representatividade das Importações Brasileiras em 2011 ............................ 78

Gráfico 11 - Distribuição da Indústria de Cosméticos no Mundo em 2009 .......................... 79

Gráfico 12 - Indústrias Líderes do Setor no Mundo em 2008 ........................................... 81 
Gráfico 13 - Evolução do Faturamento da Indústria de Higiene Pessoal, Perfumaria

e Cosméticos no Brasil entre 1996 e 2011 (R\$ bilhões) .86

Gráfico 14 - Distribuição da Mão de Obra empregada no Setor de Cosméticos

em 2011. 88

Gráfico 15 - Participação da Indústria de Cosméticos no Mercado Brasileiro em 2009......90

Gráfico 16 - Distribuição de Patentes em Cosméticos de Cuidado da Pele por país de origem dos depositantes entre 2006 e 2010.

Gráfico 17 - Distribuição de Patentes em Produtos Cosméticos por grupos

tecnológicos entre 2006 e 2010

Gráfico 18 - Evolução do Mercado de Biocosméticos no Mundo entre 2005 e 2010

(bilhões de US\$)

Gráfico 19 - Crescimento do Segmento de Biocosméticos no mundo entre 2009/2010 ... 145

Gráfico 20 - Distribuição de Biocosméticos no Brasil, nos EUA e na Europa em 2009 ... 147

Gráfico 21 - Evolução do Mercado dos biocosméticos na França entre 2006 e 2009 ...... 161

Gráfico 22 - Distribuição do Segmento de Biocosméticos na França em 2007 162

Gráfico 23 - Culturas Orgânicas de Plantas Aromáticas e Medicinais na França em 2007 (hectares)

Gráfico 24 - Evolução do Segmento de Biocosméticos no Brasil entre 2005 e 2010

(milhões de $\mathrm{R} \$$ )

Gráfico 25 - Indústrias Líderes no Mercado de Biocosméticos no Brasil em 2010

\section{LISTA DE MAPAS}

Mapa 1 - Exportações de Óleos Essenciais, Perfumes, Cosméticos e Produtos de Higiene Pessoal no Mundo - 2011

Mapa 2 - Importações de Óleos Essenciais, Perfumes, Cosméticos e Produtos de Higiene Pessoal no Mundo - 2011

Mapa 3 - Indústrias de Higiene Pessoal, Perfumaria e Cosmético no Brasil

Mapa 4 - Polo de Competitividade PASS - França

Mapa 5 - Produção de Cosméticos e Derivados na região de Provence - França

Mapa 6 - Natura: unidades de produção e distribuição de cosméticos, perfumes

e produtos de higiene pessoal

Mapa 7 - Beraca: unidades de produção e distribuição de insumos 


\section{LISTA DE QUADROS}

Quadro 1 - Insumos e Processos Tecnológicos de Setores Industriais Correlatos

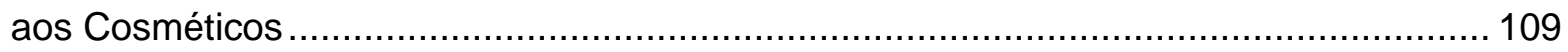

Quadro 2 - Principais Óleos Essenciais Produzidos no Mundo......................................117

Quadro 3 - Principais Espécies da Amazônia utilizadas em Cosméticos ......................... 121

Quadro 4 - Exemplos de Matérias-primas em Cosmecêuticos...................................... 129

Quadro 5 - Características dos Cosméticos com Ativos Naturais e Naturais/Orgânicos .. 143

Quadro 6 - Panorama Atual das Principais Indústrias Mundiais no Segmento

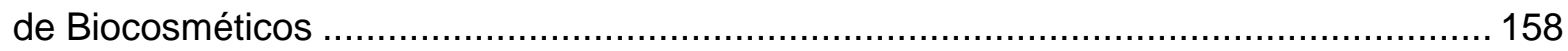

Quadro 7 - Panorama Atual da Indústria Brasileira no Segmento de Biocosméticos ....... 177

Quadro 8 - Principais Indústrias Nacionais de Insumos para Cosméticos* …................. 185

Quadro 9 - Principais Bioindústrias na Amazônia Brasileira........................................... 190

Quadro 10 - Principais Selos de Certificação de Produtos naturais e/ou Orgânicos ........ 195

\section{LISTA DE TABELAS}

Tabela 1 - Principais Mercados de Consumo de Produtos Cosméticos, de Higiene Pessoal e Perfumaria em 2010 .66

Tabela 2 - Principais Exportadores Mundiais de Óleos Essenciais, Perfumes, Cosméticos e Produtos de Higiene Pessoal em 2011 (milhões de US\$) .70

Tabela 3 - Principais Importadores Mundiais de Óleos Essenciais, Perfumes, Cosméticos e Produtos de Higiene Pessoal em 2011 (milhões de US\$) 73

Tabela 4 - Evolução do Emprego na Indústria de Cosméticos no Brasil entre 1994 e 2011

Tabela 5 - Evolução do Market-Share da Indústria de Cosméticos no Brasil entre 2001 a 2009

Tabela 6 - Ranking das Principais Indústrias de Cosméticos Investidoras em P\&D em 2009/2010 (milhões de libras).

Tabela 7 - Processos autorizados pelo CGEN entre 2002 e 2010 138

Tabela 8 - Principais Países Exportadores de Óleos Essenciais, Resinas e Terpênicos em 2011

Tabela 9 - Principais Matérias-Primas Comercializadas na União Europeia em 2003 (em milhões de euros)

Tabela 10 - Importações e Exportações de Óleos Essenciais do Brasil em 2011 (milhões de US\$ e toneladas) 
Tabela 11 - Comercialização de Produtos Florestais Não-Madeireiros da Amazônia -2006 (toneladas)

Tabela 12 - Produção de Lavanda e Lavandin em Provence-Alpes-Côte d'Azur em 2009 .... 166

Tabela 13 - Investimentos em P\&D e Inovação da Natura entre 2007 a 2010 183

Tabela 14 - Ativos Vegetais Certificados pela Natura entre 2005 e 2010. 184 


\section{INTRODUÇÃO}

O tema deste trabalho integra o atual debate sobre as novas tendências do uso econômico e sustentável da biodiversidade e os desafios representados pelos novos paradigmas, ancorados na aliança entre ciência, tecnologia, inovação e os setores produtivos industriais contemporâneos mais avançados. Em um ambiente de intensa competição internacional, os esforços da competência científica e da inovação tecnológica e, mais precisamente, da capacidade de transformar conhecimentos em processos e produtos industriais valorizados, colocam a biodiversidade no foco do debate atual sobre as diversas experiências envolvendo novas tecnologias e os recentes sistemas de produção.

No que se refere à biodiversidade, o Brasil ganha excepcional força a esse respeito no cenário internacional, já que o país possui as maiores reservas de recursos naturais, diversos biomas e a mais rica biodiversidade tropical do mundo. Estima-se que o Brasil concentre mais de $20 \%$ do total mundial de espécies inventariadas e as plantas e os microrganismos existentes no território brasileiro e especialmente na Amazônia se destacam entre toda essa megabiodiversidade (MMA, 2012). Essa riqueza natural se traduz em um valor incalculável e ao mesmo tempo pressupõe um enorme potencial para diversas experiências de aproveitamento desses recursos.

Diante desse contexto, as últimas décadas têm registrado um crescimento do interesse nos produtos sob o rótulo de "naturais" e no caso da biodiversidade, ela ganha valor estratégico sobre seus possíveis usos industriais e econômicos. O desenvolvimento de produtos derivados de ativos naturais está basicamente associado às indústrias de cosméticos (higiene 
pessoal, perfumaria e cosméticos stricto sensu), alimentos e bebidas (nutracêuticos, concentrados e energéticos) e de fitomedicamentos (fármacos derivados direta ou indiretamente de espécies vegetais).

Mediante a tendência dos produtos "naturais", "orgânicos", "verdes" ou "bio", os mercados consumidores apresentam atualmente crescente sofisticação e novas exigências quanto ao desempenho dos produtos naturais que incorporam a biodiversidade vegetal frente aos produtos convencionais do setor em geral. Essa tendência tem sido observada em várias partes do mundo, sobretudo, nos países da União Europeia, Estados Unidos e Japão, que possuem mercados mais consolidados e cada vez mais adeptos dessas campanhas. Alguns estudos do segmento apontam que o mercado internacional de produtos naturais para cuidado pessoal segue crescimento médio anual avaliado entre $8 \%$ e $25 \%$ e mercados de produtos sintéticos apresentam evolução inferior em torno de 3\% e 10\% (EUROMONITOR, 2011).

Os cosméticos estão cada vez mais especializados e personalizados de acordo com o público consumidor, alcançando todas as faixas etárias, gêneros, classes sociais, pessoas com diferentes biotipos e grupos culturais. Os inúmeros tipos de produtos, sejam básicos ou preparados sofisticados de alta qualidade e eficácia, prometem não apenas embelezar, mas também rejuvenescer, alterar e corrigir a aparência, representando assim importante papel no hábito das sociedades contemporâneas, especialmente nos grandes centros urbanos de todo o mundo.

O uso de diversos produtos que prometem acabar ou minimizar os sinais de envelhecimento, modelar o corpo ou corrigir imperfeições são apenas alguns dos mecanismos de uma sociedade que cada vez mais valoriza hábitos saudáveis e atitudes relacionadas à juventude, beleza e bem-estar. Desse 
modo, os cuidados de beleza cada vez mais se confundem com os cuidados de higiene, saúde e estes comportamentos são frequentemente reforçados na publicidade e meios de comunicação. No período atual, configura-se uma tendência que envolve o "ser saudável" para "ser belo" e vice-e-versa.

É nesse contexto que a indústria de cosméticos cada vez mais tem se destacado como protagonista do universo da beleza e do bem-estar na atualidade. Desde as últimas décadas, os indicadores do consumo de produtos de higiene pessoal, perfumes e cosméticos apontam um mercado em forte expansão, comprovado pelo crescimento de quase 10\% no período entre 2010 e 2011. Além de possuir o maior crescimento do consumo desses produtos nos últimos anos, o Brasil concentra o terceiro maior mercado consumidor do mundo, perdendo apenas para os Estados Unidos e 0 Japão (EUROMONITOR, 2012).

Diante desse quadro, diferentes opções de cosméticos para o rosto, os cabelos e o corpo são desenvolvidos para atender esse crescente mercado consumidor e as estratégias dessa indústria são cada vez mais sedutoras e levadas à sua coerção mais imperativa, sendo frequentemente lançados novos nichos de mercado, novos produtos ou até mesmo apenas um incremento (“upgrade”) da versão já existente.

O setor industrial dos produtos de higiene pessoal, perfumaria e cosméticos é composto por diversos segmentos, formado, principalmente, por produtos de maquiagem, cuidado com os cabelos e a pele, perfumaria, desodorantes, depilatórios, produtos para banho, higiene oral, preparados para as unhas, produtos para barbear e de proteção solar, entre outros. Além disso, envolve indústrias de diferentes portes, que vão desde micro, pequenas e médias até os grupos líderes. Desse modo, destacam-se indústrias de 
processamento de matérias-primas, insumos e/ou produtos acabados, como também, as que desenvolvem todas as etapas de produção até a comercialização final nos mercados consumidores.

Como tendência geral no curso das mudanças globais, do "desenvolvimento sustentável" e da valorização dos recursos naturais, os setores industriais tem procurado reduzir os impactos ambientais e o uso de recursos não renováveis, como também, internalizar processos produtivos mais adequados nesse concorrido setor industrial. Para tanto, tem investido na substituição de matérias-primas, alterado os processos de produção e 0 aspecto mais destacável é a da intensa atividade de Pesquisa e Desenvolvimento (P\&D) nas diversas etapas da cadeia produtiva, isto é, desde as etapas de cultivo das matérias-primas, do desenvolvimento de produtos (naturais) e processos até a crescente regulação dos padrões de qualidade e de certificação exigidos atualmente no mercado final. No caso da indústria de cosméticos, os esforços da competência científica têm sido determinantes para o desenvolvimento de produtos inovadores e diferenciados, o que certamente os principais "players" desse estratégico setor disponibilizam.

Diante do exposto, uma das indagações que nos desperta a atenção, diz respeito aos processos de desenvolvimento e incorporação de produtos naturais ou bioprodutos nas indústrias de cosméticos tanto no contexto internacional como no mercado brasileiro. De que modo esse setor industrial tem utilizado as novas tecnologias e a informação dos recursos da biodiversidade como fonte para o desenvolvimento de produtos inovadores? Como esses processos se desenvolvem no território brasileiro e nos centros mais dinâmicos que participam da cadeia produtiva dos cosméticos? Quais são as tendências dominantes do mercado e como a indústria tem incorporado os 
novos ativos em suas estratégias produtivas? O Brasil, como um dos líderes no mercado de consumo de produtos cosméticos em geral e rico em biodiversidade, deverá enfrentar quais desafios desse estratégico setor industrial?

Desse modo, este trabalho trata de conhecer e examinar as experiências no desenvolvimento de cosméticos derivados de ativos da biodiversidade vegetal, visando compreender as principais dinâmicas industriais, econômicas e territoriais desse setor atualmente.

A presente tese se divide em quatro capítulos. No primeiro capítulo, intitulado "Indústria da Beleza", dedicamo-nos a uma breve reconstituição histórica dos principais elementos norteadores e formadores dessa indústria em diferentes períodos, detalhando os aspectos marcantes da valorização do uso de cosméticos, assim como as dinâmicas e tendências que orientam o mercado de consumo na atualidade. Tendo como ponto de partida 0 crescimento dos mercados para os bioprodutos, apresentamos uma abordagem sobre os principais mecanismos de valorização dos recursos naturais e do uso da biodiversidade no estratégico setor de cosméticos.

No segundo capítulo, caracterizamos o panorama geral da indústria de produtos de higiene, perfumes e cosméticos e os principais agentes que atuam nesse setor, como também a atual dinâmica em torno do mercado de consumo mundial e no Brasil, enfatizando os fluxos comerciais entre os países líderes no comércio internacional de óleos essenciais e produtos acabados, e ainda espacializando os conjuntos mais significativos desses circuitos. Apresentamos também as indústrias mais representativas do setor de cosméticos tanto no mundo como no Brasil (com destaque para o estado de São Paulo), selecionando o grupo líder de indústrias mundiais que desenvolvem e exportam 
produtos finais e/ou insumos, além de abordar os aspectos convencionais relevantes à competitividade do setor, como diversificação de mercado, diferenciação de produtos, marketing, entre outros. Nesse capítulo, também avaliamos como o setor industrial de cosméticos tem acompanhado as novas normas estabelecidas pelos diversos mecanismos de regulação, sobretudo as Resoluções específicas da ANVISA, atentando especialmente à questão dos procedimentos burocráticos e técnicos, aí incluídos a necessidade de testes químicos e toxicológicos diversos para a liberação dos produtos nos mercados nacional e principalmente internacional.

O terceiro capítulo, "Os Circuitos de Inovação dos Cosméticos: desenvolvimento de novos produtos e processos industriais", abordamos os aspectos teóricos e debates centrais sobre o papel das novas tecnologias e da inovação no uso da biodiversidade como fonte de informação estratégica para o desenvolvimento de produtos e processos altamente avançados. Além disso, destacamos como se desenvolvem e se articulam as atividades de P\&D e inovação de processos e produtos com ativos naturais na indústria de cosméticos, bem como, as atividades complementares das universidades, dos institutos e grupos de pesquisa nessa área. Esse quadro é examinado mediante os investimentos em processos e produtos inovadores, os impactos da inovação na comercialização dos produtos, contribuições ao crescimento, competitividade e faturamento das empresas. Além do mais, analisamos os principais aspectos legais sobre a bioprospecção no Brasil, bem como a regulamentação do acesso aos recursos genéticos e ao conhecimento tradicional associado (CTA).

Por fim, no quarto capítulo, centramo-nos na identificação das principais etapas da cadeia produtiva dos biocosméticos, desde a produção das matérias- 
primas, destacando a cadeia de "retaguarda", isto é, a origem das principais matérias-primas utilizadas nos produtos cosméticos com ativos naturais; onde estão e quem são os atores responsáveis por essa produção, cultivo, coleta e/ou extração das matérias-primas. Posteriormente, focamos na análise do contexto internacional acerca do desenvolvimento de cosméticos naturais, entre os quais, destacam-se a indústria francesa e as experiências na região de Provence-Alpes-Cotê D’Azur, lócus do segmento de biocosméticos naquele país. Apresentamos também o grupo de indústrias brasileiras consideradas significativas para análise dos processos que definem o nosso objeto de estudo, sendo que algumas delas aparecem como o grande laboratório da diversidade que caracteriza o setor dos cosméticos e, localizam-se, sobretudo na região metropolitana de São Paulo e em municípios do interior do estado. Além do mais, damos especial destaque para a bioindústria de insumos e produtos acabados na Amazônia brasileira, que nos permite conhecer e analisar as atividades produtivas das empresas que ali estão instaladas e que possuem comprovada relação com os segmentos industriais de outras partes do país (inclusive São Paulo) e do exterior.

Neste trabalho, organizamos os dados em torno de uma hierarquia de cenários, isto é, dos aspectos gerais aos setoriais/específicos, e da escala internacional à escala do país, do país às escalas das regiões, subregiões e as principais articulações locais. Para tanto, a interpretação e as análises desses processos foram feitas segundo o levantamento, a organização e a análise detalhada das informações de origem primária obtidas nos trabalhos de campo, dos indicadores de desempenho utilizados na área, do conjunto de dados estatísticos secundários disponíveis sobre o setor de cosméticos no mundo e no Brasil e das pesquisas e estudos desenvolvidos por especialistas de 
diversas áreas do conhecimento, complementados também com as nossas próprias reflexões.

No que se refere à constituição da indústria da beleza e da valorização da biodiversidade, recorremos a diversos estudos, enfatizando, sobretudo, aqueles trabalhos acerca dos mercados de consumo (Bauman, Z.; Lipovetsky, G.; Baudrillard, J., entre outros), como da importância da variável ambiental no cenário contemporâneo (Sachs,I., Ribeiro, W. C.; Leff, E.) e os mercados de consumo de produtos naturais/verdes (Portilho, M. F. F; Layrargues, P. P.).

A respeito dos setores industriais, levantamos informações a partir das empresas selecionadas e das principais entidades empresariais, entre elas, ABHIPEC, ABDI e SEBRAE, das agências e instituições internacionais selecionadas, como a EUROMONITOR e a EUROSTAT, e de outros trabalhos técnicos e acadêmicos (teses e dissertações). Quanto às questões que envolvem a normatização e regulamentação dos produtos e processos industriais da cadeia produtiva dos cosméticos, bem como as legislações específicas sobre o tema, elas foram analisadas, sobretudo em documentos normativos disponíveis nos principais órgãos e agências nacionais (ANVISA) e internacionais (FDA e COLIPA).

No que se refere ao tema das novas tecnologias como núcleo central de valorização da biodiversidade e dos espaços para o uso industrial, científico e tecnológico, consideramos, principalmente, os estudos desenvolvidos por Santos, M., Albagli, S.; Castells, M., Dicken, P.; Costa, W. M.; Becker, B. K., entre outros, e às questões que envolvem a inovação e P\&D na indústria de cosméticos, levantamos os trabalhos e dados específicos do setor em diversas fontes. 
Ao pesquisar sobre o desenvolvimento de produtos com base em ativos naturais, resgatamos o atual debate sobre os sistemas produtivos de base tecnológica (COSTA, W. M.,; BECKER, B, K.), como é o caso da indústria de cosméticos e as diversas expressões da sua territorialização. Tivemos particular preocupação com as informações, indicações e tendências que nos permitiram alcançar tanto as avaliações quantitativas quanto as qualitativas dos padrões de funcionamento, dos processos dominantes e das mudanças em curso.

Buscando ilustrar empiricamente o quadro atual e as tendências do desenvolvimento de produtos cosméticos baseados em ativos naturais, foram realizados trabalhos de campo na região metropolitana de São Paulo e na região de Provence-Alpes-Cotê D'Azur, França. No entanto, salientamos que as visitas e entrevistas foram realizadas somente em um pequeno grupo de indústrias devido à inacessibilidade das empresas para a realização dessa etapa de pesquisa. Desse modo, os trabalhos de campo foram complementados mediante pesquisas de indicadores estatísticos, trabalhos acadêmicos, estudos técnicos disponíveis em instituições, como o MDIC, MCT, FINEP, ABDI, IBGE e EMBRAPA, nos quais reunimos outros materiais sobre o tema, bem como, um nível de detalhamento das informações do segmento estudado. 


\section{CAPÍTULO 1 - A INDÚSTRIA DA BELEZA}

A busca pela beleza parece ocupar um lugar preponderante nos mais diversos âmbitos da vida humana. Ela abrange um conjunto de ideais e padrões estéticos formados em diferentes períodos históricos e por distintas sociedades e culturas. É preciso atentar que esses padrões incorporam valores e conceitos construídos ao longo do tempo, como dos lugares, e são continuamente (re)configurados até assumirem os significados atuais.

Os debates sobre o conceito de beleza, muito embora estejam associados à aparência física das pessoas, nos revelam outros diversos aspectos da vida cotidiana, podendo estar fortemente conectados com 0 universo das artes, da arquitetura, do design, com as características de uma paisagem ou ambiente, podem também estar relacionados a um objeto que contemplamos ou a um fenômeno que nos agrade, como também em muitos outros elementos físicos, simbólicos e até mesmo divinos e espirituais.

A importância designada à aparência do rosto, do corpo e dos cabelos (especialmente a feminina), a valorização da imagem, o culto de atributos corporais específicos, dentre outros, são alguns dos inúmeros reflexos produzidos pela indústria da beleza. Os cuidados com a aparência física representam diversas formas e tipos de comportamentos socioculturais e ao mesmo tempo revelam-se como importantes fios condutores de segmentos ligados direta ou indiretamente a essa indústria. Tais comportamentos têm sido refletidos visivelmente no aumento do consumo de produtos cosméticos, sobretudo nas últimas décadas, e desse modo têm influído claramente no crescimento da indústria de higiene pessoal, perfumaria e cosméticos, assim como nos serviços e setores transversais. 
Neste capítulo, nos preocupamos em conhecer os traços mais marcantes da indústria da beleza, destacando as relações existentes entre os conceitos de beleza e o uso dos cosméticos ao longo da história e dos lugares, como também, os principais mecanismos de construção de uma "indústria da beleza", detalhando os aspectos marcantes sobre a valorização dos produtos cosméticos, a preocupação dada aos cuidados com a aparência e as tendências que orientam o mercado de consumo na atualidade.

\subsection{A Constituição da Indústria da Beleza}

Dentre os estudos a respeito, merece destaque o de Umberto Eco (2004) sobre a história da beleza, tomando por base um extenso panorama das manifestações estéticas registradas nas culturas ocidentais e privilegiando a estreita relação entre a beleza e o feminino. É preciso reconhecer, entretanto, que parte relevante das descrições contempladas por esse autor abrange um sentido amplo das concepções construídas acerca da beleza, integrando assim

diversas faces desse universo e envolvendo temas não apenas ligados à aparência, como também às artes, literatura, arquitetura, entre outros.

Inicialmente, Eco (2004) ressalta em sua análise, a proposta de Pitágoras formulada ainda no século VI a.C., que identificou uma visão estético-matemática da beleza baseada em aspectos de harmonia, simetria, proporcionalidade e racionalidade. Para Pitágoras, "todas as coisas existem porque refletem uma ordem e são ordenadas porque nelas se realizam leis matemáticas que são ao mesmo tempo condição de existência e de Beleza" (idem, p. 61). Outra concepção formulada séculos mais tarde parte de Platão, que desenvolveu a concepção de beleza sob duas égides: na primeira, 
igualmente à visão de Pitágoras, a beleza era vista como harmonia e proporção das partes; na segunda, que influenciaria o pensamento neoplatônico posteriormente, a beleza era tida como algo superior, como esplendor, ou seja, não era o que se via e nem estava presa a um suporte físico corporal.

Mais adiante, a ideia de proporção também foi transmitida à Idade Média, mas no decorrer desse período a beleza espiritual se sobressaiu e os atributos mais valorizados por aquelas sociedades baseavam-se em um discurso religioso, sendo o espírito e o corpo partes integrantes de um sistema "cósmico". Na Idade Média madura, a beleza deveria reunir pelo menos três atributos: a proporção, a integridade, a clareza e a luminosidade, diferentemente da imagem obscura que muitos fazem dessa época, identificada como a "idade das trevas" (ECO, U., 2004). Nessa mesma fase, o gosto pela limpeza e os hábitos de toalete pessoal tornavam-se cada vez mais presentes, notadamente nas classes sociais dominantes, conforme apontada na minuciosa obra sobre a História da Vida Privada: da Europa Feudal à Renascença, dirigida por Philippe Ariès e Georges Duby (2009).

No século $\mathrm{XI}$, a imagem da beleza estava associada à pureza, castidade e ao sagrado e, ainda, relacionada ao pensamento teocêntrico que foi amplamente difundido no período feudal, cujos valores manifestavam-se em Deus como o centro do universo. Segundo Eco (2004), nessa época também teve início a poesia dos trovadores, os romances cavalheirescos e os stilnovistas italianos e "em todos estes textos desenvolve-se uma imagem particular da mulher. Como objeto de amor casto e sublimado, desejada, mas inatingível e muitas vezes desejada por ser inatingível" (idem, p. 161).

Já na fase do Renascimento, aproximadamente entre fins do século XIII e meados do século $\mathrm{XVI}$, foram retomados os ideais de Platão, sob o 
movimento denominado neoplatonismo, que propôs a beleza não mais como proporção e harmonia, mas mediante um sistema simbólico (imagens de Vênus, por exemplo), de aparência discordante, de contemplação da beleza suprassensível, entre a invenção e imitação da natureza. O Renascimento remeteu um período de atividade para as mulheres da corte, que difundiam a moda e os cuidados cosméticos, especialmente dos cabelos pintados de louros e muitas vezes tendendo aos ruivos (idem). Foi nesse período que a beleza feminina atingiu uma posição de supremacia em relação à beleza masculina (RIOS, M., 2010). Jacques Revel (2009) ainda afirma que naquele momento:

"os estilos de vida da sociedade cortesã já não poderiam confinar-se à intimidade de um reconhecimento cúmplice. A corte faz da aparência sua regra social. O respeito à etiqueta, à vestimenta, à palavra, à apresentação do corpo obedece a essa mesma exigência de um reconhecimento coletivo. $O$ perfume, o pó, a peruca produzem um corpo enfim conforme às expectativas do olhar social" (idem, p. 197 e 198)

Posteriormente, no século XVII, a beleza transmite a ideia de escuridão e traz consigo um sentido trágico, sendo a morte a fonte sublime do amor e não mais a paixão. Ao mesmo tempo, renovado pelo Renascimento e pela Reforma Protestante, surgia uma mentalidade antagônica, realizada pela contradição e dualidade do período, exprimindo uma beleza além do bem e do mal e vinculante ao século barroco, na qual se conflitavam valores como: "bem/mal, Deus/diabo, céu/terra, pureza/pecado/, alegria/tristeza e espírito/carne" (RIOS, M., 2010, p. 19). 
No século XVIII, o debate estético apresentava fortes traços de subjetividade, um espaço voltado para a beleza vaga e dos aspectos indetermináveis do gosto e, ainda, marca o aparecimento da mulher na cena pública. Já na segunda metade do século XIX, o conceito de beleza feminina refletia a beleza "inatural", idealizada e artificial, baseada principalmente no uso de artifícios e ornamentos, como joias e adereços. A fase entre os movimentos de 1948 até à crise econômica do final daquele século marcaram o que os historiadores denominaram de a "idade da burguesia", do início da urbanização, do surgimento de novas classes, do mundo industrial e do triunfo da máquina (ECO, U., 2004), esse foi o momento de ostentar e mostrar diferenciação (RIOS, M., 2010).

De um lado, o século $\mathrm{XX}$ refletiu os ideais estéticos propostos pelos vários movimentos de vanguarda e experimentalismo artístico, sobretudo até os anos sessenta daquele século, rompendo com quaisquer modelos estéticos seguidos anteriormente. Esse novo olhar ecoava uma visão moderna do mundo e contemplava não mais as formas harmônicas, mas uma beleza provocativa, exótica, de sonhos e fantasia. Contrastando com essa visão, os meios de comunicação e o mass media produziram padrões de moda e ideais de beleza guiados evidentemente por uma cultura do consumo, sobretudo de grandes marcas, e rotulados por Humberto Eco de "beleza do consumo". Por sua vez, essa fase iniciada no século $X X$, também expressa, ao mesmo tempo, vários ideais estéticos e não apenas um modelo único, seria o "politeísmo da beleza" (ECO, U., 2004), sendo as contradições facilmente visualizadas nos dias atuais.

É nesse sentido que determinados padrões de beleza, sejam eles apresentados sob a forma de simetria, proporção, harmonia, cor ou textura, são 
estimulados ou reforçados por elementos sociais e culturais próprios de cada época e lugar. "Trata-se, portanto, muito mais de uma representação cultural do que propriamente natural (...) para se aproximar dessa idealização, própria de cada época e local, o ser humano sempre fez uso de diversos recursos, encontrados na natureza ou mesmo desenvolvidos, que pudessem aproximar seu corpo natural de seu corpo social e cultural desejado" (RIOS, M., 2010: 21).

Desse modo, os produtos de beleza surgem com a finalidade de modificação, melhoria, correção e/ou disfarce da aparência humana, sendo o termo 'cosmético' derivado do grego kosmetikó, que significa o 'que serve para ornamentar, adornar, enfeitar ou embelezar' (GALEMBECK, F.; CSORDAS, Y., 2009). No Brasil, os cosméticos, produtos de higiene e perfumes são definidos pela ANVISA (Agência Nacional de Vigilância Sanitária) como:

"preparações constituídas por substâncias naturais ou sintéticas, de uso externo nas diversas partes do corpo humano, pele, sistema capilar, unhas, lábios, órgãos genitais externos, dentes e membranas mucosas da cavidade oral, com o objetivo exclusivo e principal de limpá-los, perfumá-los, alterar sua aparência e ou corrigir odores corporais e ou protegê-los ou mantê-los em bom estado" (ANVISA - RDC no 211/2005).

Historicamente, o primeiro registro do uso do cosmético data de 4 mil anos a.C. com a descoberta de um pó avermelhado utilizado no rosto como camuflagem e posteriormente como forma de adoração aos deuses. Mais adiante, os cosméticos foram registrados no antigo Egito, entre 3.100 a 2.907 
a.C., com a existência de uma tintura obtida das folhas da Henna - árvore típica da Índia e do norte do continente Africano - para colorir os lábios e as unhas de vermelho, como também um pó colorido para colorir as pálpebras e um delineador com mistura de carvão e óleo vegetal ou gordura animal, denominado Khol, para ser aplicado na parte inferior dos olhos tanto no embelezamento, como no combate às infecções características daquela época (RIOS, M. H. V., 2010). Além disso, os registros apontam que os egípcios pintavam os olhos com sais de antimônio com o objetivo de evitar a contemplação direta do Deus Ra (sol) e usavam gordura animal e vegetal, cera de abelhas, mel e leite como cremes para a proteção da pele contra as altas temperaturas do clima desértico (GALEMBECK, F.; CSORDAS, Y., 2009).

Além desses indícios, também foi apontado o uso de cosméticos originados de rochas vulcânicas porosas para a limpeza dos dentes em meados do século I a.C. com os Romanos. Azeite e óleo de pinho eram utilizados pelos gregos e romanos na produção de sabões. Além disso, pastas eram elaboradas com óleos e pigmentos naturais de extratos de açafrão e mostarda por atores romanos para serem aplicadas como maquiagem (idem).

Já na Idade Média, os hábitos observados nos países orientais pelas expedições das cruzadas medievais foram reproduzidos na Europa e, sobretudo, nas elites dominantes daquele período. Posteriormente, no século $\mathrm{XIX}$, as pesquisas sobre os produtos de beleza se intensificaram principalmente na França com o desenvolvimento de estudos sobre novos ingredientes e assim o uso dos cosméticos foram sendo cada vez mais difundidos (ROSA, I. L. V., 2006). No que diz respeito aos cuidados com 0 corpo e higiene, Revel (2009) descreve que: 
"do final da Idade Média a meados do século XVIII, a limpeza, tal como nossos tratados em particular a ilustram, em geral dispensa a água e ignora o corpo, à exceção do rosto e das mãos, que são as únicas partes expostas. Os cuidados concentram-se no visível (...) Assim, a toalete deve ser "seca"; consiste em friccionar-se e perfumar-se; (...) nas décadas de 1740-50, a água — quente, depois fria — torna-se sem dúvida o indício de novas distinções sociais; porém ao mesmo tempo insere-se numa nova imagem do corpo que ultrapassa o savoirvivre: a higiene reabilita a intimidade corporal e legitima a procura de uma melhor utilização dos recursos orgânicos. Enfocada pela medicina e depois levada às escolas, logo se tornará, aliás, o dispositivo inédito de uma nova forma de controle coletivo dos comportamentos." (idem, p. 192)

Há que se destacar também que muitos cosméticos são elaborados até hoje artesanalmente a partir do uso de ingredientes caseiros. Muitas das receitas formuladas incluem diversos componentes, em especial, ervas aromáticas, óleos e outros diferentes tipos de vegetais.

Gilles Lipovetsky (2000) ressalta que o uso de produtos de beleza e os cuidados estéticos deixaram de ser exclusivos das classes dominantes apenas no século XX, iniciando-se, dessa forma, o que denominou de "uma era democrática da beleza". O consumo de produtos cosméticos apresentou significativo crescimento a partir dos anos 1920 e 1930, quando o batom, os bronzeadores e esmaltes ganharam destaque entre o público feminino. Esse fenômeno teve estreita relação com a intensificação da urbanização e com as 
mudanças de hábitos vinculados a melhoria do saneamento básico, condições de saúde e higiene. O autor descreve que:

"O consumo de cosméticos aumenta moderadamente até a primeira Grande Guerra e se acelera nos anos 20 e 30.0 batom fez um imenso sucesso a partir de 1918 e os bronzeadores e esmaltes de unha fizeram furor nos anos 30 . Em razão dos progressos científicos, os métodos industriais, a elevação do nível de vida, os produtos de beleza tornaram-se, em nossas sociedades, artigos de consumo corrente, um 'luxo' ao alcance de todos" (idem, p.131).

Em meados do século $X X$, iniciou-se um novo ciclo envolvendo os cuidados e práticas de beleza, no qual o desenvolvimento de uma cultura de consumo, influenciada pelos meios de comunicação (sobretudo da televisão) e por uma nova dinâmica baseada na produção industrial de bens de consumo de uma série de empresas que começaram a surgir, culminou também na democratização dos produtos de beleza, adentrando na vida cotidiana em grande escala. É neste panorama que Lipovetsky (2000) identifica alguns dos principais limites que configuram a indústria da beleza: "depois do ciclo elitista, o momento democrático; depois do ciclo artesanal, a época industrial; depois do período artístico, a era econômico-midiática" (idem, p. 130).

As diferentes formas e usos dos cosméticos, assim como os hábitos construídos ao longo da história refletem um processo contínuo de transformação e evolução da indústria da beleza. De ingredientes simples e tradicionais utilizados ora para pintar, higienizar e/ou nutrir a pele, os 
cosméticos foram modificados e se tornaram, sobretudo nas últimas décadas, produtos sofisticados com diferentes funções e versões conforme sua aplicação e finalidade, produtos de consumo corrente ao alcance de todos.

Atualmente o acesso aos cosméticos tem sido cada vez mais amplo, podendo ser distribuídos por lojas especializadas, farmácias, drogarias, hipermercados, supermercados, websites das marcas ou revendedores da internet, "consultores" de venda direta, dentre outros. Além disso, a indústria da beleza é formada por diferentes agentes, envolvendo desde setores industriais dedicados à fabricação de produtos cosméticos, perfumes e higiene pessoal, até aqueles envolvidos com o cuidado da aparência e do corpo, como os salões de beleza, as clínicas de estética e de cirurgias plásticas, spas e as academias de ginástica.

Diversas opções de produtos para o rosto, os cabelos e o corpo são desenvolvidos para atender as demandas e expectativas dos consumidores, sendo elas pincipalmente ao longo das últimas décadas indicativas de uma preocupação com a juventude e os cuidados em relação ao corpo. Segundo Lipovetsky (2000), o momento que passamos é o da "anti-idade e do antipeso", sendo a prevenção e os cuidados com o rejuvenescimento, a tonificação e o fortalecimento da pele imprescindíveis na busca pela beleza. Sem dúvida, os cuidados com o corpo que associam saúde e beleza não são fenômenos estritamente recentes, uma vez que em períodos anteriores também foram observadas preocupações com esses aspectos. Entretanto, a ideia de que as pessoas devem manter-se belas, jovens e saudáveis tem sido um dos comportamentos dominantes na atualidade. Palacios (2006) destaca que "embora seja ancestral o inconformismo do homem frente ao processo de envelhecimento, a busca pela manutenção da juventude pode ser 
compreendida como um dos emblemas da cultura contemporânea" (PALACIOS, A., 2006: 3 e 4).

Nas últimas décadas, beleza, juventude e bem-estar ocupam posição privilegiada na "indústria da vaidade", sendo os cosméticos considerados os produtos capazes de integrar tais dimensões e satisfazer essas aspirações. Castro (2003) reforça que esses aspectos associados com a higiene pessoal têm sentidos entrelaçados, resultado do modo como foram incorporados nas práticas cotidianas e passaram a compor o universo vocabular. As ações das políticas de saúde pública da primeira metade do século $X X$ difundiram alguns itens de higiene e limpeza, dentre eles, os sabões e os sabonetes, como produtos fundamentais para a manutenção de uma vida saudável. Segundo a autora:

"As doenças infecciosas são vistas como um perigo que atravessa todas as classes e a melhor forma de combatê-lo são as práticas higiênicas agora tão difundidas pelos médicos e sanitaristas e que têm no sabão um componente fundamental. Os publicitários não tardaram a associar o apelo higienista ao estético, colocando estrelas de cinema como protagonistas de anúncios de sabonete e, a reboque, de creme, batom, rouge, pó-de-arroz, ou seja, de todo produto que possibilitasse a reparação de pequenos defeitos (cosméticos) e a manutenção da higiene (sabões e sabonetes), garantidores de uma vida saudável. Vende-se a idéia [sic] de que sabão deixa a pele mais limpa e, portanto, mais saudável, logo, mais bonita" (idem, p. 85). 
Refletir sobre os cuidados com o corpo e a busca pela beleza passa, certamente, pela esfera da sociedade de consumo (BAUDRILLARD, J., 2007; LIPOVETSKY, G., 2007). Para Lipovetsky, os indivíduos são informados sobre o que pode e deve ser consumido ou praticado e, desse modo, não se enquadram nos padrões de comportamento e hábitos de consumo se não quiserem. A esse respeito, Zygmunt Bauman (2008) reforça a ideia de que "na era da informação a invisibilidade é equivalente à morte" (idem, p. 21) e, desse modo, as pessoas procuram sempre se destacar, diferenciando-se por meio de seus hábitos e comportamento. Ademais, Baudrillard ressalta que "à nossa volta, existe hoje uma espécie de evidência fantástica do consumo e da abundância, criada pela multiplicação dos objetos, dos serviços, dos bens materiais, originando como que uma categoria de mutação fundamental na ecologia da espécie humana." (idem, 2007: 15). Quanto à intensa aceleração e difusão dos signos, Antas Jr (2007) defende que:

"há uma tendência de relativa homogeneização na elaboração dos objetos técnicos, dos processos e dos serviços para ampliar as escalas de comércio das empresas, verifica-se que essa capacidade de condicionamentos tem se expandido em várias regiões do planeta, como em várias regiões brasileiras" (idem, p. 101).

Além disso, outra tendência em curso diz respeito ao uso de insumos naturais nos produtos cosméticos, indicando um novo nicho de mercado que se encontra em plena expansão, sobretudo nos mercados já consolidados da 
União Europeia e EUA e com grande potencial de crescimento nos países da América Latina. Os cosméticos com ativos naturais e certificados sob os critérios da sustentabilidade representam umas das tendências mais recentes do setor. Os produtos formulados com ingredientes naturais têm incorporado diferentes valores e conceitos, atribuídos a uma sociedade que cada vez mais valoriza um estilo de vida saudável, a aparência, o bem-estar e que se preocupa com as questões ambientais. Assim "comportamentos preventivos em relação à saúde do corpo se estendem em âmbito global, inspirando cuidados com o meio ambiente e o planeta como um todo", divulgando-se também nos meios de comunicação "o aumento dos problemas ambientais, dos desastres ecológicos, do surgimento de doenças e epidemias, como consequências naturais e das próprias atitudes humanas" (RIOS, M., 2010: 31 e 32).

É nesse panorama que a indústria de cosméticos ingressa com empenho na disputa para o lançamento de novidades e no desenvolvimento de produtos com novos ingredientes baseados em novas tecnologias, utilizandose também dos artifícios da publicidade e do marketing para atrair e estimular o uso de cosméticos como mercadorias de primeira necessidade. A seguir apresentamos os principais pilares acerca da expansão do que aqui denominamos de indústria da beleza.

\subsection{Os Novos Pilares da Indústria de Cosméticos: juventude, beleza e bem-estar}

Um ponto de partida para a análise da indústria da beleza e seus novos pilares pode ser atribuído aos significativos avanços do setor quando 
examinado o crescimento global do consumo de produtos de higiene pessoal, cosméticos e perfumes. Em 2011, o crescimento do consumo mundial foi de 9,8\% em relação ao ano anterior, totalizando um faturamento de US\$ 425 bilhões (EUROMONITOR, 2012). Diversos aspectos têm contribuído para a expansão dos "setores da beleza", sendo esse quadro associado, principalmente, aos fenômenos do consumo decorrentes da urbanização e a formação de novos hábitos e comportamentos da sociedade contemporânea; ao aumento da expectativa de vida da população em geral; a maior participação da mulher no mercado de trabalho e que consequentemente tem ampliado seu poder de consumo; à entrada de novas indústrias no setor; à demanda de lançamento de novos produtos; aos crescentes nichos de mercado (por exemplo, do público masculino, da $3^{\underline{a}}$ idade, dos produtos naturais, dentre outros); ao barateamento e à facilidade de acesso aos produtos e serviços; ao aumento da produtividade e à introdução de novas tecnologias, bem como, dos sistemas de P\&D e de inovação tecnológica aplicados especificamente no desenvolvimento de novos bioprodutos e, ainda, da nanotecnologia.

A expansão dessa indústria envolve diferentes fatores que se complementam e se entrelaçam, sendo necessário o detalhamento de alguns dos principais processos que explicam o avanço desse mercado de consumo atualmente. Neste item, optamos por abordar algumas perspectivas teóricas associadas às diversas mudanças na vida cotidiana e que têm refletido no consumo de produtos de beleza. Trataremos com mais ênfase as questões relacionadas à estrutura produtiva e aos avanços tecnológicos da indústria de cosméticos nos capítulos seguintes deste trabalho. 
Um dos aspectos que destacamos quanto ao crescimento do consumo de produtos cosméticos diz respeito às repercussões da expansão da urbanização e dos inúmeros efeitos produzidos por esse fenômeno global. Os processos ocorridos no cenário urbano têm imprimido uma série de transformações nas dinâmicas territoriais, econômicas e sociais, e por sua vez, também têm se refletido na esfera do consumo e no comportamento dos indivíduos. Desde o final da Segunda Guerra o processo de urbanização tem sido intenso em todo o mundo, e no caso do Brasil, essa expansão tem se dado, sobretudo, nas últimas quatro décadas. Em 1970, a população urbana no país somava $55,9 \%$ do seu total de habitantes, passando para $84,0 \%$ em 2010 (IBGE, 2010), e as estimativas da taxa de urbanização brasileira apontam que ela pode chegar a 90\% em 2020 (ONU, 2012).

Desse modo, além das cidades concentrarem cada vez mais habitantes, as aglomerações urbanas e, principalmente as grandes metrópoles e suas regiões metropolitanas, vão imprimindo novos modos de vida, hábitos e padrões culturais e de consumo a essa população. A esse respeito, Fábio Contel (2006) destaca:

"Já que a população do país passa a ser eminentemente urbana [desde ao menos a década de 1970], vale dizer que ela é também, cada vez mais sensível ao que George Simmel [1902, 1976] chamou de "intensificação dos estímulos nervosos" provocada pela vida em grandes cidades. Isto é, os citadinos são mais expostos [pela proximidade física e organizacional] aos novos vetores da modernidade que se dão, par excellence, nos meios urbanos de todo o globo terrestre. $\mathrm{O}$ 
acesso diuturno a novas formas de comunicação [por televisão, rádio, internet, telefones, celulares, etc.] faz chegar às cidades pequenas e médias, mas principalmente nas metrópoles nacionais, uma quantidade inaudita de informações, mensagens e estímulos eletrônicos de toda sorte" (idem, p. 162).

Quanto a isso, o autor ainda explica que "no período atual, as populações urbanas estão cada vez mais expostas a vetores que potencializam as práticas de consumo", dentre eles, "a financeirização da vida cotidiana" dada pela maior acessibilidade ao crédito e a força da publicidade cada vez mais influente na vida urbana (idem, p. 162).

No que se refere à expectativa de vida, observa-se que o aumento da população idosa tem se tornado um fenômeno mundial e promovido uma série de impactos sociais, econômicos e políticos. Segundo os estudos de demografia, o grupo etário acima dos sessenta anos apresenta expressivo crescimento há cerca de quatro décadas, especialmente nos países formados por população majoritariamente jovem (com menos de 15 anos), ocorrendo assim uma crescente substituição desse segmento.

Os limites de idade que distinguem uma população idosa compreendem diferentes critérios, sendo usualmente mais utilizada a definição baseada na Organização Mundial da Saúde (OMS), que define como idoso o indivíduo com 60 anos ou mais (nos países em desenvolvimento) e com 65 anos (nos demais países). No Brasil, considera-se que a velhice tem início com idade igual ou superior a 60 anos, conforme o Estatuto do Idoso/Lei no 10.741/2003. 
O envelhecimento da população é reflexo de diversos fatores, envolvendo, sobretudo, os avanços no campo da saúde com melhorias significativas dos serviços e com grande impacto na vida dos indivíduos, a redução das taxas de fecundidade e mortalidade - principalmente nos centros urbanos, mudanças no mercado de trabalho, aumento da qualidade de vida e das condições sociais, sanitárias, alimentares, ambientais e a manutenção dos cuidados de higiene pessoal, entre outros. Por outro lado, alguns autores apontam que o processo de envelhecimento não é fruto apenas da queda da mortalidade populacional, tendo em vista que "uma população torna-se mais idosa à medida que aumenta a proporção de indivíduos idosos e diminui a proporção de indivíduos mais jovens, ou seja, para que uma determinada população envelheça, é necessário haver também uma menor taxa de fecundidade" (NASRI, F., 2008, p. 4).

A crescente participação da população acima de sessenta anos na composição etária em geral tem sido uma experiência visível ao redor do mundo, mas ainda se encontra em transição, isto é, um processo recente em alguns países. Atualmente, pouco mais de $12 \%$ da população mundial é composta por idosos, reunindo mais de 800 milhões de pessoas nessa faixa etária (ONU, 2011). A Europa, os EUA e o Japão concentram as maiores proporções de idosos há várias décadas, enquanto os países "em desenvolvimento" e emergentes em geral concentram o maior número absoluto de população nesta faixa.

De acordo com os dados da ONU (2011) sobre população, existiam no mundo em 1950 cerca de 250 milhões de pessoas com mais de 60 anos, representando 1\% do total. Apenas China, Índia e EUA agrupavam mais de 82 
milhões de habitantes idosos, ou seja, $32 \%$ da população nessa faixa viviam nesses países naquele ano.

Já em 2010, a faixa etária com mais de 65 anos representava 7,6\% do total, porém não mais centralizada em um pequeno grupo de países. As previsões apontam que essa participação será de 1,9 bilhão em 2050, representando um quinto da população mundial. Nesse contexto, pela primeira vez na história da humanidade a população idosa será mais numerosa do que a de crianças e adolescentes. Além disso, a proporção da população acima de oitenta anos também tem sobressaído nessa composição etária, isto é, verificase um envelhecimento neste próprio grupo populacional (CAMARANO, A. A., 2002).

Outra característica do grupo composto por pessoas acima de sessenta anos diz respeito a importante participação da parcela feminina nessa faixa etária, reflexo da elevada expectativa de vida das mulheres em relação aos homens. Este fenômeno pode ser observado praticamente em todo o mundo e a longevidade feminina está vinculada a diversos fatores, com destaque para os cuidados com a saúde, os estilo de vida, dentre outros.

No Brasil, por exemplo, até o início dos anos 1980, a estrutura etária estava predominantemente marcada por uma população formada por crianças, adolescentes e jovens. Contudo, a queda da natalidade e o aumento da expectativa de vida, assim como a conjunção dos demais fatores citados anteriormente, reforçaram o crescimento de uma população adulta e em idade ativa, favorecendo consequentemente novas dinâmicas de trabalho, renda e consumo em todo o país e notadamente no cenário urbano. As causas para a modificação do padrão reprodutivo também estão associadas ao intenso processo de urbanização, como também ao "modus vivendi" dos grandes 
centros urbanos, à gradual entrada da mulher no mercado de trabalho, às mudanças de padrões socioculturais, dentre outros (VERAS, R. P., 1988: 384).

O acréscimo do contingente idoso no topo da pirâmide etária brasileira tem sido constante e, atualmente, a população com mais de sessenta anos reúne 20.590.597 indivíduos, segundo o último censo demográfico do IBGE realizado em 2010. Em 1950, a proporção da população com mais de sessenta anos no Brasil era de 4,3\% e essa participação foi aumentando ao longo dos períodos analisados, sobretudo desde as últimas três décadas, representando em 2010 quase $11 \%$ no total da população brasileira e 2,7\% da mundial (IBGE, Censo Demográfico 1940-2010). Registre-se, também, que as mulheres constituem 55\% do grupo de idosos. As projeções disponíveis demonstram que o envelhecimento da população no Brasil tende ser cada vez maior e a proporção de idosos em relação à população nacional deverá ultrapassar a média mundial em 2020 (Gráfico 1).

\section{Gráfico 1 - Proporção de População com 60 anos ou mais no} Mundo e no Brasil entre 1950 e 2050

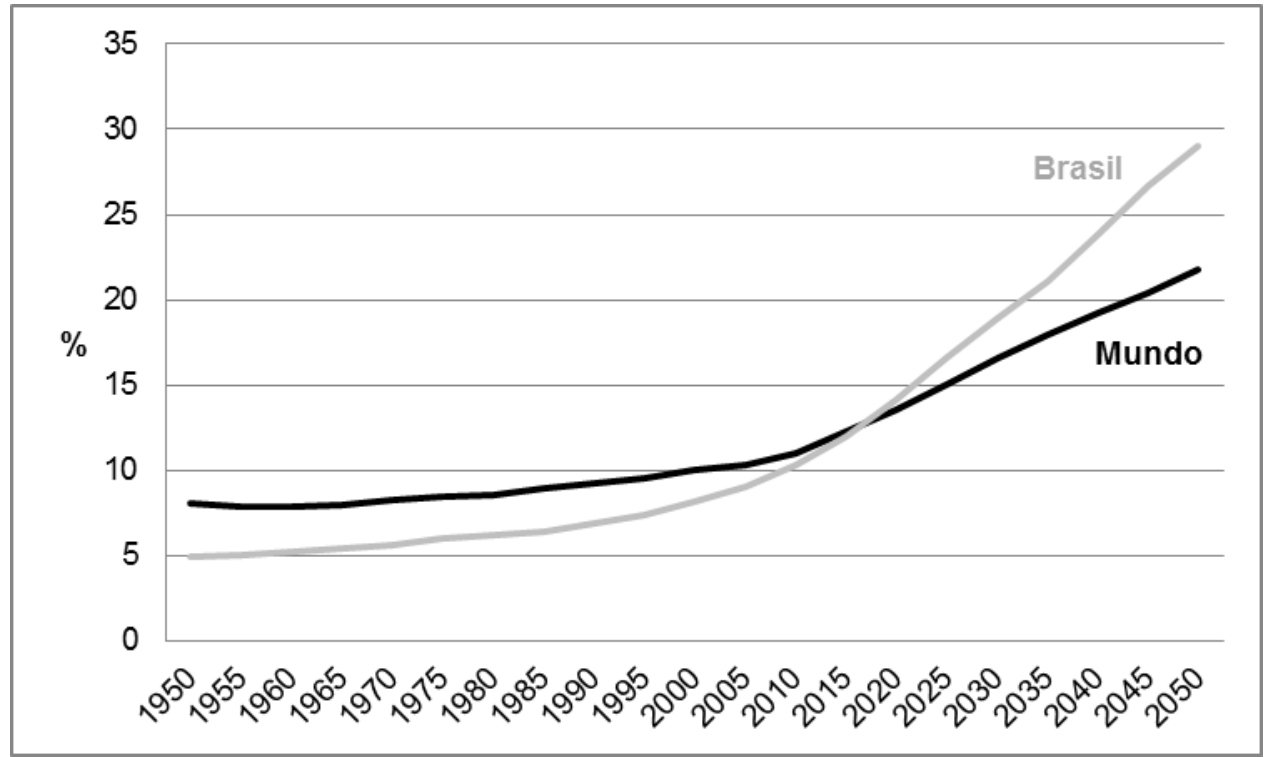

Fonte: Population Division of the Department of Economic and Social Affairs of the United Nations Secretaria, 2010. Elaboração da Autora, 2012. 
No total da população brasileira, o contingente dos "mais idosos" (com idade de 80 anos ou mais) apresenta uma participação pequena se comparado à população total do país, entretanto ele também tem aumentado em ritmo bastante acelerado, ocorrendo dessa forma também um envelhecimento da população idosa. Em 1950, o contingente "mais idoso" era formado por aproximadamente 155 mil pessoas e passou para cerca de 2,9 milhões em 2010, o que representava $14 \%$ da faixa etária idosa (60 anos ou mais) e 1,5\% da população total do Brasil (IBGE, 2012 - Censo Demográfico 1940-2010).

Dentre outros fatores, o processo de envelhecimento populacional tem trazido importantes mudanças nos perfis sociais e impactado diretamente os comportamentos, hábitos de consumo e estilos de vida da população de um modo em geral. Além disso, o aumento da faixa etária idosa, tanto em números absolutos como relativos, traz repercussões importantes em várias esferas.

O crescimento do contingente populacional com idades mais avançadas tem se tornado importante variável na demanda e no consumo de diversos produtos ao passo que com o prolongamento de vida a população tem mais tempo de consumir bens e serviços, dentre eles, os produtos e serviços de cuidados do corpo, da aparência e da saúde. Apesar da população mais velha representar, cada vez mais, importante parcela da população mundial, cabe ressaltar que muitos valores e comportamentos associados à beleza e aos cuidados com o corpo ainda são fortemente baseados por um ideal jovem, parecendo, dessa forma, existir um deslocamento "entre os significados simbólicos que circulam socialmente e a realidade" (RIOS, M., 2010, p. 40). Observamos que neste contexto há uma desvalorização da velhice em face à juventude, no qual o envelhecimento ganha sentido negativo, algo a ser 
evitado, e a juventude remete ao que é novo e algo a ser cultivado. Chama a atenção que diversos termos mais sutis foram surgindo ao longo do tempo para designar a velhice, como terceira idade, fase idosa, melhor idade, fase do amadurecimento, entre outros.

A preocupação com a juventude, sobretudo a feminina, não é um fenômeno recente, porém ao longo das últimas décadas, a supervalorização da aparência jovem tem ganhado cada vez mais força e se tornou um desejo da sociedade em geral e, particularmente, das sociedades ocidentais contemporâneas (LIPOVETSKY, G., 2000). Conforme Debert (1999) destacou: "a juventude perde conexão com um grupo etário específico, deixa de ser um estágio da vida para se transformar em um valor, um bem a ser conquistado em qualquer idade, através da adoção de estilos de vida e formas de consumo adequadas" (DEBERT, G. G., 1999, p. 21).

Embora a insatisfação diante do envelhecimento constituir um comportamento antigo, enfatizamos neste trabalho, os mais recentes e principais processos que levaram à construção de uma preocupação exacerbada com a juventude e sua relação com o crescimento do consumo de produtos cosméticos.

Vemos então a construção de um conjunto de valores e novos comportamentos preventivos visando combater a idade biológica de uma população com expectativa de vida cada vez maior. De acordo com Manuel Castells (1999) isso acontece porque estão ocorrendo mudanças significativas na "relação entre condição social e estágio biológico que fundamenta o ciclo de vida" (CASTELLS, 1999, p. 473). No período atual, observamos de diferentes formas uma busca da sociedade em geral para retardar o envelhecimento e uma enorme cobrança social desse aspecto, "antigamente, uma filha queria 
parecer-se com sua mãe. Atualmente é o contrário que acontece" (LIPOVETSKY, 1989, p. 139 e 140). Conforme apontado por Vianna (1992), essa procura "nega uma afirmação da "natureza" em função de algo que sabemos ser falso - temos plena consciência de que não seremos sempre jovens, apesar da juventude eterna ser apresentada como possível e real" (idem, p. 16).

No decorrer das últimas décadas, a luta e prevenção contra as marcas, rugas e manchas na pele começam desde muito cedo e se prolongam por mais tempo também. A busca pela beleza e cuidados do corpo inicia cada vez mais no auge da própria juventude, sobretudo entre as mulheres que são, habitualmente, a principal clientela-alvo dos produtos e serviços da indústria da vaidade. O público feminino de diferentes classes socioeconômicas e faixas etárias, mas em especial da população adulta e idosa, recorrem a variados tratamentos estéticos, cosméticos e outros recursos médicos e alimentares que anunciam o rejuvenescimento, a reparação e a renovação da pele. Desse modo, os antissinais, anti-idade ou anti-ageing tornaram-se produtos de uso difundido e ao alcance de todos, sendo que "as mulheres adotam uma postura obcecada em busca da juventude, tornando este comportamento algo estruturador e centralizador na construção do ideal de beleza feminina contemporânea" (RIOS, M., 2010, p. 49).

É graças a essas novas tendências de consumo que os produtos de cuidado com a pele tem se sobressaído frente aos demais, fato que pode ser verificado no crescimento constante do faturamento global do setor (Gráfico 2), seguido pelos produtos para cabelo, maquiagem, perfumaria, de higiene oral, banho, produtos para o público masculino, desodorantes, protetores solares, produtos infantis e depilatórios (EUROMONITOR, 2009). 
De todo modo, o fato a destacar nessas tendências é que os produtos anti-idade comandam o mercado global desse segmento líder da indústria de cosméticos. Os cremes, géis, loções e preparados anti-ageing - como também são denominados no setor - são aqueles produtos que apresentam maior valor agregado e inovação em suas fórmulas, sendo responsáveis por mais de $23 \%$ do mercado mundial de produtos de cuidados com a pele (LENNARD, C., 2009).

Gráfico 2 - Distribuição Global do Setor de Cosméticos: crescimento (\%) entre 2007 e 2008 e faturamento em 2008 (US\$ bilhões)

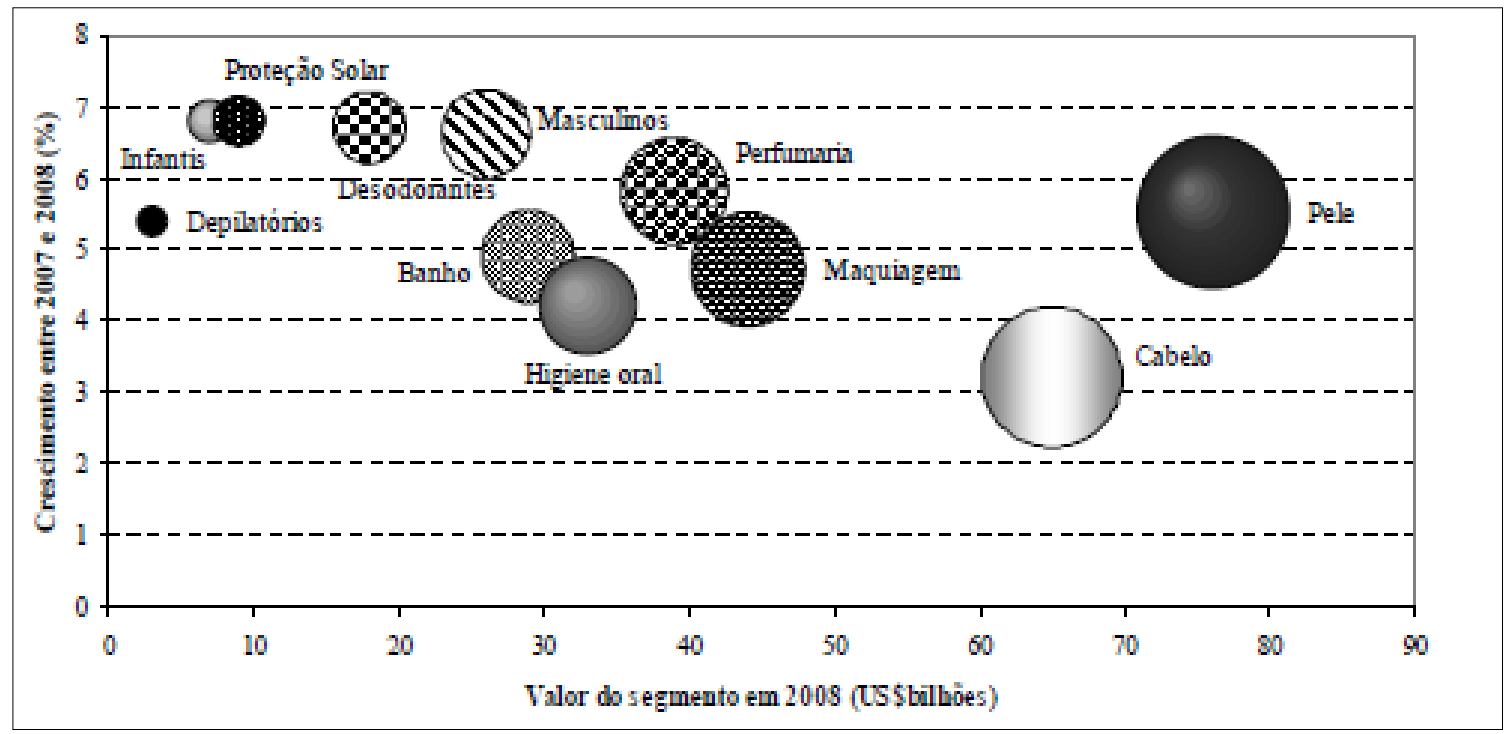

Fonte: Euromonitor, 2009, In: Ferro, 2010.

Entre 2009 e 2010, o mercado mundial de produtos faciais foi ampliado em $4,5 \%$ e englobou mais de $€ 53,7$ bilhões. $O$ crescimento deste segmento tem sido mais significativo na América Latina, que apresentou expansão de $12,5 \%$ nesse período, no entanto o maior mercado é o Asiático, concentrando mais de $48 \%$ do mercado global de produtos para a pele e $35 \%$ dos produtos anti-idade (Gráfico 3).

Cabe destacar que os produtos voltados aos cuidados com a pele nem sempre estiveram à frente na participação do faturamento deste setor industrial 
(COSMMA, 2011). Ao longo da década de 1990, os segmentos considerados como bens de primeira necessidade e comuns, dentre eles, os itens de higiene pessoal, foram perdendo posição para produtos considerados supérfluos, destacando desse modo uma importante transformação no interior e na dinâmica do setor com o crescimento do consumo de produtos dispensáveis e mais sofisticados. Esta tendência é observada praticamente em todo o mundo e caracteriza uma mudança de hábito e comportamento, onde produtos que antes não ocupavam lugar relevante no consumo da população agora têm sido valorizados.

\section{Gráfico 3 - Participação no Consumo de Produtos Anti-idade por grandes regiões em 2010}

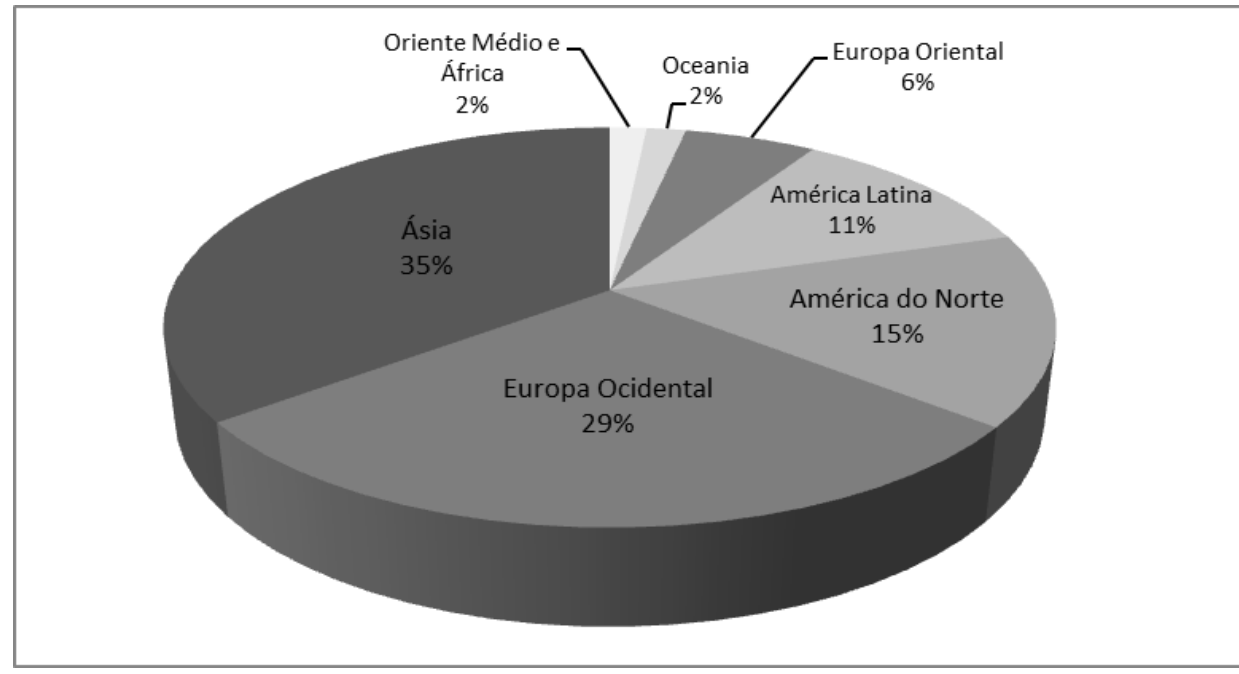

Fonte: COSSMA, 2011. Elaboração da Autora

É nesse contexto de novas tendências de consumo que a indústria de cosméticos direciona suas estratégias de mercado para três eixos principais no período atual: o segmento jovem e de cuidados com a pele, o uso de matériasprimas da biodiversidade e a incorporação da sustentabilidade ambiental. Segundo as agências que representam o setor, as macrotendências globais e nacionais têm procurado incorporar "um novo tempo - buscar o controle da 
vida e reconstruir o mundo em cima de outros eixos" (ABDI; ABIHPEC; SEBRAE Nacional, 2011, p. 7).

Aliadas as estratégias de mercado, as empresas - sobretudo as detentoras de grandes marcas - procuram desenvolver ações abrangentes de marketing, especialmente mediante a publicidade televisiva para tornar cada vez mais atraentes os produtos para o consumidor. Apesar da presumida importância atribuída à juventude, os meios de comunicação também reforçam com frequência que a velhice, mesmo sendo uma questão biológica e natural, pode ser considerada um "estado de espírito" e que pode ser evitada (SANT'ANNA, D. B., 2004). Trata-se de reunir todas as faixas etárias em um grande mercado destinado notadamente ao consumo de produtos que incorporam um estilo de vida ou que preservem a juventude e, dessa forma, garantir mais um mecanismo de consumo em larga escala. Para Vianna (1992), a juventude trata de uma identidade social quando os signos e símbolos são operados no domínio do consumo, desse modo:

"é jovem quem está em evolução, atento à dinâmica mercadológica e aberto às inovações e mudanças e tendências globais. Da mesma maneira a juventude está intimamente associada à idéia (sic) de beleza e cuidados com o corpo, no intuito de dissimular a idade sociobiológica e causar uma impressão de vitalidade" (idem, p. 2).

Os cuidados com o corpo em geral (especialmente a magreza) também têm ocupado lugar extremamente importante no marketing da indústria da beleza. No fim dos anos 1920, a combinação das indústrias de cosméticos, 
moda, publicidade e cinematográfica, em especial de Hollywood, marcou o ideal de magreza naquele momento, porém o prolongou por todo século XX. Essas indústrias influenciaram intensamente o uso da maquiagem, como também refletiram diretamente na valorização de um ideal físico voltado para o corpo esbelto, magro e esguio (FEATHERSTONE, M., 1993). Já em meados do século $\mathrm{XX}$, as práticas corporais com intenção de estética deixaram de se manifestar como uma experiência provisória e de atividades realizadas apenas por determinadas idades. Castro (2001) diz que:

"A preocupação com o corpo esbelto - sinônimo de corpo saudável - na contemporaneidade pode ser compreendida como algo que diz respeito à condição do indivíduo na modernidade. A ambientação urbano-industrial dos anos 20 representa um importante marco histórico para a compreensão do processo no qual a corporeidade ganha evidência cada vez maior" (idem, p. 16 e 17).

Nos dias atuais, a preocupação de manter o corpo esbelto e atraente tem refletido diretamente no aumento do número de academias de ginástica, especialmente nos grandes centros urbanos. De acordo com entidades do setor, este expandiu no país mais de 100\% nos últimos anos, passando de sete mil estabelecimentos em 2004 para 18.000 em 2012, e colocando o Brasil na segunda posição mundial, perdendo apenas para os Estados Unidos (ACAD, 2012). Michel Maffesoli (1996) considera que os cuidados com a aparência e a forma do corpo não são "de modo algum, um fato individual ou narcísico, mas, 
muito pelo contrário, um fenômeno global, ou, mais exatamente, a cristalização no nível da pessoa (persona) de um ambiente de todo coletivo" (idem, p.53).

Como consequência das tendências dominantes observadas com 0 crescimento de determinados nichos de mercado, encontramos atualmente um arsenal de produtos e serviços, milhares de tratamentos e produtos da indústria da beleza, como antioxidantes, colágenos, ácidos retinóicos, glicólicos, peeling e botox, e que são de modo geral anunciados como fórmulas milagrosas. Como visto, a tendência atual do consumo desses produtos se manifesta especialmente em torno da aparência, notando-se um desejo de adiar ao máximo as manifestações próprias do envelhecimento.

Lipovetsky (2007) aponta que nos últimos trinta anos esse fenômeno tem se fortalecido e agora é o tempo do consumo desenfreado do novo e de uma enorme preocupação pessoal com o prazer, o bem-estar e a saúde. Dessa maneira, o consumo se desloca da esfera meramente mecânica da compra indiscriminada de mercadorias para o âmbito do bem-estar, da saúde, do cuidado e da prevenção, não se vendendo meramente apenas mais um produto, mas um conceito e um estilo de vida. Para o autor, os cuidados com a saúde estão cada vez mais onipresentes, seria a "medicalização do consumo":

"a competência médica estende-se a todos os domínios da vida para melhorar-Ihes a qualidade. Enquanto um número crescente de atividades e de esferas da existência toma uma coloração sanitária, os bens de consumo integram cada vez mais a dimensão da saúde: alimentos, turismo, habitat, cosméticos, a temática da saúde tornou-se um argumento decisivo de venda" (idem, p. 53 e 54). 
Ao mesmo tempo em que os meios de comunicação têm promovido maior acesso e disponibilidade de informações, eles também traçam tendências e divulgam "manuais" de boas práticas, veiculando modelos de comportamento, estilos de vida e incentivando hábitos para a sociedade em geral. Além disso, no universo da indústria da beleza, criou-se um discurso que busca unir argumentos estéticos e técnicos, ou seja, se você se tornar bela (o) e atraente, consequentemente poderá usufruir de uma vida saudável, sentirse bem, ter sucesso profissionalmente, etc.

A atenção com a beleza da pele, cuidados com o corpo e o cabelo, alimentação balanceada, modelamento e rejuvenescimento do corpo, uso de cosméticos, medicamentos e até mesmo intervenções cirúrgicas estão cada vez mais presentes na vida cotidiana dos indivíduos e são amplamente explorados nos meios de comunicação, tanto impressos como eletrônicos. Há algumas décadas, as cirurgias estéticas estiveram normalmente associadas a casos de reparação ou melhora de defeitos congênitos ou adquiridos, como lesões severas causadas por queimaduras ou cicatrizes, contudo se transformou num instrumento legítimo de rejuvenescimento, embelezamento e de eterna reconstrução de corpos e rostos. Neste quesito, o Brasil também compõe o grupo dos países líderes em intervenções estéticas, ocupando a segunda posição em todo o mundo no que se refere a cirurgias plásticas, totalizando mais de 1.5 milhão de procedimentos em 2010 (Anexo 1). A propósito, o tipo de procedimento mais realizado no país é a lipoaspiração (representa $20 \%$ do total mundial), em seguida o implante de prótese de silicone nos seios, as cirurgias na pálpebra e no abdômen (ISAPS, 2010), ou seja, abrangem em sua maioria os procedimentos estéticos relacionados à beleza. 
Em suma, trata-se da supervalorização do corpo magro, modelado, esculpido e atraente. A busca pelo corpo ideal explicaria os incontáveis procedimentos para adquiri-lo, reformá-lo e/ou preservá-lo, como explicou Sérgio Alves Teixeira (2001):

"cirurgias, implantes, ornamentações, cosméticos, vestimentas, exercícios, regimes alimentares, elixires, magias, rezas, compõem uma amostra bastante significativa de formas básicas de tais intervenções. Note-se que cada uma delas comporta múltiplas variedades, técnicas e nuances" (idem, p. 195).

É neste sentido que observamos uma tentativa de transformar diversos produtos e/ou objetos em mercadorias de primeira necessidade, e mais do que nunca, os cosméticos têm sido transformados em produtos indispensáveis em nosso cotidiano, devendo ser consumidos diariamente e até mesmo mais de uma vez por dia.

Nessa lógica do consumo, os cosméticos tornam-se produtos de uso obrigatório por toda a vida e certamente o segmento feminino aparece como o terreno mais fértil deste universo construído pela indústria da beleza. Há que se destacar também, como visto, que o crescimento da participação da mulher no mercado de trabalho no Brasil e no mundo tem proporcionado um aumento da renda familiar e reorganizado o orçamento doméstico e, desse modo, cada vez mais as mulheres decidem como gastar e onde alocar sua renda de trabalho. Outro fator de grande contribuição para o aumento do consumo de produtos de beleza diz respeito ao crescimento da renda populacional de um modo em 
geral e, especialmente, das classes C, D e E que no Brasil passam atualmente por uma crescente ascensão econômica. Ademais, há uma enorme diversidade de produtos e serviços voltados para atender todos os gostos e preferências de consumidores em potenciais, sejam eles crianças, jovens, idosos, mulheres, homens, heterossexuais, homossexuais ou metrossexuais, brancos, negros, ricos, pobres e até mesmo os animais domésticos contam hoje com inúmeros produtos de cuidado e limpeza. Outro aspecto dessas tendências recentes tem a ver com a difusão dos meios organizadores e indutores consumo a partir de uma infinidade de lugares e estabelecimentos que disponibilizam os serviços e produtos dessa indústria, sejam eles shopping centers, hipermercados, mercados, drogarias e farmácias, lojas especializadas, clínicas de estéticas ou cirurgia plástica, academias de ginástica, spas, etc.

Outro aspecto relevante diz respeito ao design, a apresentação da embalagem e o acondicionamento de um produto, consolidando-se desse modo como fatores diferenciais e decisivos deste competitivo mercado. "O packing pode melhorar, diz-se, em $25 \%$ a distribuição de um produto, muitas vezes basta uma nova embalagem para recuperar um produto desaquecido" (LIPOVETSKY, G., 1989, p. 191 e 192). As indústrias de cosméticos também têm destinado recursos crescentes na inovação e no desenvolvimento de embalagens, procurando agregar valor ao produto final e destacar uma aparência sedutora, de qualidade, estilo e sofisticação dos materiais utilizados em seus produtos.

Sob esse aspecto, as embalagens deixaram de ser apenas objetos standards (padrões), conferindo status e requisitos mais sofisticados, com rótulos mais personalizados e características diferenciadas (por exemplo, 
frascos com detalhes particularizados, cores, materiais e formas inovadoras), incluindo nesse caso o ecodesign.

\subsection{Valorização da Biodiversidade e Sustentabilidade Ambiental na Indústria de Cosméticos}

Nos últimos anos, o mercado de produtos derivados da biodiversidade encontra-se em fase de expansão seguindo a tendência mundial de alguns setores industriais na substituição de produtos sintéticos por naturais, e conferindo um papel cada vez mais relevante da pesquisa e desenvolvimento (P\&D) de novos ativos no aumento da competitividade tecnológica do setor de cosméticos e produtos de beleza.

A crescente oferta de matérias-primas originárias da biodiversidade vegetal tem tornado os produtos com ativos naturais cada vez mais acessíveis em diversas partes do mundo. A valorização desses tipos de produtos tem demonstrado uma mudança de hábito no consumo da população, influenciando diretamente os diferentes setores envolvidos no desenvolvimento de bioprodutos e envolvendo especialmente mudanças relacionadas às bases tecnológicas dos sistemas de produção. Pensar quais são os principais fatores que levam o crescimento do consumo desses produtos, bem como os novos comportamentos de um mercado consumidor cada vez mais rigoroso e ávido por produtos mais eficazes, inovadores e elaborados segundo as normas de sustentabilidade ambiental e social, exige um esforço de compreensão quanto aos processos que marcam essas mudanças.

O consumo de produtos desenvolvidos com bases naturais vai ao encontro com alguns dos novos valores da nossa sociedade contemporânea e 
que estão relacionados à valorização ambiental, à qualidade de vida em geral, à beleza, ao bem-estar e ao prazer, onde a saúde, a estética, a juventude e a aparência saudável podem também ser obtidas a partir do uso de ingredientes e formulações da "natureza". Nesse contexto, os produtos cosméticos baseados em ingredientes naturais apresentam embutido um valor intangível acerca do seu uso, representando valores associados a um estilo de vida, a uma atitude de engajamento cívico e ao que é considerado "ambientalmente correto" e socialmente responsável.

A demanda por produtos naturais e/ou orgânicos registram mudanças em curso relacionadas a diversos aspectos e especialmente aqueles envolvidos com as questões ambientais. A crescente preocupação com o consumo excessivo dos recursos naturais e os problemas ambientais associados à perda da biodiversidade, poluição atmosférica, aquecimento global, descarte de resíduos e desmatamento, ganharam força nas últimas décadas e assumiram papel de destaque no debate ambiental contemporâneo. Como lembra Milton Santos (2004a): “a chamada crise ambiental se produz neste período histórico, onde o poder das forças desencadeadas num lugar ultrapassa a capacidade local de controla-las, nas condições atuais de mundialidade e de suas repercussões nacionais" (idem, p. 253).

Esse quadro impulsionou a internalização da sustentabilidade ambiental em diferentes níveis e colocou em pauta também o modelo de aproveitamento dos recursos, assim como, o desenvolvimento e a comercialização de diversos produtos. Como apontou Enrique Leff (2000), a degradação e os impactos no meio ambiente marcam um sintoma da modernidade e problematizam as bases de produção, em outras palavras: 
"o princípio da sustentabilidade emerge assim no contexto da globalização econômica, como uma nova visão do processo civilizatório da Humanidade. A crise ambiental veio questionar as bases conceituais que impulsionaram e legitimaram o crescimento econômico, negando a Natureza. A sustentabilidade ecológica surge, assim, como um critério normativo na reconstrução da ordem econômica, como condição de sobrevivência humana e para se alcançar um desenvolvimento durável, problematizando as próprias bases da produção" (idem, p. 261).

Há pouco mais de quatro décadas, os inúmeros impactos ambientais decorrentes dos modelos de produção e desenvolvimento vigentes desencadearam vários debates internacionais sobre o meio ambiente e promoveram diferentes mobilizações políticas, econômicas e sociais em torno dessa temática. Na década de 1970, a questão ambiental esteve fortemente marcada por divergências entre os países mais industrializados e os periféricos quanto aos impactos e às responsabilidades dos problemas ambientais, embora alguns desses conflitos continuem presentes nos dias de hoje. Além disso, a conservação ambiental e o desenvolvimento econômico, discursos até então muito distantes, passaram a integrar conjuntamente a mesma agenda e em 1971 foram esboçados pela primeira vez as bases do conceito de desenvolvimento sustentável no Encontro Preparatório de Founex, na Suíça (SACHS, I., 2009).

Foi nesse cenário que a Conferência de Estocolmo (1972), primeira grande referência da "ordem ambiental internacional" (RIBEIRO, W. C., 2001), 
marcou um novo ciclo de debates sobre os problemas ambientais, que naquela época estavam centrados notadamente nas discussões sobre poluição atmosférica, dos estoques de recursos não renováveis (sobretudo no tocante às reservas de petróleo), da pressão do crescimento demográfico sobre os recursos naturais e do desenvolvimento industrial. Durante a preparação da Conferência, foram manifestadas duas posições opostas, a do crescimento zero e a desenvolvimentista, conforme avaliado por Ignacy Sachs (2009):

"Os primeiros consideravam que as preocupações com o meio ambiente eram descabidas, pois atrasaria, e inibiriam os esforços dos países em desenvolvimento rumo à industrialização para alcançar os países desenvolvidos (...). A prioridade deveria ser dada à aceleração do crescimento (...). Do lado oposto, os pessimistas anunciavam o apocalipse para o dia seguinte, caso o crescimento demográfico e econômico ou pelo menos o crescimento do consumo - não fossem imediatamente estagnados (...). Alguns desses pessimistas eram malthusianos. Para eles, a perturbação do meio ambiente era consequência da explosão populacional, como se o número de não consumidores - a maioria pobre - importasse mais do que o consumo excessivo da minoria abastada" (idem, p. 50, 51 e 52).

No contexto da Conferência de Estocolmo, foi evidenciada também a reinvindicação dos países em desenvolvimento sobre o modo de produção adotado nos países mais industrializados como o principal causador da crise 
ambiental e não a pressão humana do crescimento demográfico em seus países, como as nações ricas apontavam. Nessa direção, deu-se início um processo gradual de discussão sobre as alternativas possíveis de aproveitamento dos recursos naturais e do crescimento econômico, denominado naquele momento de ecodesenvolvimento, termo cunhado por Sachs ainda em 1974 (RIBEIRO, W. C., 2001). O ecodesenvolvimento deveria integrar os aspectos sociais, culturais e ambientais. De acordo com Héctor Leis (1999), no âmbito das relações internacionais, o ecodesenvolvimento criticava o caráter das relações norte-sul e, no contexto econômico-cultural criticava o progresso originado pela modernização industrial.

A formulação do conceito de desenvolvimento sustentável teve continuidade após Estocolmo e consolidou-se a partir dos trabalhos da Comissão Mundial para o Meio Ambiente e Desenvolvimento (CMMAD) com o documento intitulado Nosso Futuro Comum, o Relatório Brundtland, publicado em 1987, e que concebeu o conceito como "o desenvolvimento que satisfaz as necessidades presentes, sem comprometer a capacidade das gerações futuras de suprir suas próprias necessidades" (CMMAD, 1988). Esse conceito tornouse referência, passando a servir a interesses diversos, conforme analisado por Ribeiro (2001):

"De nova ética do comportamento humano, passando pela proposição de uma revolução ambiental até ser considerado um mecanismo de ajuste da sociedade capitalista (capitalismo soft), o desenvolvimento sustentável tornou-se um discurso poderoso promovido por organizações internacionais, 
empresários e políticos, repercutindo na sociedade civil internacional" (idem, p. 113)

A partir disso, a temática ambiental foi efetivamente introduzida na agenda global e uma série de encontros e relatórios continuou debatendo essas questões, culminando vinte anos depois na Conferência das Nações Unidas para o Meio Ambiente e o Desenvolvimento (CNUMAD) em 1992. A CNUMAD realizada no Rio de Janeiro, conhecida como Rio-92, teve como principais pontos de discussão a associação do binômio conservação ambiental e desenvolvimento, relacionados segundo 0 conceito do desenvolvimento sustentável. Nessa ocasião, foram estabelecidos dois acordos internacionais que tratavam sobre o acesso/manutenção da biodiversidade e das mudanças climáticas globais, como também duas declarações: das Florestas e do Rio (princípios pela preservação da vida na Terra). Além desses acordos, foi elaborada a Agenda 21, que destacou um plano de ação para a virada do século, enfatizando a problemática ambiental mundial (RIBEIRO, W. C., 2001) e também apontou como uma das principais causas da degradação e da exclusão social, os atuais padrões de produção e consumo (UNITED NATIONS, 1992).

Os documentos ali produzidos ganharam visibilidade diante a opinião pública e fomentaram o tema em outros fóruns multilaterais, como examinado novamente por Ribeiro (2001). Posteriormente a Rio-92, diversas reuniões e conferências entre as partes signatárias (COP) mantiveram as discussões e deliberações sobre os assuntos relacionados às implementações dos Protocolos e, ainda, foram seguidos de mais uma Conferência das Nações Unidas (Rio+10) em Johanesburgo, África do Sul, em 2002. 
Passados mais vinte anos da Conferência no Rio de Janeiro, a Rio+20, realizada recentemente, também representou mais um momento no arranjo das relações internacionais sobre a temática ambiental, enfatizando novamente o desenvolvimento sustentável como o caminho a ser seguido e os temas em destaque estavam relacionados à segurança alimentar, água, oceanos, energia, erradicação da pobreza, emprego, saúde, mudanças climáticas, consumo e produção sustentáveis. Como desdobramento desse encontro, os países elaboraram uma declaração final contendo as metas e ações a serem implementadas, embora muitos dos princípios ali estabelecidos já constassem de cúpulas anteriores e que ainda não haviam apresentado resultados suficientes (ONU, 2012).

Diferentes atores e processos emergiram ao longo dos debates sobre 0 meio ambiente. Dentre os movimentos mais significativos, Eduardo Viola (1996) destacou: as organizações não-governamentais e grupos comunitários que lutam pela proteção ambiental; agências estatais em diferentes níveis de governabilidade; grupos e instituições científicas; setores envolvidos na implementação de gestão de processos produtivos baseado na eficiência de materiais, otimização de energia, redução da poluição, ecodesign e qualidade; surgimento de um mercado consumidor "verde" que demanda produtos sustentáveis (alimentos orgânicos, papel reciclado, produtos desenvolvidos a partir de tecnologias limpas, etc); redes multisetoriais responsáveis pelo monitoramento de processos de produção e qualificação dos produtos, por exemplo, os selos verdes e as normas de padronização ISO 14000; e, finalmente, os tratados internacionais para a regulação do cenário ambiental global (VIOLA, E., 1996). 
Essa breve contextualização da agenda ambiental internacional demonstra como a temática foi sendo abordada desde a Conferência de Estocolmo. Diante desse quadro de referências, discursos que merecem atenção referem-se aos impactos causados pelos elevados padrões de consumo e o papel das empresas na atual dinâmica relativa ao meio ambiente, principalmente nas últimas décadas. A emergência destas questões geraram significativas mudanças em diversos setores, seja por pressão dos movimentos ambientalistas mediante denúncias ou protestos de variados tipos, seja por pressão política ou dos próprios consumidores e do empresariado que também se apropriaram do discurso ambiental. No interior dessa discussão, o conceito de sustentabilidade, apesar de suas ambiguidades, emerge novamente como ponto central na busca de uma alternativa para o uso dos recursos naturais, a conservação ambiental, o crescimento econômico, o consumo consciente e a responsabilidade social.

Observamos uma crescente mudança no comportamento da sociedade em geral no que diz respeito ao consumo de diversos produtos, sobretudo quando eles ostentam o rótulo de "orgânicos", "bio", "verdes", "sustentáveis" ou "ecológicos", ainda que, por vezes, existam divergências entre uma consciência ambiental e sua prática de fato. Diferentes setores têm adotado a linha "bio", com destaque para os alimentos, os cosméticos e produtos de higiene pessoal, medicamentos, produtos de limpeza, os setores de vestuário, embalagem, móveis, dentre outros. A influência da variável ambiental no desenvolvimento de produtos, como também nos processos produtivos, indica uma tendência global de expansão dos mercados verdes, embora ela seja mais visível ainda em um grupo de países, por exemplo, EUA, Japão, França, Alemanha e Itália. No Brasil, esse mercado ainda encontra-se em fase incipiente se comparado 
aos demais países citados, de todo modo, estudos sobre o consumo de produtos sustentáveis projetam significativo crescimento para as próximas décadas.

Alguns fatores que influenciam diretamente o crescimento desse segmento estão relacionados a maior disponibilidade de ingredientes e ativos naturais devido às atividades de Pesquisa, Desenvolvimento e Inovação $(P, D \& I)$ do setor industrial, impactando diretamente os mercados especializados nestes tipos de produtos (desde os setores responsáveis pelo abastecimento de matérias-primas até os de controle de qualidade e produção industrial). Também às transformações nos hábitos de consumo com 0 interesse em produtos saudáveis, mais seguros e livres de substâncias sintéticas em sua composição; a crescente preocupação com o meio ambiente; às mudanças de estratégia de mercado das empresas, isto é, a intensificação da produção de bens finais derivados de ativos naturais e a certificação ambiental.

Nesse contexto, as questões ambientais começaram a ser percebidas como desdobramentos da qualidade de vida, colocando o consumo como parte integrante da responsabilidade ambiental e social. É neste sentido que emerge um novo tipo de consumidor, ou seja, aquele que leva em conta a variável ambiental em praticamente todas as etapas do ciclo de vida de um produto, como também aquele que valoriza os produtos certificados, elaborados de forma sustentável com embalagens recicladas ou biodegradáveis, com matérias-primas renováveis e/ou insumos reutilizados, que economizam água e energia, entre outros. Alguns autores definem esse consumidor como aquele que busca consumir produtos verdes ou ecológicos que causem pouco impacto ao meio ambiente (OTTMAN, J. A., 1994); ou como o indivíduo que leva em 
consideração os produtos ambientalmente corretos e não somente a qualidade e o preço final (LAYRARGUES, P. P., 2000); ou que escolhe o produto mediante a variável ambiental, além de qualidade/preço (PORTILHO, M. F., 2005); e, ainda, o consumidor que manifesta uma preocupação com o meio ambiente, adotando um comportamento coerente com esses valores (DIAS, R., 2007). Nos EUA, os consumidores verdes reúnem mais de 40 milhões de norte-americanos e são denominados como "lohas" (lifestyles of health and sustainability), formados majoritariamente pelo público feminino (cerca de $60 \%$ do total), possuem alta escolaridade e aceitam desembolsar até $20 \%$ a mais por produtos sustentáveis (The Marketing Insider, 2010).

Por outro lado, cabe destacar também que algumas incongruências surgem rapidamente quando falamos de bioprodutos sustentáveis, ecológicos ou produtos "verdes", tendo em vista que qualquer tipo de produção industrial faz uso de energia e de recursos naturais em suas diferentes etapas (coleta de materiais, estocagem, produção e distribuição), gerando resíduos e emissões em alguma medida. Ademais, as empresas e fornecedores de insumos e matérias-primas ao longo de toda a cadeia produtiva devem também estar atentos às exigências e normas ambientais.

O tema que envolve o impacto ambiental do consumo foi definido, segundo Portilho (2005), nos limites da noção de "consumo verde", sendo posteriormente identificado no "consumo sustentável". Conforme analisado pela autora, a concepção de um consumo verde esteve basicamente associada a três aspectos principais: com o ingresso do movimento ambientalista no debate público internacional partir da década de 1970; a "ambientalização" do setor empresarial nos anos 1980; e a crescente preocupação ambiental dos estilos de vida e do consumo desde o início da década de 1990. 
No período entre os anos 1970 e 1990, um novo modelo de gestão, produção industrial e tecnológica, assim como a adoção de mecanismos de prevenção e controle ambiental, marcam definitivamente a introdução de um "ambientalismo empresarial". Na década de 1970, a dimensão ambiental ainda estava longe de ser um consenso para o setor e era considerada como um freio ao crescimento econômico (RIBEIRO, W. C., 2001; LEFF, E., 2000). Suas ações nesse sentido eram tomadas praticamente apenas como imposição das normas e legislações ambientais determinadas pelos governos e o setor também era repetidamente culpado como um dos grandes responsáveis pelos impactos ambientais e pela poluição, denunciados notadamente pelos movimentos ambientalistas. Já em meados de 1980, o empresariado passou a incorporar uma série de medidas necessárias diante da sustentabilidade ambiental e, deste modo, o setor ganhou expressivo destaque na década seguinte por sua participação ativa e responsabilidade sobre essas questões, cuja adesão passou a ser voluntária e fruto do aumento da consciência ambiental (FORTES, M., 1992; SOUZA, M. T., 1993, DONAIRE, D., 1995; LAYRARGUES, P. P., 2000). Esse deslocamento de estratégia foi identificado por Layrargues (2000), como uma "apropriação ideológica", onde o setor se apropriou do discurso ambiental para o enfrentamento do projeto de uma sociedade ambientalmente sustentável, propondo o caminho entre a tecnologia limpa e o consumo verde, porém de acordo com a sua lógica interna (PORTILHO, M. F., 2003).

A mudança do modelo de desenvolvimento convencional e poluidor para um novo tipo de produção industrial baseado no modus operandi dos princípios ecológicos marca um importante avanço na relação entre empresas, fornecedores de matérias-primas, consumidores e meio ambiente, da mesma 
forma, que modifica a organização produtiva e introduz novas tecnologias em diferentes escalas. Em um cenário altamente competitivo e globalizado, o setor empresarial é cada vez mais pressionado a aderir a uma série de normas, padronizações e certificações de seus produtos e processos, sejam eles vinculados ao Sistema de Gestão Ambiental (SGA), à adesão da ISO 14000 (e normas derivadas) ou dos rótulos ambientais, por exemplo, representando apenas algumas das etapas do longo caminho para a sustentabilidade.

Os últimos anos indicam um intenso crescimento dos organismos e empresas de certificação ambiental, e no caso dos cosméticos, identificamos principalmente a rotulagem dos produtos com o selo verde ou eco-label indicando a existência de tipos e frações da biodiversidade vegetal, atestando o uso e a origem de ingredientes orgânicos. Uma característica importante dessas tendências é a valorização da procedência geográfica das matériasprimas e dos pequenos produtores familiares envolvidos com esses sistemas produtivos. Essa perspectiva de valorização das especificidades territoriais e regionais, o "efeito terroir", é intensamente reforçada nos produtos desenvolvidos a partir da biodiversidade da Amazônia ou também com as ervas e plantas da região de Provence na França ou ainda das plantas medicinais originárias da Índia ou China, por exemplo.

Embora as medidas de certificação atuem como relevantes instrumentos de comunicação e conformidade dos critérios ambientais sobre a origem das matérias-primas ou o modo de fabricação de um produto, ao mesmo tempo, elas podem ser incompreensíveis para o consumidor, como também questionáveis ao classificar um produto como "natural" ou "verde", tendo em vista que apenas uma pequena parcela das substâncias ali contidas pode ser 
considerada de fato natural ${ }^{1}$. Desse modo, os mecanismos de certificação operam como importantes reguladores nas atuais condições de competitividade mundial do setor, especialmente das grandes empresas que detêm mais recursos, competência científica e capacidade em inovação tecnológica. Além do mais, destacamos as ações e estratégias de marketing ambiental das empresas, que fazem uso de diversos artifícios de valorização dos benefícios ambientais como vantagem competitiva e, portanto, o mercado verde seria mais uma forma de atender as necessidades de reprodução ampliada do capital.

Incorporar a variável ambiental em um ambiente de competição internacional significa um reordenamento do modo de produção e a introdução de tecnologias e inovação ao longo das cadeias produtivas. Sob esse aspecto, a ordem ambiental não seria mais a precursora das transformações no âmbito empresarial. Essas transformações teriam no desenvolvimento tecnológico, além do fenômeno do consumo, o seu maior agente e introdutor das mudanças necessárias para o alcance da sustentabilidade e da maior eficiência produtiva, ora por meio de tecnologias limpas ou na redução do uso de recursos naturais e energia ou na geração de resíduos. Motivados pela renovação dos mercados e na diversificação de produtos e suas aplicações, no caso dos cosméticos e de outros ramos de produção, verificamos uma intensificação dos investimentos em biotecnologia, por exemplo (ALBAGLI, S., 1998a). A esse respeito Layrargues (2000), aponta que a incorporação da variável ambiental no setor industrial partiu, principalmente, de uma sensibilização econômica e

\footnotetext{
${ }^{1}$ As questões sobre a certificação de produtos naturais são tratadas no Capítulo 4. Cabe ressaltar, entretanto, que a ausência de padronizações entre os próprios órgãos reguladores/certificadores internacionais e nacionais dificultam a diferenciação dos produtos para o mercado consumidor.
} 
não ecológica. Legitimar a mudança da cultura empresarial somente à questão ambiental mascara os verdadeiros processos de um mercado absolutamente mundializado. O autor afirma que isso se deve, em grande parte, ao:

"rearranjo no eixo político-econômico internacional, em que se deslocou a vantagem competitiva da matriz tecnológica de mão-deobra intensiva para capital intensiva, originando, assim, as novas tecnologias, que, num movimento de interesses convergentes entre o acréscimo de produtividade industrial e a demanda ecológica, produziram a tecnologia limpa. A transição industrial orientada pela modernização tecnológica visa, em primeiro lugar, a reduzir custos para aumentar a competitividade. Se esse feito for benéfico ao meio ambiente, tanto melhor, pois controlar a poluição também representa uma economia de recursos, além do que a aquisição de uma imagem empresarial positiva diante da opinião pública também se constitui num valioso recurso altamente explorável nas campanhas de marketing" (idem, p. 84).

Outra mudança estaria ocorrendo com o deslocamento das questões ambientais para a esfera do indivíduo comum, isto é, os comportamentos e práticas individuais passam a ser entendidos como corresponsáveis da qualidade ambiental e necessários para uma sociedade sustentável (PORTILHO, M. F. F., 2005). O processo de transferência de responsabilidade para os consumidores, ao mesmo tempo em que reflete novas demandas e preocupações com o meio ambiente, também acarreta a incorporação da 
variável ambiental para o consumidor final. A partir dessas observações, Portilho (2005) considera que:

"A estratégia de consumo verde pode ser analisada, ainda, como uma espécie de transferência da atividade regulatória em dois aspectos: do Estado para o mercado, através de mecanismos de auto-regulação; e do Estado e do mercado para o cidadão, através de suas escolhas de consumo. Assim, ambos - governos e empresas - encorajariam a responsabilidade individual, implícita ou explicitamente, através de referências ao poder do consumidor, ao "bom cidadão" ou à valorização da contribuição pessoal de cada um, transferindo a responsabilidade para um único lado da equação: o indivíduo" (idem, p. 3).

Trata-se, portanto, de deslocar a responsabilidade quanto ao controle e à qualidade ambiental diretamente para o consumidor final, sendo suas escolhas identificadas como os "termômetros" que executarão pressão sobre os sistemas de produção. Esse seria "novo perfil do indivíduo, moldado para o consumo enquanto estratégia superior de acumulação do capital", quanto a isso, Antas Jr (2007) afirma:

"O consumo torna-se, assim, num complexo processo pelo qual as corporações têm regulado os comportamentos dos indivíduos. Se de um lado o Estado produz regulação pela via do indivíduo-cidadão, que constitui a relação formal de poder 
soberano, de outro as grandes empresas processam regulação pela via do indivíduo-consumidor. Hoje, essa regulação privada, que é crescentemente corporativa no Brasil e no mundo, tem interferido nas relações sociais de modo a condicioná-las para as estratégias de consumo" (idem, p. 101).

Entre outros aspectos acerca da valorização do uso da biodiversidade, e no caso específico dos cosméticos, observamos uma elitização e estilização dos bioprodutos desenvolvidos sob essa lógica e que são, normalmente, destinados a um determinado perfil de consumidores. Nessa perspectiva, as grandes empresas (por exemplo, Natura, L'Oréal, O Boticário, L'Occitane, entre outras) estão se valendo dessas operações, já que além dos aspectos convencionais indispensáveis à competitividade, como a diversificação de mercados e produtos, elas possuem mais capacidade de arcar com os altos custos de marketing, investimentos em pesquisas de novos insumos e nos processos de rastreabilidade das matérias-primas para sua certificação, controle do fornecimento de insumos, a obtenção dos registros pelos órgãos responsáveis e até mesmo patentes. Desse modo, os custos finais dos produtos sustentáveis tendem a ser mais onerosos, incidindo diretamente no consumidor que deverá pagar por um produto diferenciado e com alto valor agregado.

É preciso atentar também que as empresas de cosméticos se caracterizam por ser um dos setores industriais que os consumidores mais associam a questão da "imagem" (ABIHPEC, 2012). Essencialmente, elas estão vinculadas aos cuidados com a aparência e, desse modo, as empresas que valorizam a sustentabilidade carregam consigo o fortalecimento de uma 
imagem corporativa positiva, de empresas ambientalmente e socialmente responsáveis, sendo cada vez mais determinantes na decisão de compra dos consumidores.

Nesse sentido, o marketing verde beneficia, duplamente, às corporações que dele se apropriam: (i) ele agrega valor à imagem dessas corporações - sua "boa reputação"-, as transformando como agentes detentoras de responsabilidade socioambiental e, assim, paralelamente, as protegem dos riscos gerados por uma imagem que seja vinculada estritamente à obtenção de lucros; (ii) ao mesmo tempo, os custos dessa boa imagem são repassados ao consumidor final como um princípio cidadão, ao ser divulgado que o exercício da cidadania passa também por um "consumo consciente". Exemplos dessa perspectiva podem ser observados em mensagens de empresas do setor, como O Boticário ("A Beleza das atitudes"), Natura ("Bem estar bem") e Unilever ("Cada Gesto Conta"). 


\section{CAPÍTULO 2 - A INDÚSTRIA DE HIGIENE PESSOAL, PERFUMARIA E COSMÉTICOS: panorama internacional e nacional do setor}

Segundo a literatura especializada e a autodefinição do setor, a indústria de higiene pessoal, perfumaria e cosméticos é um segmento da indústria química, vinculada à manipulação de fórmulas para o desenvolvimento de produtos de aplicação no corpo humano visando a limpeza, o embelezamento ou para alterar a aparência. O setor apresenta diversas interações com outros segmentos, por exemplo, a indústria farmacêutica e até mesmo a alimentícia. Desse modo, há certa dificuldade de delimitar as suas fronteiras externas e internas, já que em geral, muitas empresas que produzem cosméticos também fabricam produtos de perfumaria e de higiene pessoal e parte delas desenvolve atualmente fortes interações com empresas de fora do seu segmento tradicional.

A classificação nacional para produtos cosméticos, higiene pessoal e perfumes tem como base a definição elaborada pela $\mathrm{ANVISA}^{2}$, conforme indicado no Capítulo 1 deste trabalho. Registre-se que a definição estabelecida pelo órgão brasileiro encontra-se alinhada com as resoluções adotadas internacionalmente, atendendo desse modo as principais diretrizes do setor e, sobretudo, no que diz respeito à exportação dos produtos desenvolvidos no país.

Em seus traços gerais, essa indústria encontra-se organizada em pelo menos três subsetores principais: Higiene Pessoal (sabonetes, produtos para

\footnotetext{
2 Resolução no 211, de 14 de julho de 2005, que define cosmético como: "preparações constituídas por substâncias naturais ou sintéticas, de uso externo nas diversas partes do corpo humano, pele, sistema capilar, unhas, lábios, órgãos genitais externos, dentes e membranas mucosas da cavidade oral, com o objetivo exclusivo e principal de limpá-los, perfumá-los, alterar sua aparência e ou corrigir odores corporais e ou protegê-los ou mantê-los em bom estado" (Anexo 2).
} 
higiene capilar, óleos e espumas de banho, desodorantes, produtos para higiene oral e para barbear, talcos, absorventes higiênicos, fraldas descartáveis, entre outros), Cosméticos (maquiagem, cremes e loções para pele, protetores solares, produtos de coloração e tratamento de cabelos, fixadores e modeladores, depilatórios, produtos para unhas, entre outros) e Perfumaria (perfumes e essências, águas de colônias, produtos pós-barba, entre outros) (CAPANEMA, L. et al., 2007).

Tendo em vista essas definições usualmente adotadas pelo setor, utilizaremos em nosso trabalho os termos "cosméticos" e "indústria de cosméticos" para designar respectivamente os produtos e os segmentos relacionados ao desenvolvimento de produtos de higiene pessoal, perfumaria e cosméticos, ou seja, em diversos momentos englobaremos em "cosméticos" o conjunto dos produtos dos três subsegmentos.

A diversidade do setor industrial de cosméticos está vinculada à multiplicidade de estratégias de produções e mercados, sendo notada a existência daquelas indústrias com atuação global em diversas atividades correlatas decorrentes da proximidade entre elas. As grandes indústrias líderes do mercado envolvem, em sua maioria, grupos transnacionais que apresentam as atividades produtivas consolidadas e estruturadas, bem como, bases técnicas mais rigorosas. Desse modo, especialistas do setor trataram de agrupar os principais atores da indústria de cosméticos segundo suas estratégias de produção e mercado (GARCIA, R.; FURTADO, J., 2002; GARCIA, R., 2005), destacando quatro grupos: indústrias com atuação diversificada; indústrias com atuação concentrada; indústrias de venda direta; e indústrias com lojas próprias e/ou franquias. 
i. Indústria de atuação diversificada: formado por grandes conglomerados transnacionais que atuam no setor de higiene pessoal, cosméticos e perfumes e em setores afins (farmacêutico e alimentício). Como atua em segmentos diversificados apresenta facilidade de mesclar atividades de produção, pesquisa e desenvolvimento (P\&D), comercialização e normalmente os produtos são fabricados em larga escala. Os canais de distribuição são basicamente os de varejo tradicionais: hipermercados, supermercados, lojas de atacado, farmácias e drogarias. Exemplos de indústrias diversificadas: Procter \& Gamble (P\&G; norte-americana), Unilever (anglo-holandesa), ColgatePalmolive (norte-americana) e a Johson \& Johnson (J\&J; norte-americana).

ii. Indústria de atuação concentrada: atua em sua maioria apenas na fabricação de cosméticos e perfumes, dedicando-se ao desenvolvimento de produtos mais sofisticados, ativos e embalagens diferenciadas, como também investe pesadamente em atividades inovadoras e tecnológicas. A distribuição dos produtos é realizada em lojas especializadas em produtos de beleza, salões, centros de estética e spas. Exemplos de indústrias concentradas: L'Oréal (francesa), LVMH (francesa), Estée Lauder (norte-americana), Revlon (norte-americana), Coty (norte-americana) e Shiseido (japonesa).

iii. Indústria de venda direta (door-to-door): comercializa e distribui os produtos por meio de revendedores autônomos. Os produtos comercializados "porta a porta" concentram-se normalmente em produtos mais populares e tradicionais e compreendem uma série de outros itens que não sejam cosméticos, por exemplo, utensílios domésticos, joias, roupas íntimas. 
Exemplos de venda direta: Natura (brasileira), Avon (norte-americana), Mary Kay (norte-americana), Nu Ski (norte-americana) e Oriflame (sueca).

iv. Indústria com lojas próprias ou franquias: atua com estratégias concentradas em produtos do setor e que são distribuídos pelos sistemas de franquias ou lojas próprias. Registre-se que as principais e maiores indústrias desse grupo são importantes representantes do segmento de cosméticos naturais ou derivados em ativos da biodiversidade. Exemplos de empresas: The Body Shop (marca inglesa adquirida pela L'Oréal), L'Occitane (francesa), Yves Rocher (francesa) e O Boticário (brasileira).

Nesse contexto, o setor de cosméticos, higiene pessoal e perfumaria é bastante diversificado, abrangendo indústrias de diferentes portes e com múltiplas formas de atuação, desde micro, pequenas e médias indústrias até as empresas líderes que são, em sua maioria, transnacionais e que detêm todas ou algumas etapas estratégicas da cadeia produtiva. Assim, existem as indústrias que dedicam suas atividades exclusivamente às etapas de processamento de matérias-primas para posterior fornecimento dos insumos às indústrias responsáveis pelo produto final, bem como, aquelas que desenvolvem todas as etapas de produção até a comercialização final nos mercados consumidores, e ainda os distribuidores de insumos ao longo de toda cadeia produtiva.

No que se refere à comercialização de produtos acabados, existem diferentes canais de varejo tradicionais, que vão desde lojas próprias ou de departamentos, franquias, hipermercados, supermercados, shoppings centers, 
salões de beleza; lojas especializadas, spas, academias de ginásticas e, além disso, o setor conta com vendas diretas porta a porta ou pela internet.

Em nosso trabalho optamos por abordar os agentes e as etapas produtivas deste setor industrial segundo o conceito de cadeia produtiva, proposto por Albagli e Britto (2002), como sendo "o encadeamento de atividades econômicas pelas quais passam e vão sendo transformados e transferidos os diversos insumos, incluindo desde as matérias-primas, máquinas e equipamentos, produtos intermediários até os finais, sua distribuição e comercialização" (idem, p. 8). De acordo com os autores, a cadeia produtiva implica em crescente divisão do trabalho e especialização em etapas distintas do processo produtivo, podendo englobar o âmbito local, regional, nacional ou mundial.

Compartilhando dessa perspectiva, Dantas, Kertsnetzky e Prochnik (2002) afirmam que: "as cadeias produtivas resultam da crescente divisão do trabalho e maior inderdependência entre os agentes econômicos. Por um lado, as cadeias são criadas pelo processo de desintegração vertical e especialização técnica e social. Por outro lado, as pressões competitivas por maior integração e coordenação entre as atividades, ao longo das cadeias, amplia a articulação entre os agentes" (idem, p. 36 e 37; apud Casttillo, R.; Frederico, S., 2010). Desse modo, a cadeia produtiva dos cosméticos é formada basicamente pelos seguintes agentes (MIGUEL, L. M., 2007; FERRO, A., 2010):

i. Produtores de matérias-primas: fornecimento de insumos vegetais brutos ou pré-beneficiados (óleos, extratos, corantes naturais, resinas, fibras e manteigas de origem animal e vegetal) e insumos químicos (derivados da indústria petroquímica); 
ii. Produtores secundários: fornecimento de equipamentos, máquinas, embalagens, rótulos ou insumos processados (princípios ativos ou químicos produzidos em pequenas, médias ou grandes quantidades ${ }^{3}$ ).

iii. Centros, institutos e empresas de pesquisa: agentes envolvidos em atividades de pesquisa e desenvolvimento (P\&D) de matérias-primas e/ou insumos industrializados e também de processos industriais.

iv. Indústrias de produtos finais e empresas terceirizadas: fabricantes de produtos acabados (detentores de marca ou fabricantes terceirizados);

v. Distribuidores: distribuição interna e/ou importação/exportação de insumos ou produtos acabados;

vi. Licenciadores e reguladores: órgãos responsáveis pela regulamentação técnica e normativa do setor; aprovação de registros, notificações, etc.

vii. Certificadores: empresas responsáveis pela certificação da origem/tipo de matérias-primas e dos processos de produção segundo determinadas normas técnicas/ambientais;

viii. Varejistas: comercialização de produtos acabados;

ix. Consumidor final.

A indústria de cosméticos é intensamente caracterizada pela constante necessidade de inovações de seus produtos e processos, sendo considerada atualmente, um dos setores industriais mais inovadores e dinâmicos. O crescimento do mercado para esses tipos de produtos de tecnologia avançada propicia também oportunidades para a inovação nos processos de exploração

\footnotetext{
3 Os insumos processados podem ser, por exemplo, conservantes, corantes, essências, aromas, polímeros condicionantes, emolientes, formadores de filme, polímeros fixadores de cabelo, agentes controladores de reologia, agentes clareadores de pele, ativos anti-idade, sistemas de liberação controlada de ativos, filtros UV, entre outros (FERRO, A., 2010, p. 75).
} 
no que tange ao uso alternativo dos produtos existentes e na melhoria do seu desempenho nas etapas de inventário, coleta, estocagem, extração de substâncias e compostos, experimentos laboratoriais químicos e farmacológicos e processamento industrial final. Um dos estudos do setor aponta que $35 \%$ do faturamento das empresas encontram-se atualmente apoiados nos lançamentos de novos produtos (CHAVES apud FERRO, A., 2006). A capacidade de inovação tecnológica e das atividades de $P \& D$, a incorporação de novos insumos e princípios ativos, a produção de novas embalagens, entre outros, são alguns dos atributos indispensáveis para a competição dessas indústrias e o desenvolvimento de produtos mais diferenciados.

\subsection{O Mercado Mundial e Brasileiro}

Há pelo menos duas décadas, os setores envolvidos com a indústria da beleza e especialmente dos segmentos de produtos cosméticos e perfumaria demonstram expressivo crescimento em âmbito global. O consumo mundial de produtos cosméticos quase dobrou entre o período de 2006 e 2011 (Gráfico 4) e as projeções do setor apontam que esse crescimento deverá se manter nos próximos anos (EUROMONITOR, 2012). 


\section{Gráfico 4 - Mercado de Consumo Mundial de Cosméticos entre 2006 e 2011 (US\$ bilhões)}

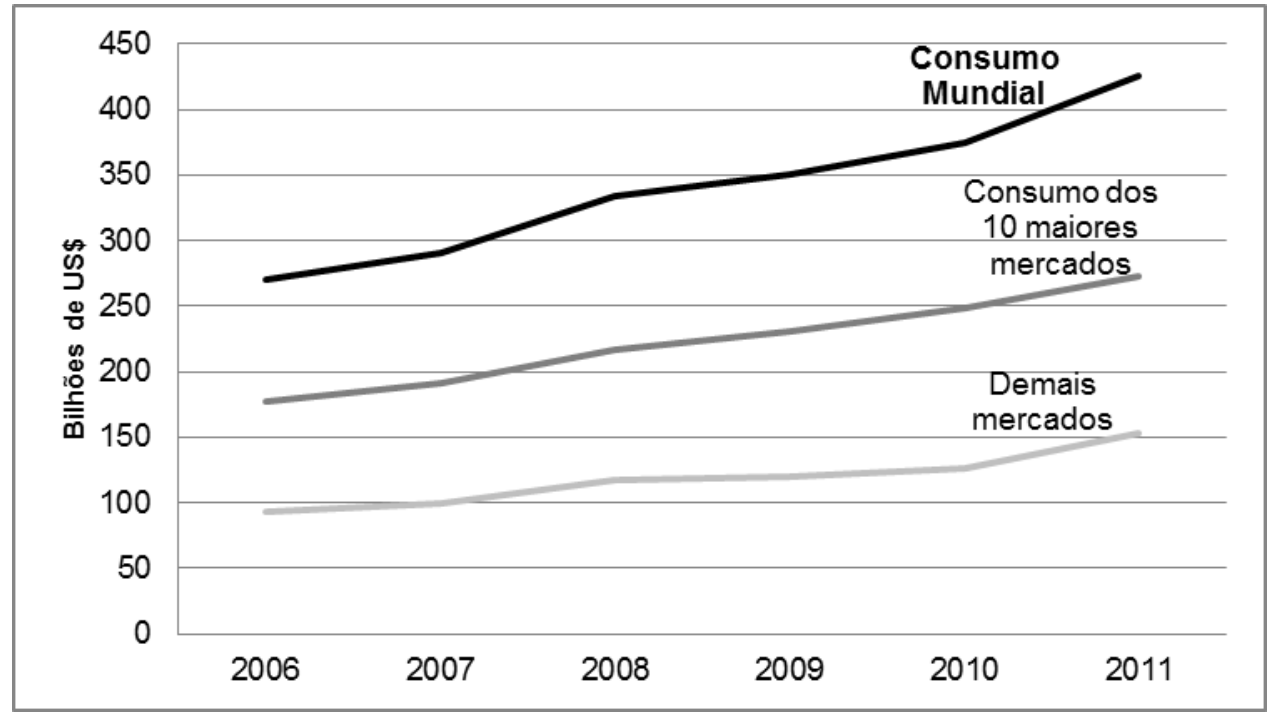

Fonte: Euromonitor, 2006-2011. Elaboração da Autora, 2012.

Em termos de importância para o mercado de consumo de cosméticos, a Europa lidera, com $37 \%$ do mercado mundial, consolidando os aspectos culturais e hábitos de consumo de sua população, no que se refere aos cuidados com a aparência. Em seguida, a Ásia também apresenta elevado peso no consumo mundial de cosméticos com $26 \%$, e analistas do setor apontam que um dos fatores responsáveis para essa demanda está associado ao alto consumo de produtos para a pele, sobretudo clareadores faciais (GARCIA, R., 2005) O Gráfico 5 mostra a evolução do market share no mundo, indicando que a Europa ainda permanece na liderança mesmo que tenha perdido parcelas do mercado de consumo para outros mercados regionais, sobretudo para a América Latina. 
Gráfico 5 - Evolução do market share do setor industrial de cosméticos por regiões entre 2003 e 2010

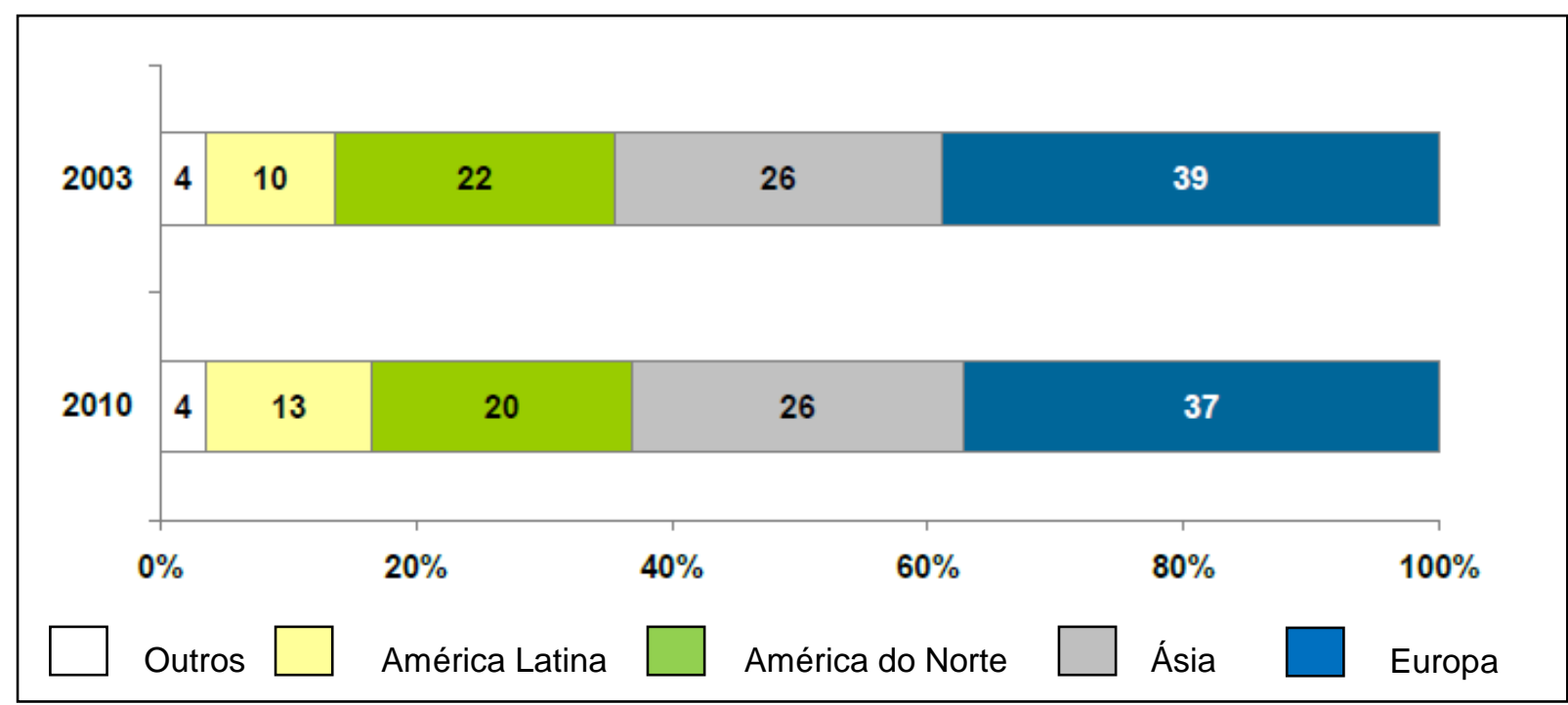

Fonte: Kline \& Company, 2011.

A Agência Analista de Mercado Euromonitor apresenta o panorama dos principais mercados mundiais da indústria de cosméticos, sendo apontado no levantamento de 2011 um crescimento de 9,8\% do consumo mundial desses produtos em relação ao ano anterior, totalizando um faturamento de US\$ 425 bilhões (Tabela 1). Em 2011, os EUA concentravam a maior parcela do consumo de produtos de beleza, atingindo $14,8 \%$ do total, contudo essa participação tem se retraído ao longo da última década. Países como o Brasil e a China têm apresentado significativo crescimento em relação aos demais mercados tradicionais e consolidados, como dos EUA, do Japão, da França e do Reino Unido (ABIHPEC, 2012). 
Tabela 1 - Principais Mercados de Consumo de Produtos Cosméticos, de Higiene Pessoal e Perfumaria em 2010

\begin{tabular}{|c|l|c|c|c|c|}
\hline \multicolumn{2}{|c|}{ Ranking Mundial } & $\mathbf{2 0 1 0}$ & $\mathbf{2 0 1 1}$ & $\begin{array}{c}\text { Crescimento } \\
(\%)\end{array}$ & $\begin{array}{c}\text { Participação } \\
\text { (\%) }\end{array}$ \\
\cline { 3 - 4 } & US\$ milhões & US\$ milhões & & 14,8 \\
\hline 1 & Estados Unidos & $60.744,0$ & $63.086,4$ & 3,9 & 11,1 \\
\hline 2 & Japão & $43.381,7$ & $47.267,7$ & 9,0 & $\mathbf{1 0 , 1}$ \\
\hline $\mathbf{3}$ & BRASIL & $\mathbf{3 6 . 1 8 6 , 9}$ & $\mathbf{4 3 . 0 2 8 , 5}$ & $\mathbf{1 8 , 9}$ & 6,5 \\
\hline 4 & China & $23.879,4$ & $27.704,3$ & 16,0 & 4,6 \\
\hline 5 & Alemanha & $17.730,3$ & $19.419,9$ & 9,5 & 4,1 \\
\hline 6 & França & $16.079,1$ & $17.294,7$ & 7,6 & 4,0 \\
\hline 7 & Reino Unido & $15.592,8$ & $17.019,8$ & 9,2 & 3,3 \\
\hline 8 & Rússia & $12.373,0$ & $14.187,0$ & 14,7 & 3,0 \\
\hline 9 & Itália & $12.158,1$ & $12.964,7$ & 6,6 & 2,6 \\
\hline 10 & Espanha & $10.473,3$ & $11.007,4$ & 5,1 & $\mathbf{6 4 , 1}$ \\
\hline \multicolumn{2}{|c|}{ Total dos 10 } & $\mathbf{2 4 8 . 5 9 8 , 6}$ & $\mathbf{2 7 2 . 9 8 0 , 4}$ & $\mathbf{9 , 8}$ & $\mathbf{9 , 8}$ \\
\hline \multicolumn{2}{|c|}{ Total Mundial } & $\mathbf{3 8 7 . 7 2 7 , 1}$ & $\mathbf{4 2 5 . 8 6 6 , 5}$ & $\mathbf{9 , 8}$ & \\
\hline
\end{tabular}

Fonte: Euromonitor, 2012.

No que diz respeito ao consumo do setor no Brasil, registre-se que, desde 2006, o país ocupa posição de destaque e o faturamento do setor vem apresentando significativo crescimento ao longo da década. Segundo a ABIHPEC, nos últimos 15 anos, a indústria brasileira cresceu 10,4\% e essa expansão é bastante significativa se comparada com outros setores industriais e o próprio PIB brasileiro. Enquanto o segmento de cosméticos obteve taxas de crescimento de 10,4\%, a indústria em geral alcançou 2,7\% e o PIB 3,1\% (IBGE, 2010).

Como apontado neste trabalho, o crescimento do mercado de consumo no Brasil está vinculado a uma série de fatores. Destacamos no capítulo anterior a importância e o impacto da esperança de vida da população no consumo de um modo em geral e, principalmente, do consumo de itens e serviços que envolvem a indústria da beleza. Além desse aspecto, um conjunto de fatores exerce influência direta na dinâmica do consumo desse setor, com destaque para o aumento da renda da população e da participação da mulher 
no mercado de trabalho, os novos nichos de mercado para diferentes públicos consumidores, o lançamento constante de novidades desse mercado, entre outros. Ademais, a expressiva participação do mercado de consumo nacional também se deve à operação de unidades produtivas de grandes empresas transnacionais no Brasil, como são os casos, por exemplo, da francesa L'Oréal, da anglo-holandesa Unilever, das estadunidenses Colgate-Palmolive, Johnson \& Johnson e Avon, entre outras.

O fortalecimento do mercado interno e o crescimento da renda de todas as classes e, sobretudo, das camadas mais pobres da população têm impactado diretamente os mercados de consumo no Brasil. O poder de compra das classes $C$ e $D^{4}$ representa a principal mudança desse fenômeno, sendo esse novo cenário ainda mais expressivo no consumo dessa população urbana e, destaque-se, a propósito, o avanço desse padrão de consumo acima da média, particularmente, nas regiões Nordeste e Norte (MYATA, H., 2011).

A Fecomercio (Federação do Comércio do Estado de São Paulo), a partir dos cálculos previstos de crescimento do PIB, aponta que entre 2010 e 2013, as classes econômicas C, D e E apresentarão o dobro do crescimento no consumo de bens e serviços do que é esperado para as classes A e B. Por volta de 30 milhões de brasileiros migraram das classes D/E para a classe $C$ refletindo numa mudança de comportamento no consumo, bem como no destino final da renda dessa população. Nos últimos anos, observamos uma evolução no consumo de itens considerados não-essenciais, como do setor de vestuário, lazer e de produtos da indústria da beleza.

\footnotetext{
${ }^{4}$ Segundo a FGV (Fundação Getúlio Vargas), as classes econômicas ou de renda podem ser definidas do seguinte modo: Classe $E(0$ a $R \$ 705)$; Classe $D(R \$ 705$ a $R \$ 1.126)$; Classe $C$ $(R \$ 1.126$ a $R \$ 4.854) ;$ Classe $B(R \$ 4.854$ a $R \$ 6.329)$; e Classe $A$ ( $R \$ 6.329$ ou mais) (Dados a partir da PNAD e considerando a renda domiciliar mensal total de todas as rendas. In.: NERI, M. C., 2010).
} 
No que tange os cosméticos, o setor indica que as classes populares têm demandado cada vez mais o consumo de itens mais sofisticados. De acordo com a ABIHPEC (2010), essas classes apresentaram expressivo crescimento no consumo de produtos de higiene oral, especialmente de enxaguantes bucais, escovas de dente e fios dentais, como também xampu anticaspa (para homens), colorações para os cabelos (para mulheres) e perfumes.

Outro segmento que tem merecido destaque se refere ao consumo de produtos cosméticos por parte do público masculino. Esse segmento tem demonstrado avanços nos últimos anos no Brasil, alcançando o segundo maior mercado do mundo em produtos masculinos. Itens que antes eram considerados "luxos" para os homens passaram a ser produtos de uso corrente, como hidratantes, perfumes, xampus diferenciados e até mesmo os protetores solares que quase quadruplicaram especificamente nesse segmento de consumo (ABIHPEC, 2010).

Destaque-se, a propósito, o estudo ${ }^{5}$ desenvolvido por um grupo de pesquisadores da Texas Christian University que afirma que os gastos com produtos vinculados à aparência física, como cosméticos e vestuário, aumentam mesmo em períodos de recessão econômica e desemprego, seria o que denominaram de "efeito batom", ou seja, as pessoas desejam e continuam valorizando essas qualidades mesmo em fases de retração das atividades econômicas. A beleza sugere sensação de bem estar, um atributo que os indivíduos estão dispostos a pagar. Além disso, o estudo indica que a

\footnotetext{
${ }^{5} \mathrm{O}$ estudo norte-americano "Boosting Beauty in an Economic Decline: Mating, Spending, and the Lipstick Effect" (2012), publicado no "Journal of Personality and Social Psychology", relaciona dados econômicos dos últimos 20 anos com gastos em uma série de categorias de produtos nos EUA (LUCENA, R., 2012).
} 
população jovem, sobretudo as mulheres, representa a principal categoria de consumidores que mantêm esse comportamento e os produtos-alvo desse segmento, geralmente, são aqueles mais sofisticados e caros, apesar dos tempos de crise.

Dentre outros aspectos do mercado de consumo no país, destaca-se a categoria de perfumes. Atualmente, o Brasil tem o maior mercado de fragrâncias do mundo (perfumes, águas de colônia, colônia, sprays e vaporizadores para o corpo), ultrapassando os EUA que sempre estiveram na liderança do consumo desses itens (Gráfico 6). Em 2010, o mercado brasileiro movimentou mais de US\$ 6 bilhões, sendo que 93\% das vendas estiveram associadas aos produtos considerados populares/convencionais (lavanda, água de colônia) e apenas uma pequena parcela representou aqueles produtos mais diferenciados e sofisticados, (denominados premium). A Natura e $\mathrm{O}$ Boticário detêm $60 \%$ do mercado de consumo em perfumaria no Brasil, mas destaca-se a expressiva participação das grandes empresas transnacionais, como é o caso da estadunidense Avon, por exemplo.

\section{Gráfico 6 - Principais Mercados de Consumo de Fragrâncias no Mundo em 2009 e 2010 (milhões de US\$)}

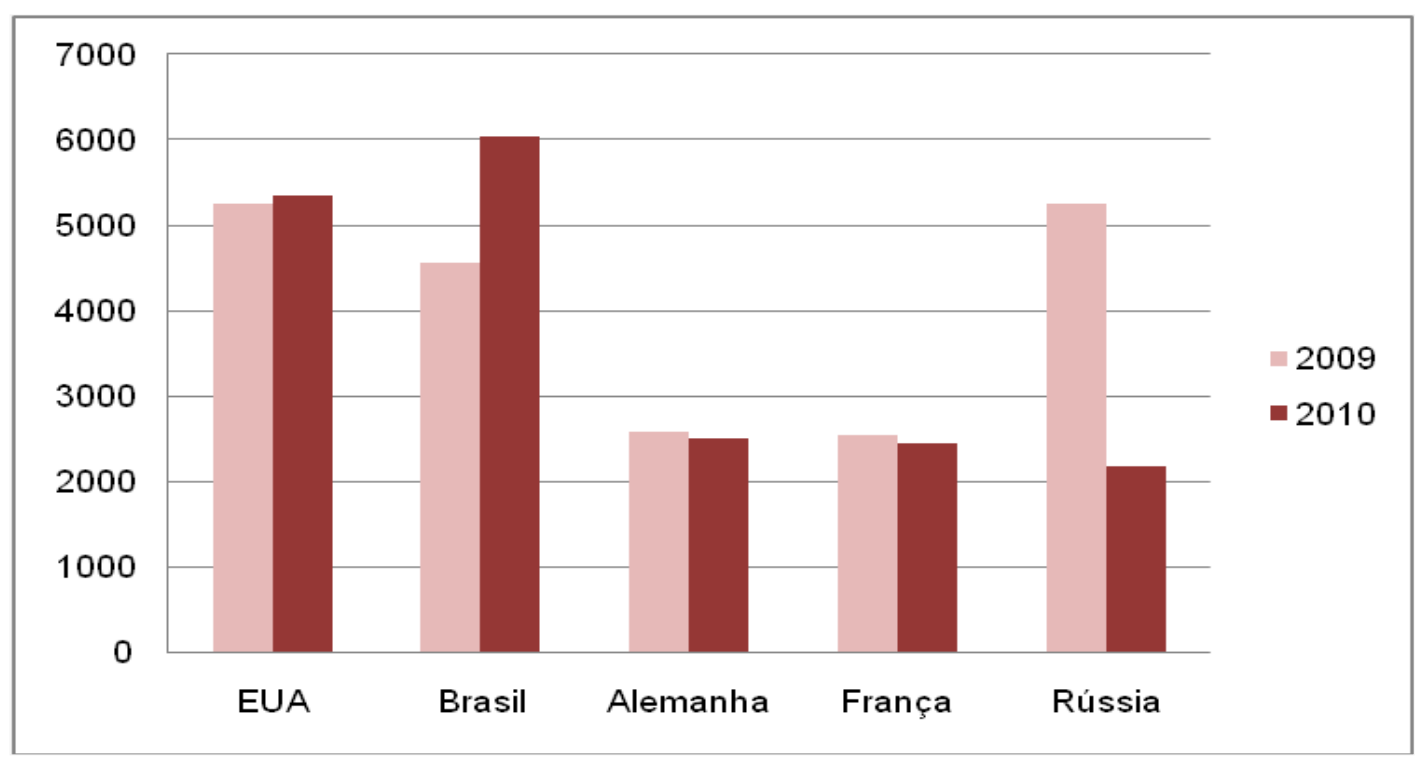


Além das fragrâncias, o Brasil detém também os maiores mercados de desodorantes, antitranspirantes e produtos infantis; o segundo mercado em produtos de cabelos, higiene oral, proteção solar, banho (sabonetes em barra, líquido e sais) e, ainda, produtos voltados especificamente para cuidados masculinos; o quarto, em cosméticos-cores (maquiagem, esmaltes, etc.); o quarto, em produtos destinados para a pele, e o quinto mercado em depilatórios (ABIHPEC, 2011).

Em 2011, os circuitos mundiais de exportação de bens finais e óleos essenciais do setor de cosméticos envolveram mais de US\$100 bilhões e um crescimento de $6 \%$ entre o período de 2007 e 2011. Por outro lado, o setor apresentou importante queda em 2009, certamente impactado pela a recessão econômica de 2008/2009. A Tabela 2 apresenta os principais exportadores mundiais, o valor das trocas comerciais, sua evolução e a participação no panorama da exportação mundial em 2011.

Tabela 2 - Principais Exportadores Mundiais de Óleos Essenciais, Perfumes, Cosméticos e Produtos de Higiene Pessoal em 2011 (milhões de US\$)

\begin{tabular}{|c|c|c|c|c|c|}
\hline Ranking & País & $\begin{array}{c}\text { Valor } \\
\text { Exportado }\end{array}$ & $\begin{array}{c}\text { Saldo } \\
\text { Comercial }\end{array}$ & $\begin{array}{l}\text { Crescimento } \\
\text { das Export. } \\
2007-2011 \text { (\%) }\end{array}$ & $\begin{array}{c}\text { Participação } \\
\text { nas } \\
\text { exportações } \\
\text { mundiais (\%) }\end{array}$ \\
\hline $1^{\circ}$ & França & 16.397 .784 & 10.852 .420 & 1 & 16,3 \\
\hline 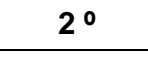 & Alemanha & 10.747 .827 & 4.573 .900 & 4 & 10,7 \\
\hline 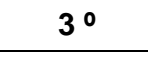 & EUA & 9.596 .696 & 456.788 & 5 & 9,5 \\
\hline 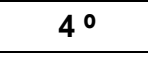 & Irlanda & 7.656 .729 & 6.534 .466 & 0 & 7,6 \\
\hline $5 \circ$ & Reino Unido & 5.662 .392 & -5.983 & 0 & 5,6 \\
\hline $6 \circ$ & Cingapura & 4.313 .233 & 1.956 .993 & 20 & 4,3 \\
\hline 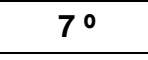 & Itália & 3.951 .287 & 736.522 & 3 & 3,9 \\
\hline 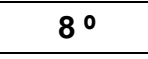 & Espanha & 3.697 .103 & 467.616 & 8 & 3,7 \\
\hline $9 \circ$ & Suíça & 3.184 .613 & 1.791 .066 & 6 & 3,2 \\
\hline 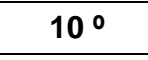 & Bélgica & 3.090 .905 & 715.680 & 12 & 3,1 \\
\hline $11^{\circ}$ & China & 3.029.071 & 1.090 .063 & 14 & 3 \\
\hline 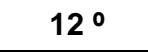 & Holanda & 2.883 .890 & 40.750 & 3 & 2,9 \\
\hline
\end{tabular}




\begin{tabular}{|l|l|c|c|c|c|}
$\mathbf{1 3} \cong$ & Polônia & 2.610 .008 & 678.935 & 12 & 2,6 \\
\hline $\mathbf{1 4} \cong$ & México & 2.036 .462 & 153.509 & 12 & 2 \\
\hline $\mathbf{1 5} \cong$ & Japão & 1.977 .596 & -1.084 .698 & 15 & 2 \\
\hline $\mathbf{1 6} \cong$ & Tailândia & 1.835 .687 & 863.937 & 19 & 1,8 \\
\hline $\mathbf{1 7} \cong$ & Canada & 1.642 .001 & -1.164 .737 & 5 & 1,6 \\
\hline $\mathbf{1 8} \cong$ & Hong Kong & 1.315 .681 & -1.483 .551 & 16 & 1,3 \\
\hline $\mathbf{1 9} \cong$ & Coréia do Sul & 8608.77 & -599.469 & 29 & 0,9 \\
\hline $\mathbf{2 0} \cong$ & Índia & 830.224 & 371.777 & 10 & 0,8 \\
\hline $\mathbf{2 1} \cong$ & Brasil & 823.013 & 4119 & 11 & 0,8 \\
\hline $\mathbf{2 2} \cong$ & Argentina & 817.237 & 299.210 & 13 & 0,8 \\
\hline & Total & $\mathbf{1 0 0 . 5 3 5 . 4 8 5}$ & $\mathbf{4 . 2 0 5 . 9 2 0}$ & $\mathbf{6}$ & $\mathbf{1 0 0}$ \\
\hline
\end{tabular}

Fonte: COMTRADE, 2012. Elaborado pela Autora.

Os principais países de exportação de produtos cosméticos são representados por aqueles com tradição no segmento, sobretudo por alguns da União Europeia, com destaque para a França (US\$ 16,3 bilhões) que centraliza $16 \%$ das exportações mundiais, em seguida a Alemanha (US $\$ 10,7$ bilhões) e os EUA (US\$ 9,5 bilhões). O Brasil ocupa a $21^{\circ}$ posição no ranking mundial e detém apenas $0,8 \%$ das exportações, entretanto registre-se significativa expansão nos últimos anos com $11 \%$ de crescimento nesses fluxos comerciais. A Índia, México, Cingapura, Coréia do Sul e Tailândia também são outros países que têm apresentado crescimento nas exportações mundiais. Além dos exportadores em destaque, ressalta-se a participação de outros países no comércio mundial, como Colômbia, Malásia, Indonésia, Turquia e África do Sul. Essa dinâmica ilustra as novas tendências do mercado de exportação de cosméticos, onde os 'países emergentes' demonstram ampliação de seus processos produtivos in loco e consequente expansão na participação dos fluxos internacionais (MAPA 1). 


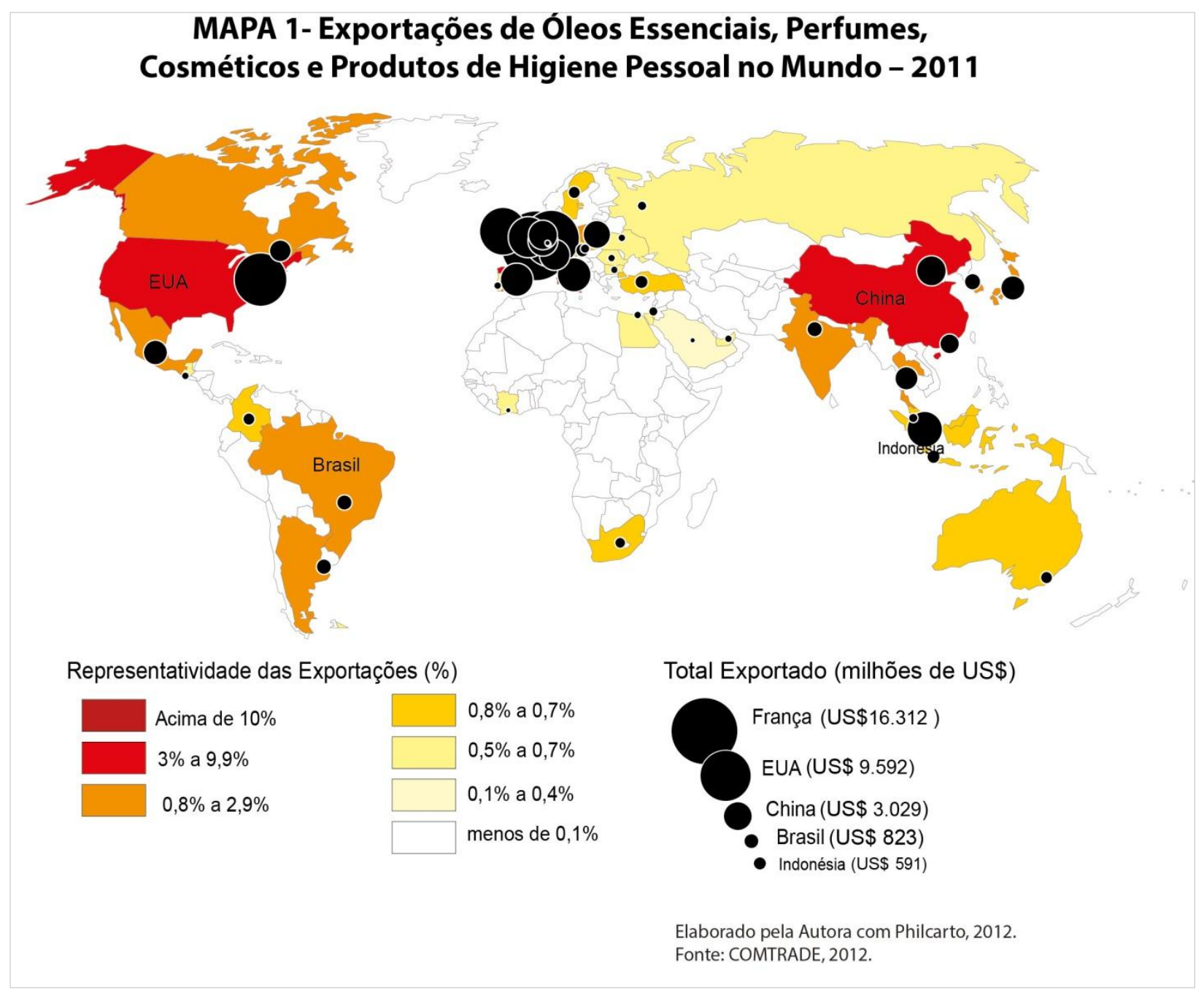

Em relação à importação desses produtos, os maiores países exportadores também são em sua maioria os principais importadores de cosméticos, destacando novamente o peso dos países líderes nesse setor. 0 grupo dos maiores importadores mundiais é formado pelos EUA (US\$ 9,1 bilhões) com quase $10 \%$ do total importado, Alemanha (US\$ 6,1 bilhões), Reino Unido (US\$ 5,6 bilhões) e França (US\$ 5,5 bilhões). Mesmo com os altos valores de importação, esses países apresentam saldos comerciais positivos, principalmente, a França, com mais de US\$10 bilhões de superávit (Tabela 3). 
Tabela 3 - Principais Importadores Mundiais de Óleos Essenciais, Perfumes, Cosméticos e Produtos de Higiene Pessoal em 2011 (milhões de US\$)

\begin{tabular}{|c|c|c|c|c|c|}
\hline Ranking & País & $\begin{array}{c}\text { Valor } \\
\text { Importado }\end{array}$ & $\begin{array}{c}\text { Saldo } \\
\text { Comercial }\end{array}$ & $\begin{array}{c}\text { Crescimento } \\
\text { das Import. } \\
2007-2011(\%)\end{array}$ & $\begin{array}{l}\text { Participação nas } \\
\text { Importações } \\
\text { mundial (\%) }\end{array}$ \\
\hline 10 & EUA & 9.139 .908 & 456.788 & 3 & 9,5 \\
\hline $2 \circ$ & Alemanha & 6.173 .927 & 4.573 .900 & 3 & 6,4 \\
\hline 3 웅 & Reino Unido & 5.668 .375 & -5.983 & 1 & 5,9 \\
\hline 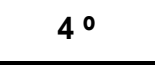 & França & 5.545 .364 & 10.852 .420 & 4 & 5,8 \\
\hline 5 ㅇ & Rússia & 3.404 .765 & -3.107 .581 & 7 & 3,5 \\
\hline 60 & Espanha & 3.229 .487 & 467.616 & 3 & 3,4 \\
\hline $7 \stackrel{0}{-}$ & Itália & 3.214 .765 & 736.522 & 0 & 3,3 \\
\hline 80 & Japão & 3.062.294 & -1.084 .698 & 9 & 3,2 \\
\hline 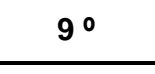 & Holanda & 2.843 .140 & 40.750 & 2 & 3 \\
\hline $10^{\circ}$ & Canadá & 2.806 .738 & -1.164 .737 & 4 & 2,9 \\
\hline 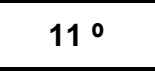 & Hong Kong (SAR) & 2.799 .232 & -1.483 .551 & 16 & 2,9 \\
\hline 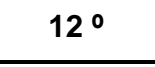 & Bélgica & 2.375 .225 & 715.680 & 4 & 2,5 \\
\hline 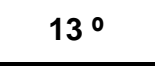 & Cingapura & 2.356 .240 & 1.956 .993 & 10 & 2,4 \\
\hline $14 \stackrel{\circ}{1}$ & China & 1.939 .008 & 1.090 .063 & 23 & 2 \\
\hline 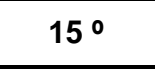 & Polônia & 1.931 .073 & 678.935 & 7 & 2 \\
\hline 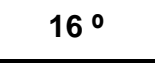 & México & 1.882 .953 & 153.509 & 5 & 2 \\
\hline $17^{\circ}$ & E. Arábes & 1.806 .574 & -1.652 .343 & 8 & 1,9 \\
\hline $18 \stackrel{\circ}{\circ}$ & Coréia do Sul & 1.460 .346 & -599.469 & 10 & 1,5 \\
\hline 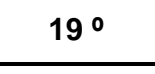 & Austrália & 1.418 .854 & -906.765 & 8 & 1,5 \\
\hline 20 & Suíça & 1.393 .547 & 1.791 .066 & 6 & 1,4 \\
\hline $31^{\circ}$ & Brasil & 818.894 & 4.119 & 20 & 0,9 \\
\hline \multicolumn{2}{|c|}{ TOTAL MUNDIAL } & 96.329 .565 & 4.205 .920 & 5 & 100 \\
\hline
\end{tabular}

Fonte: COMTRADE, 2012. Elaborado pela Autora.

O Brasil apresenta valores de importação de US\$ 818 milhões e aparece na $31^{\text {a }}$ posição dos principais países importadores de produtos do setor. Dentre os principais atores envolvidos, o Brasil apresenta a segunda maior taxa de crescimento de importações entre 2007 e 2011. No entanto, destaque deve ser 
dado a melhoria de sua balança comercial, já que há uma década atrás apresentava saldos negativos (ABIHPEC, 2012; MAPA 2).

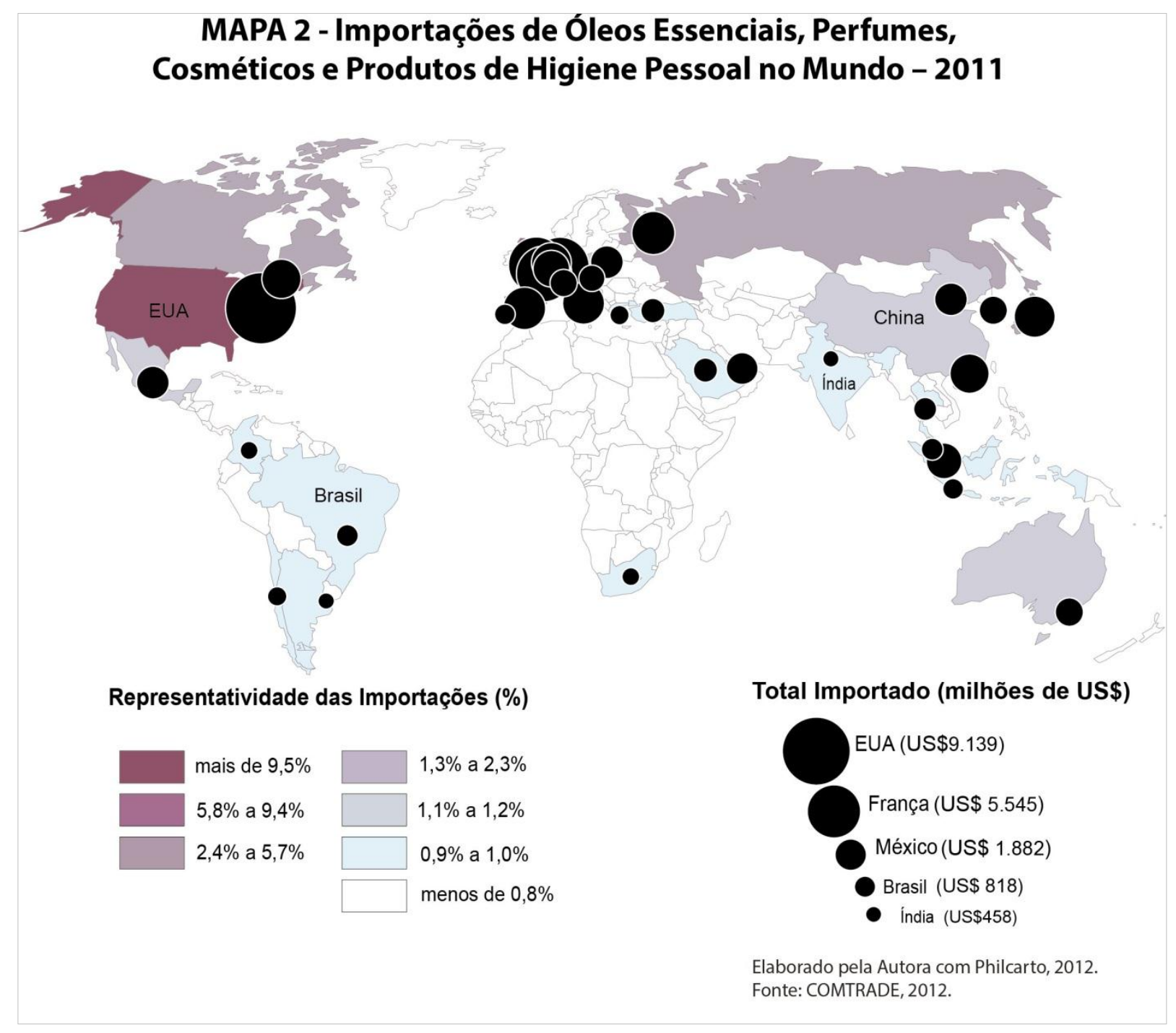

Em relação ao mercado de exportação brasileiro, o país exportou em perfumes, óleos essenciais, cosméticos e produtos de higiene pessoal cerca de US\$704 milhões em 2010, apresentando um superávit de US\$37 milhões. Os principais destinos das exportações têm sido os países da América do Sul, com destaque excepcional para o mercado argentino. Os dados de comércio exterior apontam que a Argentina importou do Brasil mais de US\$173 milhões, representando $21 \%$ das trocas comerciais do setor para o exterior (Gráfico 7). 
Gráfico 7 - Destino das Exportações Brasileiras em Óleos Essenciais, Perfumes, Cosméticos e Produtos de Higiene Pessoal entre 2008 e 2011 (milhões de US\$)

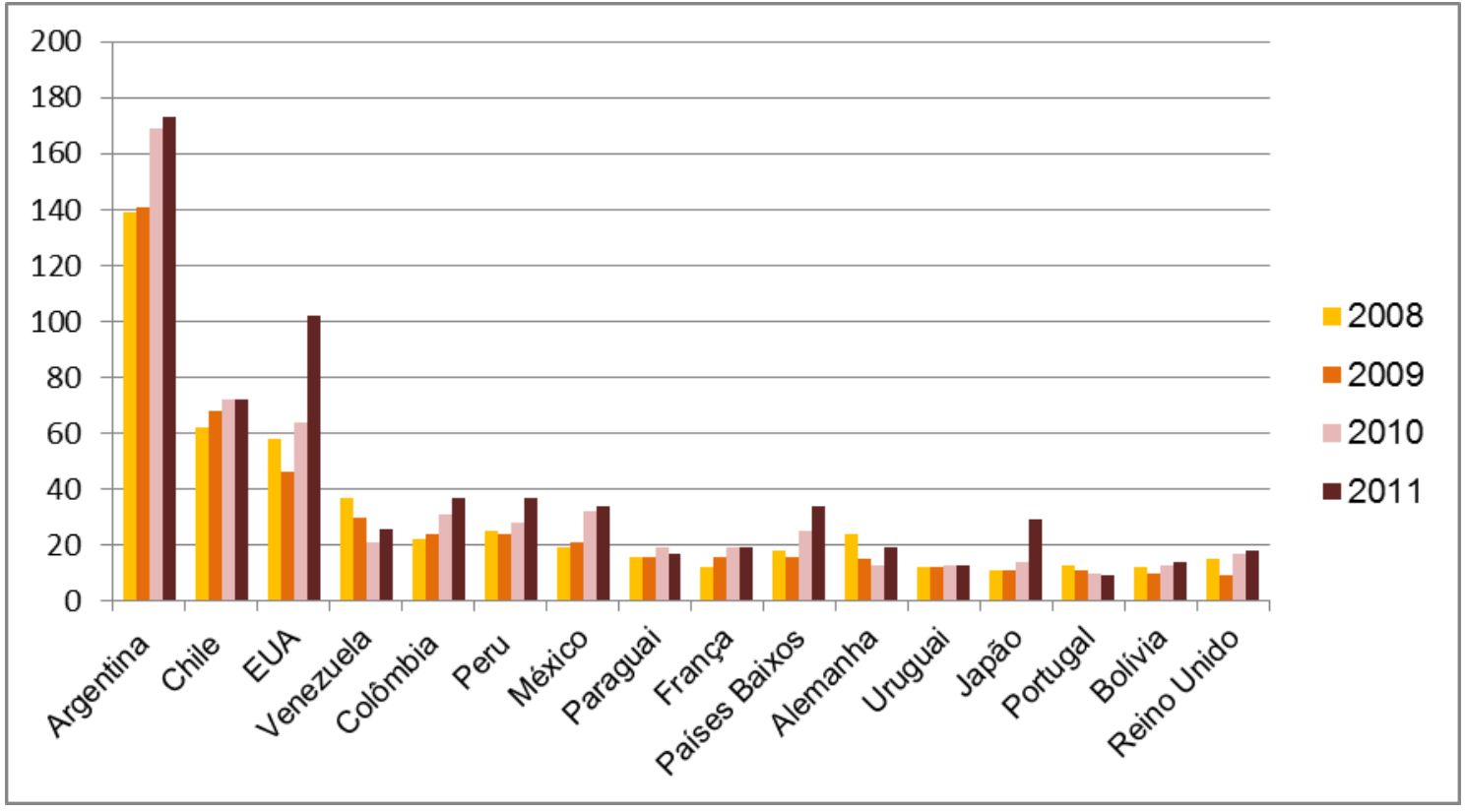

Fonte: MDIC; COMTRADE, 2012. Elaborado pela Autora.

Dentre outros fatores, o crescimento das exportações brasileiras está associado à ampliação da produção no país para o atendimento do mercado interno e externo, aos investimentos em inovação tecnológica, sobretudo das grandes indústrias líderes que detém plantas industriais de produção no Brasil e das principais empresas nacionais, como a Natura e O Boticário. Além disso, algumas parcerias entre a associação representativa do setor industrial e a agência de promoção de exportações (Apex) têm funcionado como importante alavanca para atrair investidores estrangeiros e também incentivar o aumento das exportações, principalmente das pequenas e médias empresas que apresentam sua produção restrita ao mercado nacional (ABDI, 2009).

Em contrapartida, ainda existem diversos entraves para a expansão das exportações brasileiras tendo em vista justamente as dificuldades enfrentadas pelas indústrias de pequeno e médio porte $(90 \%$ das indústrias atuantes no país) tanto na adoção das rigorosas exigências internacionais de qualidade e 
normatização como também em relação a sua capacidade de inovação, contribuindo em média por apenas $2 \%$ do valor total das exportações (SEBRAE, 2009).

As exportações do país estão concentradas nos óleos essenciais, considerando que o Brasil concentra significativa parte das exportações no fornecimento de matérias-primas brutas ou semiprocessadas também neste setor (Gráfico 8). Além dos produtos de higiene pessoal, como xampus, condicionadores e outras preparações capilares (42\% do total são exportados para a Argentina), sabonetes e cremes dentais também formam o grupo de produtos de grande representatividade das exportações nacionais, sobretudo pela atuação das grandes empresas instaladas no país para atender o mercado regional (GARCIA, 2005).

\section{Gráfico 8 - Representatividade das Exportações Brasileiras em 2011}

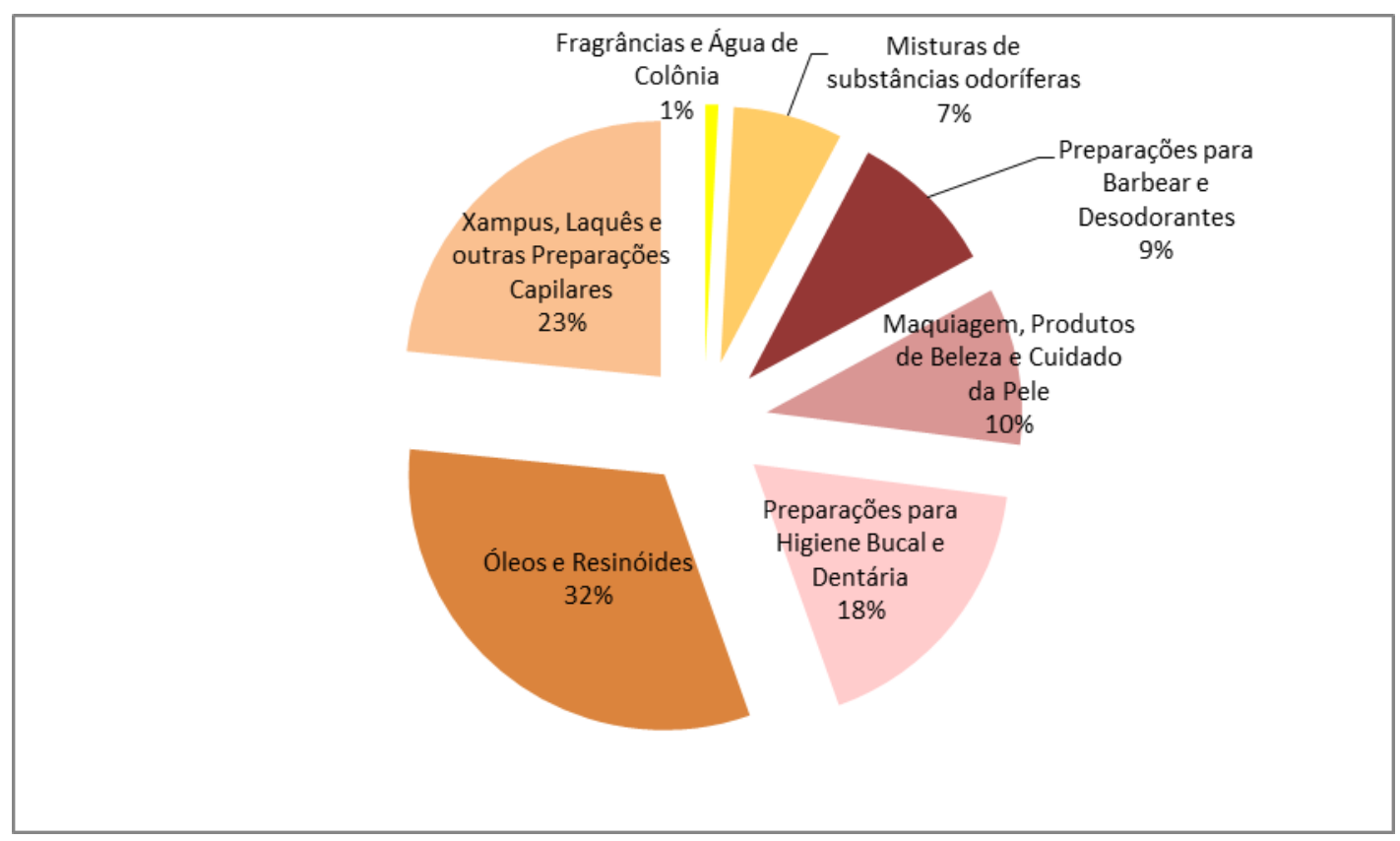

Fonte: MDIC, 2012; COMTRADE, 2012. Elaborado pela Autora.

Quanto ao cenário das importações brasileiras no segmento específico dos cosméticos, o abastecimento dos diversos produtos de bens finais, 
principalmente dos mais sofisticados e de menor consumo interno é composto, sobretudo por importações dos grandes países produtores e, em sua maioria, provenientes dos Estados Unidos (17\%) e da França (16\%). No entanto, o principal parceiro nestas relações comerciais é também o país que mais importa produtos do Brasil, isto é, a Argentina, um fato que também certamente está relacionado ao papel desempenhado pelos mecanismos vigentes no âmbito do Mercosul. (Gráfico 9).

Gráfico 9 - Origem das Importações Brasileiras em Óleos Essenciais, Perfumes, Cosméticos e Produtos de Higiene Pessoal entre 2008 e 2011 (milhões de US\$)

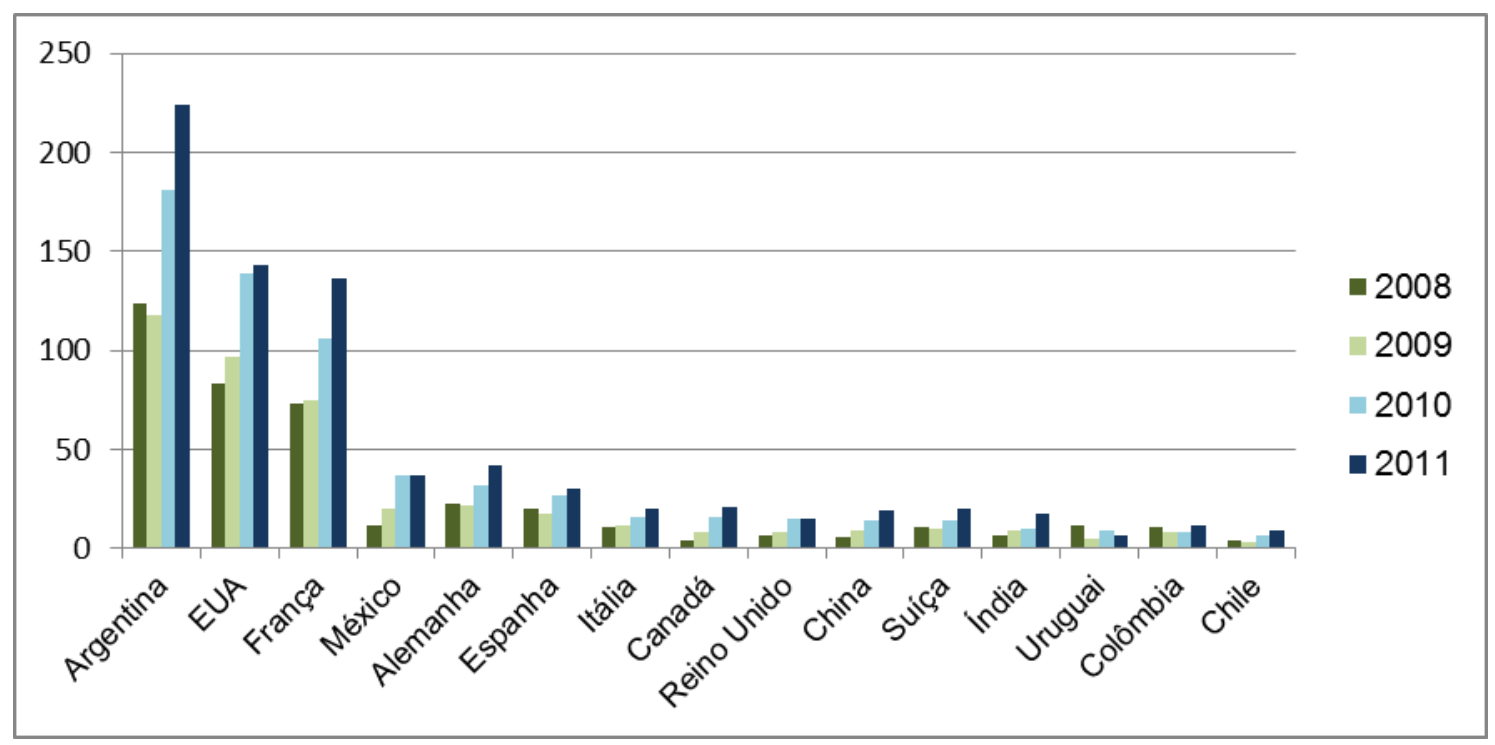

Fonte: MDIC, 2012; COMTRADE, 2012. Elaborado pela Autora.

Os itens do setor com maior entrada no país são os desodorantes corporais que representam sozinhos $28 \%$ do total das importações e diz respeito ao grande volume de itens de higiene pessoal. Além dos desodorantes, as loções pós-barba são predominantemente fabricados nas plantas industriais portenhas e exportados para o Brasil (84\% desses tipos de produtos que chegam ao Brasil são produzidos na Argentina). Os produtos de beleza, cuidado da pele, maquiagem e fragrâncias também se destacam nas importações brasileiras, sendo a França o maior fornecedor dessa categoria de produtos (Gráfico 10). 
Gráfico 10 - Representatividade das Importações Brasileiras em 2011

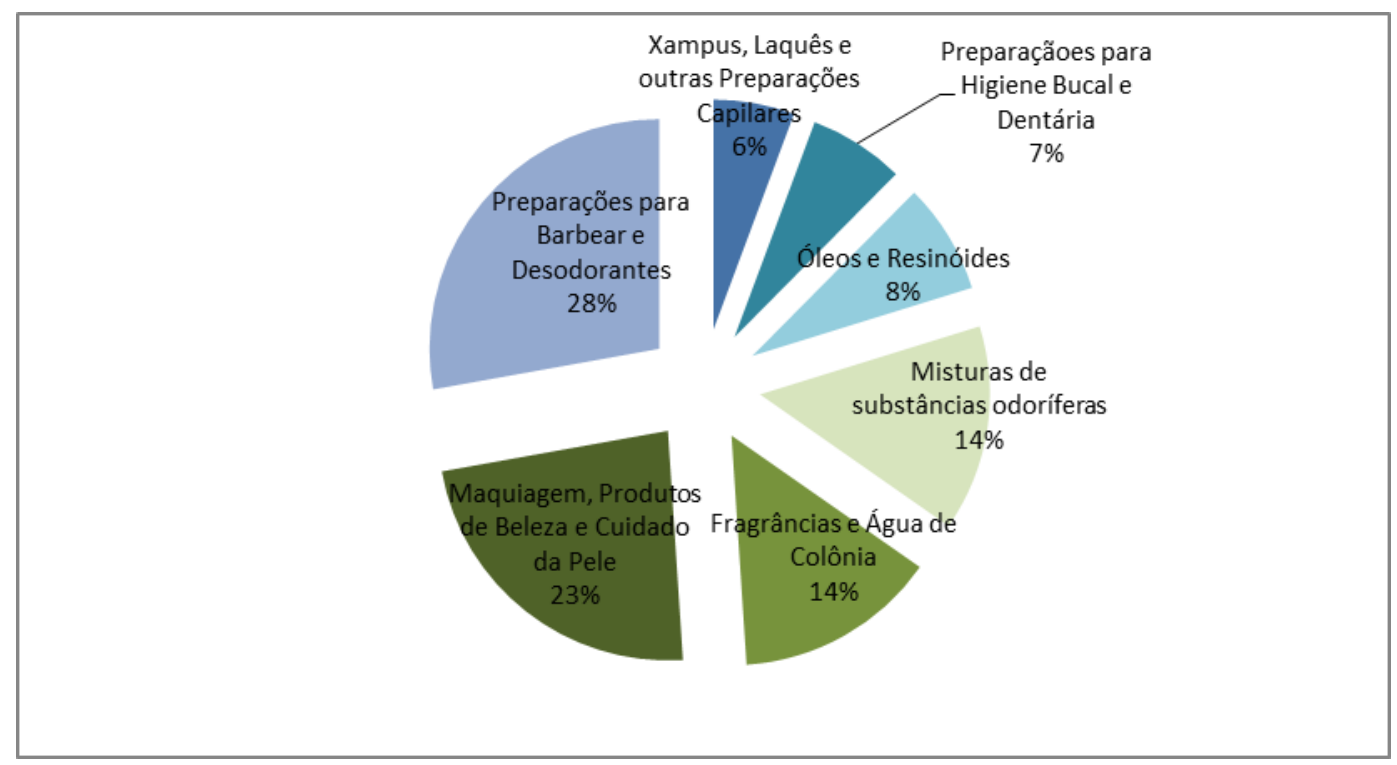

Fonte: MDIC, 2012; COMTRADE, 2012. Elaborado pela Autora.

Uma rápida avaliação nos quadros de exportações/importações do Brasil também revela que o país apresenta saldos negativos com alguns parceiros comerciais, especialmente com a França e os EUA. Além da importação dos produtos mais diferenciados e de alto valor agregado dos principais países produtores, o Brasil também abastece seu mercado doméstico por meio de importações de países de menor tradição no desenvolvimento de cosméticos (EUROMONITOR, 2012).

\subsection{O Panorama Internacional}

Dentre as cem maiores indústrias produtoras de cosméticos no mundo, os EUA concentram a maior parte delas, totalizando trinta e três grandes indústrias (Procter \& Gamble, Estée Lauder, Avon, Johnson \& Johnson, Coty, Mary Kay, etc); em segundo, a França com treze (L'Oréal, Chanel, LVMH, Yves Rocher, Clarins, Pierre Fabre, L'Occitane, etc); em terceiro lugar, o Japão 
com onze indústrias (Shiseido, KAO, Kose, Pola Orbis, Lion, dentre outras); em quarto, a Itália com dez (Euroitalia Cavenago, Bottega Verde, Micys, etc); a Alemanha, em quinto, com oito (Beiersdorf - Nívea, Vorwerk, Maurer \& Wirtz, etc); em sexto, o Reino Unido com sete (Unilever, Lornamead, Reckitt, Lush, etc); Suíça, Coréia do Sul e o Brasil concentram três cada um desses países; a Rússia, duas; e, finalmente, a China, a Bélgica, a Finlândia, a Letônia, a Espanha, a Suécia e o Peru dêtém uma indústria cada um ${ }^{5}$ (Gráfico 11).

\section{Gráfico 11 - Distribuição da Indústria de Cosméticos no Mundo em 2009}

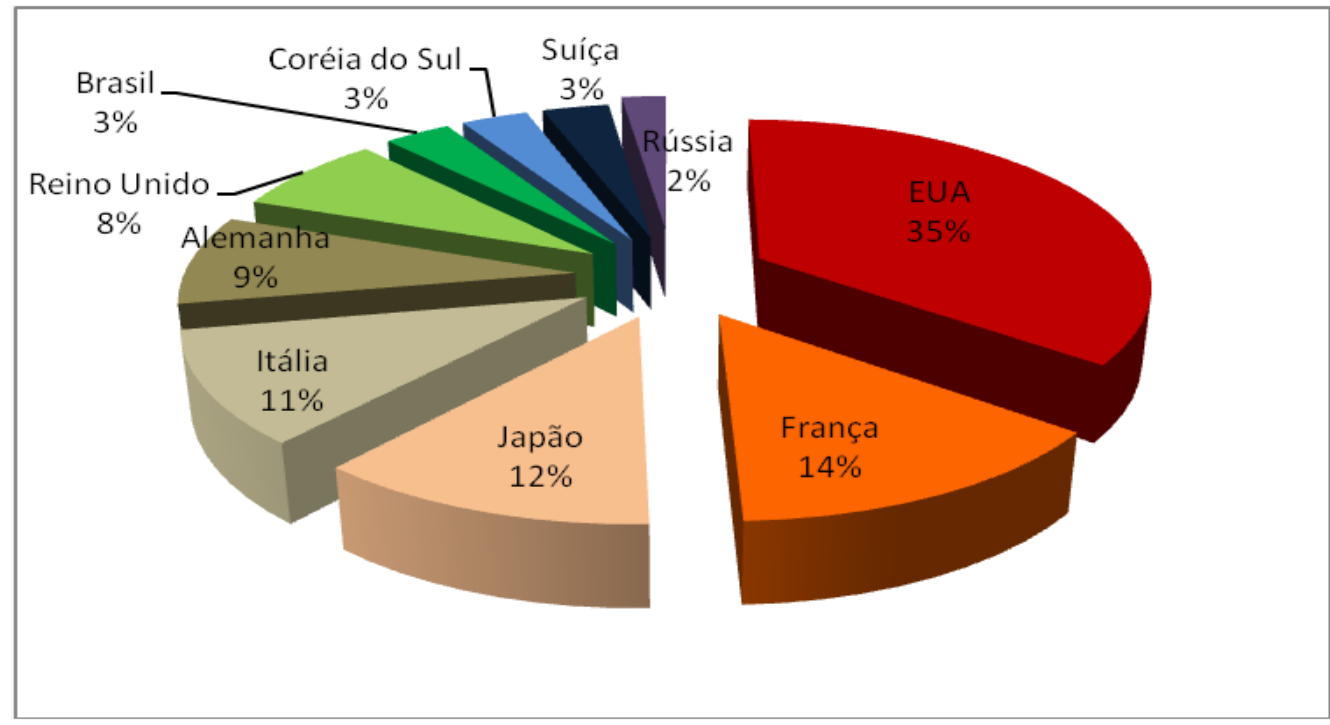

Fonte: WWD, 2009. Elaborado pela autora. Obs: China, Espanha, Bélgica, Suécia, Finlândia, Letônia e Peru detém 1\% cada.

Conforme citado anteriormente, parte dessas indústrias tem atuação voltada para o desenvolvimento e inovação de produtos específicos vinculados ao segmento de cosméticos, tendo como estratégia de comercialização as lojas especializadas em perfumaria e cosméticos. Já a outra parte trabalha com o segmento de higiene e limpeza, com produtos fabricados em larga escala, mais

\footnotetext{
${ }^{5}$ Considerada a comercialização de perfumes, maquiagem, produtos para o cuidado da pele (protetores, cremes anti-celulite), produtos para cabelo e desodorantes. Não inclui sabonetes em barra, lâminas de barbear, cremes dentais, detergentes, e outros produtos correlatos que são desenvolvidos por algumas dessas indústrias, como alimentos dietéticos, medicamentos e vitaminas.
} 
difundidos, e normalmente comercializados no varejo (farmácias, grandes departamentos e supermercados). As indústrias focadas na produção exclusiva e desenvolvimento de essências, fragrâncias e embalagens diferenciadas para produtos cosméticos e perfumaria são denominadas empresas de atuação concentrada (GARCIA, R., 2005). A L'Oréal, Estée Lauder, Avon, Chanel, Revlon, Shiseido e Natura são as grandes indústrias representativas desse tipo de atividade e que apresentam produtos mais inovadores, muitos deles sofisticados e com maior valor agregado se comparado às linhas de produtos desenvolvidas pelo segmento de higiene pessoal.

As indústrias classificadas como 'diversificadas' destinam a maior parte da produção ao desenvolvimento de produtos de higiene e limpeza e estão associadas com outras áreas correlatas, como 0 setor de produtos farmacêuticos e de alimentos, dentre elas, a anglo-holandesa Unilever e as estadunidenses Procter \& Gamble, Johnson \& Johnson e Colgate-Palmolive, que apresentam elevados graus de diversificação dos produtos.

O ranking das maiores empresas do setor é formado em sua maioria por empresas norte-americanas, francesas e japonesas (Anexo 3), com destaque para a posição da brasileira Natura nesse competitivo segmento industrial. $\mathrm{O}$ Gráfico 12 apresenta as quinze líderes mundiais quanto ao faturamento em 2008. 


\section{Gráfico 12 - Indústrias Líderes do Setor no Mundo em 2008}

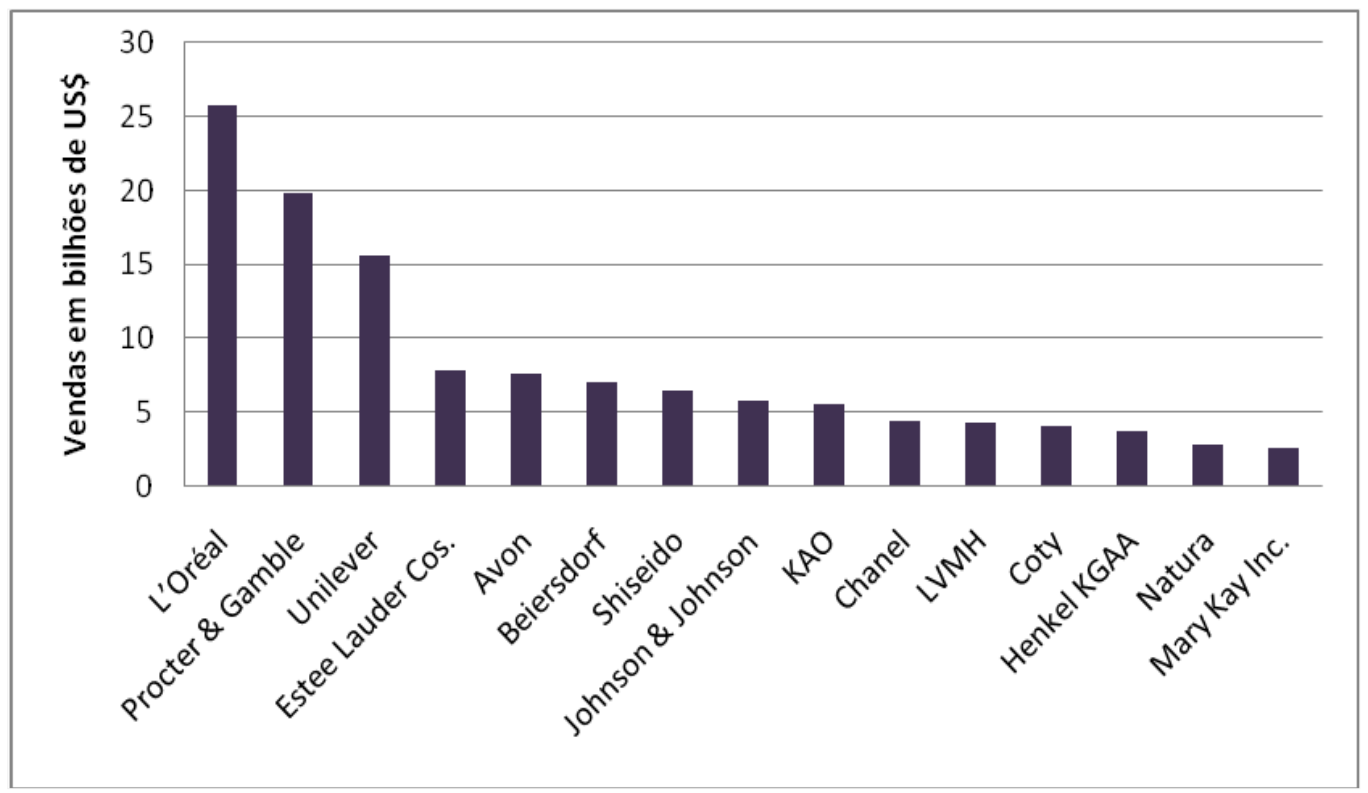

Fonte: WWD, 2009. Elaborado pela autora.

A L'Oréal é a maior indústria de cosméticos do mundo e participa com destaque significativo no mercado dos produtos denominados "premium" e também de produtos capilares. A empresa agrupa um extenso ramo de divisões e marcas, tendo como produtos para o grande público, a L'Oréal Paris, Garnier e Maybelline; como também produtos de luxo com as marcas Lancôme, Helena Rubinstein, Armani, Ralph Lauren, Biotherm, Yves Saint Laurent, Giorgio Armani, Cacharel, Diesel, entre outras; possui uma divisão cosmética ativa vinculada a importantes laboratórios de P\&D com a La RochePosay, Vichy e Innéov; e também os produtos profissionais-especializados destinados principalmente aos spas, clínicas e salões de beleza. Esse quadro demonstra o fortíssimo poder e o alto grau de capilaridade que a L'Oréal possui e que the permite, desse modo, atingir diversas camadas do mercado de consumo dos cosméticos.

Dentre as líderes de mercado, a estadunidense Avon, uma das indústrias de maior faturamento do setor, tem como característica a 
comercialização de seus produtos pelo canal de vendas diretas. Já a japonesa Shiseido, fundada em 1872, é uma das empresas mais antigas e especializada em produtos de alta tecnologia e é responsável pela comercialização das marcas de perfumes Jean Paul Gaultier e Narcizo Rodriguez.

O grupo Procter \& Gamble reúne grande conglomerado de empresas de diversos ramos e com uma gama bastante extensa de produtos e marcas. Ao longo da sua trajetória, adquiriu uma grande indústria de cosméticos, a Wella, e forma atualmente o maior grupo de empresas de bens de consumo do mundo, representando também linhas de perfumaria de marcas de luxo, como a Gucci, Lacoste, Hugo Boss, D\&G, entre outras.

A Johnson \& Johnson também atua na área de cosméticos e de higiene pessoal, dedicando-se especialmente ao desenvolvimento de linhas de produtos para a população infantil e de cuidados da pele.

Além das indústrias de produtos acabados, destacam-se as grandes indústrias produtoras de insumos químicos especializados, que fabricam desde ingredientes básicos a formulações de alta tecnologia e inovação. A produção desses tipos de insumo concentra-se majoritariamente na Alemanha devido a centralidadede grandes grupos líderes mundiais ali instalados, como a BASF, Evonik e Cognis ${ }^{6}$. Dentre outras indústrias dedicadas a produção e distribuição de ingredientes químicos para diversos setores industriais, incluindo a indústria de cosméticos, produtos de higiene e limpeza, destacam-se também as francesas Rhodia e Naturex; a inglesa Croda; a suíça Clariant, entre outras.

\footnotetext{
${ }^{6}$ A Cognis foi adquirida pela BASF em 2010 (BASF, 2012).
} 


\subsection{A Indústria de Cosméticos no Brasil}

Atualmente existem no Brasil 2.282 indústrias do setor de higiene pessoal, perfumaria e cosméticos (Mapa 3) e um balanço geral revela que as pequenas e médias empresas são predominantes no país. Ao mesmo tempo em que o setor é composto em sua maioria por indústrias de pequeno e médio porte, são as grandes empresas, e mais especificamente um grupo formado por 20 delas, que concentram $73 \%$ do faturamento global do setor no Brasil e um faturamento líquido acima dos $\mathrm{R} \$$ 100 milhões anuais (ABHIPEC, 2012).

MAPA 3 - Indústrias de Higiene Pessoal, Perfumaria e Cosméticos no Brasil

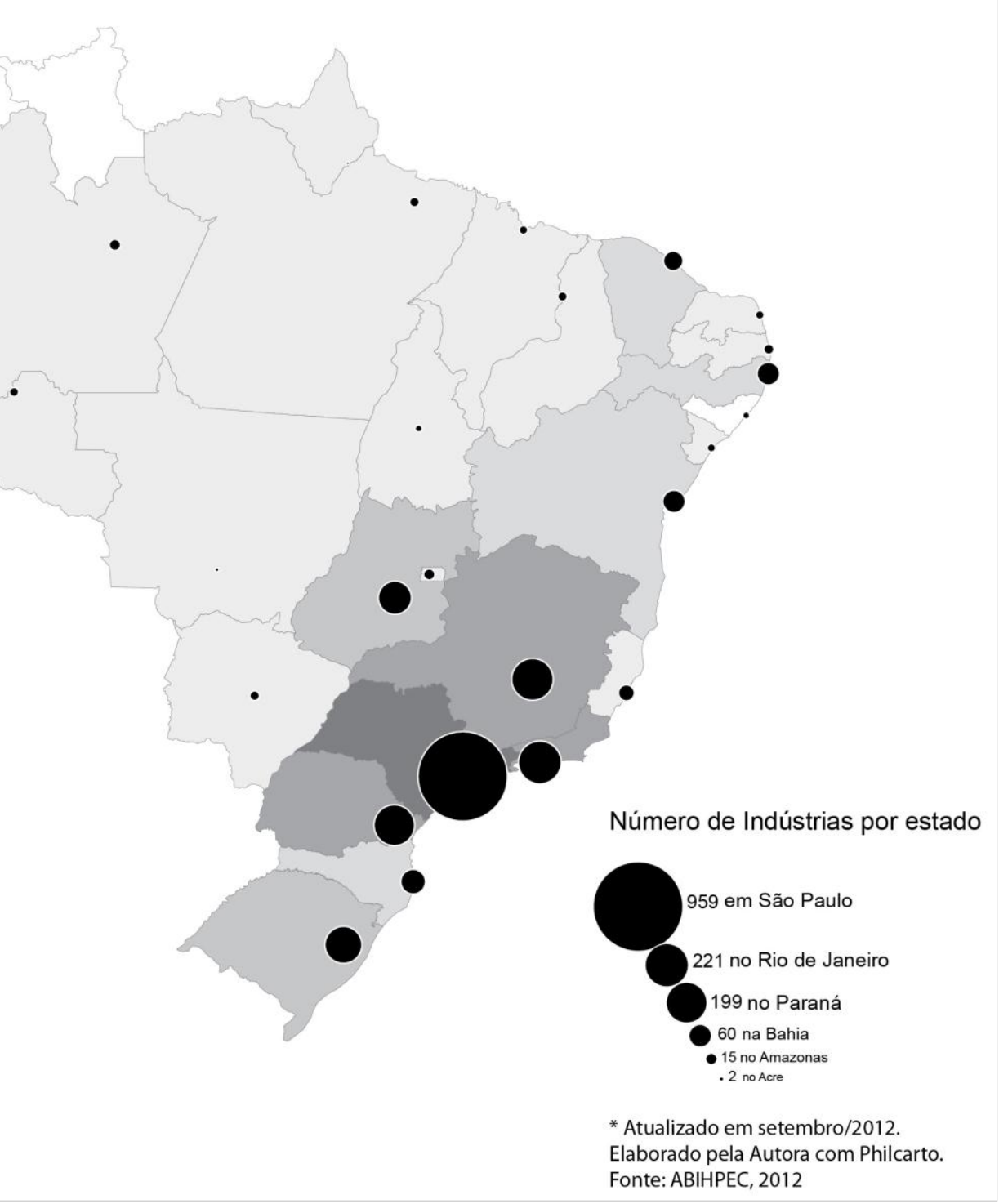


O setor encontra-se concentrado basicamente na região Sudeste, com 1.419 indústrias, seguida pela região Sul (436), Nordeste (222), Centro-Oeste (160) e Norte (45). O estado de São Paulo concentra $42 \%$ das indústrias de cosméticos instaladas no país e $67 \%$ das empresas da região Sudeste. Além disso, registre-se que a região Nordeste tem apresentado significativo crescimento no número de estabelecimentos ao longo da última década, sobretudo os estados da Bahia e de Pernambuco.

Destaque deve ser dado ao município de Diadema que tem implantado oficialmente um Polo Industrial de Cosméticos desde 2004, reunindo mais de uma centena de empresas de toda a cadeia produtiva, desde produtores de matérias-primas e insumos, como produtores de equipamentos, maquinário, embalagens, rótulos e distribuidores. O acordo para o estabelecimento do polo teve foi liderado pelo governo local e diversos parceiros, dentre eles, a ABIHPEC, a Agência de Desenvolvimento Econômico do Grande ABC, o Consorcio Intermunicipal do Grande ABC, o CIESP DIADEMA, SESI, SENAI e Fundação Florestan Fernandes. A ideia de criação esteve relacionada inicialmente na redução da violência urbana do município por intermédio da geração de vagas de emprego e aumento da renda local, como também na redução dos custos para aquisição de matérias-primas do setor (Lei Municipal № 2.237, de 23 de março de 2004).

O polo concentra cerca de $10 \%$ da produção do setor no país e agrupa atualmente mais de 100 empresas, desde microempresas a grandes grupos como a Davene, como outros fabricantes de produtos acabados e de matériasprimas (sobretudo insumos da indústria química). Quanto aos postos de trabalho, o polo emprega mais de 11 mil trabalhadores, sendo 8 mil diretos e 3 
mil indiretos e gera mais de $5 \%$ da arrecadação municipal (Prefeitura de Diadema, 2008).

O SEBRAE e SENAI contribuem na área de gestão e conformação do polo com bases para a formação de um Arranjo Produtivo Local ${ }^{7}$ (APL), apoio na geração de negócios, aperfeiçoamento técnico, treinamentos e consultorias. Dentre as atividades mais observadas no polo destaca-se a capacitação de profissionais dos diversos ramos do setor beleza, por exemplo, cursos de maquiagem, corte de cabelo, estética corporal e facial, depilação, entre outros (XAVIER, M.L.P. et al., 2007).

Apesar do Polo de Diadema integrar no mesmo município um conjunto de indústrias especializadas no mesmo setor produtivo, favo rendo o acesso a matérias-primas, equipamentos e concentração de mão de obra, registra-se que as empresas ali instaladas não se encontram sob uma rede de sistemas técnicos consolidados, carecem de infraestrutura e outros subsídios importantes no tocante das atividades industriais. Os principais aportes recebidos giram em torno de treinamentos ou encontram-se vinculados a aquisição conjunta de matérias-primas visando o barateamento dos custos para as empresas. É preciso reconhecer também que apesar da relevância da criação de um polo de cosméticos, no caso de Diadema, ele ainda carece de estratégias mais sólidas e de fortes incentivos no desenvolvimento de produtos inovadores e com maior valor agregado, como das atividades na área de P\&D que são extremamente essenciais nesse competitivo mercado. Conforme apontado por Hasenclever \& Zissimos (2006), esse fracasso pode estar

\footnotetext{
${ }^{7}$ Arranjos produtivos locais "são aglomerações territoriais de agentes econômicos, políticos e associais, com foco em um conjunto específico de atividades econômicas e que apresentam vínculos e interdependência" (ALBAGLI, S; BRITTO, J., 2002, p.3).
} 
vinculado à ausência de políticas setoriais e industriais mais adequadas na promoção desses tipos de aglomerações empresariais.

No que se refere ao crescimento médio da indústria brasileira de higiene pessoal, perfumaria e cosméticos, os dados dos últimos quinze anos apontam um crescimento em torno de 10\%, passando de um faturamento líquido de imposto sobre vendas, de $R \$ 4,9$ bilhões em 1996 para $R \$ 29,4$ bilhões em 2011 (ABIHPEC, 2012; Gráfico 13).

\section{Gráfico 13 - Evolução do Faturamento da Indústria de Higiene Pessoal, Perfumaria e Cosméticos no Brasil entre 1996 e 2011 (R\$ bilhões)}

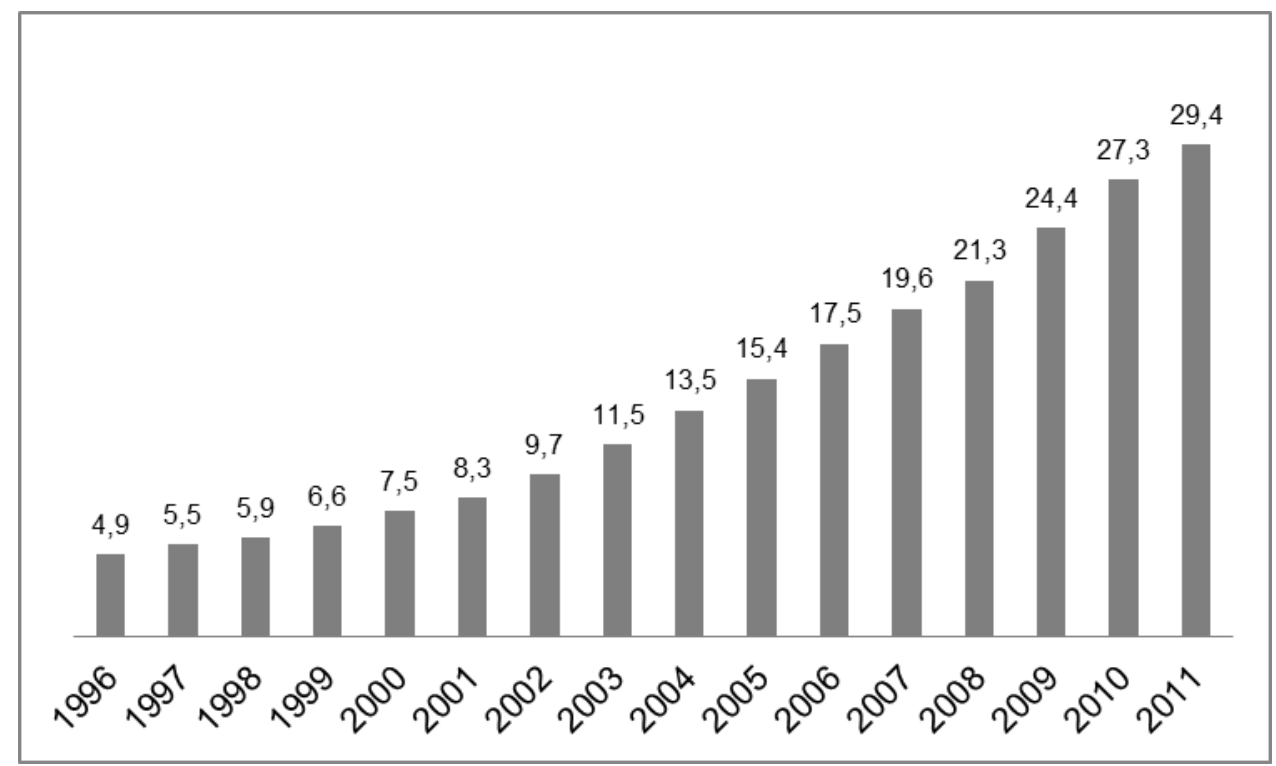

Fonte: ABIHPEC, 2012. Elaboração da Autora.

Quanto à classificação das empresas segundo o seu porte, a definição proposta pelo SEBRAE se baseia no número de pessoas ocupadas. Como o ramo dos cosméticos reúne em sua maioria pequenas empresas, adotamos as referências indicadas pelo SEBRAE por englobarem os principais perfis encontrados no setor. Sendo assim as microempresas são formadas por até 19 pessoas ocupadas; as pequenas empresas de 20 a 99 pessoas; as de médio porte de 100 a 499; e as grandes empresas com mais de 500 pessoas ocupadas. Desse modo, os dados da RAIS/IBGE (2008) indicam que o setor é 
composto por $75 \%$ de microempresas, seguido por empresas de pequeno porte com $19 \%$, empresas de médio porte representam apenas $5 \%$ e as grandes menos de $1 \%$ do total. Além disso, registre-se que mesmo que as empresas de grande porte detenham mais capacidade de geração de emprego, no setor de cosméticos é o grupo formado por empresas de médio porte que concentram as vagas do setor com $34 \%$ delas, seguido das pequenas com $26 \%$, as grandes com $25 \%$ e, por fim, as microempresas, que reúnem $14 \%$ do total.

No que se refere à geração de empregos, observamos importante dinamismo interno do setor e elevada capacidade de criação de postos de trabalho ao longo da última década (Tabela 4). Dentre os empregos relacionados ao setor, destacam-se os postos de trabalho associados à própria indústria e varejistas, como também as oportunidades de empregos indiretos com os salões de beleza, clínicas de estética, dermatologia, cirurgias plásticas e fisioterapia, spas e academias de ginásticas.

\section{Tabela 4 - Evolução do Emprego na Indústria de Cosméticos no Brasil entre 1994 e 2011}

\begin{tabular}{l|c|c|c|c}
\multicolumn{1}{c|}{ Segmento } & $\mathbf{1 9 9 4}$ & $\mathbf{2 0 1 1}$ & $\begin{array}{c}\text { Crescimento } \\
\text { em 17 anos (\%) }\end{array}$ & $\begin{array}{c}\text { Crescimento Médio } \\
\mathbf{2 0 1 1 / 1 9 9 4}(\%)\end{array}$ \\
\hline Indústria & 30 & 72 & 114,9 & 6,1 \\
\hline $\begin{array}{l}\text { Franquia } \\
\text { Vonsultora de }\end{array}$ & 11 & 139 & $1.164,5$ & 18,4 \\
\hline Venda Direta & 510 & 2.900 & 468,6 & 12,3 \\
\hline Salões de Beleza & 579 & 1.554 & 168,4 & 6,8 \\
\hline \multicolumn{1}{c}{ TOTAL } & $\mathbf{1 . 1 3 0}$ & $\mathbf{4 . 6 6 5}$ & $\mathbf{3 1 2 , 9}$ & $\mathbf{9 , 9}$ \\
\hline
\end{tabular}

Fonte: ABIHPEC, 2012. Elaboração da Autora.

Além disso, nos últimos anos sobressaem os trabalhos vinculados às etapas de comercialização final dos produtos com as revendedoras autônomas. Registre-se, também, que o grupo formado pela consultoria de venda direta (ou revendedoras) é constituído em sua maioria por uma mão de obra de baixa 
qualificação, sem horários fixos da jornada de trabalho e que não conta com qualquer tipo de vínculo trabalhista (GARCIA, R.; FURTADO, J., 2002). Esse grupo é composto predominantemente por mulheres que utilizam a comercialização de produtos como complementação da renda familiar.

Conforme apontado pela ABIHPEC (2012), os empregos vinculados ao setor estão fortemente concentrados na consultoria de venda direta, especialmente na venda de perfumes e produtos cosméticos (Gráfico 14). Os salões de beleza também reúnem significativa parcela de empregos dos profissionais envolvidos com o setor.

\section{Gráfico 14 - Distribuição da Mão de Obra empregada no Setor de Cosméticos em 2011}

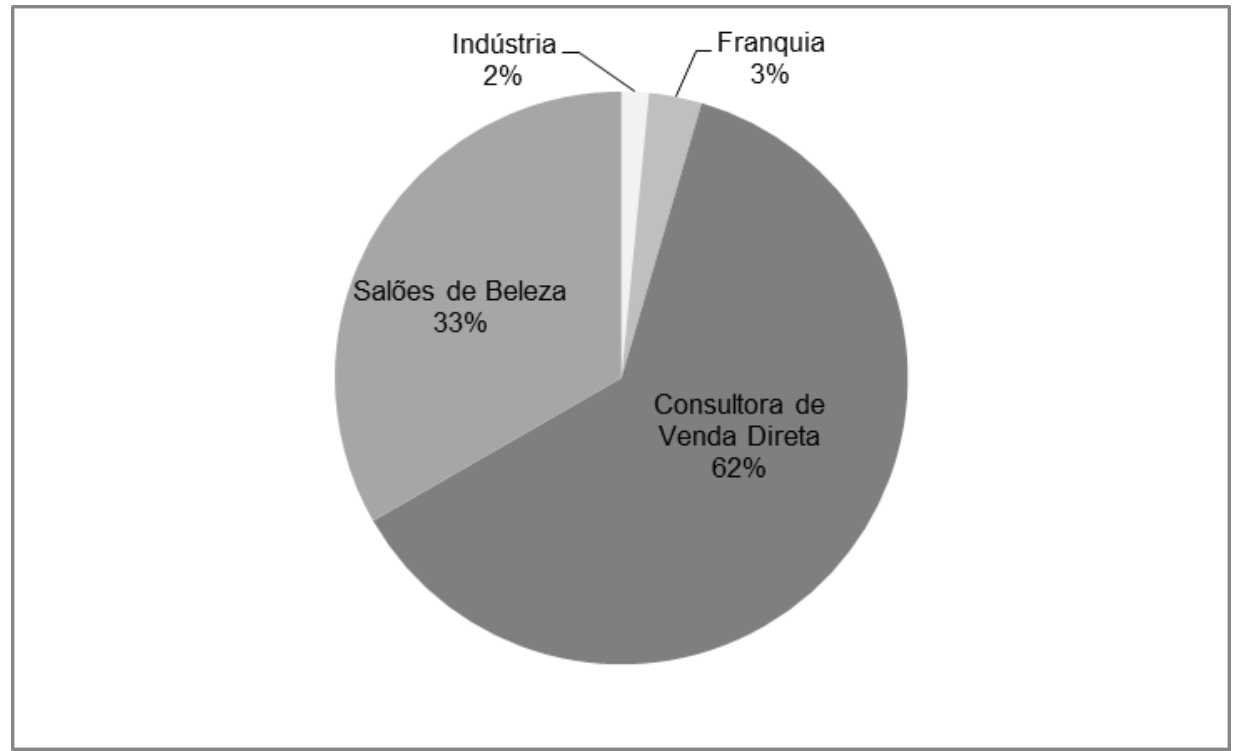

Fonte: ABIHPEC, 2012. Elaboração da Autora.

O estudo desenvolvido por Myata (2011) sobre o sistema de venda direta em indústrias de cosméticos e alimentos indica uma tendência das revendedoras autônomas de se alocar nos salões de beleza para ampliar suas vendas. A autora registra também que a venda direta adotada por algumas empresas de cosméticos tem criado uma capilaridade para alcançar o maior número de consumidores ao invés de expandir os negócios por meio de filiais 
espalhadas em diversas localidades do país. Além do mais, processos resultantes de uma intensa urbanização, expansão dos mercados de consumo e da competitividade empresarial têm levado a uma dinâmica territorial e a reorganização dos espaços produtivos dos grandes grupos líderes. A esse respeito, Myata analisa que:

"Essa dinâmica tem como corolário as transformações nos complexos produtivos industriais e na localização dos circuitos espaciais de produção e, não obstante, nos circuitos econômicos, fazendo com que uma nova racionalidade fosse implementada nos territórios produtivos, em busca da redução dos custos de produção e circulação, impulsionada por um conjunto de mudanças tecnológicas e informacionais, trazendo profundas repercussões na economia capitalista" (idem, p. 62).

Diversos grupos internacionais apresentam unidades produtivas no Brasil, operando com plantas indústrias em diversas localidades do país para abastecer tanto o mercado interno como o externo, especialmente os países integrantes do Mercosul. O grupo das indústrias líderes atua em sua maioria no amplo mercado doméstico e com fortes complementaridades em relação ao mercado regional, sendo formado pelas principais empresas do setor, como as gigantes L'Oréal, Procter \& Gamble, Unilever, Avon, Johnson \& Johnson, Shiseido, KAO, Coty, Colgate-Palmolive, entre outras. Essas indústrias concentram-se em maior parte no estado de São Paulo e compartilham $65 \%$ do mercado brasileiro com um seleto grupo de indústrias de capital nacional, 
dentre elas, a Natura, O Boticário e o grupo Hypermarcas (Gráfico 15; ver Anexo 4).

\section{Gráfico 15 - Participação da Indústria de Cosméticos no Mercado Brasileiro em 2009}

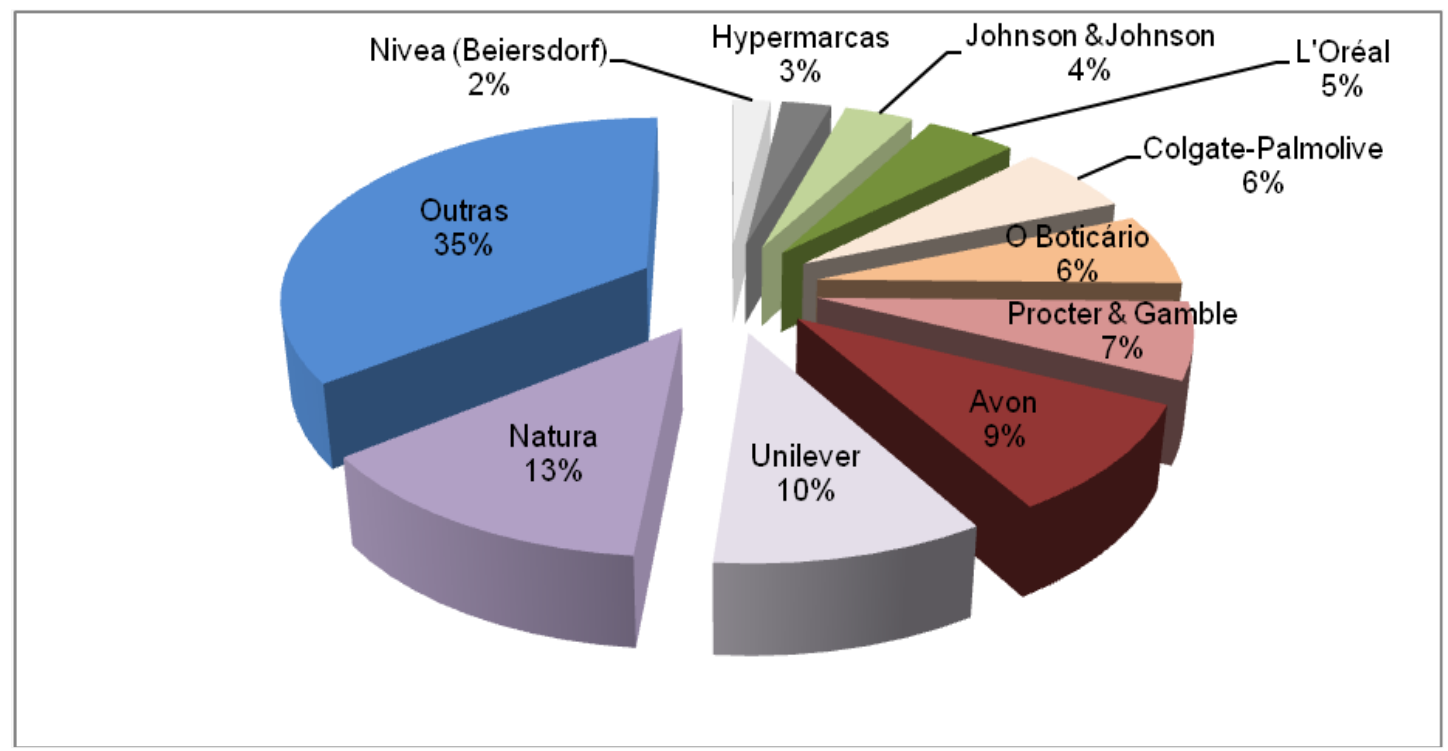

Fonte: EUROMONITOR In. Barclays Capital, 2011.

A Natura é atualmente a décima quarta maior indústria de cosméticos em faturamento do mundo, mas ocupa a terceira posição se for considerado o faturamento dos estratégicos subsegmentos de cosméticos e perfumaria (EUROSTAT, 2011). Dados da Agência EUROMONITOR indicam que a Natura concentra mais de $13 \%$ do mercado brasileiro, o que lhe dá a primeira posição no market-share do setor. Até o ano de 2004, a Unilever concentrava essa posição, mas tem perdido espaço para as demais indústrias e desde então a Natura assumiu a liderança no Brasil (Tabela 5).

De toda forma, a anglo-holandesa Unilever ainda tem expressiva participação no mercado brasileiro do setor em geral com quase $10 \%$ do total, sendo a principal indústria nas vendas de produtos de higiene pessoal, especialmente de desodorantes $(29,9 \%)$, produtos para banho $(23,6 \%)$ e cabelos (16,3\%). Já a Avon detém a terceira posição da participação nacional, 
com $9 \%$ do mercado e lidera as vendas de cosméticos-cores (maquiagem, esmalte, etc). (ABIHPEC, 2012).

Tabela 5 - Evolução do Market-Share da Indústria de Cosméticos no Brasil entre 2001 e 2009

\begin{tabular}{|l|c|c|c|c|c|c|c|c|c|}
\hline \multicolumn{1}{|c|}{ Empresas } & $\mathbf{2 0 0 1}$ & $\mathbf{2 0 0 2}$ & $\mathbf{2 0 0 3}$ & $\mathbf{2 0 0 4}$ & $\mathbf{2 0 0 5}$ & $\mathbf{2 0 0 6}$ & $\mathbf{2 0 0 7}$ & $\mathbf{2 0 0 8}$ & $\mathbf{2 0 0 9}$ \\
\hline Natura & $8.9 \%$ & $9.1 \%$ & $10.5 \%$ & $11.7 \%$ & $12.6 \%$ & $13.4 \%$ & $13.1 \%$ & $12.9 \%$ & $13.2 \%$ \\
\hline Unilever & $13.1 \%$ & $12.3 \%$ & $12.6 \%$ & $11.9 \%$ & $11.4 \%$ & $10.5 \%$ & $10.2 \%$ & $9.8 \%$ & $9.9 \%$ \\
\hline Avon & $8.1 \%$ & $8.3 \%$ & $7.9 \%$ & $8.3 \%$ & $8.2 \%$ & $8.6 \%$ & $9.0 \%$ & $9.2 \%$ & $9.5 \%$ \\
\hline $\begin{array}{l}\text { Procter \& } \\
\text { Gamble }\end{array}$ & $1.8 \%$ & $0.9 \%$ & $2.9 \%$ & $3.0 \%$ & $7.8 \%$ & $7.5 \%$ & $7.5 \%$ & $7.0 \%$ & $6.7 \%$ \\
\hline O Boticário & $5.9 \%$ & $6.6 \%$ & $6.3 \%$ & $5.9 \%$ & $6.0 \%$ & $5.5 \%$ & $5.9 \%$ & $6.2 \%$ & $6.3 \%$ \\
\hline $\begin{array}{l}\text { Colgate- } \\
\text { Palmolive }\end{array}$ & $8.9 \%$ & $7.6 \%$ & $7.3 \%$ & $7.2 \%$ & $6.6 \%$ & $6.3 \%$ & $6.1 \%$ & $6.0 \%$ & $6.1 \%$ \\
\hline $\begin{array}{l}\text { L'Óréal } \\
\text { Jonhson \& } \\
\text { Jonhson }\end{array}$ & $4.6 \%$ & $4.8 \%$ & $4.7 \%$ & $4.9 \%$ & $4.6 \%$ & $4.9 \%$ & $5.5 \%$ & $4.8 \%$ & $4.7 \%$ \\
\hline \begin{tabular}{l} 
Hypermarcas \\
\hline Nivea
\end{tabular} & - & - & - & - & - & - & $0.9 \%$ & $2.4 \%$ & $2.6 \%$ \\
\hline
\end{tabular}

Fonte: EUROMONITOR In. Barclays Capital, 2011.

O grupo Procter \& Gamble, que deu início as suas atividades no Brasil com a aquisição da Phebo, indústria tradicional instalada em Belém e pioneira na fabricação de sabonetes com extratos e essências da Amazônia (atualmente a Phebo integra outro grupo, a Granado Laboratórios), está na quarta posição do market-share do setor no Brasil com destaque para os produtos de cuidados masculinos, representando quase $39 \%$ nesse subsegmento no país.

Outra grande indústria brasileira, O Boticário, detém o 40ำ lugar no ranking mundial de faturamento do setor (WWD, 2009), participando com 6,3\% do mercado nacional e concentra a maior rede de franquias de perfumaria e 
cosméticos do mundo, com mais de novecentos franqueados, totalizando 2.382 unidades. O Boticário tem a segunda maior participação no subsegmento de perfumes, atrás apenas da Natura.

A Johnson \& Johnson concentra o maior mercado brasileiro de protetores solares com 32,8\% do total, e a Colgate-Palmolive participa com 6\% do mercado de consumo nacional, sobretudo no que diz respeito aos itens de higiene pessoal e cremes dentais. Além dos produtos com ingredientes convencionais, a Colgate introduziu em seu portfólio diversos produtos com princípios ativos da biodiversidade da Amazônia (Linha Amazônia), com matérias-primas do açaí, castanha, guaraná, murumuru e andiroba. Registre-se que desde 2007, a L'Oréal tem perdido mercado no país para outras indústrias do setor, entretanto, ainda possui significativa participação na venda de produtos denominados "premium", produtos capilares e cosméticos-cores.

Finalmente, dentre as lideres do mercado nacional, a Hypermarcas responde por $2,6 \%$ do market-share do setor e os produtos para cabelos, cuidado da pele e esmaltes representam os principais itens de vendas da empresa. Como o grupo adquiriu um diversificado portfólio de marcas ${ }^{8}$ que já existiam no mercado brasileiro, a empresa também tem tido destaque no cenário internacional, passando a integrar o ranking das cem indústrias de maior faturamento do mundo, alcançando o 58ํ lugar no último ano de análise (WWD, 2009).

Apesar do faturamento do setor de cosméticos e da participação no mercado no Brasil ser formado por essas grandes indústrias nacionais e

\footnotetext{
${ }^{8}$ A Hypermacas adquiriu a Aquamarine, Avanço, Bia Blanc, Bigfral, Bigmaxi, Biocolor, Biorene, Bozzano, Cenoura \& Bronze, Contouré, Denorex, Dermil, Eh!, Eve Sabonete Íntimo, Hydrogen, Italian Pine, Jontex, Juvena, Leite de Colônia, Lovetex, Lucretin, Luminance, Monange, Niasi, Novitá, NYLooks, Lolla, Pom Pom, Rastro, Risqué, Selsun, Très Marchand e Zene.
} 
transnacionais, de acordo com a entidade representativa das indústrias de cosméticos no país, um balanço geral revela que o grupo das pequenas e médias indústrias é predominante e essa condição está associada "à simplicidade da base técnica de importantes segmentos do setor, que se caracterizam pela manipulação de fórmulas relativamente simples. Nesse sentido, é comum encontrar casos de empresas de cosméticos que se desenvolveram a partir de um negócio de farmácia de manipulação", como aponta Garcia (2005: 159).

Desse modo, o setor industrial de capital nacional é caracterizado pela presença maciça de micro, pequenas e médias empresas, a maioria delas com base técnica mais simplificada, como também das indústrias mais estruturadas e com marcas mais consolidadas no mercado. O grupo mais conhecido no mercado das pequenas e médias indústrias é formado, entre outras, pela Ox Marrow, Laqua di Fiori, Niasi, Valmari, Contém 1g, Nazca, Valmari, Payot e Água de Cheiro.

\subsection{Normatização, Certificação e Legislação}

No Brasil, as normatizações e os licenciamentos do setor são realizados pela ANVISA (Agência Nacional de Vigilância Sanitária no Brasil) e para a exportação dos produtos de higiene pessoal, perfumes e cosméticos, a regularização é feita por diferentes órgãos internacionais, dentre eles, a Agência norte-americana FDA (Food and Drugs Administration) e a COLIPA (The European Cosmetic, Toiletry and Perfumery Association), que representa os países membros da União Europeia. 
Na busca de convergência do sistema de regulação brasileiro com os órgãos internacionais mais representativos, a ANVISA utiliza diversos critérios semelhantes, dentre eles, a nomenclatura do setor definida de acordo com a Resolução no 211, de 14 de julho de 2005 (As normas e procedimentos para obtenção de registros e notificações foram atualizados nessa nova resolução; Anexo 2). A legislação nacional sobre cosméticos é harmonizada com os países membros do Mercosul (Resolução no31 de 1995), e compatível com as legislações adotadas nos EUA e na União Europeia.

No que se refere à classificação de produtos da indústria de higiene pessoal perfumaria e cosméticos, a ANVISA determina dois níveis de risco para os usuários, sendo os produtos com risco nível 1 aqueles que possuem:

"propriedades básicas ou elementares, cuja comprovação não seja inicialmente necessária e não requeiram informações detalhadas quanto ao seu modo de usar e suas restrições de uso, por causa das características intrínsecas do produto. Constam nesse nível produtos, tais como: sabões, xampus, cremes de barbear, loções pós-barba, escovas dentais, fios dentais, pós, cremes de beleza, loções de beleza, óleos, make up, batom, lápis para os lábios e delineadores, produtos para os olhos e perfumes" (ANVISA, 2005).

Já os produtos com risco nível 2 apresentam:

"indicações específicas, cujas características exigem comprovação de segurança e/ou eficácia, bem como 
informações e cuidados, modo e restrições de uso. Nesse nível se encontram produtos que apresentam risco potencial, tais como: xampus anticaspa, cremes dentais anticárie e antiplaca, desodorantes íntimos femininos, desodorantes de axilas, esfoliante químicos para a pele, protetores para os lábios com proteção solar, certos produtos para a área dos olhos, filtros UV, loções bronzeadoras, tinturas para cabelos, descolorantes, clareadores, produtos para ondulação permanente, produtos para crescimento de cabelos, depiladores, removedores de cutícula, removedores químicos de manchas de nicotina, endurecedores de unhas e repelentes de insetos" (ANVISA, 2005).

Para efeitos de comparação, o FDA tem como uma das exigências principais, a listagem dos ingredientes por ordem decrescente de quantidade para posterior registro na embalagem do produto. Além disso, os cosméticos desenvolvidos com fins terapêuticos, como os xampus antiqueda, protetores solares e bronzeadores, pastas de dentes anticárie, desodorantes e antiperspirantes, recebem regulamentação mais rigorosa, como nos medicamentos.

As normas técnicas estabelecidas nos últimos anos pela ANVISA para as atividades industriais que utilizam a biodiversidade estão provocando impactos consideráveis, sobretudo no conjunto das indústrias que desenvolvem produtos com princípios ativos naturais, uma vez que eles apresentam graus diversos de periculosidade à saúde humana e necessitam de certificados biofísico-químico (ou de origem) que atestem a sua qualidade e, assim, o 
potencial desse segmento está diretamente associado ao atendimento das novas exigências de certificação e regulamentação dos produtos.

As rigorosas exigências expressas pelos órgãos reguladores, principalmente aquelas relacionadas aos padrões de qualidade de processos e produtos, têm provocado fortes impactos no mercado como um todo e ao longo de toda a sua cadeia produtiva. As exigências dos diversos testes químicos e toxicológicos para o registro dos produtos estabeleceram um novo patamar científico-tecnológico para as empresas do setor e esse processo alterou automaticamente os parâmetros de competição no mercado nacional, tornando-o evidentemente mais compatível com os que vigoram no exterior.

Nesse sentido, todas as empresas do setor devem ser registradas na ANVISA e somente após sua regularização são licenciadas, credenciadas e autorizadas para funcionamento e realização de suas atividades industriais. As exigências atingem as diversas etapas da cadeia produtiva de cosméticos, incluindo desde as empresas produtoras, como também as importadoras, empresas de transporte e distribuidoras, sendo assim submetidos à avaliação os processos de fabricação, purificação, armazenamento, fracionamento, distribuição, exportação, importação e embalagens dos insumos e produtos. A agência recebe por ano de 3 mil a 4 mil pedidos de registro de novos produtos e devido às atualizações das normas com a nova RDC nํ211, mais de 70 mil pedidos de notificações de produtos de grau de risco baixo foram registrados em 2006, por exemplo (ANVISA, 2007).

Dessa forma, a forte e crescente regulação internacional tem obrigado os produtores a se adequarem aos padrões de qualidade exigidos pelos mecanismos de certificação em vigor, sobretudo quando envolve exportação de produtos. A incorporação dessas variáveis tem sido imprescindível para 0 
desenvolvimento dos bioprodutos diferenciados e elas estão visivelmente destacadas nos processos produtivos adotados, principalmente, da grande indústria, que busca assegurar todas as etapas decisivas das atividades industriais, tais como a coleta, o processamento, os ensaios laboratoriais, o desenvolvimento dos produtos finais, o requerimento de registros e patentes dos processos e/ou produtos. Algumas indústrias nacionais já dispõem desses mecanismos de rastreabilidade da produção e de instrumentos que atestem a sustentabilidade e o manejo das matérias-primas, com destaque para a Natura, por exemplo. No entanto, a indústria de pequeno porte ainda não disponibiliza de recursos suficientes que lhes permitam certificar a origem dos produtos com os selos-verdes, apresentando normalmente somente as certificações dos órgãos reguladores, como da ANVISA. 


\section{CAPÍTULO 3 - OS CIRCUITOS DE INOVAÇÃO DOS COSMÉTICOS: desenvolvimento de novos produtos e processos industriais}

Como ponto de partida da abordagem teórica sobre os circuitos de produção e inovação dos cosméticos, optamos por iniciar a discussão a partir do uso dos recursos naturais e, especialmente da biodiversidade, no âmbito das recentes mudanças das relações contemporâneas entre a economia, a sociedade e o Estado. Elas indicam que a sua (re)valorização deve ser compreendida no contexto de tais relações e segundo um cenário de transformações científicas, tecnológicas, informacionais, econômicas, políticas, sociais, culturais, ambientais, paisagísticas e das forças produtivas mundiais que traçam novas dimensões entre a sociedade e o uso dos recursos naturais.

Essa nova valorização tem sido orientada principalmente pela revolução técnica-científica-informacional, associada às antigas e renovadas possibilidades e modalidades de uso dos objetos, meios e recursos (SANTOS, M., 2004a). Os complexos processos de descobertas científicas e de inovações tecnológicas imprimem novos arranjos e valores, ganham concretude e interagem de diferentes modos e em diversas escalas, que vão do global ao local. Tal revolução científico-tecnológica tem determinado um conjunto de sofisticados processos que moldam novos estilos de produção, comunicação, gestão, modos de vida e promove formas e graus diversos de transformação das sociedades, bem como, os usos que essas decidem dar ao seu potencial tecnológico (CASTELLS, M. 1999).

Nas últimas décadas do século XX, além das tecnologias da informação e comunicação, outros grandes avanços tecnológicos concentraram-se no 
desenvolvimento de "materiais avançados, fontes de energia, aplicações na medicina, técnicas de produção (já existentes ou em potenciais, tais como a nanotecnologia) e tecnologia de transportes, entre outros" (CASTELLS, M., 1999, p. 68). Desse ponto de vista, emerge uma questão acerca da importância do desenvolvimento tecnológico e do acesso às informações estratégicas associadas, por exemplo, aos recursos naturais, isto é, da importância do avanço da ciência e da tecnologia (C\&T) em diversos campos do conhecimento, sobretudo nas áreas mais nobres das hard sciences (biologia molecular, química fina, nanotecnologia e física nuclear, principalmente), que apresentam altíssima capacidade de transformar a riqueza natural em capital, com um novo e alto valor agregado.

Dentre o crescente avanço das pesquisas das hard sciences, aqui nos interessa destacar as áreas de biotecnologia e nanotecnologia aplicadas ao uso da biodiversidade, que tem permitido a manipulação e o controle mais sofisticados sobre o processo de produção, como também potencializando seus tradicionais usos e aplicações, cujos resultados têm favorecido os padrões de qualidade e inovação de produtos e processos nos vários steps produtivos, dentre eles, os que ocorrem atualmente nas indústrias de cosméticos.

\subsection{Tecnologias da vida: uso da informação genética e biológica}

Como se sabe, os núcleos mais ativos no desenvolvimento de C\&T avançada concentram-se ainda nos principais centros do poder mundial, sendo esses mais capazes de disputarem os novos ou renovados mercados do competitivo cenário global atual. São múltiplas as repercussões desse 
processo, que vão desde as transformações socioeconômicas, aí incluídas os processos produtivos, a organização e a divisão territorial do trabalho, os padrões de consumo, a cultura, a ética, como também, as mudanças geopolíticas e ambientais (SANTOS, M., 2004a; ALBAGLI, S., 1998a).

Peter Dicken (2010) aponta que "a tecnologia deve ser vista basicamente como um agente habilitador ou facilitador - viabilizando novas estruturas, novos arranjos organizacionais e geográficos das atividades econômicas, novos produtos e novos processos (...). Em um ambiente altamente competitivo, assim que determinada tecnologia é utilizada por uma empresa, sua adoção pelas demais pode se tornar praticamente imprescindível para garantir a sobrevivência competitiva" (DICKEN, P., 2010: 92).

Desse modo, a inovação torna-se fundamental para o crescimento das empresas e dependendo do setor econômico, os ciclos de produtos parecem estar cada vez mais curtos, forçando o lançamento constantemente de novos produtos e o desenvolvimento ou redefinição de novos processos de produção. Dicken (2010) indica três principais condições para o desenvolvimento tecnológico: i) o lançamento de um novo produto quando o atual se torna obsoleto, promovendo ciclos de 'sobreposição'; ii) o prolongamento do ciclo do produto já existente, efetuando pequenas modificações desse próprio produto, atualizando ou descobrindo novas aplicações; iii) a implementação de alterações na própria tecnologia do produto para torná-lo mais competitivo.

Contudo, também vale observar que nem todos os lugares e nem todos os empreendimentos se beneficiam do desenvolvimento tecnológico do mesmo modo, tendo em vista que num ambiente altamente competitivo ele também pode se tornar fonte de desigualdades. Assim como assinalou Milton Santos (1979; 2004): "As diferenças entre os países desenvolvidos e os 
subdesenvolvidos são gritantes. Como esses últimos se voltam cada vez mais para as exportações, 'as exigências da competição internacional acarretam uma demanda crescente de know-how (G. Jones, 1971, p. 20)'. A esse respeito, eles encontram enormes dificuldades. As transferências de tecnologia se chocam com os segredos comerciais ou a exclusividade do know-how, e também com os preços elevados das patentes" (idem, 2004, p. 120).

Da mesma forma, há que se destacar a desigual distribuição espacial das reservas de recursos naturais, que além do conhecimento técnicocientífico, provoca também acirrada disputa entre os detentores dessas riquezas e aqueles que não contam com tais reservas em seus territórios. Já sob esse aspecto, observamos que as maiores reservas de recursos e diversidade biológica existentes no planeta concentram-se basicamente nos países localizados nos trópicos, caracteristicamente menos desenvolvidos que os países do "Norte", dentre eles, destacam-se o Brasil, Colômbia, Peru, Equador, México, Indonésia, Malásia, Congo.

É nesse panorama que Jeremy Rifkin (1999) aponta que uma das principais disputas do século XXI envolverá o controle da biodiversidade e da informação genética ali contida, implicando desse modo em profundas divergências sobre o uso dos recursos, o acesso e o conhecimento que se tem sobre eles. A biotecnologia pode ser definida como "qualquer técnica que utilize organismos vivos (ou partes de organismos), com algum dos seguintes objetivos: produção ou modificação de produtos; aperfeiçoamento de plantas ou animais e descoberta de microrganismos para usos específicos (RAMALHO, Y., et al., 1990).

Embora o uso dessas técnicas seja milenar, por exemplo, com os processos de fermentação da uva e do trigo para a elaboração de vinho e pão, 
ou posteriormente com a revolução da microbiologia e a descoberta científica da estrutura da hélice dupla do $\mathrm{DNA}^{8}$ em 1953, foi apenas na década de 1970 que a base tecnológica da engenharia genética permitiu a transferência de material genético entre organismos vivos com a combinação e a recombinação do DNA (CASTELLS, M., 1999; ALBAGLI S., 1998a). Além dos tratamentos terapêuticos, a tecnologia do DNA recombinante possibilitou a sintetização de enzimas e receptores responsáveis ou associados a diversas doenças, facilitando o desenvolvimento de medicamentos e sendo assim considerada como "a pedra fundamental da biotecnologia moderna" (REIS, C et al., 2009).

Dentre os exemplos de processos e técnicas utilizadas nas áreas de biotecnologia (Figura 1), podemos citar a produção de fármacos, cosméticos, vacinas, antibióticos; o melhoramento genético para o cultivo de plantas; técnicas de fermentação industrial; controle biológico de pragas e doenças a partir de biofungicidas, entre outros (FERREIRA, M. E; FALEIRO, F. G., 2008).

Figura 1 - Exemplos de Processos Associados à Biotecnologia

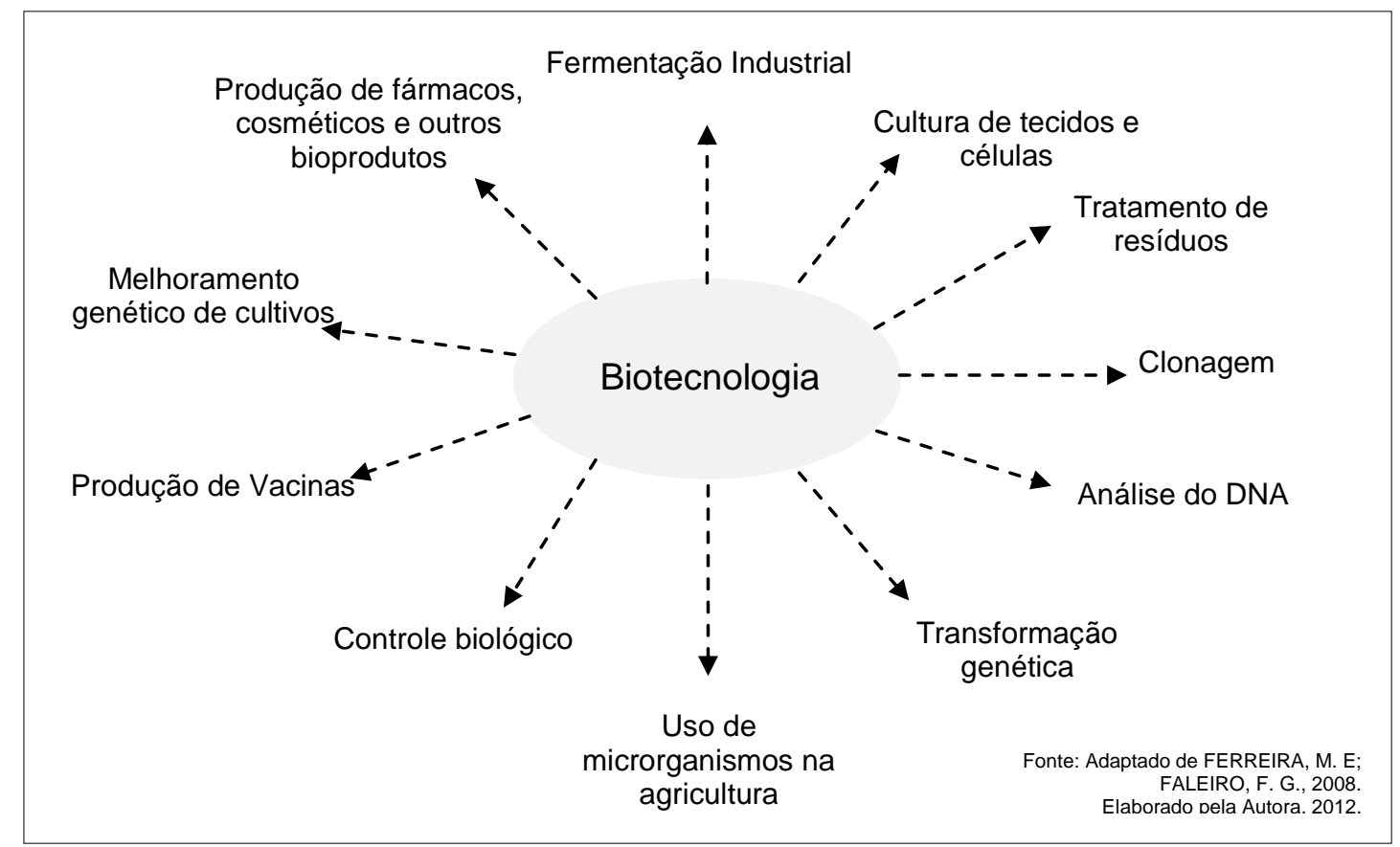

${ }^{8}$ DNA (deoxyribonucleic acid), composto orgânico responsável pela informação hereditária contida nos genes. Em português, ADN: ácido desoxirribonucléico 
A possibilidade de manipular e/ou alterar a informação genética dos organismos no desenvolvimento de processos e produtos foi se ampliando a partir de 1970, tendo na medicina o seu maior campo de atuação. O ingresso de empresas baseadas na aplicação intensiva e produção industrial de novos conhecimentos da biologia molecular, sobretudo nos EUA (norte da Califórnia, San Diego, Nova Inglaterra, Maryland, Virginia e Carolina do Norte), foram algumas das diversas empresas, no geral subsidiárias de grandes universidades e centros hospitalares de pesquisa, a usar as novas tecnologias. Todavia, dificuldades científicas e problemas técnicos aliados aos obstáculos legais nos anos 1980 retardaram a revolução biotecnológica e as empresas inovadoras em pesquisas genéticas foram absorvidas por grandes grupos farmacêuticos e químicos, como a Merck (EUA) e a Roche (Suíça) (CASTELLS, M., 1999). Desse modo, houve um deslocamento do centro dinâmico do setor que contava anteriormente com empresas emergentes especializadas em biotecnologias para os gigantes industriais interessados em ampliar seus mercados nas áreas de saúde humana, animal, recursos vegetais e da química (ALBAGLI S., 1998a).

Além desses campos, a agroindústria foi outro setor beneficiário das novas tecnologias, marcando um processo de modernização nos setores agrícolas voltados para as pesquisas relacionadas ao melhoramento genético de espécies, o desenvolvimento de novos cultivares e dos sistemas de cultivos complexos, como os agroflorestais. No Brasil, esse setor tem sido um dos mais destacados nas áreas das pesquisas biotecnológicas, sobretudo no que se refere ao desenvolvimento genético de alimentos, sobressaindo as cadeias produtivas dos grãos e da carne (COSTA, W. M, 2007; MIGUEL, L. M., 2007). 
É nesse contexto que o aproveitamento dos recursos genéticos e biológicos mediante as avançadas técnicas da biotecnologia atribui à biodiversidade valor estratégico no novo paradigma tecnológico, "cujo núcleo central consiste no desenvolvimento de uma capacidade cada vez maior de tratamento da informação, bem como de sua aplicação direta no processo produtivo: seja de informação simbólica, por meio da comunicação inteligente entre máquinas ou por máquinas, como na microeletrônica e na informática; seja ainda da informação da matéria viva, por intermédio da engenharia genética, base das biotecnologias avançadas" (ALBAGLI, S., 1998b, p. 7).

Nesse panorama, as revoluções das tecnologias da informação integram também a difusão das tecnologias da vida, possibilitando a transformação do recurso natural, aqui no caso a biodiversidade, em recurso informacional. Nesse contexto, a motivação determinante para o recente alarde em torno da questão da biodiversidade vem sendo a possibilidade, através do avanço da fronteira científico-tecnológica, de manipulação da vida ao nível genético, potencializando largamente seus usos e aplicações e ampliando o interesse de importantes segmentos econômicos e industriais na biodiversidade como capital natural de realização futura (ALBAGLI, S., 1998b, p. 8).

A interconexão das economias, redes financeiras e de informação produzem novas funções das fronteiras nacionais, sobre as quais os Estados influem - ou não - em diferentes níveis. Segundo Bertha Becker (2004), o acesso e o controle dessas redes passam a ser estratégicos na vantagem competitiva e no exercício do poder em todas as escalas geográficas. Entretanto, a mesma autora aponta que esses processos não significam: 
"a dissolução do espaço geográfico e do valor estratégico da riqueza in situ. A revalorização e valorização da natureza são condicionadas por novas tecnologias. É o caso, sobretudo da natureza como fonte de informação para a biotecnologia, apoiada na decodificação, leitura e instrumentalização da biodiversidade (...). Em outras palavras, a natureza é valorizada como capital de realização atual ou futura e como fonte de poder para a ciência contemporânea" (idem, p. 34 e 35).

As pesquisas sobre o aproveitamento da biodiversidade com base nos avanços recentes da biotecnologia são alguns dos mais importantes e estratégicos temas no conjunto das atividades de Pesquisa e Desenvolvimento (P\&D), especialmente em países megabiodiversos como o Brasil. Os principais desafios nessas áreas envolvem, em primeiro lugar, um esforço concentrado e contínuo dos pesquisadores em ampliar o inventário das espécies da flora, da fauna e da microbiota, especialmente das florestas tropicais que concentram um número infinito de espécies ainda não conhecidas (COSTA, W. M, 2002; MIGUEL, L. M., 2007).

Uma exceção ao uso dos produtos naturais nos segmentos industriais contemporâneos está relacionada às atividades de bioprospecção para a produção de fitofármacos. Isto porque as pesquisas necessárias para o desenvolvimento desses tipos de medicamento demandam complexos e custosos processos de P\&D e os diversos obstáculos burocráticos e indefinições normativas e regulatórias na área de bioprospecção, especialmente nos países considerados ricos em biodiversidade, têm 
desestimulado os setores empresariais a desenvolverem fármacos derivados de ativos naturais. Como resposta, as pesquisas nessa área têm centrado seu foco na produção de drogas sintéticas por reunirem condições e características mais adequadas para o desenvolvimento de produtos industriais (COSTA, W. M., 2009).

Apesar do mercado brasileiro de fármacos figurar entre os principais do mundo, sobretudo na produção de medicamentos sintéticos, esse setor industrial apresenta-se concentrado quase que exclusivamente nas atividades de produção de medicamentos e marketing, não sendo capaz de implantar um verdadeiro processo de pesquisa, desenvolvimento e inovação tecnológica nessa estratégica área. As atividades mais intensivas em C\&T relacionadas à saúde não incorporaram as atividades industriais ao longo de toda a cadeia produtiva de fármacos. De acordo com Filho e Capanema (2010), "a pesquisa e o desenvolvimento em saúde para prospecção e validação de novos alvos terapêuticos com base no entendimento dos mecanismos das patologias a nível molecular, o desenvolvimento e a produção de insumos farmacêuticos ativos para o "ataque" a esses alvos, seja pela rota da tradicional síntese química ou pela moderna biotecnologia, demandam competências raramente observadas nas empresas e instituições científico-tecnológicas nacionais", seria o que Coutinho (2010) identificou de "especialização regressiva" (idem, p. 308).

Dentre as áreas de P\&D de novos produtos e processos, as nanotecnologias têm se destacado em diferentes setores de ponta, sobretudo nas pesquisas de engenharia de materiais e nas áreas de ciências da vida, representando uma das principais referências em inovação dos países líderes em tecnologia. A nanociência e a nanotecnologia constituem, respectivamente, 
ao estudo e às aplicações/manipulações tecnológicas de objetos, substâncias, sistemas e dispositivos que tenham ao menos uma de suas partes físicas menor que, ou da ordem de, algumas dezenas de nanômetros (MELO, C. P; PIMENTA, M., 2004). As nanopartículas (do grego nano, que significa pequeno, pigmeu) são formadas por minúsculas partículas, cujas dimensões são traduzidas em nanômetros $\left(1 \mathrm{~nm}=10_{--} ; 1\right.$ nanômetro equivale a um bilionésimo de um metro). Para efeitos de comparação, um nanômetro é setenta mil vezes menor que o diâmetro de um fio de cabelo (ALVES, O. L., 2012).

Trata-se de uma plataforma tecnológica com aplicação em diversos ramos industriais, desenvolvendo diferentes produtos, processos e serviços tecnológicos, que vão desde tecidos antibacterianos, pneus, pinturas modernas para automotivos, alimentos farináceos, produtos de higiene pessoal, dentre outros. As discussões sobre os riscos dessas aplicações tecnológicas são mundiais, tendo em vista que os produtos nanotecnológicos se encontram globalizados e ainda não existem padrões de avaliações sobre os efeitos dos nanomateriais, impossibilitando a construção de uma plataforma sólida e eficaz para ser aplicada em todo o mundo (ALVES, O. L., 2012).

\subsection{Pesquisa e Desenvolvimento (P\&D) de Ingredientes Ativos}

Uma das principais batalhas da nova competitividade baseada em Ciência e Tecnologia (C\&T) para as indústrias de cosméticos está associada ao desenvolvimento de princípios ativos inovadores. Os mercados consumidores cada vez mais exigentes e a tendência de crescimento dos produtos naturais elaborados de forma sustentável, colocam para as indústrias do setor o grande desafio de implantar um sistema adequado de P,D\&I 
(Pesquisa, Desenvolvimento \& Inovação) e de internalizar processos tecnológicos e normativos capazes de comprovar os benefícios e 0 desempenho dos novos ingredientes ativos.

Apesar do vigor das atividades de P,D\&I no setor é preciso destacar que na área de produtos naturais os desafios são ainda muito maiores, considerando que as informações envolvidas tanto dos insumos quanto dos produtos acabados sobre os ativos naturais ainda encontram-se indefinidas ou em extensos processos de pesquisa quanto suas comprovações de eficácia, segurança, estabilidade sensorial e aparência dos novos ingredientes. Nesse especializado segmento, a seleção e a pesquisa de ingredientes, os processos de elaboração de formulações, o estabelecimento e a verificação das especificações tornam o caminho mais longo para o setor de um modo em geral e, especialmente, para as pequenas e médias indústrias que já desenvolvem tecnologias e processos de formulação de produtos tradicionais e consagrados no mercado de consumo.

Estudos do setor apontam que a proximidade do segmento cosmético com outros setores industriais promove um intercâmbio de conhecimento e tecnologias desenvolvidos em seus campos correlatos, como nas áreas de medicamentos, alimentos e até mesmo do setor têxtil. Desse modo, diversos ativos (sintéticos ou naturais) aplicados em produtos cosméticos podem ser inspirados e/ou adaptados de insumos desenvolvidos por outras indústrias. Esses processos, definidos como cross-technology (FERRO, A. P., 2010), demonstram como diferentes ingredientes tradicionalmente utilizados em determinados setores industriais também podem servir de base nas formulações dos cosméticos e produtos de higiene. Exemplos dessa transferência são apresentados no quadro a seguir. 


\section{Quadro 1 - Insumos e Processos Tecnológicos de Setores Industriais Correlatos aos Cosméticos}

\begin{tabular}{|l|l|}
\hline \multicolumn{1}{|c|}{ Setor Industrial } & \multicolumn{1}{|c|}{ Insumos e Processos Tecnológicos } \\
\hline Saúde e Farmacêutico & $\begin{array}{l}\text { Sistemas de liberação de ativos (nanotecnologia, filmes } \\
\text { moleculares); peptídeos sintéticos, biopolímeros, emplastros, } \\
\text { enzimas clareadoras de pele, técnicas de engenharia genética e } \\
\text { de obtenção de extratos vegetais. }\end{array}$ \\
\hline Alimentos & $\begin{array}{l}\text { Suplementos nutricionais, como vitaminas e antioxidantes; } \\
\text { aromas; corantes, extratos vegetais; técnicas de fermentação. }\end{array}$ \\
\hline $\begin{array}{l}\text { Químico } \\
\text { (têxtil e tintas) }\end{array}$ & $\begin{array}{l}\text { Polímeros, sistemas de liberação, híbridos químicos, } \\
\text { acoplamento molecular, química verde, química de colóides e de } \\
\text { superfícies, fenômenos de ótica. }\end{array}$ \\
\hline
\end{tabular}

Fonte: FERRO, A. P., 2010.

Os principais ingredientes ativos (tipo e origem) utilizados nos produtos de higiene pessoal, cosméticos e perfumaria são representados basicamente pelas vitaminas, derivados de vegetais, produtos biológicos, ingredientes marinhos, proteínas, peptídeos e enzimas (Figura 2).

Figura 2 - Tipo e Origem dos principais ingredientes ativos utilizados em cosméticos

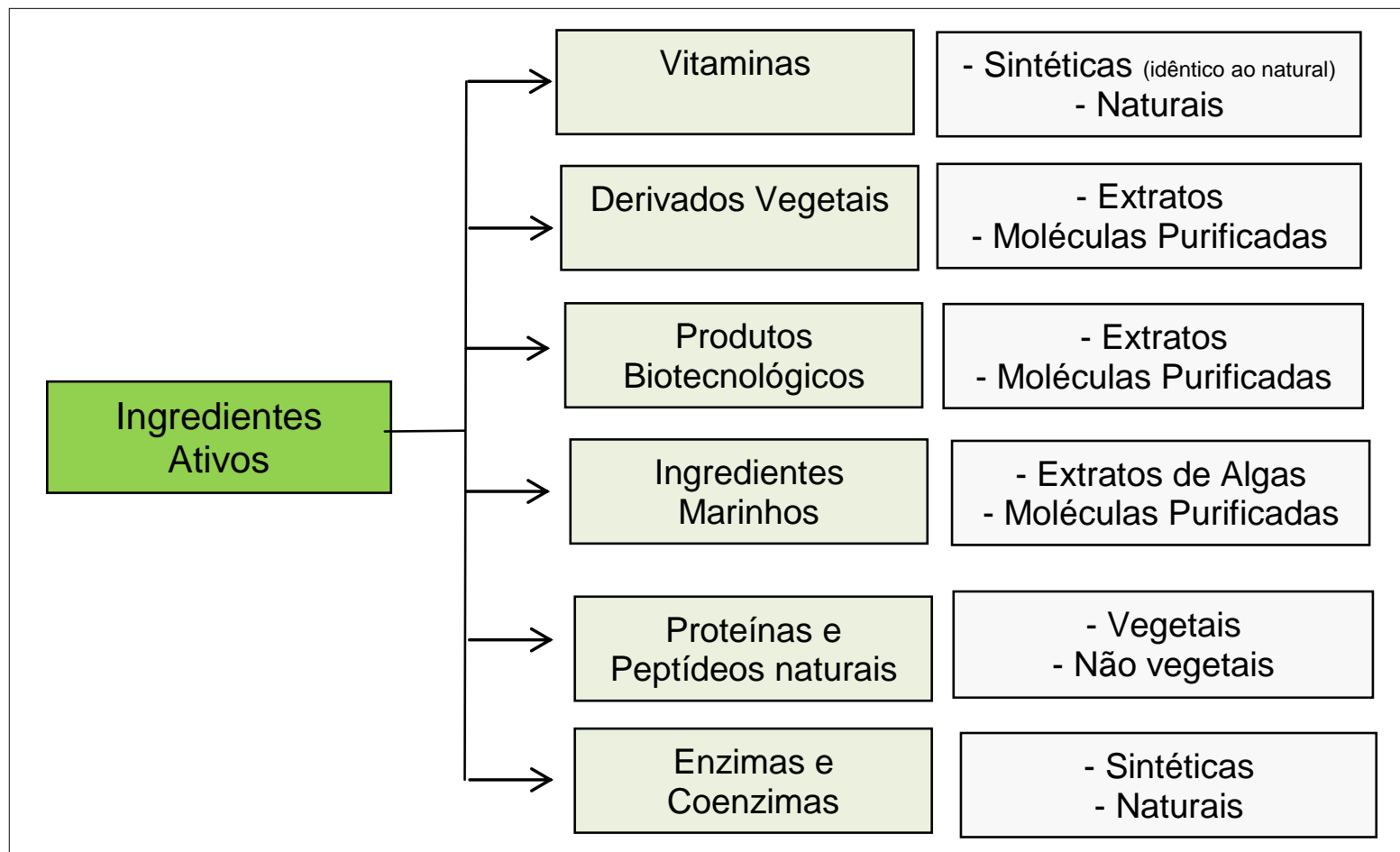


De modo geral, os ativos aplicados em cosméticos podem ser classificados da seguinte forma (Kline \& Company, 2001):

i. Vitaminas: constituem o grupo de ativos para tratamento da pele, sobretudo do rosto (Vitamina A: reguladora da queratização e da regeneração celular cutânea. Encontrada no fígado dos animais e nos vegetais; Pró vitamina B5: umectante e amaciante da pele; Vitamina B6: reguladora da secreção sebácea excessiva; Vitamina C: antioxidante, estimulador da produção de colágeno, possui atividade clareadora; Vitamina E: atua como agente antiradical livre na regeneração das camadas da pele. Encontrado no óleo de germe de trigo e outros óleos vegetais; Vitamina F: regenerador celular).

ii. Derivados Vegetais: formam o grupo dos extratos vegetais isolados ou associados e reúnem as outras diversas substâncias, como vegetais marinhos, proteínas e aminoácidos vegetais, extratos vegetais, etc.

iii. Produtos Biotecnológicos: a partir da microbiologia transforma ou trata de materiais de origem biológica; cultivo de células vegetais ou animais com a função de produção de determinado produtos. Exemplos de produtos biotecnológicos são as ceramidas e os ácidos hialurônico.

iv. Ingredientes Marinhos: ativos de origem marinha (algas verdes, vermelhas, entre outras) alternativos aos ativos animal, usados normalmente para a regeneração celular, restauração e hidratação. Permite o desenvolvimento de ácidos, elastina, colágeno, etc.

v. Proteínas e Peptídeos Naturais: excelentes agentes emulsionantes e de hidratação, bloqueadores dos efeitos dos radicais livres e reparadores da elasticidade da pele (colágenos, elastina, queratina, proteínas vegetais de amêndoa, trigo, soja, arroz e aveia, etc). 
vi. Enzimas e Co-enzimas: têm funções de melhorar ou corrigir as condições cutâneas.

Em um setor que é extremante competitivo, os esforços da competência científica, a capacidade de inovação tecnológica e das atividades de P\&D são alguns dos atributos indispensáveis, sobretudo para o desenvolvimento de produtos mais diferenciados, o que certamente as grandes empresas disponibilizam nesse disputado setor industrial. Dentre as maiores empresas de bens finais de cosméticos, a L'Oréal desponta em primeiro lugar do ranking de investimentos em P\&D (Tabela 6), representando 3,5\% do faturamento total e na $137^{\circ}$ posição das mil maiores empresas do mundo em 2010 , de acordo com estudo desenvolvido pelo departamento de negócios empresariais e inovação do Reino Unido (sigla em inglês, BIS, 2010). Além do desenvolvimento interno em P\&D, registre-se que as grandes indústrias contam com extensas redes de articulação com os principais laboratórios de pesquisas mundiais. Para efeitos de comparação, a Natura, líder brasileira do setor, investe em média $2,8 \%$ do seu faturamento em atividades de P\&D e inovação (Natura, 2011).

Tabela 6 - Ranking das Principais Indústrias de Cosméticos Investidoras em P\&D entre 2009 e 2010 (milhões de libras)

\begin{tabular}{c|c|c|c|c|c|c}
\hline Indústrias & $\begin{array}{c}\text { Invest. } \\
\text { (em } \mathbf{E m} \text { ) }\end{array}$ & $\begin{array}{c}\text { Crescim. } \\
\text { no último } \\
\text { ano (\%) }\end{array}$ & $\begin{array}{c}\text { Crescim. } \\
\text { médio nos } \\
\text { últimos 4 } \\
\text { anos (\%) }\end{array}$ & $\begin{array}{c}\text { \% em } \\
\text { relação } \\
\text { ao } \\
\text { faturam. }\end{array}$ & $\begin{array}{c}\text { \% em } \\
\text { relação ao } \\
\text { faturam. }\end{array}$ & $\begin{array}{c}\text { Investim. } \\
\text { + gastos } \\
\text { em relação ao } \\
\text { faturamento }\end{array}$ \\
\hline $\begin{array}{c}\text { L'Oreal } \\
\text { (França) }\end{array}$ & 541,27 & 5 & 12,0 & 26,5 & 3,5 & 6,4 \\
\hline $\begin{array}{c}\text { KAO } \\
\text { (Japão) }\end{array}$ & 306,82 & 2 & 9,0 & 46,9 & 3,6 & 6,2 \\
\hline $\begin{array}{c}\text { Givaudan } \\
\text { (Suiça) }\end{array}$ & 233,03 & -7 & 17,0 & 84,2 & 9,8 & 12,2 \\
\hline $\begin{array}{c}\text { Kimberly- } \\
\text { Clark }\end{array}$ & 186,39 & 1 & 1,0 & 10,7 & 1,6 & 6,0 \\
\hline \begin{tabular}{c} 
(EUA) \\
\hline
\end{tabular} & & & & & \\
\hline
\end{tabular}




\begin{tabular}{c|c|c|c|c|c|c}
\hline $\begin{array}{c}\text { Colgate- } \\
\text { Palmolive } \\
\text { (EUA) }\end{array}$ & 166,57 & 6 & 9,0 & 7,4 & 1,8 & 5,5 \\
\hline $\begin{array}{c}\text { International } \\
\text { Flavors \& } \\
\text { Fragrances } \\
\text { (EUA) }\end{array}$ & 120,03 & -9 & - & 57,3 & 8,3 & 11,2 \\
\hline $\begin{array}{c}\text { Shiseido } \\
\text { (Japão) }\end{array}$ & 101.39 & 5 & $-5,0$ & 39,6 & 2,2 & 4,5 \\
\hline $\begin{array}{c}\text { Lion } \\
\text { (Japão) }\end{array}$ & 60,25 & 6 & 8,0 & 85,0 & 2,8 & 5,4 \\
\hline $\begin{array}{c}\text { Estee } \\
\text { Lauder } \\
\text { (EUA) }\end{array}$ & 50,53 & 1 & 9,0 & 18,6 & 1,1 & 14,9 \\
\hline
\end{tabular}

Fonte: BIS, 2010.

As pesquisas do setor indicam que o subsegmento que mais investe em inovação e em P\&D está vinculado aos produtos de cuidados com a pele e, especialmente, aqueles de combate ao envelhecimento (ABIHPEC, 2012; ABC, 2011). Como apontado neste trabalho, o segmento de cuidado com a pele concentra os maiores faturamentos do setor em todo mundo e desse modo os ativos utilizados na formulação desses tipos de produtos têm se tornado alvo principal da indústria.

As pesquisas de ingredientes nessa área envolvem complexos testes laboratoriais e de P\&D na busca de avaliar os efeitos do uso dos ativos e das características próprias ou externas aos processos de envelhecimento (fatores naturais, raios solares, poluição, estresse, entre outros), e em sua maioria são realizados pelas grandes indústrias líderes do setor, os centros de referência e institutos de pesquisa avançada. Dentre as diversas tecnologias empregadas para a obtenção de ativos de ação antissinais, destacam-se as tecnologias recentes baseadas em hormônios obtidos via bioengenharia, células-tronco vegetais, reparação de DNA e substâncias minerais (FERRO, A. F. P., 2010).

No que se refere aos pedidos de patente de produtos derivados de ativos naturais, no caso dos cosméticos o cenário é um pouco distinto do que 
ocorre para os fármacos. Nos cosméticos, o ciclo de vida dos produtos é bem mais curto do que dos medicamentos, influenciando diretamente na requisição de patentes do setor. Especialistas do tema apontam que a maioria das patentes em cosméticos é relativa a nova forma de uso de um produto já existente e que os produtos de cuidado da pele têm sido o principal foco de patenteamento e propriedade intelectual da indústria de cosméticos. A França

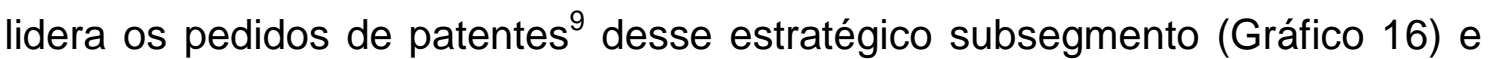
os grandes grupos industriais concentram majoritariamente a concessão desses registros de invenção, com destaque para a L'Oréal que deposita cerca de seiscentas patentes anualmente (TOUROUDE, M., 2009).

\section{Gráfico 16 - Distribuição de Patentes em Cosméticos de Cuidado da Pele por país de origem dos depositantes entre 2006 e 2010}

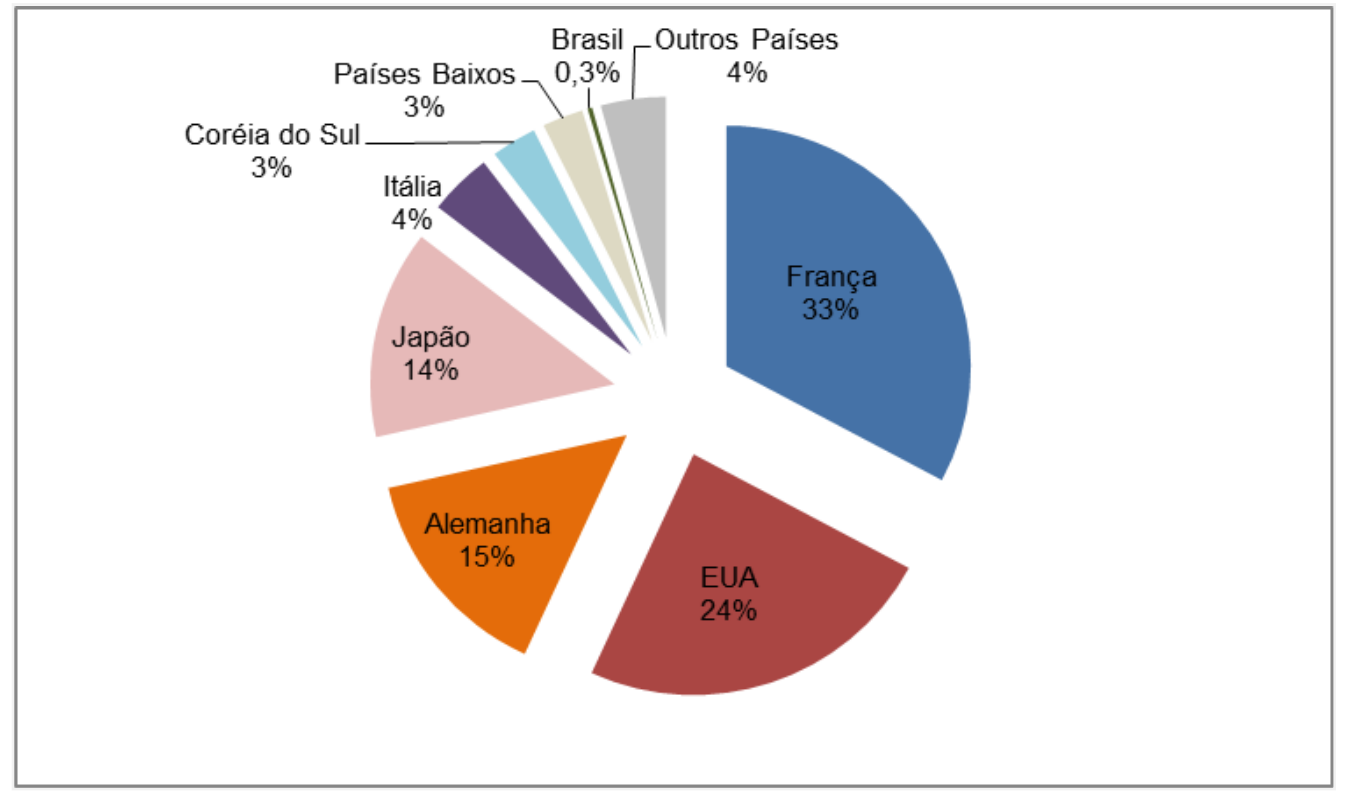

Fonte: USPTO, 2011. In: Souza, I. D. S. et al, 2011. Elaboração da Autora.

\footnotetext{
9 O levantamento inclui apenas as patentes de cosméticos voltados aos cuidados da pele depositadas, entre janeiro de 2006 e dezembro de 2010, nas bases do Uspto (United States Patent and Trademark Office), escritório norte-americano de referência no sistema internacional de propriedade intelectual. Além do mais, segundo a pesquisa, os setores industriais tendem a depositar as invenções com maior valor agregado nos EUA, tendo em vista o seu disputado mercado internacional (Souza, I. D. S. et al, 2011).
} 
De acordo com Souza et al. (2011), doze indústrias do setor de cosméticos concentram quase $50 \%$ do total de patentes concedidas durante 0 período analisado, são elas: L'Oréal, Avon, Kao, Coty, LVMH, P\&G, Unilever, Beiersdorf, Clariant, Cognis, Basf e Shin-Etsu (SOUZA, I. D. et al., 2011). Registre-se que o Brasil possui apenas $0,3 \%$ do total de patentes concedidas para produtos de pele, demonstrando a dificuldade do setor industrial brasileiro de se inserir no mercado global com mais competitividade frente as demais indústrias transnacionais.

A distribuição de patentes por campo tecnológico indica que os pedidos concedidos entre 2006 e 2010 se concentram em ativos sintéticos e semisintéticos, embora os ativos naturais representem importante dado dessas inovações. De todo modo, os produtos com ativos, sejam de origem natural ou não, figuram entre os produtos com maior número de patentes se comparado aos excipientes (derivados de silicone, ácido acrílico, polissacarídeos e outros excipientes naturais e não-naturais) e demais campos tecnológicos, como das nanotecnologias (Gráfico 17).

\section{Gráfico 17 - Distribuição de Patentes em Produtos para a Pele por campo tecnológico entre 2006 e 2010}

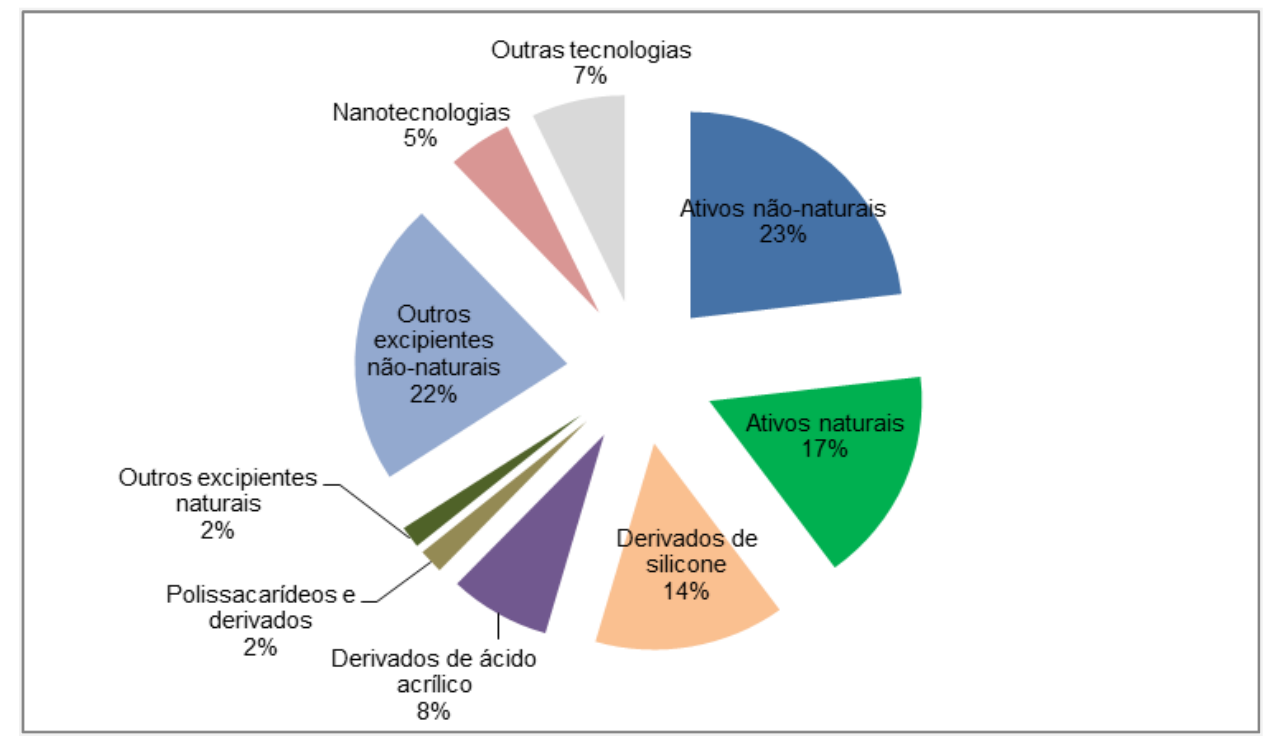


A Coty e LVMH destacam-se entre as indústrias do setor que mais adquiriram patentes em ativos naturais, contabilizando $50 \%$ do total concedido para cada uma delas. Apesar desse quadro, destaque-se que as nanotecnologias têm apresentado significativo crescimento na concessão de patentes. Os dados apontam que esses campos tecnológicos obtiveram crescimento de $400 \%$ entre 2009 e 2010 (Souza, I. D. S. et al, 2011).

\subsection{Matérias-Primas e Insumos: dos tradicionais aos inovadores}

Segundo Capanema et al. (2007), cerca de doze mil ingredientes em geral são utilizados na elaboração de produtos cosméticos. A padronização desses materiais é feita a partir de um sistema de codificação dos ingredientes, - International Nomenclature of Cosmetic Ingredient (INCI), que se baseia em nomenclaturas de acordo com listas internacionais utilizadas por cientistas e pesquisadores de todo mundo. Dessa forma, a composição dos diversos ingredientes é rotulada nas embalagens com uma identificação universal sem "distinção de idioma, caracteres ou alfabeto" (idem, p.150).

Dentre as matérias-primas com maior potencialidade econômica para o desenvolvimento de produtos nas indústrias de cosméticos, destacam-se os diferentes tipos e frações de plantas medicinais e extratos vegetais, corantes naturais, frutas, óleos vegetais, óleos essenciais e resinas.

As plantas medicinais possuem em sua composição princípios ativos utilizados em diversos tratamentos, servindo de base, principalmente, para os medicamentos fitoterápicos, mas também podem ser aplicados na elaboração de novos produtos cosméticos. Como todo medicamento, devem ter garantia 
de qualidade, efeitos terapêuticos comprovados, composição padronizada e segurança de uso para o consumidor.

Quanto aos corantes naturais, as recentes restrições e exigências sobre o uso de insumos artificiais em alguns setores industriais têm impulsionado o aumento da demanda por esses tipos de ingredientes (FDA, 2009). Além do desenvolvimento de novos aromatizantes, em especial, para a indústria de alimentos e novos pigmentos para a indústria têxtil, o setor de cosméticos também tem os corantes como material extremamente interessante para a produção de diversos itens e produtos, sobretudo em maquiagens.

As frutas também compõem a base para a formulação de cosméticos e têm sido utilizadas em diversos produtos, especialmente em cremes, xampus e condicionadores. Os diversos princípios ativos presentes nas cascas, folhas e polpas das espécies frutíferas indicam grande potencial de aproveitamento industrial, principalmente os exemplares de origem tropical.

Os óleos vegetais ou fixos são compostos basicamente por triglicerídios, extraídos normalmente por prensagem mecânica e apresentam difícil evaporação. Esses materiais têm seu uso difundido na indústria de cosméticos como ingredientes de bases, emolientes e hidratantes.

Dentre todos os produtos, um dos principais materiais de base natural para a produção de cosméticos diz respeito aos óleos essenciais. O uso de extratos e óleos essenciais neste subsetor e, em particular no ramo de perfumes, é muito antigo. No final do século XIX, com o desenvolvimento da química orgânica, descobriu-se a composição química dos óleos e dos extratos naturais e, como resultado dessas pesquisas, as indústrias de fragrâncias ampliaram significativamente sua utilização nos produtos (PALMA, 2000). 
Os princípios ativos dos óleos são obtidos basicamente através das técnicas de arraste a vapor, destilação e prensagem de sementes, frutos, flores, cascas e folhas. Por apresentarem características bioquímicas mais concentradas servem de matéria-prima para a composição de perfumes, mas as demais aplicações desses tipos de espécies oleaginosas também são encontradas nos segmentos industriais de alimentos, aromatizantes, bebidas, química e farmacêutica.

Em sua forma bruta ou processada, os óleos essenciais possuem componentes bioquímicos que são usados industrialmente como fixadores, fragrâncias, aromas e condimentos. Os materiais derivados da laranja, limão, hortelã, eucalipto, lima, citronela, lavanda e lavandin constituem as principais bases para formulação de óleos essenciais utilizados em diferentes segmentos. $\mathrm{Na}$ escala mundial de produção de óleos essenciais, cerca de vinte óleos representam quase $75 \%$ do total produzido (SHRINIVAS, P., 2009). Por outro lado, são registradas no mundo mais de trezentas substâncias de aplicação industrial e mesmo que não representem grandes volumes de produção, envolvem importantes trocas comerciais. O Quadro 2 a seguir ilustra os principais países produtores de óleos no mundo, entretanto, ressalte-se que esses dados não representam a quantidade total de essências utilizadas exclusivamente na indústria de cosméticos. 
Quadro 2 - Principais Óleos Essenciais Produzidos no Mundo (estimativas anuais)

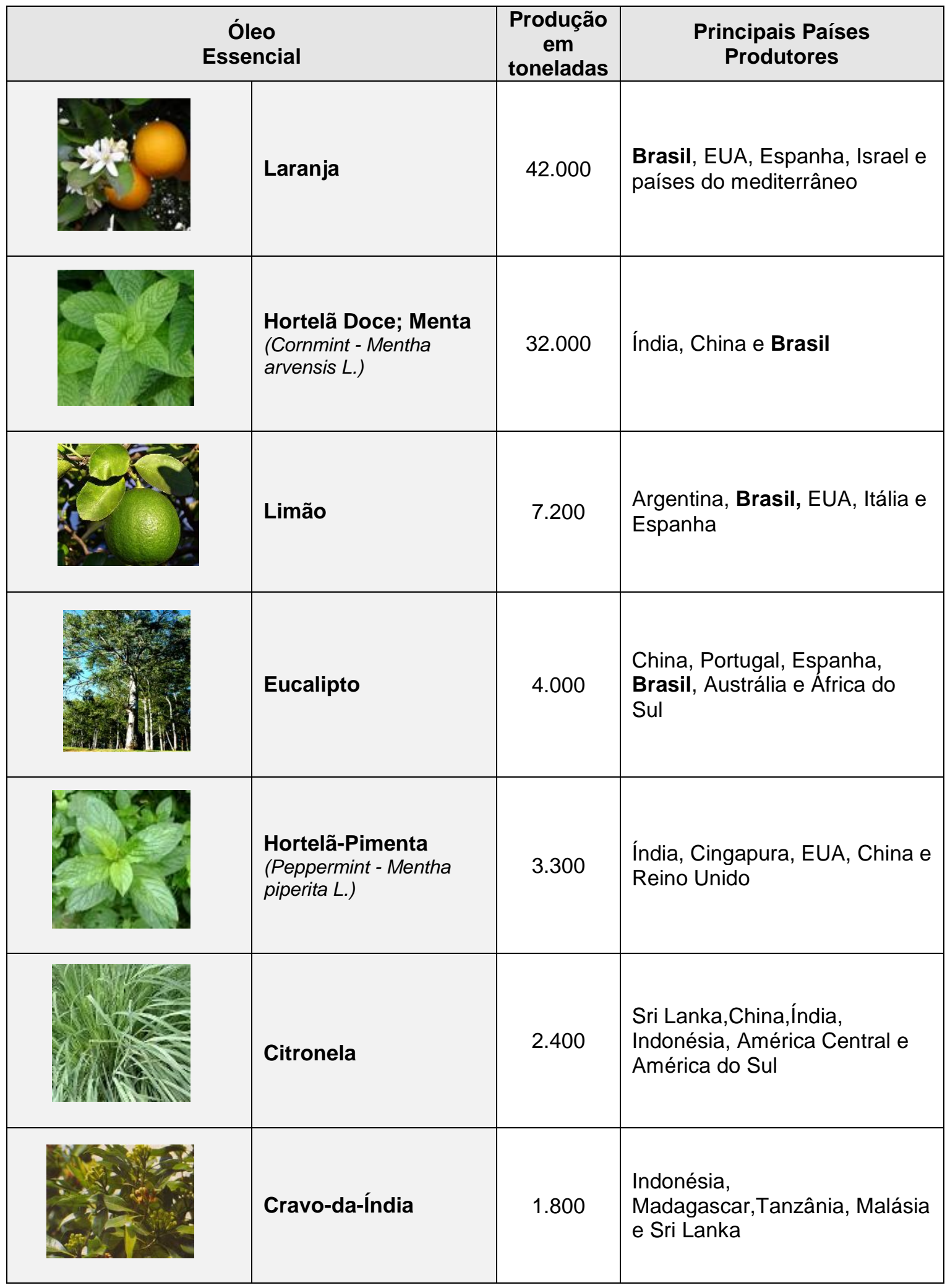




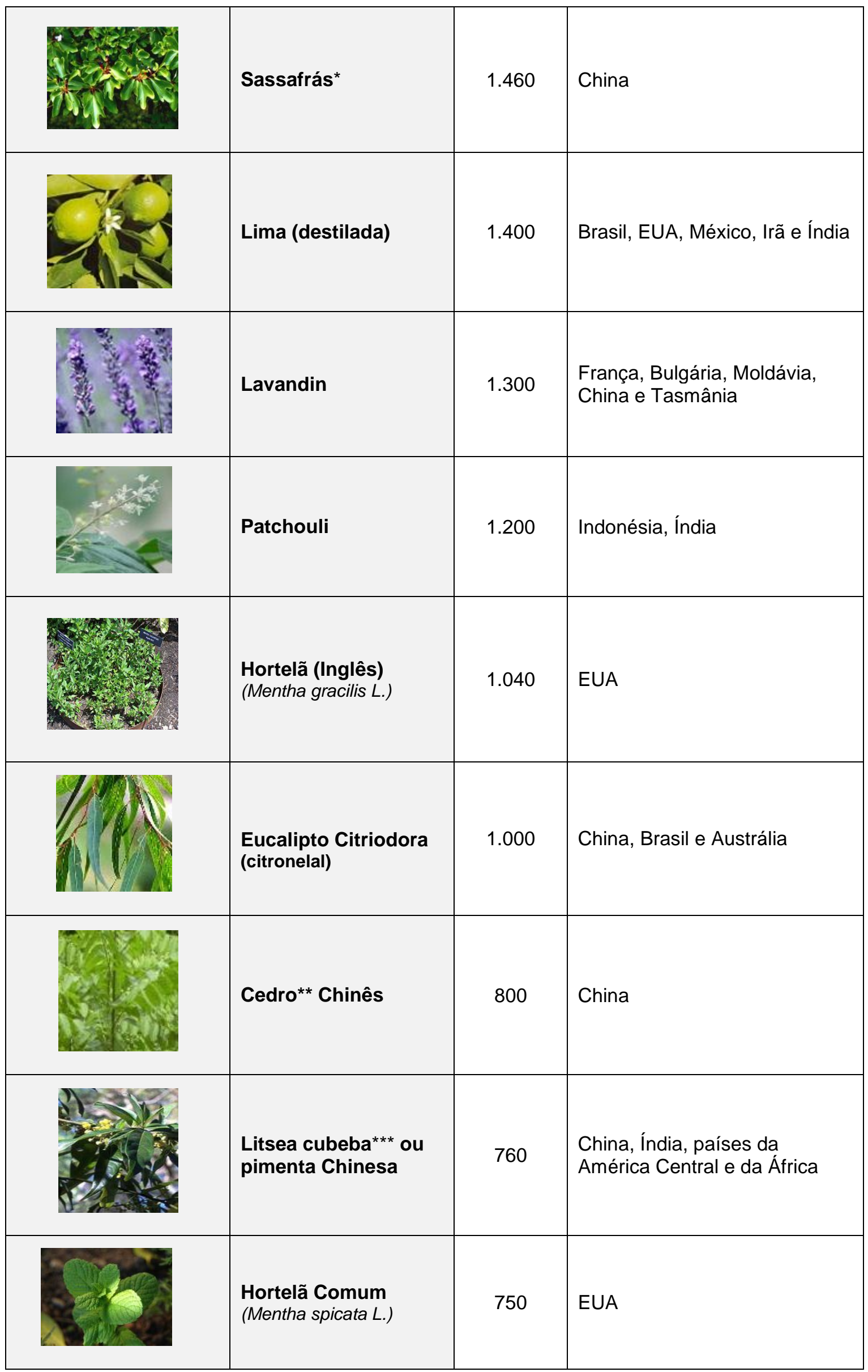




\begin{tabular}{|l|l|l|l|}
\hline & & \\
\hline & Cedro do Texas & 550 & EUA \\
\hline & Star Anis & 500 & China e Vietnã \\
\hline & & & \\
\hline & Mandarina & 460 & $\begin{array}{l}\text { Itália, Espanha, Brasil, } \\
\text { Argentina e EUA }\end{array}$ \\
\hline
\end{tabular}

Adaptação da Autora. Produção estimada em 2008. Fotos disponíveis na Quinari, empresa especializada em óleos essenciais (www.quinari.com.br). Fonte: SISTE - Italian Association of Herbalist Sciences and Technology, 2008; SHRINIVAS, P., 2009.*: O óleo de Sassafrás é extraído da madeira de uma árvore com o mesmo nome e utilizado na fabricação de fixador de perfumes e inseticidas. **: Produção de óleo de cedro no México e em outros países da América Central. ${ }^{* \star *}$ : A Litsea cubeba é conhecida por May Chang ou pimenta chinesa. O óleo possui alta concentração de citral, sendo utilizado em sabonetes, spray de ambiente, óleos de massagem, perfumes e desodorantes.

Além das matérias-primas tradicionais, destacam-se os insumos inovadores e as espécies 'exóticas' de interesse comercial para a aplicação em produtos cosméticos mais sofisticados, normalmente utilizados em cremes, loções, xampus e condicionadores com ingredientes exclusivos da flora tropical (Anexo 5). Em relação a esses tipos de produtos, o Brasil se enquadra entre os principais países detentores de matérias-primas diferenciadas, especialmente por sua rica biodiversidade e o foco vai para os produtos da Amazônia. Apesar do conhecimento e do uso das espécies vegetais da região para diferentes fins constituírem uma prática antiga por parte das suas populações tradicionais, só recentemente surgiram projetos e alguns empreendimentos pioneiros que têm sido capazes de combinar um esforço de pesquisa científica com as suas diversas possibilidades de aplicações para o aproveitamento industrial de uma série de produtos (MIGUEL, L., 2007). 
Os estudos especializados sobre os principais aspectos relacionados às características biológicas, bioquímicas e fito-químicas das espécies são realizados, sobretudo pelos centros e instituições de pesquisa e universidades, que têm um papel ativo nas pesquisas básicas e aplicadas sobre as possibilidades de aproveitamento econômico da flora regional. Os óleos vegetais e essenciais, frutas, extratos e variados tipos de pigmentos compõe 0 grupo das matérias-primas com maior destaque na produção de cosméticos. Dentre as espécies com participação mais expressiva, sobressaem a andiroba, a copaíba, o cupuaçu, o açaí, a castanha, o guaraná, o jaborandi, o murumuru, etc (Quadro 3).

\section{Quadro 3 - Principais Espécies da Amazônia utilizadas em Cosméticos}

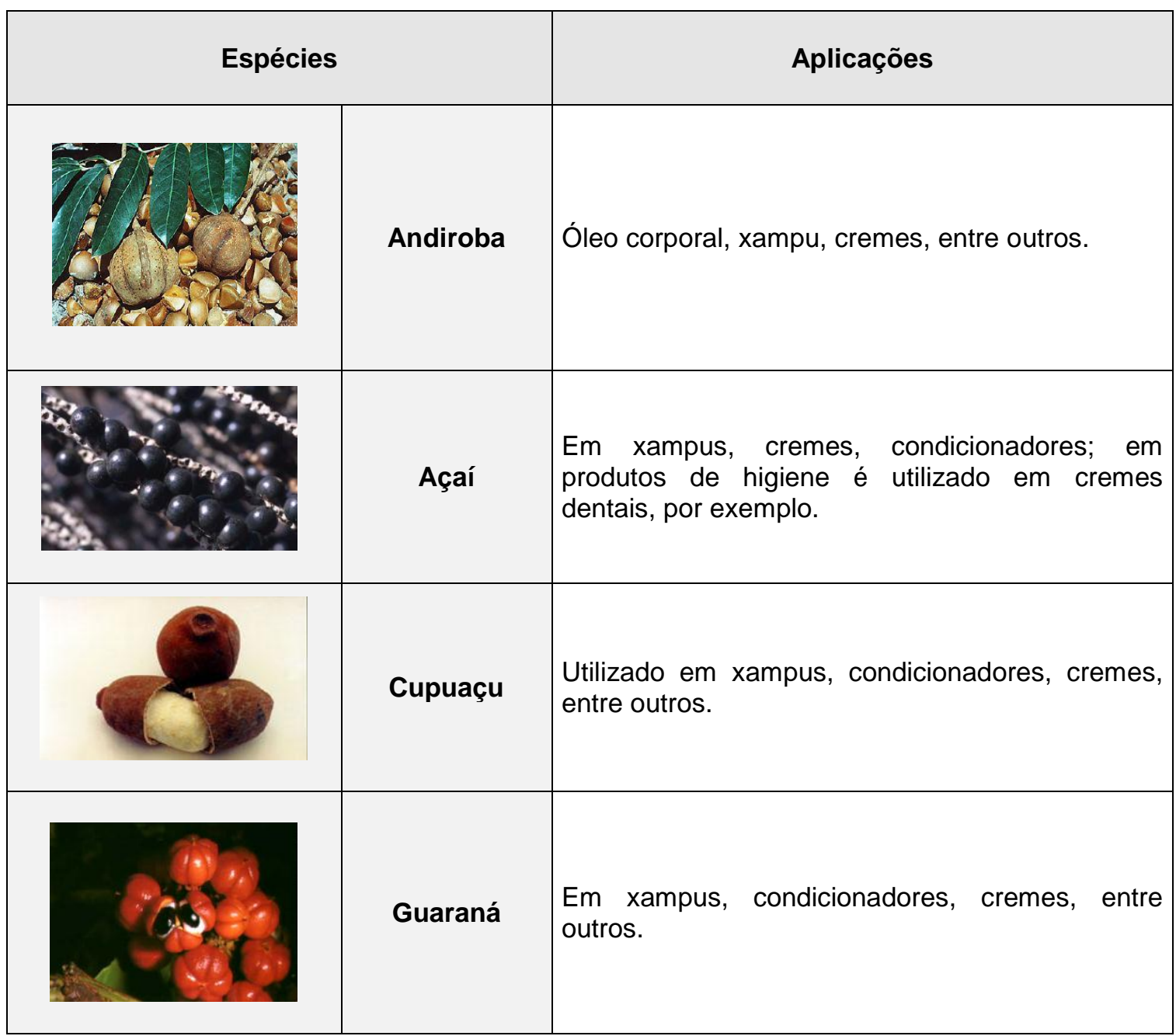




\begin{tabular}{|c|c|c|}
\hline Ale & Urucum & $\begin{array}{l}\text { Utilizado na produção de bronzeadores, óleos, } \\
\text { esmalte, batons, pó facial, etc; na indústria } \\
\text { farmacêutica é aplicado em cremes hidratantes, } \\
\text { pomadas cicatrizantes, no tratamento de hepatite, } \\
\text { infecções da pele, expectorante, anti-séptico } \\
\text { vaginal, para o tratamento da asma, de dores } \\
\text { renais, da hipertensão, conjutivite, amigdalite, } \\
\text { entre outros. }\end{array}$ \\
\hline & Jaborandi & $\begin{array}{l}\text { Em cremes e tônico capilar em xampus e } \\
\text { condicionadores. }\end{array}$ \\
\hline & Murumuru & $\begin{array}{l}\text { Extração de óleos para a fabricação de sabonetes } \\
\text { e cremes. }\end{array}$ \\
\hline 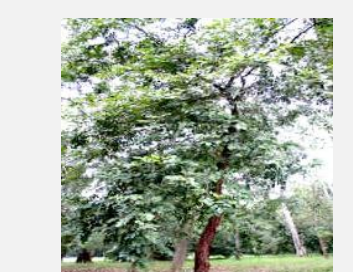 & Copaíba & $\begin{array}{l}\text { O óleo é utilizado como fixador de perfumes, em } \\
\text { cremes, sabonetes, xampus e auxilia no } \\
\text { tratamento da caspa e acne. }\end{array}$ \\
\hline $7+5$ & Pau-Rosa & $\begin{array}{l}\text { O óleo é utilizado como fixador de perfumes, em } \\
\text { colônias, cremes, pasta dental, entre outros. }\end{array}$ \\
\hline & Cipó-d'alho & Fixador de perfumes. \\
\hline & Sacaca & Fixador de perfumes. \\
\hline & Babaçu & $\begin{array}{l}\text { Utilizado na produção de sabonetes, sabão, } \\
\text { cremes, etc. }\end{array}$ \\
\hline
\end{tabular}




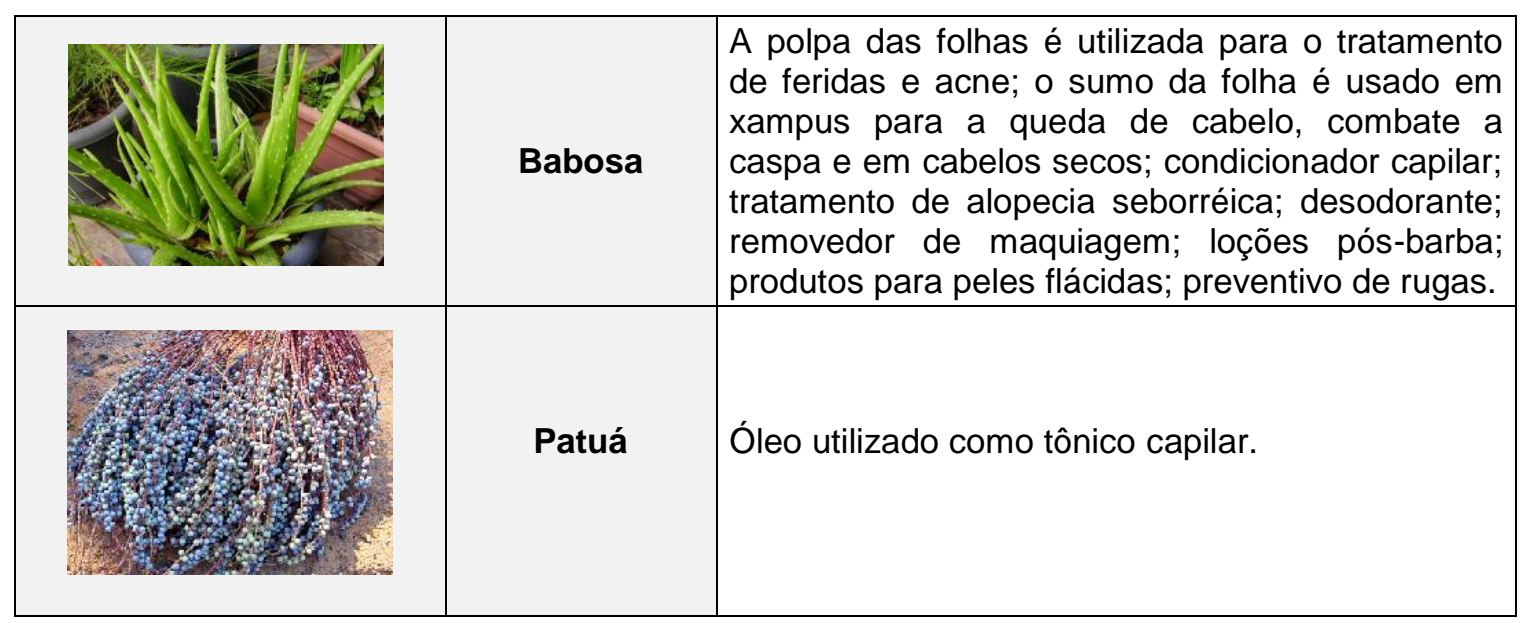

Fonte: Adaptado pela Autora de MAIA, J.G., ZOGHBI, M.G., ANDRADE, E.H. A. Plantas Aromáticas na Amazônia e seus Óleos Essenciais. Belém: MPEG, 2000. REVILLA, J. Plantas da Amazônia: oportunidades econômicas e sustentáveis. SEBRAE/AM, 2001. (Fotos retiradas do sítio da EMBRAPA).

Nesse cenário de crescente demanda por produtos de origem natural, novas oportunidades econômicas têm surgido em todo o mundo para o segmento de cosméticos e, principalmente, para os países ricos em biodiversidade, como o Brasil. Além disso, a Amazônia ganha destaque especial nessa promissora área, merecendo atenção a notável força dos produtos dessa região na opinião pública, sobretudo a internacional, e especialmente quando os produtos estão associados ao uso sustentável dos recursos naturais e da biodiversidade, contando ainda com a participação de comunidades tradicionais nos processos produtivos.

A trajetória a ser seguida pelo setor no que se refere ao desenvolvimento de produtos naturais e/ou orgânicos e dos processos normativos demonstra ser um caminho longo para essa indústria, sobretudo para as pequenas e médias empresas do setor que não contam com dispositivos semelhantes das grandes indústrias líderes (internacionais e nacionais). 


\subsection{Tendências de P\&D em cosméticos: nanocosméticos, cosmecêuticos, nutracêuticos e nutracosméticos}

As pesquisas em nanotecnologia, principalmente no desenvolvimento de produtos para o cuidado da pele, como agentes antissinais e de fotoproteção, têm sido um dos caminhos seguidos pelo setor. Os cosméticos com tecnologia de nanopartículas permitem maior eficácia nos tratamentos da pele, uma vez que as estruturas desses tipos de moléculas são menores e conseguem penetrar profundamente na epiderme e preencher de forma mais eficaz sulcos e rugas, por exemplo. Os nanocosméticos ${ }^{10}$ (Figura 3) são basicamente formulações que conduzem ativos ou outros ingredientes nanoestruturados com diâmetro menor que $1.000 \mathrm{~nm}$ e atuam de forma controlada nas camadas mais profundas da pele, podendo ser mais efetivos do que os produtos convencionais (STROHER, A. et al., 2010).

\section{Figura 3 - Nanocosméticos}

\section{Por dentro da nanopartícula}

Uma capa de gordura recobre o

princípio ativo do cosmético

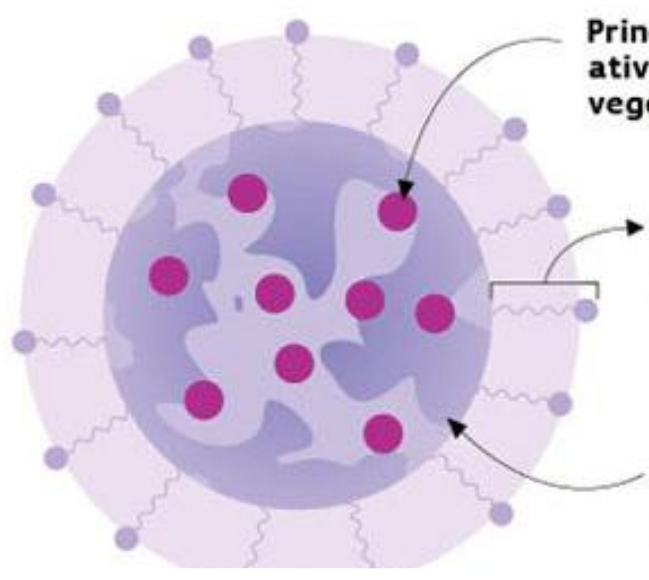

Fonte: Pesquisa Fapesp, 2011.
USAM

NANOTECNOLOGIA

Nanopartícula é uma estrutura

formada por um conjunto de moléculas com pelo menos uma de suas dimensōes (largura, profundidade ou altura) medindo entre 1 e 100 nanômetros. Um nanômetro equivale a um milímetro dividido por 1 milhão. A propriedade que diferencia a nanopartícula de materiais em escala macroscópica é o fato de ela ter uma área superficial muito maior que seu volume.

\footnotetext{
${ }^{10} \mathrm{Um}$ cosmético pode ser classificado como nanocosmético se conter estruturas organizadas e menores que 999 nanômetros - 1 nanômetro equivale a 1 milímetro dividido por 1 milhão de vezes (PESQUISA FAPESP, 2008).
} 
A introdução dos nanocosméticos no mercado internacional ocorreu com o lançamento de um creme anti-idade para o rosto baseado em nanopartículas de vitamina E pela Lancôme (marca de divisão de luxo da empresa L'Oréal) em 1993. As pesquisas foram desenvolvidas em parceria com a Universidade de Paris 11, que patenteou a inovação e a empresa a licenciou. Na década de 1990, as pesquisas em nanotecnologias apresentaram elevado crescimento e na busca por novas alternativas de formulações de produtos cosméticos, diversas empresas, sobretudo os grandes players mundiais do setor, passaram a investir no setor tecnológico dos sistemas nanoestruturados (lipossomas, nanoemulsões, nanopartículas lipídicas e poliméricas).

Dentre os produtos que mais contêm as nanopartículas, destacam-se as maquiagens (bases e pó faciais, batons, sombras, esmaltes e blushes), produtos para cabelos (xampus e condicionadores), filtros solares, cremes com agentes antirrugas (produtos para a área dos olhos), produtos anticelulite, cremes dentais, sabonetes, desodorantes e loções pós-barba (STROHER, A. et al., 2010).

Dados recentes demonstram que o mercado para nanocosméticos está em plena expansão, devendo crescer em média $16 \%$ ao ano e atingir mais de US\$ 150 milhões em 2012. De acordo com Pitman (2010), atualmente mais de mil produtos cosméticos possuem nanomateriais como ativo principal. No Brasil, as pesquisas em nanocosméticos são recentes e envolvem em sua maioria parcerias entre universidades e empresas do setor, embora as áreas acadêmicas concentrem atualmente essas atividades no país. Em 2005, o MCT criou a Rede de Nanocosméticos, integrando algumas das áreas prioritárias em inovação com a política industrial e tecnológica do Brasil, isto é, a de nanociência e nanotecnologia. A Rede de Nanocosméticos agrupa 
pesquisadores de centros de pesquisa e universidades do país, contando também com colaborações internacionais. Os parceiros nacionais reúnem pesquisadores da Universidade de São Paulo (USP), campus de São Paulo e de Ribeirão Preto, o Instituto de Pesquisas Tecnológicas (IPT), a Universidade Federal do Rio Grande do Sul (UFRGS), a Universidade Estadual de Campinas (Unicamp) e a Universidade Federal do Rio de Janeiro (UFRJ). Dentre os parceiros estrangeiros destacam-se aqueles associados a universidades da França, Alemanha, Inglaterra, Suíça, Suécia e Holanda (MCT, 2012; FAPESP, 2008).

Diversas pesquisas nessa área têm sido realizadas tanto pelas grandes indústrias do setor (Natura e $\mathrm{O}$ Boticário) como por pequenas empresas nacionais apoiadas, sobretudo, nas atividades em P\&D de universidades e centros de pesquisa. Como exemplos representativos da inovação no uso de ativos vegetais e da articulação entre esses agentes no Brasil, citamos a parceria entre uma pequena empresa de Porto Alegre, a Inventiva, com o Instituto de Química da UFRGS na pesquisa e industrialização de diversos cosméticos nanoencapsulados (extratos vegetais, óleos e vitaminas) para 0 tratamento da pele, cabelos e unhas.

Outro exemplo emblemático envolve os trabalhos entre o Departamento de Farmacologia, do Instituto de Biociências da UNESP, campus de Botucatu, com a empresa Chemyunion, de Sorocaba, no desenvolvimento de um creme antissinal a partir do extrato de uma planta conhecida como pico-picão (Bidens pilosa) que atua de modo semelhante ao retinol, responsável pela regeneração celular e síntese de colágeno. Além dessa pesquisa, a parceria entre a UNESP e a Chemyonion, apoiada por agências de fomento (Fapesp e Finep), resultou em um produto inovador a base da casca dos galhos de uma árvore da mata 
atlântica, o angico-branco (Piptadenia colubrina), e que está sendo comercializado industrialmente nos EUA, Colômbia, Argentina e Rússia e para várias empresas do setor (Natura, Estée Lauder, Avon, Johnson \&Johnson e Victoria's Secrets (UNESP Ciência, 2010; FAPESP, 2011).

Por outro lado, apesar das perspectivas promissoras e grandes avanços com o novo campo dos nanocosméticos, diversos pesquisadores apontam para os eventuais riscos e incertezas do uso dos nanomateriais sobre o meio ambiente e/ou a saúde humana. Como qualquer área tecnológica que utiliza novos materiais, a nanotecnologia envolve riscos sanitários, ambientais e de segurança alimentar, necessitando o desenvolvimento de pesquisas mais profundas quanto à sua segurança, aplicabilidade e ação das nanopartículas nos diferentes setores industriais. Segundo Pitman (2010), a pressão dos consumidores norte-americanos para a fiscalização mais severa dos produtos de higiene e cosméticos com nanomateriais forçou o FDA a financiar diversas pesquisas e regular o uso desse campo tecnológico, embora ainda o país não tenha um arcabouço legal.

No Brasil, grupos de pesquisa também têm se empenhado em criar protocolos confiáveis para uma avaliação correta dos diferentes benefícios, efeitos adversos, do ciclo de vida das nanopartículas, os rejeitos, dentre outros. Os parâmetros de avalição dos riscos são baseados principalmente na toxicologia, no entanto, eles ainda são limitados tendo em vista que a toxicologia convencional não avalia os aspectos de morfologia, tamanho da partícula, métodos utilizados para a produção das substâncias no âmbito da nanotecnologia (ALVES, O. L., 2012).

O crescimento da demanda por novos nichos de mercado envolvendo os cosméticos tem promovido diversas pesquisas e inovação de novos ativos e 
matérias-primas em campos correlatos ao setor de cosméticos, sobretudo no que se refere às pesquisas em fármacos e alimentos. Nas últimas décadas, o desenvolvimento de substâncias diferenciadas tem encontrado terreno na intersecção desses setores produtivos, incentivado as indústrias inovarem além de seus limites tradicionais. Além do mais, a inexistência de legislações específicas e as novas demandas e nichos de consumo têm promovido o estreitamento dessas fronteiras. Dentre as inovações mais representativas nessas áreas, destacam-se o campo da dermocosmética com os cosmecêuticos e ainda dos nutricosméticos e nutracêuticos (Figura 4).

Figura 4 - Cosmecêuticos, Nutracêuticos e Nutricosméticos

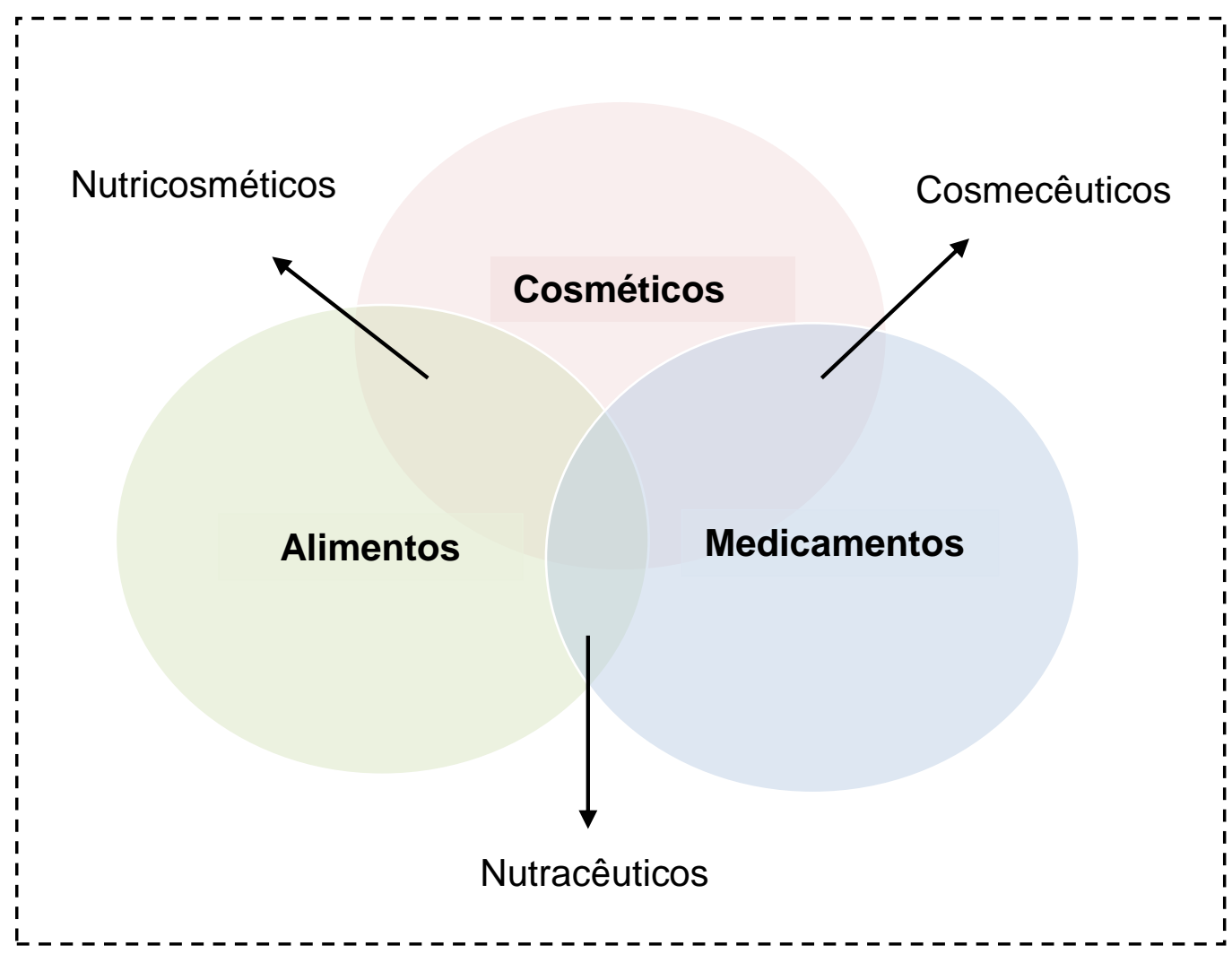

Fonte: MELLAGE, C., 2008 In.: Kline \&Company, 2008. Elaborado pela Autora. 
Os cosmecêuticos ${ }^{11}$ são formulações tópicas de comprovada ação terapêutica e constituem uma combinação (ou híbridos) entre produtos cosméticos e farmacêuticos, cuja interação de seus ingredientes ativos seja benéfica à saúde e ao tratamento estético da pele (sobretudo produtos antiidade), cabelo ou da higiene oral. Considerado por especialistas da área como a vanguarda da indústria cosmética (KLIGMAN, A. M., 2002), os cosmecêuticos são desenvolvidos por tecnologias diferenciadas do setor farmacêutico/cosméticos e os ingredientes ativos aplicados nas formulações apresentam maior eficácia na reparação de tecidos danificados e proteção contra a radiação solar por atuarem nas camadas mais profundas da pele. Além do mais, não demandam prescrição médica, podendo ser adquiridos em diferentes estabelecimentos (drogarias, farmácias, farmácias de manipulação, etc).

Os cosmecêuticos são também denominados de "cosméticos de desempenho", "cosméticos funcionais", "cosméticos ativos" ou "dermocosméticos", sendo esses últimos usualmente receitados por dermatologistas e elaborados em laboratórios farmacêuticos (KLIGMAN, A. M., 2002; Kline \& Company, 2011; FERRO, A. F. P., 2010). Dentre as matériasprimas e ações, ressaltam-se as vitaminas, proteínas e outros ativos vegetais (Quadro 4).

\footnotetext{
${ }^{11}$ Inicialmente, o conceito sobre cosmecêutico foi desenvolvido em 1961, por Raymond Reed, embora seu termo e classificação tenham sido especificados apenas em 1984, por Albert M. Kligman da Faculdade de Medicina, Universidade de Pensilvânia (EUA). Kligman define os cosmecêuticos como produtos aplicados topicamente e capazes de alterar o status da pele (KLIGMAN, 2002).
} 
Quadro 4 - Exemplos de Matérias-primas em Cosmecêuticos

\begin{tabular}{|l|l|}
\multicolumn{1}{|c|}{ Matérias-Primas } & \multicolumn{1}{|c|}{ Ação Cosmética } \\
\hline Vitaminas & Antioxidante \\
\hline Alfa-hidroxiácidos & Esfoliação e melhora da circulação \\
\hline $\begin{array}{l}\text { Ácidos graxos essenciais } \\
\text { (ômegas) }\end{array}$ & Suaviza, hidrata e protege \\
\hline $\begin{array}{l}\text { Coenzima Q10 (ubiquinona) } \\
\text { Ginkgo biloba }\end{array}$ & $\begin{array}{l}\text { Antioxidante celular } \\
\text { promove aparência jovial }\end{array}$ \\
\hline Picnogenol & Efeito anti-aging \\
\hline Betacaroteno & Minimiza a peroxidação lipídica e antioxidante \\
\hline Hialuronato de sódio & $\begin{array}{l}\text { Lubrificante entre os tecidos da pele e } \\
\text { mantém a hidratação natural }\end{array}$ \\
\hline
\end{tabular}

Gonte: Dureja et al., 2005. Apud. ANUNCIATO, T. P.; FILHO, P.A.R.

Os mercados de consumo dos cosmecêuticos são mais expressivos na Ásia e Europa, correspondendo a $70 \%$ do faturamento global desse subsegmento (Cosmetics \& Toiletries, 2009). Registre-se que, originalmente, esses tipos de produtos encontravam-se restritos aos mercados de luxo ou profissionais, entretanto, tem ocorrido uma expansão no consumo e em certa medida uma popularização mediante os mercados de venda direta. Exemplos de empresas que desenvolvem cosmecêuticos são representados pela Colgate-Palmolive, Shiseido, L'Oréal (marca Vichy), entre outros (Kline \& Company, 2008).

Quanto aos nutracêuticos, termo cunhado por Stephen De Felice em 1989, eles são classificados como alimentos ou parte de alimentos que visam proporcionar benefícios à saúde, incluindo a prevenção e/ou tratamento de doenças, podendo ser encontrados naturalmente em determinados alimentos. Pertencem a esse grupo, os nutrientes isolados, extratos vegetais, fibras 
dietéticas, suplementos dietéticos, proteínas, alimentos funcionais, produtos herbais e alimentos processados, como bebidas, cereais e sopas. De acordo com os especialistas do ramo, esses produtos possuem características semelhantes aos cosmecêuticos, na medida em que ao serem ingeridos podem repor minerais e vitaminas, atuam como reparadores da elasticidade da pele e tratam cabelos, unhas, entre outros (DEFELICE, S.,1995).

Os estudos das propriedades nutracêuticas tiveram início nos anos 1980, e voltados para a comprovação clínica da ingestão de cálcio, fibras e óleo de peixe. As empresas do setor de alimentos investem mais neste subsegmento do que os setores de cosméticos e fármacos, tendo em vista a maior proximidade do seu setor produtivo com o desenvolvimento de alimentos funcionais (FERRO, A. F. P, 2010). Dentre as empresas produtoras, destacamse a Danone (francesa), Parmalat (italiana) e Yakult (japonesa).

A preocupação em aliar saúde, um corpo saudável e os cuidados de estética tem exercido forte influência no desenvolvimento de produtos alinhados a essa tendência. Para atender esse mercado, os setores industriais de cosméticos e alimentos passaram a incorporar novas combinações de formulações em produtos acabados, denominados de nutricosméticos, que são produtos administrados oralmente, formulados e comercializados com fins de embelezamento e apresentados na forma de alimentos, pílulas, cápsulas, comprimidos, balas ou líquidos, sendo conhecidos no mercado pelo conceito de "beleza de dentro para fora". Os componentes mais utilizados são as vitaminas, as ervas, os minerais, extratos, proteínas, aminoácidos e as combinações desses ingredientes (MELLAGE, 2008).

De acordo com a EUROMONITOR (2010), o mercado global de nutricosméticos atingiu US\$ 4 bilhões em 2009, correspondendo principalmente 
ao elevado consumo na Ásia e Europa. Dentre os países com destaque, o Japão $^{12}$ posiciona-se como o principal país consumidor de nutricosméticos do mundo, e em seguida, a Alemanha, o Reino Unido e a França. As diversas lojas especializadas em produtos naturais, populares nesses países, fortaleceram o mercado e a comercialização desses suplementos de beleza (Cosmetics \& Toiletries, 2011).

Atualmente, os setores de bebidas e alimentos têm investido em P\&D, incorporando ingredientes da indústria de cosméticos em seus produtos, sobretudo, a partir de formulações com ceramidas, colágeno, antioxidantes, enzimas, etc. Um exemplo representativo das atividades em P\&D nessa área pode ser identificado entre a L'Oréal e Nestlé, que realizaram fusões de seus departamentos em expertises para conceber os laboratórios Innéov. A gigante de cosméticos L'Oréal conduziu as pesquisas demartológicas de ingredientes ativos e seus efeitos biológicos, e a Nestlé desenvolveu pesquisa nutricional e as complementações necessárias para a segurança e a formulação de um nutricosméticos. Em 2008, a marca Innéov lançou no Brasil um produto (Fermeté) com base nas proteínas do leite e um ativo patenteado (lactolicopeno), servindo como antioxidante, acelerador celular e protetor das fibras de colágeno. Além desse produto, já se encontram disponíveis no mercado brasileiro outros diversos tipos de nutricosméticos, com destaque para aqueles da Racco, empresa nacional pioneira no segmento de alimentos funcionais, que desenvolveu em parceria com a farmacêutica norte-americana Pfizer, cápsulas formuladas com colágeno marinho, zinco e vitaminas E e C para a

\footnotetext{
${ }^{12}$ Registre-se, a propósito, a atuação da empresa japonesa Shiseido que desenvolve dezenas de nutricosméticos de alta tecnologia e inovação (Cosmetics \& Toiletries, 2011).
} 
prevenção de rugas e melhorar a vitalidade dos cabelos e unhas (Cosmetics \& Toiletries, 2011).

Embora as perspectivas apontem um futuro promissor nas áreas dos cosmecêuticos, nutracêuticos e nutricosméticos, destacamos que a inexistência de marcos regulatórios e a dificuldade de unificar as legislações específicas desse novo segmento no âmbito global ilustram um quadro preocupante quanto à falta de padrões de referência, rotulagem, segurança, efetividade e toxidade das substâncias. Na Europa, os nutricosméticos, por exemplo, são definidos na categoria de gêneros alimentícios, todavia existe uma lista rigorosa das substâncias (vitaminas e minerais) permitidas em seus respectivos produtos. Nos EUA, durante os anos 1990, o FDA tonou mais difusa a fronteira entre alimentos, drogas e suplementos dietéticos (BIANCO, A. L. 2008), porém até o momento a categoria cosmecêuticos não tem reconhecimento perante a lei americana. Já no Brasil, embora a ANVISA não registre nenhum produto com essas terminologias, ela classifica os nutricosméticos como alimentos funcionais ${ }^{13}$.

\subsection{Bioprospecção e Marcos Regulatórios}

Em relação aos marcos regulatórios sobre a biodiversidade, destacamse a legislação e os procedimentos de acesso ao patrimônio genético e ao conhecimento tradicional associado (CTA) que têm apresentado alguns entraves no que se refere às atividades de bioprospecção no país (COSTA, 2009). O governo federal instituiu o CNPq para a concessão de licenças de

\footnotetext{
${ }^{13} \mathrm{O}$ reconhecimento oficial de alimentos funcionais teve aprovação de legislação especifica em 1999 (ANVISA, 2007).
} 
pesquisas básicas sobre a biodiversidade, entretanto, quando elas envolvem perspectivas de uso comercial é o Conselho de Gestão do Patrimônio Genético (CGEN), órgão colegiado ao MMA criado pelo Decreto 3.945/01, que avalia e autoriza as solicitações. As tramitações dos pedidos de autorização do CGEN são extremamente longas e detalhadas e, dessa forma, os interessados em bioprospecção, especialmente as empresas, têm visto a legislação como um grande obstáculo para o avanço das pesquisas, tornando-as até mesmo inviáveis.

As atividades de bioprospecção consistem na descoberta de informações genéticas, bioquímicas e moleculares de "organismos, genes, enzimas, compostos, processos e partes provenientes de seres vivos em geral, que possam ter um potencial econômico e, eventualmente, levar ao desenvolvimento de um produto" (JUNIOR, N. L. S, 2011, p.7). De modo geral, em uma primeira etapa, a bioprospecção envolve o inventário e a coleta de amostras de plantas, microrganismos ou animais; uma segunda fase abrange a preparação de extratos e por fim as pesquisas de determinação das propriedades bio-físico-químicas e farmacológicas das amostras.

No Brasil, a bioprospecção teve seu conceito definido na versão original da Medida Provisória 2.186-16/01, como sendo: "atividade exploratória que visa identificar componente do patrimônio genético e informação sobre conhecimento tradicional associado, com potencial de uso comercial". Posteriormente, o CGEN estabeleceu nova definição ao considerar os projetos que visem o melhoramento genético vegetal: "etapa na qual os genótipos promissores, selecionados na fase da pesquisa científica, são submetidos a testes de distinguibilidade, homogeneidade e estabilidade (DHE) e de valor de cultivo e uso (VCU), ou ensaios equivalentes" (CGEN/MMA, 2009). 
As legislações e normas nacionais sobre 0 acesso aos recursos genéticos e repartição de benefícios do CTA têm como bases as diretrizes firmadas pela Convenção sobre Diversidade Biológica (CDB), acordo firmado em 1992, durante a Conferência das Nações Unidas para o Meio Ambiente e Desenvolvimento no Rio de Janeiro. Anteriormente à CDB, postulava-se que os recursos biológicos e genéticos eram considerados patrimônios da humanidade, podendo ser acessados em todos os territórios sem distinção. Fins do século $\mathrm{XX}$, os conceitos mudaram e a CDB estabeleceu como uma das diretrizes gerais o reconhecimento da soberania de cada país sobre os recursos genéticos disponíveis em seu território. Essa transformação esteve basicamente associada a uma mudança de paradigmas envolvendo, sobretudo, os países ricos em biodiversidade que se posicionaram contra 0 livre acesso de seus recursos genéticos por empresas de outros países que regularmente transformavam essas fontes em produtos industrializados e patenteados.

Dentre os caminhos que os países signatários deveriam seguir pós$\mathrm{CBD}$, destacaram-se os mecanismos legais de acesso à biodiversidade, repartição de benefícios com as populações e transferência de tecnologia. No Brasil, as primeiras resoluções elaboradas pelo governo federal ocorreram com um projeto de lei de autoria do Senado e do Executivo em 1995, mas que se encontra em tramitação há pelo menos dezessete anos devido as graves divergências entre os Ministérios do Meio Ambiente, Ciência e Tecnologia, Agricultura, entre outros. O projeto de lei tem sido alterado desde sua formulação em busca de atender os diversos conflitos entre os setores envolvidos (governo, comunidade científica, setor industrial, comunidades de 
populações tradicionais, etc.), como também incorporar as demandas surgidas a partir de outros instrumentos normativos em vigor.

Dentre as regulamentações estabelecidas pelo governo federal, a mais emblemática é a MP 2.186-16/01 que define as regras sobre o acesso ao patrimônio genético e a repartição de benefícios do CTA, determinando um conjunto de normas bastante rígidas no que se refere a esses assuntos, sobretudo quando o acesso envolve atividades de bioprospecção e até mesmo com fins de pesquisas científicas. Destaque-se, a propósito, que a edição dessa medida provisória teve como impulso a necessidade de se criar uma lei específica que regulamentasse $\mathrm{o}$ acesso à biodiversidade e às atividades de bioprospecção que estavam em curso no país no fim da década de 1990 . Nessa época, um programa do governo federal voltado para a P\&D de bioprodutos, com destaque para cosméticos e fitomedicamentos, denominado PROBEM (Programa Brasileiro de Ecologia Molecular para o Uso Sustentável da Biodiversidade da Amazônia) e a Organização Social Bioamazônia (Associação Brasileira para Uso Sustentável da Biodiversidade da Amazônia) visavam implementar uma série de ações voltadas a criação de uma rede de bioprospecção e o estabelecimento de parcerias com instituições de pesquisa, empresas do setor e comunidades da região ${ }^{14}$. Todavia, a inexistência de

\footnotetext{
${ }^{14}$ O PROBEM foi estruturado em 1995 por um grupo de pesquisadores de diversas instituições brasileiras da área da bioprospecção, envolvendo os campos de farmacologia, botânica, química de produtos naturais, bioquímica, entre outras. As estratégias principais apoiavam-se na formação e a gestão de uma rede integrada de pesquisadores e laboratórios nacionais em bioprospecção que deveria atuar desde a fase do inventário biológico da biodiversidade amazônica até as etapas de P\&D, patenteamento, licenciamento e comercialização dos bioprodutos. Além do mais, promoveria a melhoria da infraestrutura das instituições envolvidas nas áreas de produtos naturais e biotecnologia, no incentivo das bioindústrias da região, a construção de um centro de biotecnologia em Manaus, dentre outros.

Já a Bioamazônia, mediante um Contrato de Gestão, implementaria parte do PROBEM, sobretudo as ações vindas à rede de bioprospecção, a capacitação de recursos humanos locais, a elaboração do layout das instalações e equipamentos do Centro de Biotecnologia da Amazônia (CBA), a gestão de processos de proteção da propriedade intelectual e industrial, o estabelecimento de parcerias com as comunidades para a coleta da biodiversidade e com
} 
marcos regulatórios sobre o uso econômico da biodiversidade, como também a falta de regras sobre a repartição de benefícios oriundo do conhecimento tradicional associado, levaram a extinção do programa e o encerramento das negociações entre as partes envolvidas (COSTA, W. M., 2009; MIGUEL, L. M., 2007).

Um exemplo recente dos entraves sobre o acesso aos recursos genéticos pode ser citado com um dos processos da empresa Natura, multada em $\mathrm{R} \$ 21$ milhões pelo IBAMA no fim de 2010 devido a suposto acesso irregular da biodiversidade brasileira e ao CTA. Nesse caso, a empresa não teria aguardado os longos trâmites de liberação e autorização, que podem demorar até dois anos, decidindo desenvolver as pesquisas de um novo princípio ativo para uso comercial sem o consentimento prévio concedido pelo CGEN. De acordo com a empresa, dois anos equivaleria ao ciclo de vida de um produto no mercado e milhares de recursos investidos nas pesquisas poderiam ser perdidos. Além da Natura, outras empresas nacionais e internacionais envolvidas em atividades de bioprospecção no país, como instituições de pesquisas ou pesquisadores, também já foram autuados pelo IBAMA, contabilizando valores acima de $\mathrm{R} \$ 100$ milhões de multas por acessos irregulares, sendo $60 \%$ delas associadas exclusivamente à Natura (BARROS, G., 2010).

empresas dos setores, dentre outras. Um dos projetos de cooperação seria firmado com uma grande empresa farmacêutica, a suíça Novartis Pharma, visando a coleta, identificação e busca de princípios ativos localizados na floresta amazônica e, em contrapartida, o projeto previa a doação de recursos financeiros para aquisição de equipamentos do CBA, a capacitação de pesquisadores do país, transferências de tecnologias e o compartilhamento de possíveis resultados financeiros (royalties) oriundos da comercialização dos bioprodutos finais. Devido às críticas de diversos setores, a falta de uma legislação sobre o tema e a dificuldade de definição de arranjos políticos e institucionais, a maior iniciativa brasileira de se implantar uma consolidada rede de pesquisas em P\&D de ativos da biodiversidade propiciou poucos dos resultados esperados. Dentre os aspectos positivos, destacam-se a elaboração da MP 2.186/01 e da construção do CBA (MIGUEL, L. M., 2007). 
Esse quadro exemplifica como as grandes empresas têm enfrentado as normas burocráticas do sistema brasileiro de acesso aos recursos genéticos. Em razão das diversas impropriedades das normas adotadas pelo governo federal que regulam o assunto, observamos, por um lado, a tendência das grandes empresas de cosméticos assumirem os riscos de autuações para o avanço das pesquisas sobre o uso da biodiversidade; mas por outro lado, verificamos, na prática, restrições muito rígidas não apenas para as atividades de bioprospecção dessas mesmas empresas líderes, como também, e principalmente, enormes barreiras para as pequenas empresas e as atividades com fins de pesquisa científica ou tecnológica.Uma breve consulta dos processos enviados por diversas instituições, pesquisadores e empresas ao CGEN demonstra que apenas uma pequena parcela dos pedidos tem sido autorizada para esses fins, revelando as burocracias e o rigor do sistema normativo brasileiro (Tabela 7).

Tabela 7 - Processos autorizados pelo CGEN entre 2002 e 2010

\begin{tabular}{|l|c|}
\hline \multicolumn{1}{|c|}{ Processos Autorizados } & Quant. \\
\hline Pesquisa científica com CTA & 40 \\
\hline Pesquisa científica com CTA e patrimônio genético & 7 \\
\hline Bioprospecção com patrimônio genético & 12 \\
\hline Bioprospecção com patrimônio genético (autorização especial) & 1 \\
\hline Desenvolvimento tecnológico com patrimônio genético & 10 \\
\hline Bioprospecção e desenvolvimento tecnológico com patrimônio genético & 10 \\
\hline Bioprospecção com patrimônio genético e CTA & 2 \\
\hline Desenvolvimento tecnológico com patrimônio genético e CTA & 0 \\
\hline Bioprospecção e desenvolvimento tecnológico com patrimônio genético e CTA & 0 \\
\hline Constituição de coleções ex situ com potencial de uso econômico & 3 \\
\hline Total de solicitação de autorização & $\mathbf{7 3}$ \\
\hline Total de solicitações de autorização para regularização & $\mathbf{3 2}$ \\
\hline Total de renovações de autorização & $\mathbf{1 5}$ \\
\hline Fonte: CGEN, & 1011. \\
\hline
\end{tabular}


Finalmente, além das dificuldades de regulação existentes, há que se destacar também a inexistência de punições para os que acessam, sem consentimento prévio, os recursos genéticos em territórios do país detentor. As negociações em torno dessas questões e do acesso e repartição de benefícios (denominado de ABS - Acess and Benefit Sharing), certamente um dos lados mais sensíveis das discussões envolvendo a bioprospecção, têm sido mediadas atualmente no âmbito internacional com o Protocolo de Nagoya ${ }^{15}$ (2010), que estabelece as bases para os países signatários construírem um arcabouço institucional para coibir a apropriação ilegal de informação e material biológico (biopirataria internacional) e fornecer maior segurança jurídica aos envolvidos com a bioprospecção. Além do mais, o Protocolo tem como ponto central tentar introduzir uma mudança de paradigmas nos debates de ABS que se arrastam há dezoito anos, uma vez que envolver populações tradicionais nas questões de uso comercial da biodiversidade e do conhecimento associado também tem sido uma das questões de maior complexidade no conjunto desses temas.

As defasagens e diferenças entre os compromissos internacionais e as legislações nacionais implementadas em cada país também refletem o grau de conflito a respeito do uso e do acesso à biodiversidade. Evidentemente que o caminho dos acordos e metas definidas nos diversos instrumentos internacionais e nacionais ainda será muito longo devido às dificuldades de conciliar tantos interesses em uma mesma agenda. Esses assuntos não contemplam somente os limites legais da área ambiental, eles produzem

\footnotetext{
${ }^{15}$ Em outubro de 2010, o Protocolo de Nagoya foi firmado por 192 países durante a Convenção da Biodiversidade da ONU (COP-10 - Conferência das Partes da Convenção sobre Diversidade Biológica) no Japão. Para entrar em vigor são necessárias 50 ratificações. Até o momento, 92 países assinaram o Protocolo, porém somente 5 países o ratificaram, o Brasil é um deles (Fórum Amazônia Sustentável, 2012).
} 
impactos diretos nos setores da saúde, agrícola e de outros diversos campos tecnológicos e científicos, como também nas esferas políticas, sociais e territoriais. 


\section{CAPítUlO 4 - TENDÊNCIAS E PERSPECTIVAS DO SEGMENTO DE BIOCOSMÉTICOS: panorama internacional e nacional}

Uma das tendências em curso associada à cadeia produtiva dos cosméticos pode ser verificada com a expansão dos modelos alternativos de uso dos recursos naturais, que introduz para esse segmento industrial novos nichos de mercado, como o "mercado verde" e o "mercado bio" movidos dessa forma pela demanda de produtos ambientalmente e socialmente sustentáveis.

Os produtos desenvolvidos com ativos naturais refletem e sinalizam um novo paradigma e novas tendências, sendo os hábitos e os padrões de consumo da população determinantes de um crescimento do que Dweck (1999) denomina de "indústria da beleza". Essa indústria envolve desde a produção de cosméticos com propriedades básicas e de usos mais difundidos, como também de produtos de luxo altamente sofisticados, além dos serviços oferecidos por salões de beleza, clínicas de estéticas e dos "spas", considerados um dos circuitos "vip's" dessa indústria.

Dessa forma, a demanda por bioprodutos está associada basicamente à crescente sofisticação dos mercados consumidores e o interesse pelo que é saudável e natural, à entrada de grandes empresas do setor nesse segmento, ao marketing, às mudanças nos indicadores demográficos com o envelhecimento da população de um modo geral e ao crescimento do interesse por produtos terapêuticos, como os produtos híbridos (fármacos e cosméticos), conhecidos por cosmecêuticos, denominados também de dermocosméticos ou cosméticos funcionais. 
A participação dos produtos naturais pode ser ainda discreta se comparada ao volume total de consumo da indústria de higiene pessoal, perfumaria e cosméticos em geral, no entanto, como o segmento contava até recentemente com pouquíssimas empresas especializadas nessa estratégica área, as estimativas apontam perspectivas favoráveis de crescimento dessas novas tendências de mercado.

Tomando como base a experiência acumulada na área de C\&T e os estudos de mercado realizados até o momento, diversas matérias-primas, além das tradicionais, demonstram viabilidade técnica, econômica e industrial, tendo como referenciais as espécies vegetais, com destaque para as matérias-primas da flora tropical, e ainda também os pigmentos de ativos minerais, como das argilas. Como visto, além dos produtos de higiene pessoal, perfumaria e cosméticos, essas espécies apresentam múltiplas formas de aplicações para o aproveitamento industrial, sobretudo para o desenvolvimento de insumos e extratos padronizados, nutracêuticos, produtos alimentícios, fitomedicamentos, enzimas de interesse industrial, corantes, flavorizantes e conservantes.

Nos cosméticos, os componentes naturais são mais significativos em determinadas categorias e linhas de produtos e apresentam-se mais concentrados nos produtos de cuidado com a pele, seguidos dos produtos para cabelo e banho (JONES, A. e DUERBECK, K., 2004). Entretanto, há que se destacar as diferenças entre os cosméticos naturais/orgânicos e os cosméticos com ativos naturais, isto é, aqueles produtos que contém em suas composições ingredientes de origem natural, mas que apresentam também em suas propriedades variados graus e concentrações de componentes sintéticos, químicos e conservantes necessários para manter a estabilidade e durabilidade dos produtos (Quadro 5). 


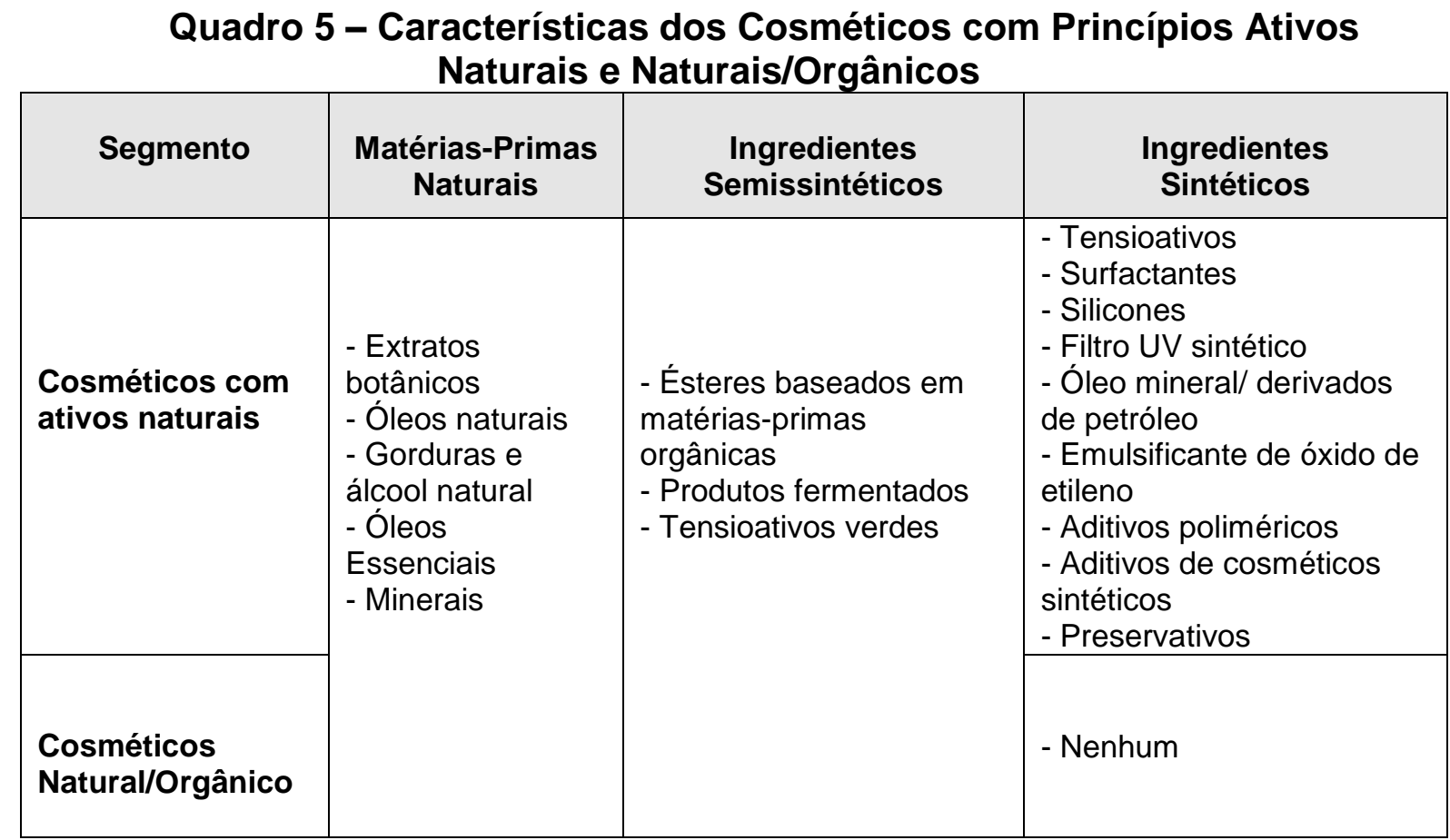

Fonte: Adaptado de Kline \& Company (2008). Elaborado pela autora, 2012.

Se de um lado, os padrões restritivos de legislação sanitária e de limitação do uso de alguns conservantes - caso emblemático dos parabenos, que depois de inúmeras pesquisas têm sido apontados como nocivos à saúde (Anexo 6) - por outro, as atividades microbiológicas tendem a ser mais aceleradas em produtos com formulação 100\% natural e estão assim sujeitas a diversas limitações de validade, consistência, textura e coloração, restringindo a sua produção e o seu consumo. Se em tese os produtos naturais podem ser considerados menos agressivos, eles também requerem criteriosas comprovações de análise e normatização em todas as etapas, sobretudo, no que diz respeito à segurança dos insumos aplicados nos produtos finais. Dessa forma, pode-se inferir que parte dos cosméticos denominados "naturais" e que são comercializados por muitas empresas contém muito mais um apelo e um slogan para o consumidor do que de fato produtos formulados integralmente com base em ativos naturais, isto é, isentos de substâncias químicas sintéticas. 


\subsection{O Segmento de Biocosméticos: quadro geral}

No mundo, estima-se que o mercado de cosméticos naturais, em 2010, movimentou cerca de US\$10 bilhões (ORGANIC MONITOR, 2011), o que representou $2,5 \%$ do mercado global de produtos de beleza e higiene. No entanto, outros estudos apontam um cenário ainda mais promissor, indicando que esse segmento movimentou mais de US $\$ 23$ bilhões no último ano e registrou um crescimento de 15\% (Kline \& Company, 2011; Gráfico 18).

\section{Gráfico 18 - Evolução do Mercado de Biocosméticos no Mundo entre 2005 e 2010 (bilhões de US\$)}

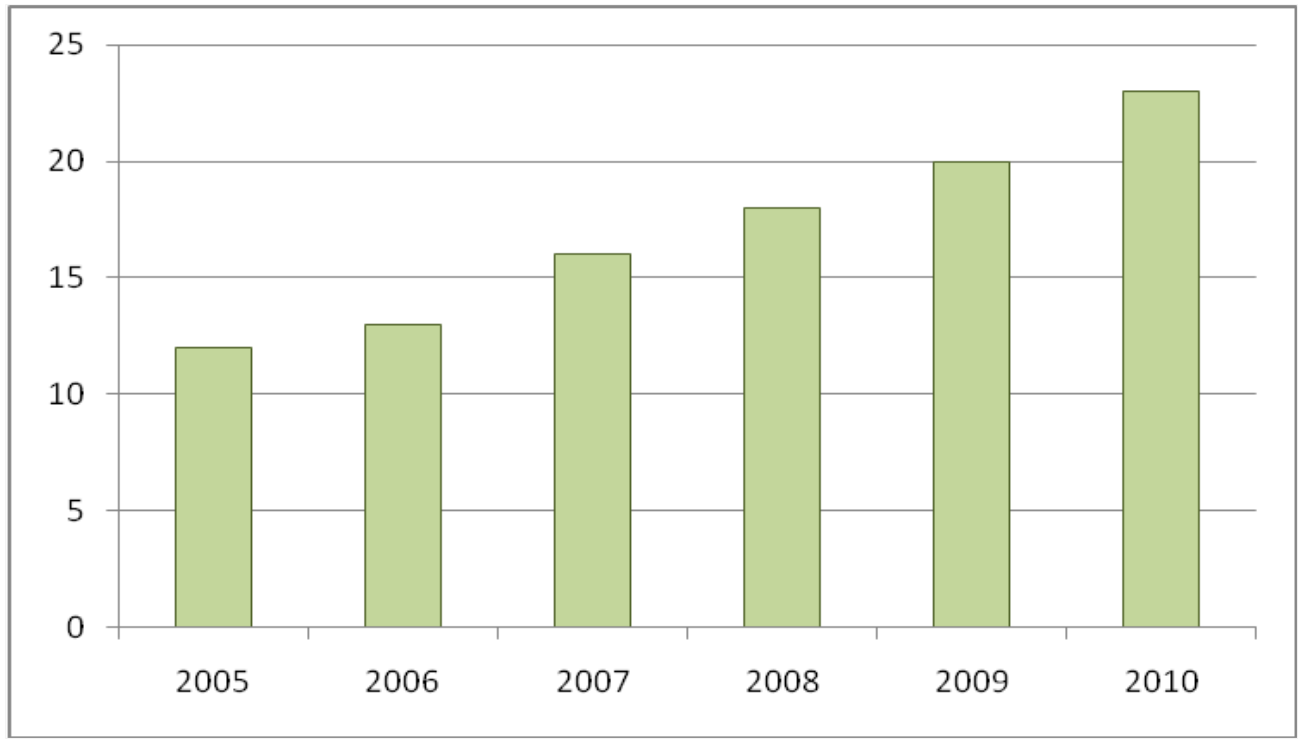

Fonte: Kline \& Company, 2011. Elaborado pela Autora.

Segundo os grandes blocos de mercado regional no mundo, os países asiáticos e do pacífico lideram o consumo de produtos naturais. No entanto, o país que concentra o maior volume de vendas desses tipos de produtos são os EUA. Nesse país, o mercado envolveu US\$3,8 milhões em 2010, crescendo $12 \%$ em relação ao ano anterior e sendo estimado um total de US $\$ 6,7$ bilhões para 2015. Dentre os países da União Europeia, destacam-se especialmente a 
Alemanha, França, Reino Unido, Itália e Espanha. Entre 2009 a 2010, o mercado europeu apresentou crescimento de $11,7 \%$ e deverá alcançar nos próximos anos $€ 6$ bilhões. Ademais, o mesmo estudo aponta que os países asiáticos e o Brasil lideram o crescimento deste tipo de mercado, sendo esperado para esta década um crescimento de $10 \%$ a $20 \%$ nesses países (Kline \& Company, 2011; Gráfico 19).

\section{Gráfico 19 - Crescimento do Segmento de Biocosméticos no mundo entre 2009/2010}

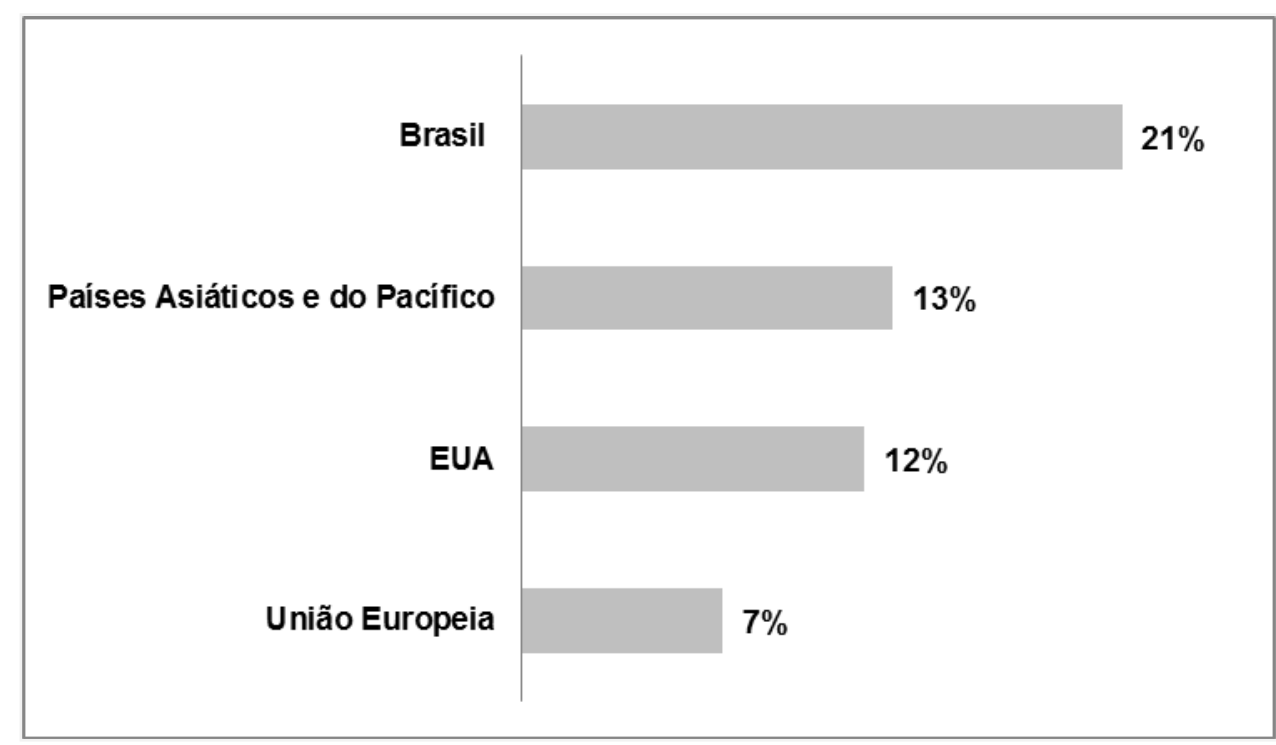

Fonte: Kline \& Company, 2011. Elaborado pela Autora.

O elevado consumo de cosméticos naturais e orgânicos nos países da Europa, EUA e Japão está diretamente associado ao impulso do consumo de alimentos orgânicos desde a década de 1990. Questões vinculadas à sustentabilidade, saúde, bem-estar e segurança alimentar passaram a nortear o comportamento de significativas parcelas de consumidores nesses países, como apresentamos no Capítulo 1 desta tese. De modo geral esses consumidores são mais exigentes e, no Brasil, os estudos do setor apontam que este é um mercado interno ainda reduzido, mas em crescimento e sua expansão dependerá de uma maior pressão do consumidor (LAYRARGUES, P. 
P., 2000). Uma pesquisa desenvolvida pela Union for Ethical BioTrade ${ }^{16}$ (UEBT), demonstra que o consumidor brasileiro tem fortemente valorizado o consumo consciente, assim como os ingredientes naturais e a origem das matérias-primas utilizadas em cosméticos. Seus resultados apontam que $85 \%$ dos consumidores dão importância aos produtos cosméticos com ativos naturais e 69\% estão atentos à origem dos ingredientes (UEBT, 2012) ${ }^{17}$.

No que diz respeito aos canais de vendas dos biocosméticos, observamos significativas diferenças de atuação das empresas nos países selecionados. O Gráfico 20 apresenta a distribuição das vendas no Brasil, EUA e países da Europa. No caso do Brasil, a maior parcela da distribuição de biocosméticos é realizada por venda direta, cujas bases estão diretamente associadas as estratégias de negócios da maior empresa nacional atuante no segmento de produtos derivados da biodiversidade no mercado brasileiro, a Natura. A representatividade da comercialização e dos canais de vendas utilizados pelo segmento na Europa e EUA é notadamente diferente do modelo brasileiro, sobretudo pela existência de lojas especializadas em produtos naturais e dos hipermercados e mercados que também disponibilizam esses produtos e até mesmo desenvolvem marcas próprias de bioprodutos em geral.

\footnotetext{
${ }^{16}$ A UEBT, fundada em 2007, é uma associação internacional com atuação no Brasil e em diversos países. Visa implementar junto a diferentes agentes da cadeia produtiva a comercialização da biodiversidade segundo critérios de sustentabilidade. A UBET reúne produtores, cooperativas, empresas processadoras de insumos e produtos acabados, associações comerciais e instituições de pesquisa buscando promover o abastecimento da cadeia a partir do biocomércio ético (UEBT, 2012).

17 Ressalta-se, entretanto, que essa pesquisa, denominada "Barômetro da Biodiversidade, é realizada via questionário internet, limitando os resultados finais da amostra. Indicadores do Centro de Estudos sobre Tecnologias da Informação e Comunicação apontam que são considerados usuários da rede mundial de computadores aqueles que acessaram a rede pelo menos uma vez nos últimos três meses. Os indicadores informam que esse percentual foi de $45 \%$ do total da população brasileira (CGI, 2012) e, desse modo, os resultados amostrados na pesquisa do barômetro representam apenas alguns perfis específicos de consumidores e não todo universo de consumidores no país.
} 
Além disso, as farmácias também detêm peso importante nos canais de venda nos países europeus.

\section{Gráfico 20 - Distribuição de Biocosméticos no Brasil, nos EUA e na Europa em 2009}

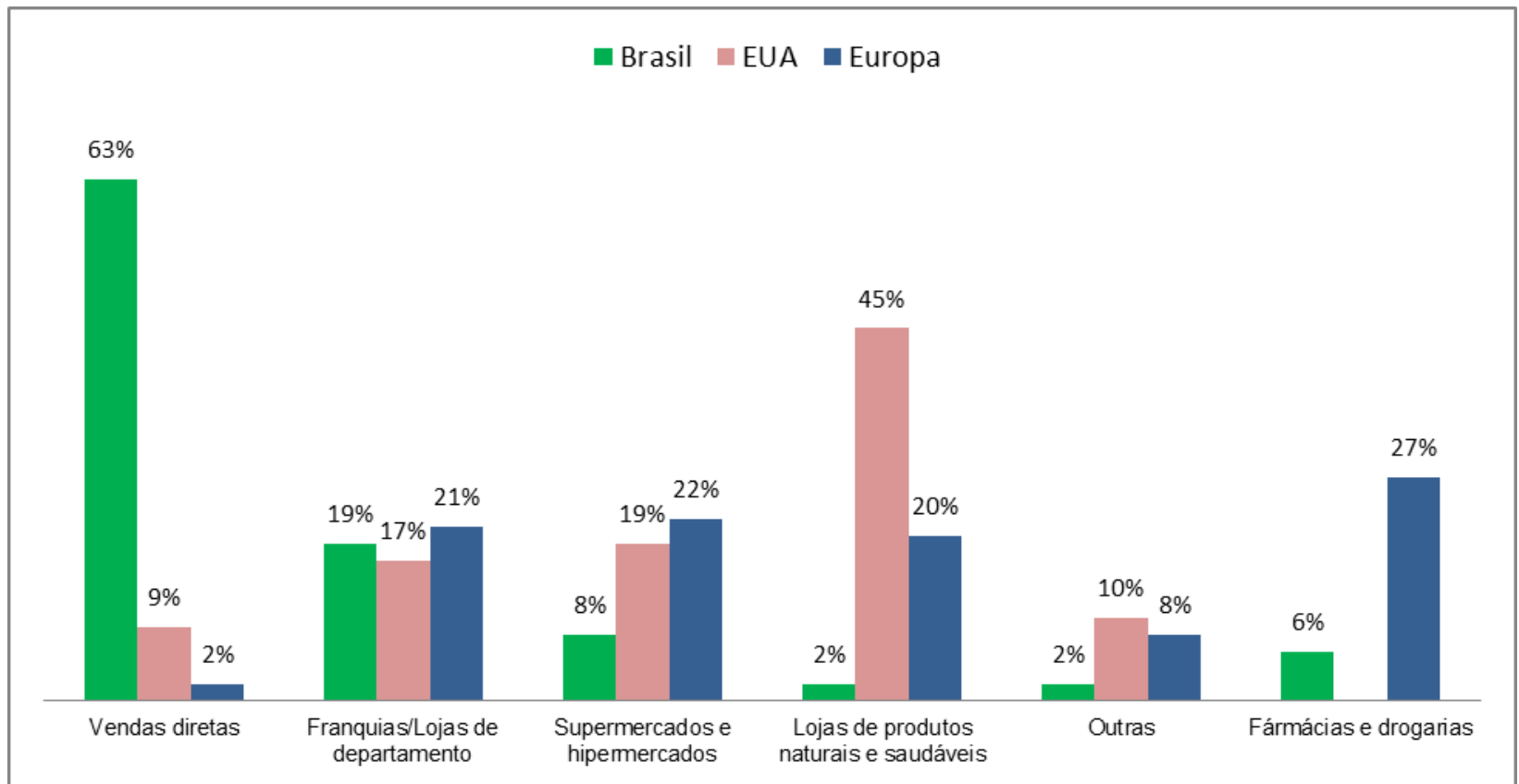

Fonte: Kline \& Company, 2011. Elaboração da Autora.

\subsection{Dinâmica de Produção e Distribuição de Matérias-Primas}

\section{Tradicionais e Inovadoras}

Um estudo realizado por especialistas em óleos, essências e aromas para os setores industriais de cosméticos aponta que $90 \%$ dos óleos essenciais consumidos no mundo têm origem em áreas de cultivo na Índia, Indonésia, China e no Brasil (SHRINIVAS, P., KUDLI, A, 2009). Registre-se que a Índia e a China têm tradição milenar na produção de plantas medicinais e aromáticas e que são amplamente utilizadas em diversos tratamentos de fitoterapia, em produtos homeopáticos e outros setores industriais.

A Tabela 8 apresenta os principais países exportadores de óleos, resinas e terpênicos e indica que parte deles também apresenta altos valores 
de importação, tendo em vista os valores negativos das balanças comerciais para esses tipos de insumos. Dentre eles, destacam-se os principais países produtores de cosméticos, que além de exportarem muito, também precisam importar diversos insumos para a elaboração dos produtos finais, como os EUA, a França, o Reino Unido e a Alemanha. O Brasil encontra-se na quarta posição entre os maiores exportadores de óleos essenciais (COMTRADE, 2012).

Tabela 8 - Principais Países Exportadores de Óleos Essenciais, Resinas e Terpênicos em 2011

\begin{tabular}{|c|c|c|c|c|c|c|}
\hline Ranking & País & $\begin{array}{c}\text { Valor } \\
\text { exportado } \\
\text { (milhões } \\
\text { de US\$) }\end{array}$ & $\begin{array}{l}\text { Quant.* } \\
\text { (ton) }\end{array}$ & $\begin{array}{c}\text { Taxa de } \\
\text { crescimento } \\
\text { anual entre } \\
2007-2011\end{array}$ & $\begin{array}{l}\text { Participação } \\
\text { das } \\
\text { exportações } \\
\text { Mundiais }\end{array}$ & $\begin{array}{c}\text { Saldo } \\
\text { Comercial }\end{array}$ \\
\hline 1 & EUA & 472 & 33.815 & 3 & 13 & -205 \\
\hline 2 & India & 453 & - & 13 & 12,5 & 362 \\
\hline 3 & França & 295 & 5.410 & 3 & 8,1 & -51 \\
\hline 4 & Brasil & 263 & 59.443 & 13 & 7,3 & 199 \\
\hline 5 & China & 226 & 14.072 & 20 & 6,2 & 63 \\
\hline 6 & $\begin{array}{l}\text { Reino } \\
\text { Unido }\end{array}$ & 213 & 7.575 & 13 & 5,9 & -48 \\
\hline 7 & Argentina & 195 & 7.115 & 11 & 5,4 & 175 \\
\hline 8 & Alemanha & 167 & 8.432 & 11 & 4,6 & -84 \\
\hline 9 & Indonésia & 161 & 4.359 & - & 4,4 & 103 \\
\hline 10 & Cingapura & 121 & - & 10 & 3,3 & -45 \\
\hline \multicolumn{2}{|c|}{ Total Mundial } & 3.633 & - & 9 & 100 & 14 \\
\hline
\end{tabular}

Fonte: COMTRADE, 2012. *: Quantidade Estimada.

A Agência CBI (Center for the Promotion of Imports from Developing Countries), criada em 1971, e vinculada ao Ministério de Relações Exteriores do governo da Holanda, atua como articuladora de negócios, marketing e 
exportação das organizações e empresas de 'países emergentes' com a União Europeia (UE). A Agência fornece assistência técnica e subsídios quanto às exigências e aos regulamentos para a entrada de novas matérias-primas (como também das convencionais) no mercado europeu, sendo o setor de cosméticos, perfumaria e produtos de higiene pessoal, uma das áreas priorizadas nos estudos de mercado, com foco para o segmento de produtos naturais.

A rede de fornecedores é formada por mais de cinquenta países, especialmente dos continentes Africano e Asiático, como também da América do Sul e Central. O Brasil ainda não integra oficialmente o grupo de negócios, no entanto aparece com destaque nas trocas comerciais de produtos naturais com a UE. Dentre os produtos mais fornecidos por esses países, sobressaem os grupos dos óleos vegetais de coco, rícino e amendoim e, ainda, dos óleos essenciais de jasmim, vetiver, gerânio e lima. Os dados de 2003 apontam que os países emergentes forneceram pelo menos $50 \%$ do valor total de suas exportações para os membros da UE (CBI, 2005). Os países que mais participam do comércio são a China, a Índia, o Brasil, a Argentina, a Indonésia e o Marrocos, sendo que os maiores compradores de ingredientes naturais para cosméticos são a Alemanha, França, Reino Unido, Espanha, Itália e Polônia (Anexo 7). A Tabela 9 ilustra os principais fornecedores das matériasprimas mais comercializadas nos países da União Europeia. 
Tabela 9 - Principais Matérias-Primas Comercializadas na União Europeia em 2003 (em milhões de euros)

\begin{tabular}{|c|c|c|c|}
\hline Produtos & $\begin{array}{l}\text { Valor da } \\
\text { produção } \\
\text { Total }\end{array}$ & $\begin{array}{l}\text { \% do } \\
\text { Comércio } \\
\text { com a UE }\end{array}$ & $\begin{array}{l}\text { Principais exportadores para a UE } \\
\text { (\% do total) }\end{array}$ \\
\hline Óleo de Ricíno & 77,070 & $78 \%$ & Índia (99\%), Brasil (1\%) \\
\hline Óleo de coco & 573,941 & $78 \%$ & $\begin{array}{l}\text { Indonésia (44\%), Filipinas (38\%), Malásia } \\
(10 \%) \text {, Papuá Nova Guiné }(7 \%)\end{array}$ \\
\hline Óleo de Jasmim & 3,764 & $74 \%$ & $\begin{array}{l}\text { İndia (44\%), Egito (44\%), Marrocos (11\%), } \\
\text { Madagascar ( } 1 \%)\end{array}$ \\
\hline Óleo de Vetiver & 3,855 & $73 \%$ & $\begin{array}{l}\text { Haiti (83\%), Indonésia (9\%), Madagascar } \\
(4 \%) \text {, China (1\%), Paraguai (1\%) }\end{array}$ \\
\hline $\begin{array}{l}\text { Óleo de } \\
\text { Amendoim }\end{array}$ & 112,936 & $63 \%$ & $\begin{array}{l}\text { Senegal (41\%), Argentina (37\%), China } \\
(8 \%) \text {, Índia (5\%), Brasil (5\%), Gâmbia (1\%) }\end{array}$ \\
\hline Óleo de Gerânio & 5,275 & $62 \%$ & $\begin{array}{l}\text { Egito (56\%), China (37\%), África do Sul } \\
(4 \%) \text {, Tunísia (2\%), Madagascar (1\%) }\end{array}$ \\
\hline Óleo de Lima & 9,134 & $50 \%$ & $\begin{array}{l}\text { México }(66 \%) \text {, Peru }(24 \%) \text {, Brasil }(6 \%) \text {, } \\
\text { Cuba }(1 \%) \text {, China }(1 \%)\end{array}$ \\
\hline Ceras & 16,365 & $49 \%$ & $\begin{array}{l}\text { China }(40 \%) \text {, Brasil (39\%), México }(9 \%) \text {, } \\
\text { àfrica central }(2 \%) \text {, Costa do Marfim (2\%), } \\
\text { Etiópia }(2 \%) \text {, Tanzânia }(1 \%)\end{array}$ \\
\hline $\begin{array}{l}\text { Plantas } \\
\text { Medicinais e } \\
\text { Aromáticas }\end{array}$ & 138,141 & $49 \%$ & $\begin{array}{l}\text { China }(17 \%) \text {, India }(10 \%) \text {, Marrocos }(9 \%) \text {, } \\
\text { Egito }(8 \%) \text {, Quênia }(6 \%) \text {, Turquia }(6 \%) \text {, } \\
\text { África do Sul }(5 \%)\end{array}$ \\
\hline $\begin{array}{l}\text { Outros Óleos } \\
\text { Essenciais }\end{array}$ & 112,421 & $47 \%$ & $\begin{array}{l}\text { China (28\%), Indonésia (14\%), Turquia } \\
(10 \%) \text {, Îndia (9\%), Marrocos (8\%), } \\
\text { Madagascar (4\%), Egito (3\%) }\end{array}$ \\
\hline Óleo de Limão & 15,421 & $42 \%$ & $\begin{array}{l}\text { Argentina }(77 \%) \text {, Brasil (8\%), México (7\%), } \\
\text { Costa do Marfim (3\%), Âfrica do Sul (1\%), } \\
\text { Vietnã (1\%), Cuba (1\%) }\end{array}$ \\
\hline $\begin{array}{l}\text { Algas e Plantas } \\
\text { marítimas }\end{array}$ & 21,913 & $35 \%$ & $\begin{array}{l}\text { Filipinas (31\%), China (17\%), Indonésia } \\
(14 \%) \text {, Chile (13\%), Marrocos (10\%), Malásia } \\
(10 \%)\end{array}$ \\
\hline $\begin{array}{l}\text { Manteiga e óleo } \\
\text { de cacau }\end{array}$ & 372,185 & $35 \%$ & $\begin{array}{l}\text { Costa do Marfim (44\%), Indonésia (10\%), } \\
\text { Malásia }(7 \%) \text {, Gana }(6 \%) \text {, Nigéria }(6 \%) \text {, } \\
\text { Turquia }(5 \%)\end{array}$ \\
\hline Corantes & 43,535 & $23 \%$ & $\begin{array}{l}\text { Peru (34\%), China (19\%), Índia (15\%), } \\
\text { México }(8 \%) \text {, África do Sul (6\%), Zimbábue } \\
(4 \%) \text {, Quênia (3\%) }\end{array}$ \\
\hline $\begin{array}{l}\text { Outros Óleos } \\
\text { Essenciais de } \\
\text { Cítricos }\end{array}$ & 3,343 & $17 \%$ & $\begin{array}{l}\text { Cuba (29\%), Brasil (23\%), Tunísia (18\%), } \\
\text { África do Sul (11\%), Argentina (5\%), Costa } \\
\text { do Marfim (4\%) }\end{array}$ \\
\hline
\end{tabular}

Fonte: EUROSTAT, 2004. Adaptação da Autora.

Do ponto de vista da produção nacional, as essências com participação mais expressivas no Brasil são os óleos associados aos frutos cítricos. O país 
tem posição de destaque na produção das quatro principais essências comercializadas internacionalmente, como o óleo de laranja, hortelã, limão e eucalipto. Os cultivos encontram-se distribuídos em diversas partes do país, com destaque para as produções de laranja e limão no estado de São Paulo; hortelã/menta, no Paraná; e o óleo de eucalipto nas plantações e áreas de reflorestamento em diferentes localidades.

A abundância do cultivo dessas espécies enquadra o país entre os principais produtores e exportadores mundiais de produtos brutos e semiprocessados, classificando-se atualmente como o quarto maior exportador de óleos essenciais e detentor de $5 \%$ do mercado global (Tabela 10). Dentre os produtos, o óleo de laranja desponta na pauta de exportação mundial por estar fortemente vinculado à produção de cítricos destinada às indústrias de sucos. Pelo menos $35 \%$ das exportações mundiais da essência de laranja são realizadas pelo Brasil e comercializadas especialmente nos EUA, na Holanda, no Reino Unido, na Alemanha, Índia e China. Em 2011, esse comércio proporcionou ao país mais de US\$ 111 milhões e 24 milhões de toneladas foram exportadas (MDIC, 2012).

Tabela 10 - Importações e Exportações de Óleos Essenciais do Brasil em 2011 (milhões de US\$ e toneladas)

\begin{tabular}{|l|c|c|c|c|c|}
\hline \multirow{2}{*}{ Matéria-Prima } & \multicolumn{2}{c|}{2011} & \multicolumn{2}{c|}{$\begin{array}{c}\text { Variação (\%) entre } \\
\mathbf{2 0 0 7 / 2 0 1 1}\end{array}$} \\
\cline { 2 - 6 } & US\$ & Quantidade & US\$ & Quantidade \\
\hline \multirow{2}{*}{$\begin{array}{l}\text { Óleo essencial } \\
\text { de Laranja }\end{array}$} & Importação & 3.922 & 312 & $21 \%$ & $20 \%$ \\
\cline { 2 - 6 } & Exportação & 111.573 & 24.148 & $10 \%$ & $-6 \%$ \\
\hline \multirow{2}{*}{$\begin{array}{l}\text { Óleo essencial } \\
\text { de Limão }\end{array}$} & Importação & 5.374 & 157 & $-19 \%$ & $-25 \%$ \\
\cline { 2 - 6 } & Exportação & 6.032 & 182 & $2 \%$ & $-15 \%$ \\
\hline \multirow{2}{*}{$\begin{array}{l}\text { Outros óleos } \\
\text { essenciais }\end{array}$} & Importação & 3.290 & 85 & $-5 \%$ & $-17 \%$ \\
\cline { 2 - 6 } & Exportação & 10.925 & 510 & $20 \%$ & $13 \%$ \\
\hline
\end{tabular}




\begin{tabular}{|l|c|c|c|c|c|}
\hline \multirow{2}{*}{ Hortelã-Pimenta } & Importação & 2.392 & 53 & $2 \%$ & $-17 \%$ \\
\cline { 2 - 6 } & Exportação & 423 & 25 & $11 \%$ & $24 \%$ \\
\hline \multirow{3}{*}{ Total de óleos } & Importação & 63.811 & 2.518 & $2 \%$ & $-4 \%$ \\
\cline { 2 - 6 } & Exportação & 263.430 & 59.443 & $13 \%$ & $-5 \%$ \\
\hline
\end{tabular}

Fonte: MDIC, 2012; COMTRADE, 2012.

Exemplos de sistemas produtivos no Brasil em torno dos óleos essenciais podem ser vistos a partir dos acordos de empresas brasileiras com grupos estrangeiros para a exportação de óleo de laranja, por exemplo, com o fornecimento de grande quantidade desse tipo de óleo para o desenvolvimento de perfumes e essências em indústrias francesas. Uma dessas parcerias é formada com a empresa Citrovita, uma das maiores produtoras de concentrados e congelados de laranja do país, do Grupo Votorantim.

Além dos insumos mais comercializados, outros óleos e extratos vegetais apresentam grande demanda de mercado, como os óleos de rosa, jasmim, vetiver, baunilha, camomila e sândalo. No entanto, aspectos relacionados à disponibilidade de matérias-primas, custos de produção e restrições quanto as suas aplicações e formulações, acabam reduzindo a participação desses recursos nos setores industriais. Há que se destacar também a falta de dados estatísticos sobre determinadas matérias-primas, constituindo uma limitação para o conhecimento pleno de seus sistemas produtivos.

No que se refere aos produtos naturais da biodiversidade brasileira, com destaque para os insumos da biodiversidade amazônica, observamos duas tendências simultâneas em curso de circuitos de produção nessa área: i) os sistemas típicos e extrativistas das populações tradicionais amazônicas, 
organizadas sob a forma de trabalho familiar e/ou comunitário e conectados aos mercados de produção regional e nacional; ii) os sistemas produtivos emergentes, expressos sob redes lideradas pela bioindústria regional, organizações comunitárias e centros e instituições de pesquisa (COSTA, W. M, 2007; MIGUEL, L.M, 2007).

Esses segmentos produtivos têm viabilizado o aproveitamento dos tradicionais e novos produtos regionais sob novas tecnologias e práticas aplicadas aos usos racionais dos recursos e a incorporação de P\&D vinculada aos centros de pesquisa regionais no desenvolvimento de novos bioprodutos. Além do mais, os novos circuitos de produção técnico-espaciais nessa região têm integrado subespaços entre os centros urbanos e seus municípios de influência, abrangendo áreas rurais tradicionais tipicamente vinculadas à pequena produção familiar, como no Nordeste Paraense, e às diversas comunidades ribeirinhas do Baixo e do Médio Amazonas/Solimões (COSTA, W. M, 2007. BECKER, B., 2009).

Os sistemas de produção em torno da fruticultura regional, óleos vegetais e essenciais têm incorporado novos componentes tecnológicos de cultivo baseados em sistemas agroflorestais e de processamento, incluindo também a sua integração a empreendimentos agroindustriais nacionais e internacionais de variados portes. Diversos produtos amazônicos têm demonstrado potencial de uso, como apresentado neste trabalho, entretanto alguns insumos se destacam no segmento da bioindústria de cosméticos, dentre eles, o açaí, o guaraná e a castanha (Tabela 11). 
Tabela 11 - Comercialização de Produtos Florestais Não-Madeireiros da Amazônia - 2006 (toneladas)

\begin{tabular}{|l|c|c|c|c|c|c|c|}
\hline \multicolumn{1}{|c|}{ Estados } & Açaí & Andiroba & Castanha & Cupuaçu & Guaraná & Tucumã & $\begin{array}{c}\text { Óleo de } \\
\text { Copaíba }\end{array}$ \\
\hline Acre & 356 & 4 & 3.280 & - & 2 & - & - \\
\hline Amapá & 936 & - & 1.045 & - & - & - & - \\
\hline Amazonas & 13.362 & 92 & 8.251 & - & 930 & 2.790 & 52 \\
\hline Maranhão & 7.897 & 318 & - & - & - & - & - \\
\hline $\begin{array}{l}\text { Mato- } \\
\text { Grosso }\end{array}$ & 2 & - & 435 & 5 & 79 & - & - \\
\hline Pará & 173.318 & 326 & 5.337 & 1.516 & 10 & 224 & 7 \\
\hline Rondônia & 115 & - & 424 & 109 & 95 & - & 1 \\
\hline Roraima & 394 & - & 876 & 1 & - & 24 & - \\
\hline Tocantins & 2 & - & - & 11 & - & - & - \\
\hline $\begin{array}{l}\text { Região } \\
\text { Norte }\end{array}$ & $\mathbf{1 8 8 . 4 8 1}$ & $\mathbf{4 2 2}$ & $\mathbf{1 9 . 2 1 3}$ & $\mathbf{2 . 4 0 8}$ & $\mathbf{1 . 0 3 7}$ & $\mathbf{3 . 0 3 8}$ & $\mathbf{6 0}$ \\
\hline $\begin{array}{l}\text { Brasil } \\
\text { (total) }\end{array}$ & $\mathbf{1 9 6 . 6 9 4}$ & $\mathbf{7 6 3}$ & $\mathbf{1 9 . 7 5 9}$ & $\mathbf{2 . 6 2 6}$ & $\mathbf{4 . 0 4 3}$ & $\mathbf{3 . 0 3 8}$ & $\mathbf{6 6}$ \\
\hline
\end{tabular}

Fonte: SIDRA/IBGE, 2012.

Exemplos de sistemas produtivos em expansão e consolidação na Amazônia são encontrados atualmente com a fruticultura, especialmente nos municípios de Tomé-Açu e Igarapé-Miri, no Pará, com a produção e o beneficiamento do açaí e de outras frutas liderado por pequenos produtores cooperados. Nesse caso, destacam-se a Cooperativa Agrícola Mista de ToméAçu (CAMTA) e também a Cooperativa Agroindustrial de Trabalhadores e Produtores Rurais de Igarapé-Miri (COOPFRUT) que estabelecem vínculos diversos com a agroindústria regional de sucos e concentrados.

Além desses, sobressaem os núcleos ribeirinhos em Rio Preto da Eva e os centros produtores de pequena a média escala em Maués e Presidente Figueiredo, localizados no estado do Amazonas, com a produção do guaraná e a intensa articulação dos locais de cultivo com as indústrias processadoras de extratos para a fabricação de refrigerantes e o atendimento dos mercados 
interno e de exportação. São muitos os impactos desses circuitos produtivos nas regiões em que se encontram instalados, sejam eles vinculados às escalas de produção e integração com os pequenos produtores familiares cooperados ou pela introdução de inovações tecnológicas nos sistemas de cultivo e do processamento das matérias-primas nos polos de extratos e refrigerantes em Manaus e municípios vizinhos, onde estão instaladas as maiores indústrias do setor, como a AMBEV (fabricante do Guaraná Antártica), em Maués, e da Coca Cola (Guaraná Kuat), em Presidente Figueiredo.

A castanha também é outro produto regional de grande destaque no mercado de cosméticos, mas diferentemente de outras matérias-primas que são cultivadas, as sementes são coletas em florestas localizadas principalmente em sub-regiões do Acre, Amazonas e Pará, que concentram juntos mais de $80 \%$ da produção (IBGE, 2006). Seu padrão de produção está basicamente circunscrito às reservas extrativistas ou áreas de coleta em núcleos isolados e normalmente integradas às unidades de beneficiamento de diversos produtores cooperados e extrativistas da região, sobretudo no estado do Acre, onde os locais de extração concentram-se nas sub-regiões do Purus e Baixo e Alto Acre e que se articulam com as usinas de beneficiamento em Xapurí e Brasiléia; como também no Sul Amazonense (municípios de Manicoré e Lábrea) e do Sudoeste Amazonense (municípios de Amatuá, Fonte Boa, Jutaí, Santo Antônio do Iça, dentre outros) (ADS, 2011; COOPERACRE, 2012).

Diante do quadro de aproveitamento dos produtos amazônicos, constata-se, desse modo, a integração de centenas de famílias a esses sistemas produtivos tradicionais, mas ao mesmo tempo inovadores por introduzirem ali novas bases técnicas de produção e agregação de valor (planos de manejo, certificação de origem das matérias-primas, pesquisa e 
melhoramento de espécies, etc.), qualidades cada vez mais exigidas no mercado de bioprodutos. Além disso, a articulação de diversas organizações comunitárias de pequenos produtores/extrativistas - em áreas isoladas ou próximas dos centros de processamento/industrialização nas capitais regionais - com diferentes agentes da cadeia produtiva da região e de fora dela também expressa as novas modalidades desses sistemas produtivos emergentes (COSTA, 2007; MIGUEL, L. M., 2007). Registre-se, ainda, que as iniciativas contam com apoio de alguns programas governamentais ${ }^{18}$ e os impactos positivos que os novos sistemas têm promovido para a qualidade de vida da população local.

\subsection{Principais Indústrias Internacionais na Produção de Biocosméticos}

$\mathrm{Na}$ produção de biocosméticos, o grupo das grandes indústrias transnacionais também aparece como líder desse estratégico segmento, desenvolvendo produtos com matérias-primas naturais e/ou orgânicas com diferentes tipos e quantidades de ativos. Essas linhas de produtos são normalmente altamente sofisticadas, diferenciadas e destinadas em sua maioria para um público específico do mercado consumidor mundial, disposto a pagar mais caro por produtos considerados menos agressivos ao corpo e também ao meio ambiente.

\footnotetext{
${ }^{18}$ Os sistemas produtivos comunitários têm recebido financiamento e apoio de diferentes agências de desenvolvimento e programas governamentais (Programa Nacional de Florestas; Bolsa Verde; projetos e subprogramas desenvolvidos pelo PP-G7, entre eles os Projetos Demonstrativos, do ProManejo e do ProVárzea (Projeto Manejo dos Recursos Naturais da Várzea).Dentre as ações, destacam-se o apoio para a organização comunitária em torno das etapas de cultivo e coleta dos produtos florestais não-madeireiros e das fases de beneficiamento com o aporte de infraestrutura, etc. (MMA, 2012).
} 
Atualmente, a grande indústria envolvida com o mercado de produtos naturais concentra cerca de $50 \%$ do total direcionado a esse segmento (Kline \& Company, 2011) e uma das características predominantes das multinacionais tem sido a aquisição de marcas menores e já consolidas no mercado dos biocosméticos. As fusões e aquisições no setor estão vinculadas a alguns condicionantes principais, conforme apontado por Morris (2009), por exemplo: expansão da rede de produção e de comercialização em mercados emergentes; redução de custos e sinergias; ampliação de novos modelos de canais de venda, visando atingir novos consumidores e novos nichos de mercado.

Dentre as principais indústrias, destacam-se a L'Oréal que adquiriu a inglesa The Body Shop (uma das pioneiras do segmento) em 2006, a indústria centenária estadunidense Kiehl's, em 2000, e a francesa Sanoflore, em 2006; a Estée Lauder que comprou as também estadunidenses Aveda em 1993, a Bumble and Bumble em 2000, a francesa Darphin em 2003 e, ainda, a indiana especializada em produtos baseados na medicina Ayurvedica utilizados em spas de luxo, a Forest Essentials em 2008; Além dessas, o grande grupo Colgate-Palmolive adquiriu a Tom's of Maine em 2006.

Outras estratégias das grandes indústrias também têm sido o lançamento de linhas próprias, como a Yves Rocher, a L'Occitane en Provence e, ainda, a Estée Lauder, que além das empresas adquiridas citadas logo acima, lançou a marca Origins (Quadro 6). 


\section{Quadro 6 - Panorama Atual das Principais Indústrias Mundiais no Segmento de Biocosméticos}

\begin{tabular}{|c|c|c|c|c|}
\hline $\begin{array}{c}\text { Empresa e } \\
\text { Origem }\end{array}$ & $\begin{array}{c}\text { Marcas de } \\
\text { Biocosméticos }\end{array}$ & $\begin{array}{c}\text { Origem } \\
\text { das Marcas } \\
\text { adquiridas }\end{array}$ & Produtos & $\begin{array}{l}\text { Mercados em } \\
\text { que atuam }\end{array}$ \\
\hline \multirow{3}{*}{$\begin{array}{l}\text { L’Oréal } \\
\text { (França) }\end{array}$} & The Body Shop & Reino Unido & $\begin{array}{l}\text { Maquiagem, } \\
\text { Perfumes, Cremes } \\
\text { para pele, Xampus, } \\
\text { Produtos Masculinos, } \\
\text { para corpo e banho, } \\
\text { etc. }\end{array}$ & $\begin{array}{l}\text { Diversos países da } \\
\text { Europa e Ásia; } \\
\text { EUA, Canadá e } \\
\text { Austrália. }\end{array}$ \\
\hline & Kiehl's & EUA & $\begin{array}{l}\text { Cremes para pele, } \\
\text { Produtos para o corpo, } \\
\text { cabelos e para o } \\
\text { público masculino. }\end{array}$ & $\begin{array}{l}\text { Em } 34 \text { países: } \\
\text { diversos países da } \\
\text { Europa e Ásia; } \\
\text { América do Norte; } \\
\text { Brasil, Argentina e } \\
\text { Austrália. }\end{array}$ \\
\hline & Sanoflore & França & $\begin{array}{l}\text { Cremes para pele, } \\
\text { cuidado para o corpo } \\
\text { e banho, óleos } \\
\text { essenciais, etc. }\end{array}$ & $\begin{array}{l}\text { Países na Europa } \\
\text { e Rússia. }\end{array}$ \\
\hline \multirow{4}{*}{$\begin{array}{l}\text { Estée Lauder } \\
\text { (EUA) }\end{array}$} & Origins & - & $\begin{array}{l}\text { Cremes para pele, } \\
\text { maquiagem, produtos } \\
\text { para o corpo e banho. }\end{array}$ & EUA e Canadá. \\
\hline & Aveda & EUA & $\begin{array}{l}\text { Cremes, Maquiagem, } \\
\text { Perfumes, Produtos } \\
\text { para cabelo, corpo e } \\
\text { masculinos. }\end{array}$ & $\begin{array}{l}\text { Em } 24 \text { países } \\
\text { (EUA, Canadá; } \\
\text { Países do Caribe, } \\
\text { Europa e Ásia; } \\
\text { Austrália). }\end{array}$ \\
\hline & $\begin{array}{c}\text { Forest } \\
\text { Essentials }\end{array}$ & Índia & $\begin{array}{l}\text { Cremes para pele, } \\
\text { Produtos para o corpo, } \\
\text { cabelos, óleos } \\
\text { essenciais e cuidados } \\
\text { para mãe e filhos. }\end{array}$ & $\begin{array}{l}\text { Spas de luxo na } \\
\text { Îndia. }\end{array}$ \\
\hline & $\begin{array}{l}\text { Bumble and } \\
\text { Bumble }\end{array}$ & EUA & $\begin{array}{l}\text { Diversos Produtos } \\
\text { para o cuidado dos } \\
\text { cabelos. }\end{array}$ & $\begin{array}{l}\text { Em } 26 \text { países } \\
\text { (EUA, Canadá, } \\
\text { países da Europa e } \\
\text { caribe; Cingapura; } \\
\text { Austrália e Nova } \\
\text { Zelândia). }\end{array}$ \\
\hline $\begin{array}{l}\text { Estée Lauder } \\
\text { (EUA) }\end{array}$ & Darphin & França & $\begin{array}{l}\text { Cremes para pele, } \\
\text { produtos para o corpo, } \\
\text { cremes dentais e } \\
\text { protetores solares. }\end{array}$ & $\begin{array}{l}\text { Em } 10 \text { países } \\
\text { (EUA, França, } \\
\text { Alemanha, Itália, } \\
\text { Espanha, Reino } \\
\text { Unido, Rússia, } \\
\text { Coréia do Sul e } \\
\text { Taiwan. }\end{array}$ \\
\hline $\begin{array}{l}\text { Johnson \& } \\
\text { Johnson } \\
\text { (EUA) }\end{array}$ & Aveeno & - & $\begin{array}{l}\text { Cremes para pele, } \\
\text { produtos para os } \\
\text { cabelos e corpo, } \\
\text { protetores solares e } \\
\text { produtos infantis. }\end{array}$ & EUA \\
\hline $\begin{array}{l}\text { Yves Rocher } \\
\text { (França) }\end{array}$ & Yves Rocher & - & $\begin{array}{l}\text { Perfumes, cremes } \\
\text { faciais, produtos para } \\
\text { corpo, banho e }\end{array}$ & $\begin{array}{l}\text { Em mais de } 50 \\
\text { países (América do } \\
\text { Norte, Europa, }\end{array}$ \\
\hline
\end{tabular}




\begin{tabular}{|l|l|l|l|l|}
\hline & & $\begin{array}{l}\text { cabelos, protetores } \\
\text { solares e produtos } \\
\text { para os homens. }\end{array}$ & $\begin{array}{l}\text { diversos países na } \\
\text { Ásia e África. }\end{array}$ \\
\hline $\begin{array}{l}\text { L'Occitane en } \\
\text { Provence } \\
\text { (França) }\end{array}$ & L'Occitane & - & $\begin{array}{l}\text { Perfumes, Cremes } \\
\text { para pele, produtos } \\
\text { para banho, cabelos e } \\
\text { para o público } \\
\text { masculino }\end{array}$ & $\begin{array}{l}\text { Em mais de 100 } \\
\text { países (países de } \\
\text { todos os } \\
\text { continentes). }\end{array}$ \\
\hline $\begin{array}{l}\text { Colgate- } \\
\text { Palmolive } \\
\text { (EUA) }\end{array}$ & Tom's of Maine & EUA & $\begin{array}{l}\text { Sabonetes, cremes } \\
\text { dentais, anti-sépticos } \\
\text { bucais, desodorantes, } \\
\text { etc. }\end{array}$ & $\begin{array}{l}\text { Principalmente } \\
\text { EUA. }\end{array}$ \\
\hline $\begin{array}{l}\text { The Clorox } \\
\text { Company } \\
\text { (EUA) }\end{array}$ & Burt's Bees & EUA & $\begin{array}{l}\text { Cremes para pele, } \\
\text { produtos para os } \\
\text { cabelos, maquiagem e } \\
\text { produtos infantis e } \\
\text { masculinos }\end{array}$ & $\begin{array}{l}\text { Suécia, Noruega, } \\
\text { Irlanda, Japão, } \\
\text { Coréia do Sul, } \\
\text { Taiwan, Hong } \\
\text { Kong, Tailândia, } \\
\text { Nova Zelândia, } \\
\text { Austrália }\end{array}$ \\
\hline $\begin{array}{l}\text { Shiseido } \\
\text { (Japão) }\end{array}$ & Bare Escentuals & EUA & $\begin{array}{l}\text { Cremes para pele e } \\
\text { maquiagens } \\
\text { (especializada em } \\
\text { ativos minerais) }\end{array}$ & $\begin{array}{l}\text { Principalmente } \\
\text { EUA. } \\
\text { Expansão para } \\
\text { novos mercados. }\end{array}$ \\
\hline
\end{tabular}

Fonte: Homepage das empresas. Elaborado pela Autora, 2011.

Esse grupo de indústrias desenvolve um amplo e diversificado conjunto de produtos - em sua maioria sofisticados - e que implicam em elevados investimentos em C\&T e capacidade inovadora, sejam esses desenvolvidos internamente pelas indústrias ou em parcerias com outros laboratórios e instituições de pesquisa de todo o mundo. Experiências internacionais representativas da tendência em inovações de produtos e processos industriais para cosméticos, bem como das novas regras de certificação do setor podem ser destacadas em um grupo de indústrias francesas que desenvolvem diversas linhas de produtos naturais, inclusive com algumas matérias-primas da biodiversidade amazônica. 


\subsubsection{Experiências Pioneiras do Segmento: os biocosméticos em Provence-Alpes-Cotê D'Azur, França}

De acordo com os dados de 2009 disponíveis no Instituto Nacional de Estatística e Estudos Econômicos da França (INSEE), existiam no país novecentas e noventa e quatro indústrias ${ }^{19}$ que atuavam no mercado de produtos de higiene pessoal, perfumaria e cosméticos, representando um faturamento total em torno de $€ 12$ bilhões (incluindo sabões e produtos de limpeza, mas excluindo óleos essenciais e resinóides). Com exceção da indústria bélica, estudos apontam o setor de cosméticos francês como 0 quarto maior setor industrial do país, antecedido pelas indústrias de bebidas, automobilística e aeroespacial, respectivamente (MORETTI, C.; AUBERTIN, C., 2008). Este quadro exemplifica a importância e a participação desse ramo industrial no conjunto da economia francesa.

Os produtos de beleza, maquiagem e cuidados da pele, incluindo protetores solares, formam o maior grupo de produtos desenvolvidos nas indústrias da França, bem como as de maior faturamento. Na fabricação de óleos, as indústrias produtoras de aromáticos naturais e óleos essenciais também totalizam as vendas desse subsetor e em seguida as indústrias processadoras de misturas odoríferas e resinóides (INSEE, 2009).

Os indicadores do comércio internacional de óleos essenciais, cosméticos, perfumes e produtos de higiene pessoal do setor indicam a França como o maior exportador de bens finais em todo o mundo. Em 2009, esse comércio envolveu US $\$ 13,6$ bilhões, o que representou 16\% das exportações mundiais, sendo os países da União Europeia, os principais destinos da

\footnotetext{
${ }^{19}$ Nesta consulta, foram consideradas apenas as empresas com 20 ou mais assalariados.
} 
produção francesa, com destaque excepcional para o mercado alemão, onde foram movimentados quase US\$ 2 bilhões, representando 13,8\% das relações comerciais da França nesse setor industrial.

Já os dados mais recentes sobre o estratégico mercado de biocosméticos demonstram que esse segmento também está em plena expansão na França, que por sua vez registra as maiores taxas de crescimento dentre os demais países europeus. Nos últimos anos, esse segmento expandiu 50\% apenas na França (Gráfico 21) e mesmo que ainda não represente elevada participação nas vendas totais do setor, estimativas indicam que 0 mercado de biocosméticos poderá concentrar um terço do total de cosméticos consumidos nesse país em 2012/2013 (MULON, L., 2010).

\section{Gráfico 21 - Evolução do Mercado dos biocosméticos na França entre 2006 e 2009}

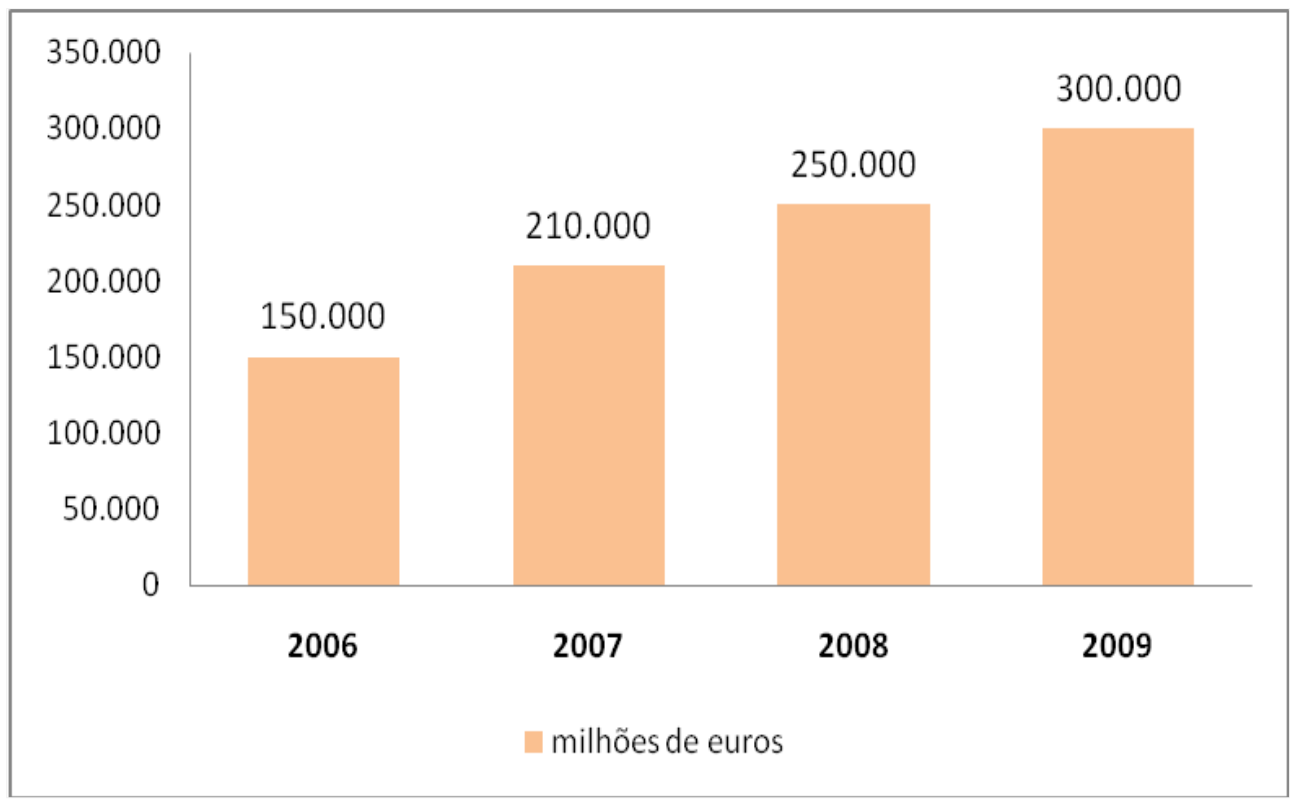

Fonte: MULON, L., 2010. Elaborado pela Autora.

Os produtos de cuidado da pele, como cremes para o corpo e máscaras faciais lideram o segmento de produtos naturais e juntos representam mais de $80 \%$ dos lançamentos nessa área, totalizando mais de $€ 110$ milhões de 
faturamento na França em 2007. Em seguida, os produtos de higiene pessoal e capilares, especialmente xampus e condicionadores, registram o segundo e terceiro maior faturamento, no entanto os subsegmentos de maquiagem e perfumaria ainda não têm demonstrado significativos volumes se comparados com as tendências em curso para os demais tipos de produtos naturais (Gráfico 22).

\section{Gráfico 22 - Distribuição do Segmento de Biocosméticos na França em 2007}

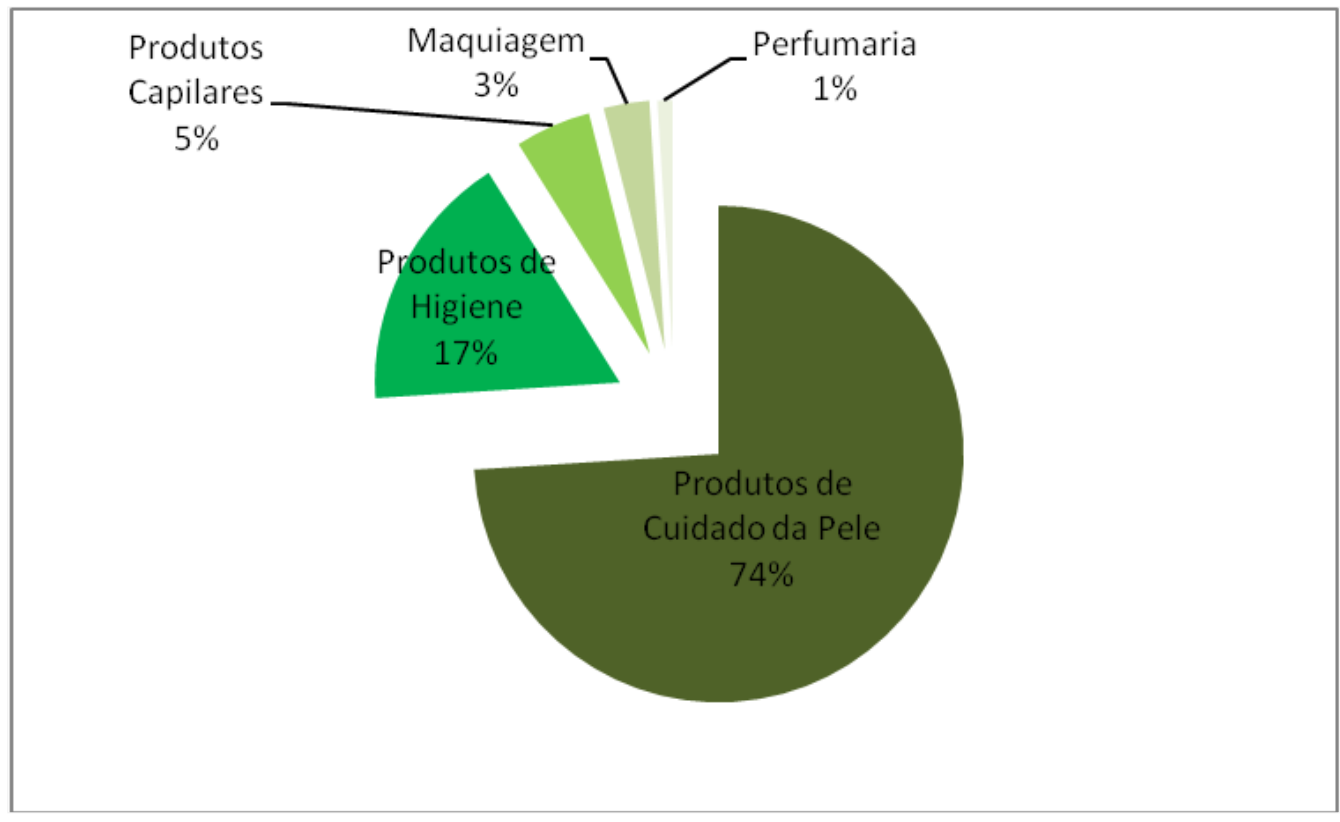

Fonte: BAURES, C. et al., 2009. Elaborado pela Autora.

Estudos da OCDE (2011) apontam que as empresas privadas são atualmente os principais agentes responsáveis pelas atividades de P\&D na França, diferentemente do que acontece em outros países, como no Brasil, onde a maior parcela dessas atividades ainda está vinculada aos investimentos do governo. Em 2008, a indústria química francesa, da qual faz parte o setor de cosméticos, investiu cerca de $€ 1,5$ bilhões em P\&D, representando $6,4 \%$ dos investimentos aplicados em todo o setor industrial do país (INSEE, 2009). Os componentes naturais têm sido um dos principais focos da pesquisa e inovação 
da indústria nesse país, com destaque para os produtos de cuidado com a pele, cabelo e banho.

As empresas de cosméticos na França concentram-se na sua maioria em polos regionais, conhecidos no país como polos de competitividade, formados por indústrias, laboratórios, universidades, centros e institutos de pesquisa que visam, principalmente, centralizar um conjunto de diversos mecanismos de desenvolvimento da sua estrutura produtiva, de cooperação, financiamentos e incentivos à ciência, tecnologia e inovação, etc. No caso dos cosméticos, eles são identificados especialmente em dois polos, o Cosmetic Valley (o maior deles, na região central) e o polo PASS (Pôle de Compétitivité Parfums, Arômes, Senteurs, Saveurs), que será detalhado mais adiante. Além desses, destaca-se o polo Trimatec, que apesar de não se dedicar exclusivamente ao setor, desenvolve pesquisas na área da nanotecnologia, com foco na extração de moléculas de plantas para o uso nas indústrias de alimentos, fármacos e cosméticos.

O panorama industrial no segmento dos bioprodutos indica que diversas empresas desenvolvem produtos com pequenas quantidades de ativos naturais, sobretudo como estratégia de mercado. Dentre o grupo de grandes empresas mais representativas do setor, destacam-se a L'Occitane e a Yves Rocher, que apresentam diversas linhas com matérias-primas naturais e produtos sofisticados e diferenciados destinados majoritariamente para um público específico do mercado consumidor. Há que se destacar também a gigante L'Oreal, que como apresentado anteriormente, adquiriu outras empresas vinculadas especificamente ao segmento de produtos naturais, como a The Body Shop, Kiehl's e a Sanoflore. Além dessas, outras empresas 
francesas de menor porte, como a Melvita, Phyt's, Léa Nature, Florame e Cattier, também formam o grupo das indústrias produtoras de biocosméticos.

A fim de ilustrar alguns dos principais sistemas produtivos dos cosméticos naturais na França, apresentamos a seguir os exemplos mais representativos que se desenvolvem atualmente na região de Provence-AlpesCôte d'Azur, localizada no sul do país. As informações aqui reunidas foram obtidas a partir de um conjunto de dados e materiais sobre o tema, bem como de trabalhos de campo realizados nessa região, que envolveram visitas técnicas e entrevistas com dirigentes de um grupo de produtores, centros de pesquisa e de desenvolvimento tecnológico.

Provence-Alpes-Côte d'Azur (PACA) é tradicionalmente conhecida como a região da França que concentra as plantas aromáticas e medicinais. Ela detém uma extensa variedade de plantações de espécies que são utilizadas em diferentes segmentos industriais, sendo reconhecidas especialmente as "herbes de Provence" (ervas aromáticas) e os extensos campos de lavandas. Como dito anteriormente, a lavanda e o lavandin configuram o grupo de plantas com destaque nos diversos produtos da indústria de cosméticos, perfumaria e de higiene pessoal, daí o interesse e foco especial no estudo dessas espécies (Figura 5).

Os óleos de lavanda são utilizados na produção de cosméticos, perfumes finos, medicamentos e na aromaterapia, e o lavandin, variedade híbrida do cruzamento da lavanda fina e da lavanda aspic, é destinado em sua maioria (90\%) para a fabricação de sabonetes, amaciantes e detergentes (CIHEF, 2008). As culturas de lavanda e lavandin abrangem uma área de 12 mil hectares (ha) na região de PACA, sendo que a produção de lavanda representa $70 \%$ das áreas de cultivo desta espécie no país e equivale a $86 \%$ 
da produção nacional. O cultivo de lavanda rende cerca de $15 \mathrm{~kg} / \mathrm{ha}$ de óleo essencial, e o lavandin chega a produzir 100kg/ha. Por apresentar maior resistência e rendimento, as plantações de lavandin se multiplicaram para atender a demanda das grandes indústrias e, além disso, a expansão da produção em países concorrentes nas últimas décadas, como Bulgária e China, também impulsionaram as áreas de cultivo dessa variedade na França.

\section{Figura 5 - Cultura de Lavanda em Provence-Alpes-Côte d'Azur}

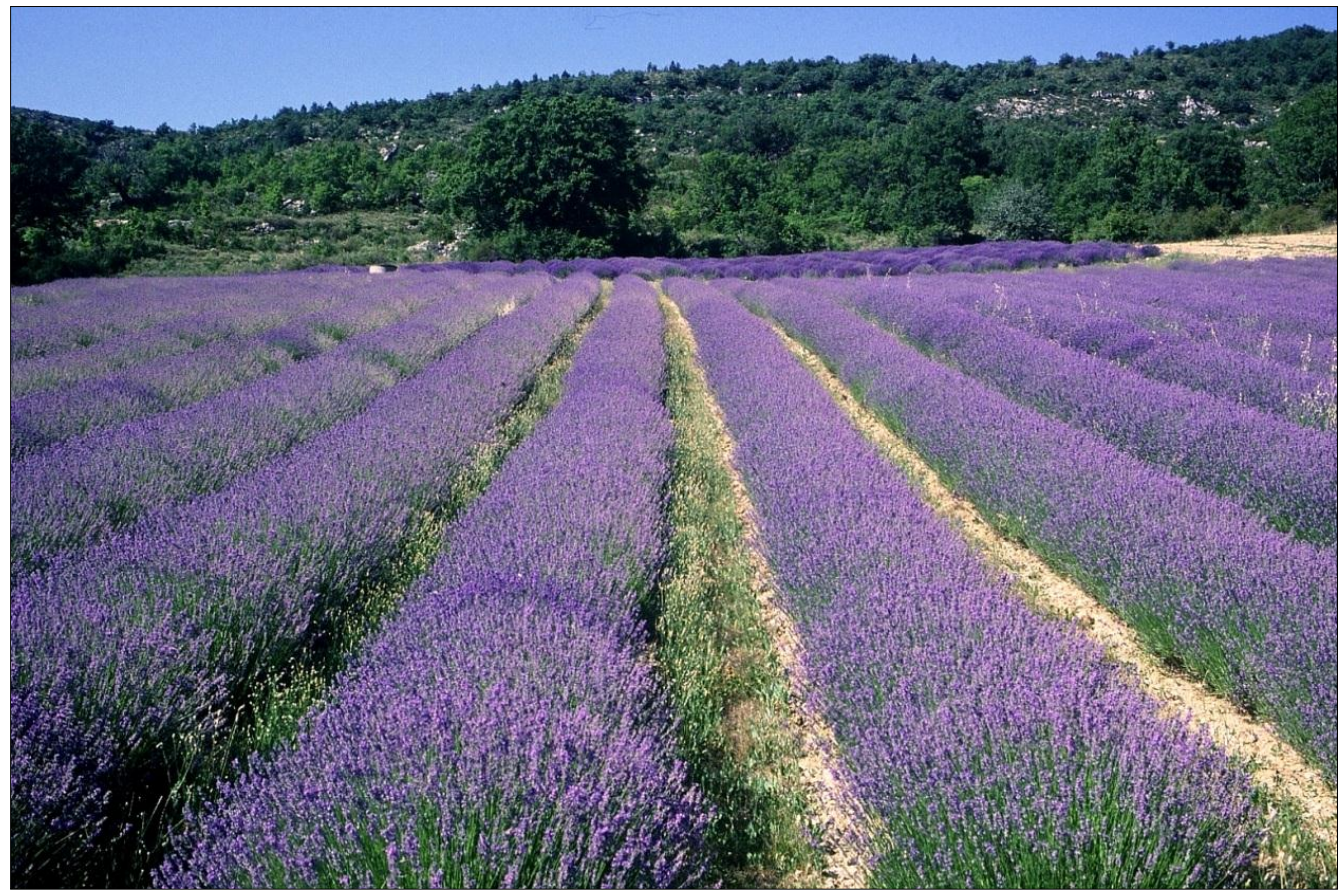

Foto: Registro da Autora em trabalho de campo, Manosque, França, 2010.

Apesar do crescimento da produção, atualmente alguns problemas de influência climática e pragas têm provocado o decréscimo das áreas de cultivo dessas plantas e dos demais variados tipos de espécies aromáticas da região, como observado na Tabela 12, a seguir (AGRESTE, 2010). 


\section{Tabela 12 - Produção de Lavanda e Lavandin em}

Provence-Alpes-Côte d'Azur em 2009

\begin{tabular}{c|c|c|c}
\hline \multirow{2}{*}{$\begin{array}{c}\text { Produção de Lavanda e } \\
\text { Lavandin em hectares e } \\
\text { toneladas }\end{array}$} & $\mathbf{2 0 0 9}$ & $\mathbf{2 0 0 9 / 2 0 0 8}$ & $\begin{array}{c}\text { 2009/média entre } \\
\mathbf{2 0 0 4 - 2 0 0 8}\end{array}$ \\
\cline { 2 - 4 } & 2.500 & $-1,8 \%$ & $-17,3 \%$ \\
\hline Área cultivada de lavanda (ha) & 41 & $2,1 \%$ & $6,3 \%$ \\
\hline Produção de lavanda (ton) & 9.440 & $-0,6 \%$ & $-1,2 \%$ \\
\hline Área cultivada de lavandin (ha) & 731 & $5,8 \%$ & $11,8 \%$ \\
\hline Produção de lavandin (ton) & & & \\
\hline
\end{tabular}

Fonte: AGRESTE, 2010.

Nessa região, as produções de lavanda e lavandin envolvem mais de três mil pequenos produtores, muitos deles agrupados em cooperativas, gerando cerca de 25 mil empregos indiretos nesse circuito produtivo. Visando o aumento da produtividade, melhoramento genético e a redução de custos, entre outros, os centros e institutos de pesquisa instalados na região trabalham em parceria com as cooperativas e oferecem assistência técnica para os pequenos produtores, com destaque para o CRIEPPAM (Centre Régionalisé Interprofessionnel d'Expérimentation en Plantes à Parfum).

Outro aspecto desse circuito está relacionado à concorrência da enorme produção das variedades sintéticas desenvolvidas pela Bulgária e China. Em resposta, a França tem expandido o cultivo do lavandin, mas em contrapartida também tem investido na mudança de seus sistemas produtivos com a introdução de matérias-primas orgânicas. Segundo a ONIPPAM (2007), existem mais de três mil hectares de culturas orgânicas e 1.882 produtores envolvidos nesses sistemas produtivos em seis das vinte e seis regiões administrativas da França, incluindo a região de Provence-Alpes-Côte d'Azur. Do total de áreas cultivadas, $62 \%$ são destinadas às produções de lavanda e lavandin, e ressalte-se que a região de Provence concentra a maior parte das 
plantações dessas espécies. O cultivo da lavanda orgânica sempre superou 0 de lavandin, mas excepcionalmente no último inventário de 2007, a cultura da espécie híbrida excedeu as áreas de plantações da tradicional lavanda (Gráfico 23).

\section{Gráfico 23 - Culturas Orgânicas de Plantas Aromáticas e Medicinais na França* em 2007 (hectares)}

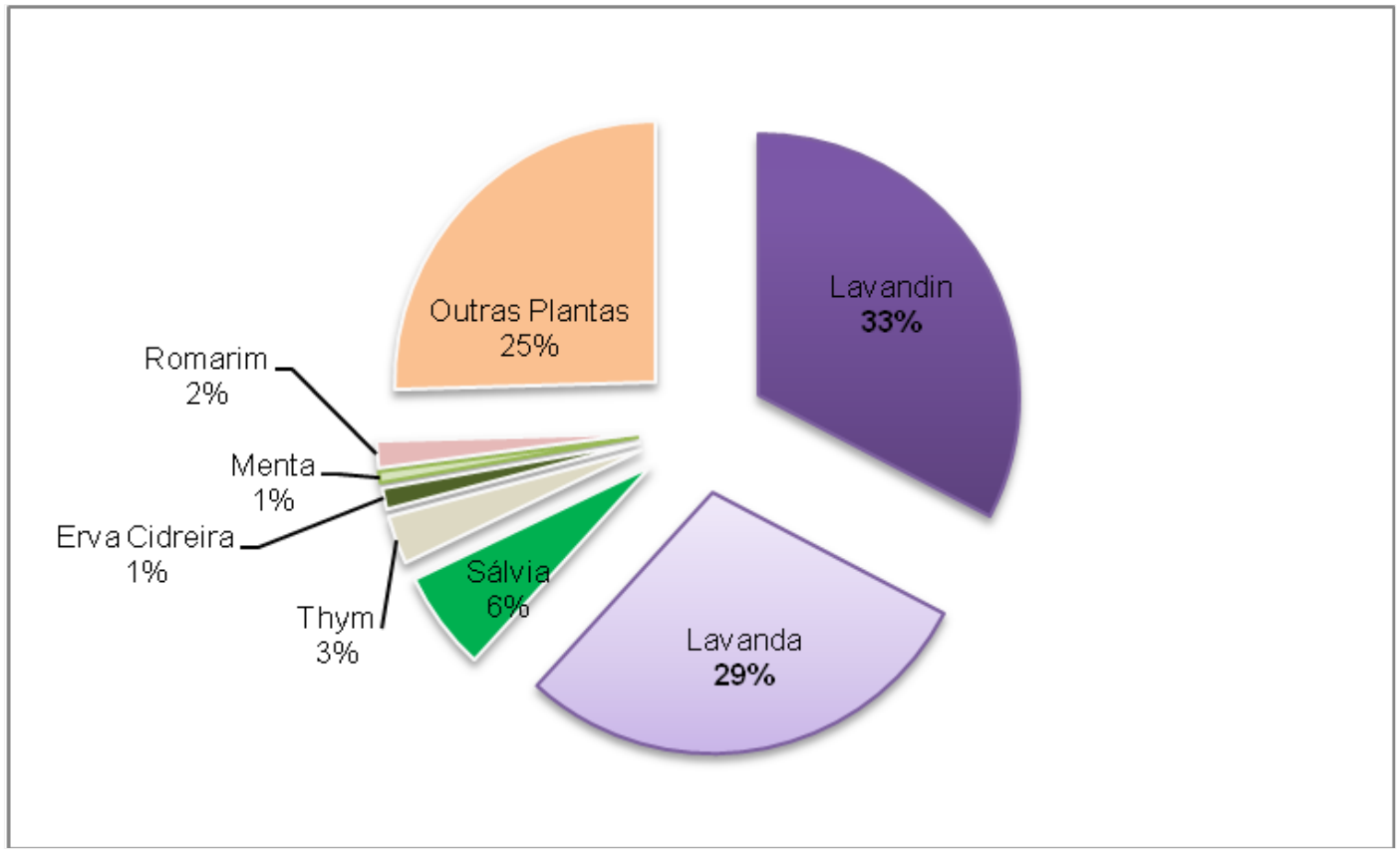

Fonte: ONIPPAM, 2007. * Foram consideradas apenas 6 regiões do país. Elaborado pela Autora.

O quadro atual de crescimento das áreas de cultivos orgânicos traduz as novas tendências do mercado quanto ao desenvolvimento de produtos contendo ingredientes naturais. Outro diferencial do setor tem sido a utilização dos mecanismos de certificação e a crescente regulação em torno do controle de qualidade dos produtos e, neste contexto, a região é uma das pioneiras na criação de selos de controle de origem das matérias-primas. Criado em 1981, o selo AOC (Appellation d'Origine Contrôlée) atesta a produção de lavanda, bem como de outras espécies, estabelecendo normas de alto padrão e rigor de análises físico-químicas dos componentes dos óleos essenciais e assegurando produtos de alta qualidade. Incorporando o nome da região (o terroir), os óleos 
de lavanda certificados são mais caros que as espécies desenvolvidas pelos demais países (Bulgária, China e Ucrânia), mas por outro lado são mais valorizados no mercado internacional e têm desse modo condições de disputar os principais nichos dos mercados importadores de fragrâncias.

Dentre as grandes empresas representativas no segmento dos produtos naturais instaladas na região, destaca-se a L'Occitane en Provence (Figura 6), que desenvolve uma extensa gama de produtos inovadores e sofisticados e tendo como foco principal o desenvolvimento de cremes faciais e corporais, xampus, condicionadores, sabonetes, óleos, perfumes femininos e masculinos e produtos aromatizantes para ambientes.

\section{Figura 6 - Fábrica da L'Occitane na região de Provence-Alpes-Côte d'Azur}

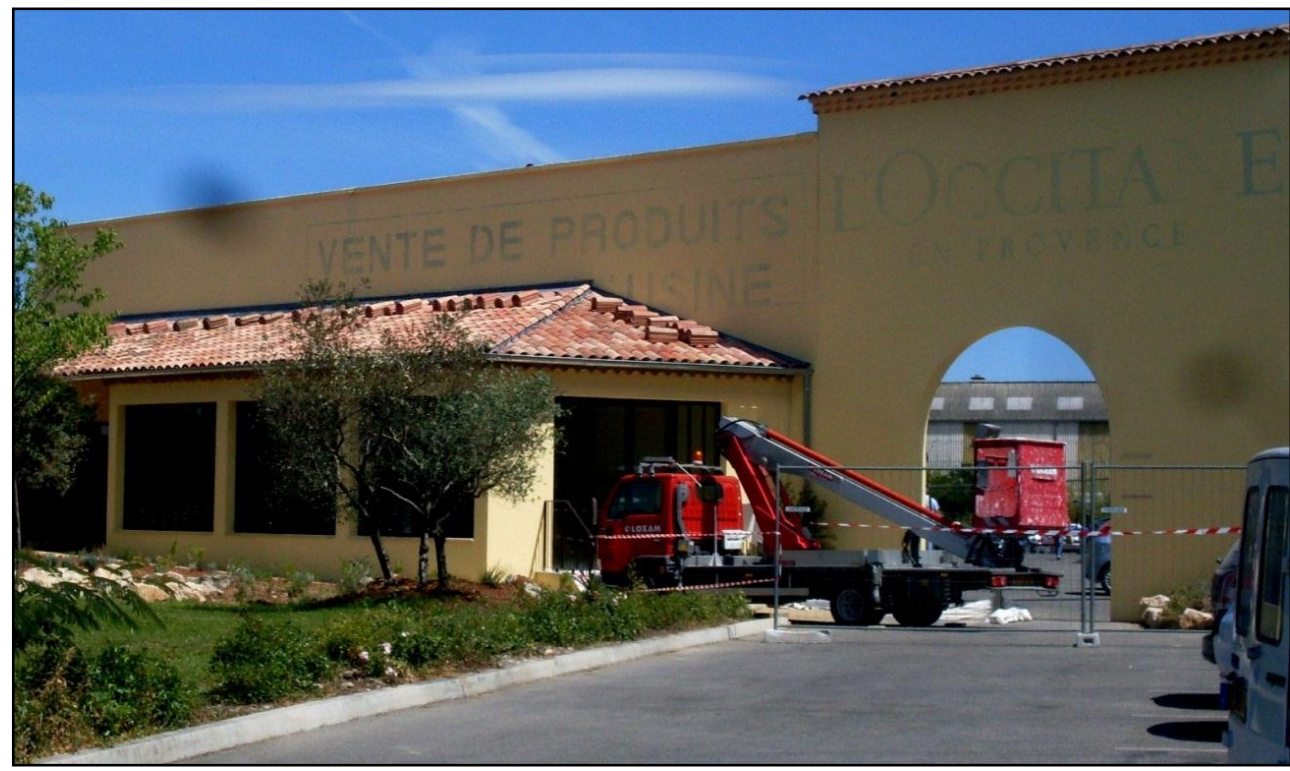

Foto: Registro da Autora em trabalho de campo, Manosque, França, 2010.

Fundada em 1976, a empresa tem sua principal unidade de produção instalada em Manosque e o mais importante destino das vendas de seus produtos tem sido o mercado asiático, seguido pelo europeu e o americano. As matérias-primas, especialmente o óleo essencial de lavanda certificada com o selo $A O C$, são pré-processadas nas pequenas destilarias e fornecidas pelas 
cooperativas da região. Segundo a empresa, $100 \%$ da lavanda utilizada em seus produtos advêm de matéria-prima orgânica.

De acordo com a EUROSTAT (2011), a L'Occitane ocupa o décimo quarto lugar no ranking mundial das empresas que se dedicam exclusivamente ao desenvolvimento de cosméticos e perfumes. Atualmente tem mais de mil pontos de vendas em cem países, dentre eles o Brasil, e unidades de tratamento de spa, em Paris, Hong-Kong e São Paulo e, registre-se que, desde 1995, a empresa atua no Brasil com franquias e unidades próprias, distribuídas em quarenta e três lojas, três spas e mais de duzentos e cinquenta pontos de venda em quinze estados e distrito federal. No início de 2008, a empresa lançou a primeira linha de produtos com fabricação desenvolvida em outro país, a "Linha Brasil", elaborada com matérias-primas da Amazônia e envolvendo comunidades tradicionais da região.

Os produtos dessa linha utilizam insumos do cupuaçu, buriti e da castanha e toda a cadeia produtiva é certificada e os produtos classificados como totalmente orgânicos. Essa nova linha foi lançada a partir da parceria com a Beraca, empresa responsável pelas etapas de extração e beneficiamento das matérias-primas regionais e pela capacitação e treinamento das populações locais envolvidas nesses processos. Dentre as comunidades que participam da cadeia produtiva, encontram-se pequenos produtores no município de Igarapé-Mirim, no Pará, com a coleta e extração do óleo de buriti; e na llha de Marajó, que participam do beneficiamento do óleo da castanha para a elaboração de protetores solares.

Sendo o setor de cosmético extremamente dinâmico e dependente do lançamento constante de produtos inovadores, as atividades de P\&D da empresa são intensas e realizadas por ela própria ou em parceria com 
universidades, centros e laboratórios especializados. Atualmente estão sendo estudadas cerca de 150 novas fórmulas e ingredientes para o desenvolvimento de novos produtos. Na empresa, os cremes faciais representam o grupo dos produtos com maiores investimentos de P\&D e inovação, concentrando também as patentes. Registre-se que a L'Occitane integra o grupo das indústrias do Polo de Competitividade PASS e dessa forma também conta com incentivos e apoio técnico.

Criado em 2005, o Polo de Cosméticos PASS (Pôle de Compétitivité Parfums, Arômes, Senteurs, Saveurs) concentra suas atividades em torno do circuito produtivo de 80 espécies de plantas aromáticas e medicinais cultivadas na "zona" no Polo (Mapa 4), com destaque para a lavanda e o lavandin, que representam quase $90 \%$ de suas áreas de cultivo. O Polo reúne centenas de representantes de toda a cadeia produtiva, desde produtores de matériasprimas e insumos, como de produtos acabados. Indústrias de diferentes áreas estão instaladas no Polo e não apenas aquelas envolvidas exclusivamente com o setor de cosméticos e perfumaria, como as indústrias de alimentos e medicamentos, sendo desenvolvidas pesquisas em diversos níveis, englobando tanto as matérias-primas naturais, como também os materiais industrializados e sintéticos. 


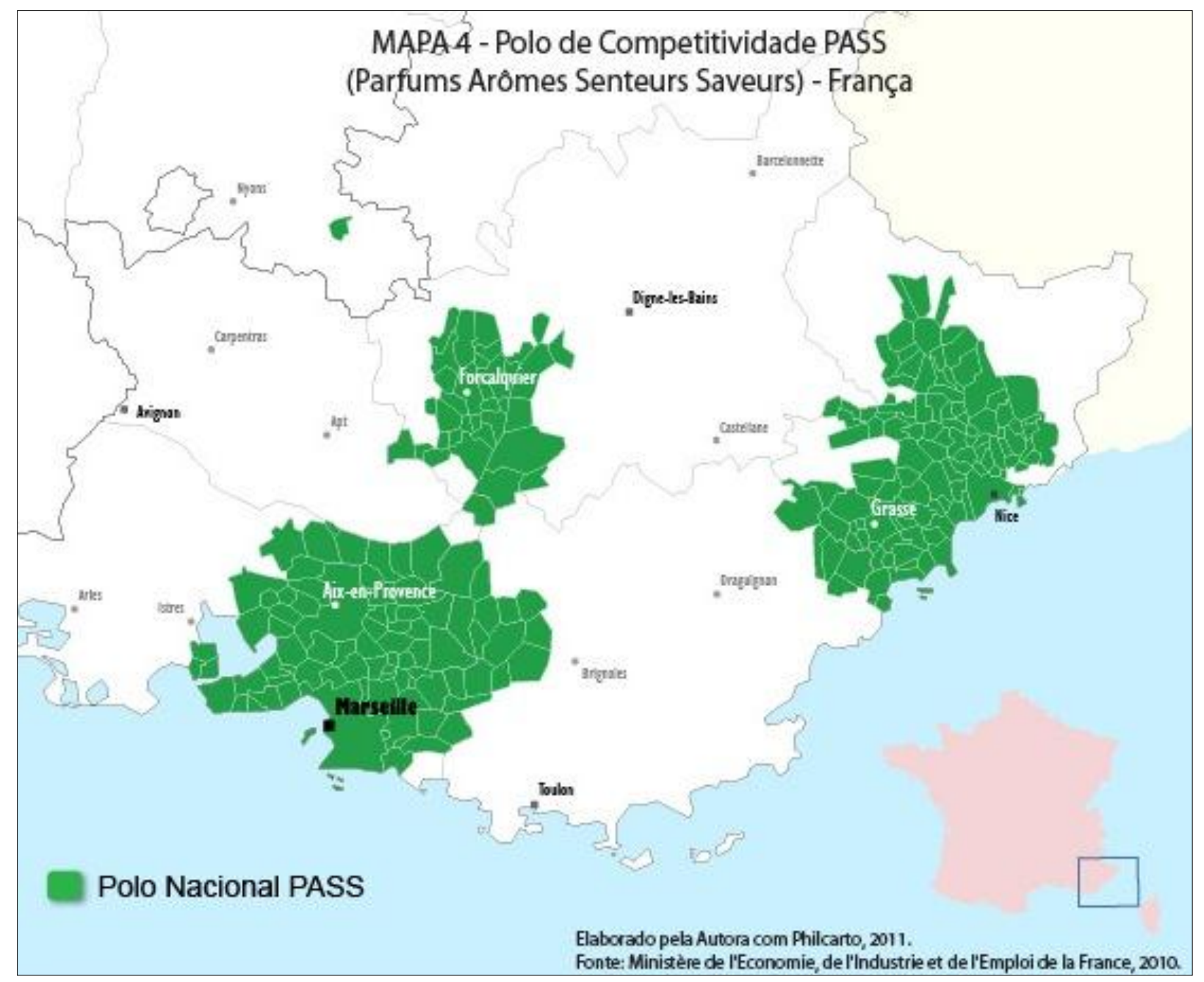

O PASS integra atualmente quinhentas e cinquenta empresas e uma rede especializada em pesquisa com trinta e dois laboratórios, que asseguram mais de $50 \%$ da produção nacional dos ingredientes (aromas, óleos, essências e fragrâncias) utilizados em cosméticos e perfumes. O faturamento do Polo gira em torno dos $€ 3$ bilhões anuais, equivalendo a $8 \%$ do total desses tipos de ativos vegetais em todo o mundo, sendo $70 \%$ da sua produção voltada para exportação. Sua associação representativa é formada por sindicatos mais de uma centena de membros das indústrias, dos quais noventa e sete são de pequenas e médias empresas. Além disso, o PASS concentra a maior parte das destilarias do país e envolve mais de três mil produtores de plantas aromáticas que movimentam mais de $€ 40$ milhões por ano (Mapa 5). 


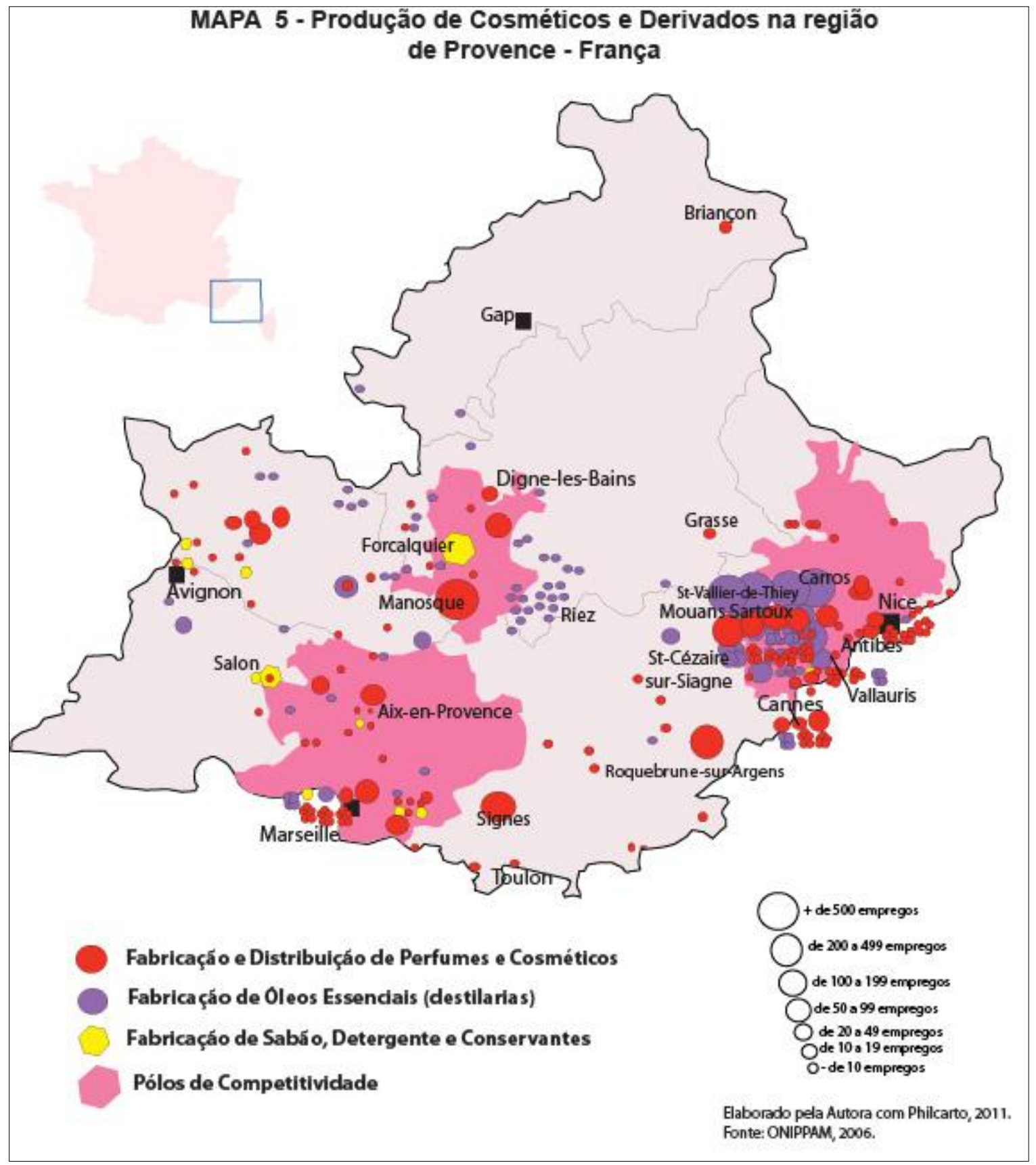

O Polo centraliza seus esforços nas atividades de P\&D, sobretudo nas pesquisas sobre extratos naturais da biodiversidade regional, incluindo um grande projeto de estudos das plantas da região do Mediterrâneo em colaboração com outros países. Visando atrair e promover os sistemas de pesquisa e inovação, bem como, da competitividade do setor, o PASS recebe diversos incentivos e financiamentos do governo francês, favorecendo assim a formação de redes de parcerias consolidadas entre os diversos atores da cadeia produtiva desta região. 


\subsection{Biocosméticos no Brasil}

Com um crescimento de mais de $10 \%$ nos últimos quinze anos e ocupando atualmente o terceiro lugar no ranking mundial, o mercado de consumo de produtos de cuidado pessoal, perfumaria e cosméticos no Brasil foi estimado em quase $\mathrm{R} \$ 60$ bilhões em 2010 (ABHIPEC, 2011). Esses dados incluem todos os tipos de produtos do setor, sem distinguir aqueles produtos denominados de naturais e/ou orgânicos. Segundo a empresa de consultoria Kline \& Company (2011), em 2010, o mercado brasileiro de cosméticos baseados em ativos naturais envolveu um total de $R \$ 7,5$ milhões, alcançando um crescimento de mais de $20 \%$ desde 2005 (Gráfico 24).

\section{Gráfico 24 - Evolução do Segmento de Biocosméticos no Brasil entre 2005 e 2010 (milhões de R\$)}

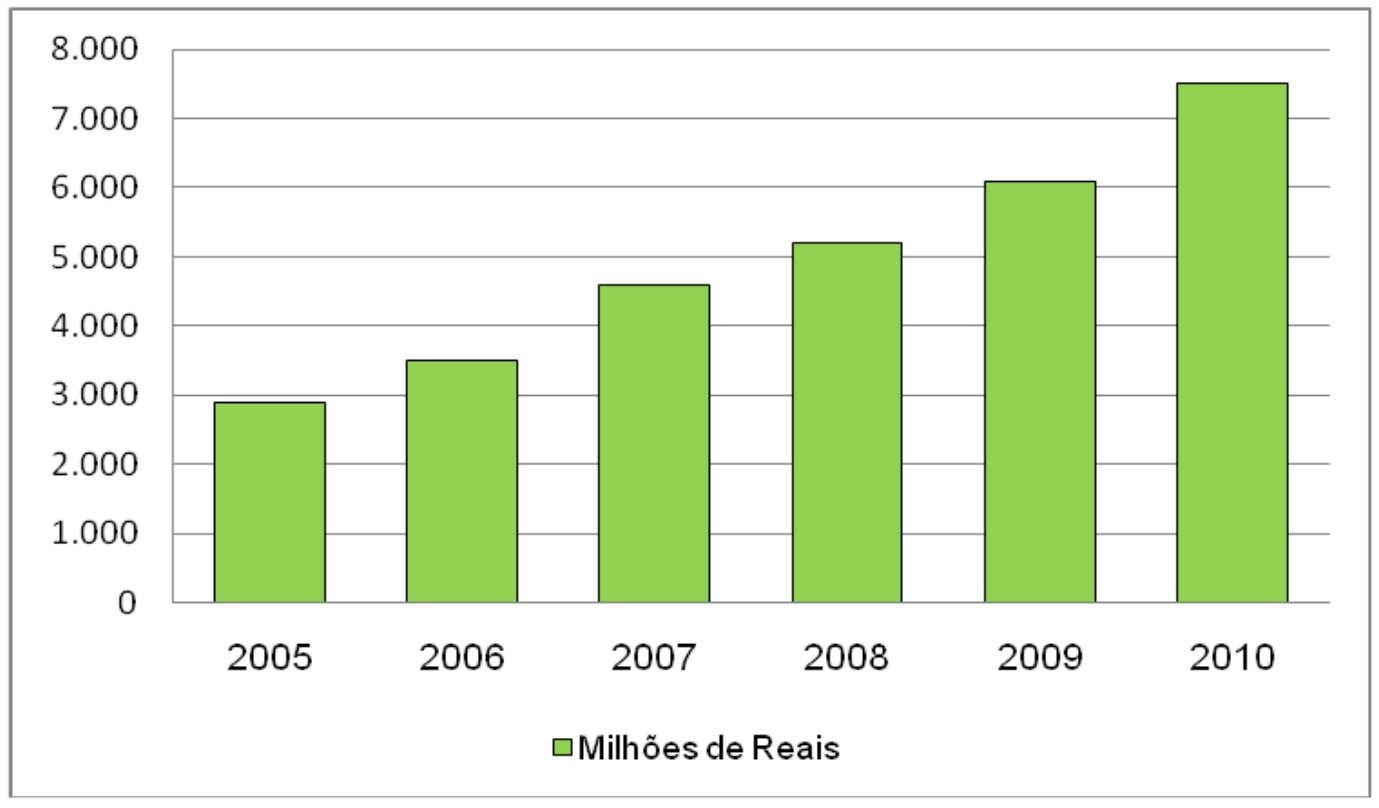

Fonte: Kline \& Company, 2011. Elaborado pela Autora.

Da mesma forma que os países europeus, os EUA e alguns países asiáticos, com destaque para a China, Índia e Coréia do Sul, o consumo para esses tipos de produtos tem ganhado cada vez mais adeptos no Brasil. A 
participação dos produtos naturais pode ser ainda discreta se comparada ao volume total de consumo da indústria de cosméticos em geral, no entanto, como o segmento contava até recentemente com pouquíssimas empresas especializadas, as estimativas atendem as perspectivas favoráveis de crescimento dessa nova tendência de mercado. A promissora liderança na expansão desse segmento no Brasil está vinculada a quatro fatores principais:

- O crescimento do uso de ingredientes desenvolvidos a partir da biodiversidade, sobretudo dos ativos vegetais da Amazônia brasileira;

- A crescente entrada de empresas nacionais nesse segmento de mercado, incorporando os produtos naturais aos seus portfólios;

- A falta de uma legislação nacional e específica que regulamente os biocosméticos interfere e prejudica a definição do segmento, mas consequentemente permite que muitas empresas divulguem seus produtos como sendo naturais, sem na verdade os serem, ou seja, como não existe atualmente um consenso oficial do que se poderia chamar de cosmético natural torna-se ainda mais difícil enquadrá-los em categorias com limites bem estabelecidos e, assim, as empresas utilizam o "slogan" e o "apelo" do natural para promover e diferenciar seus itens nesse competitivo mercado;

- A Natura, líder do mercado nacional, tem focado há pelo menos uma década a produção de linhas com ativos da biodiversidade (o maior exemplo é o da linha Ekos) e através de fortes campanhas de marketing tem conquistado cada vez mais espaço, alcançado amplamente o mercado consumidor em todo o país. 
Em um cenário de intensa competição internacional, os esforços em pesquisa científica e inovação tecnológica e, mais precisamente, a capacidade de transformar conhecimentos em processos e produtos industriais valorizados, colocam um desafio para as indústrias nacionais na disputa de mercado com as grandes empresas líderes internacionais.

A fim de ilustrar os aspectos do segmento industrial dos biocosméticos em curso no Brasil e as diversas expressões da sua territorialização, apresentamos a seguir os exemplos mais representativos de um grupo de indústrias localizadas, sobretudo, no estado de São Paulo e na Amazônia Brasileira. A partir do levantamento de documentos e relatórios técnicos específicos do segmento e das informações primárias obtidas nas entrevistas e visitas a um grupo de empresas, traçamos um panorama atual dos principais processos produtivos de algumas indústrias nacionais que se dedicam ao desenvolvimento de cosméticos baseados em ativos da biodiversidade. Tendo em vista que esse segmento industrial é extremamente competitivo, sobretudo no tocante ao estratégico mercado dos biocosméticos, não podemos deixar de registrar a dificuldade encontrada para executar esta pesquisa. Segundo as empresas analisadas, os dados internos são considerados sigilosos e, dessa forma, encontramos bastante dificuldade para obter determinadas informações devido às questões de confidencialidade. Além disso, destaque-se, a propósito, que a maior parte delas nem permitiu que fossem realizadas as visitas técnicas e entrevistas com os dirigentes e/ou técnicos responsáveis.

A entrada da indústria brasileira no segmento de biocosméticos também tem sido uma das estratégias para a sua inserção no mercado internacional. Essa tendência tem se traduzido em oportunidades para as indústrias que desenvolvem produtos finais, como também para as intermediárias e 
processadoras de matérias-primas e insumos dessa cadeia produtiva. $O$ aproveitamento da biodiversidade brasileira na formulação dos produtos tem forte identidade e potencial nesse mercado mundial e os biocosméticos, especialmente aqueles com princípios ativos da flora amazônica, têm excepcional apelo na opinião pública internacional, sobretudo quando esses são relacionados à utilização dos recursos naturais da região segundo os critérios da sustentabilidade ambiental e social, repercutindo diretamente na valorização dos mesmos. Nesse panorama, registre-se um pequeno grupo de empresas brasileiras que destina quase a totalidade de seus produtos para outros países que já apresentam um mercado consumidor completamente consolidado.

No mercado de biocosméticos do Brasil, a Natura também lidera esse estratégico segmento frente às demais empresas, seguida pelo $\mathrm{O}$ Boticário, o grupo Granado Pharmácias, Nasha e Farmaervas (Gráfico 25).

Gráfico 25 - Indústrias* Líderes no Mercado de Biocosméticos no Brasil em 2010

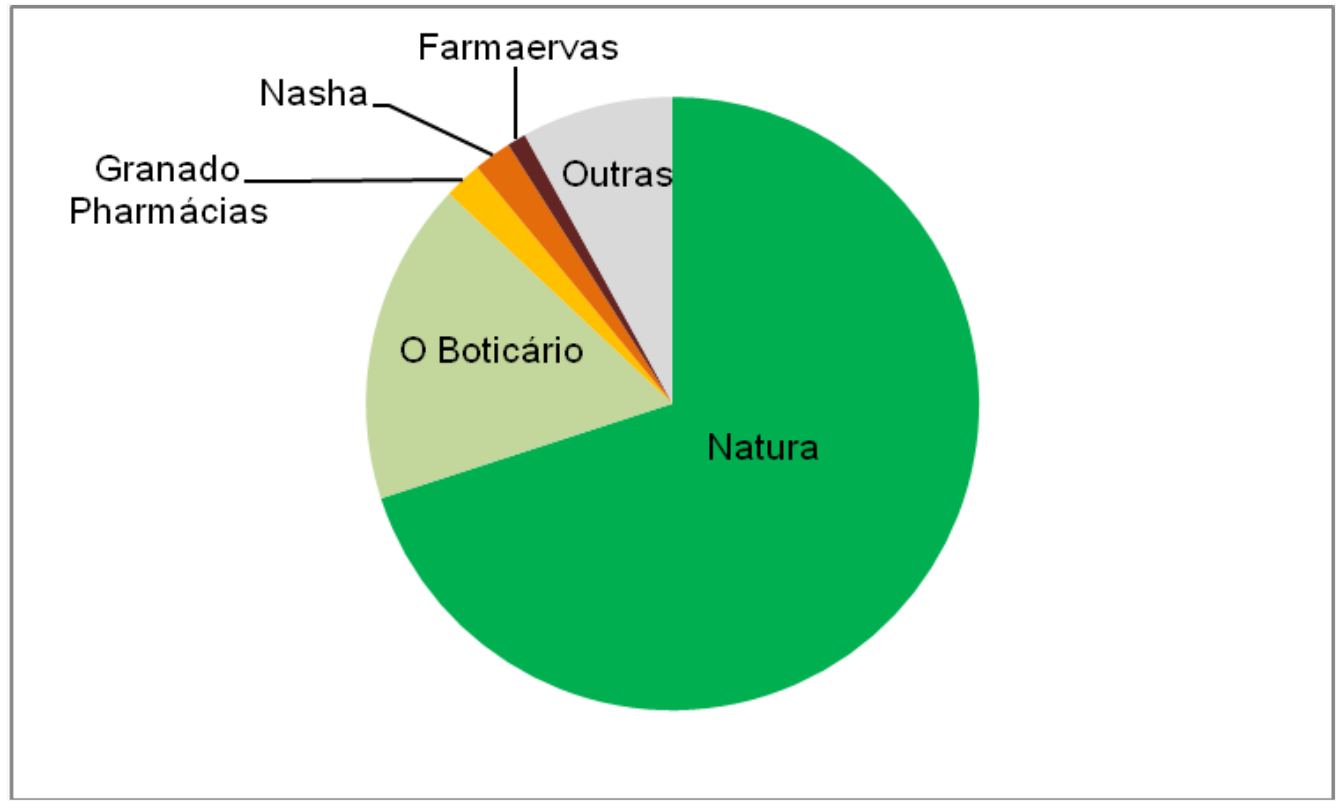

Fonte: Kline \& Company, 2011. Elaborado pela Autora. Consideradas apenas empresas de capital nacional. 
As demais empresas nacionais que desenvolvem produtos acabados e insumos com base na biodiversidade são representadas por indústrias de diferentes portes com destaque para a Surya, Amazon Secrets, Reserva Folio, Valmari, Magia dos Aromas, entre outras (Quadro 7). Na medida em que os produtos naturais têm ganhado cada vez mais espaço no mercado, o Brasil desponta entre os principais países detentores de matérias-primas diferenciadas e com alto potencial de mercado, especialmente associado a sua rica biodiversidade e com foco nos produtos da Amazônia.

Quadro 7 - Panorama Atual da Indústria Brasileira no Segmento de Biocosméticos

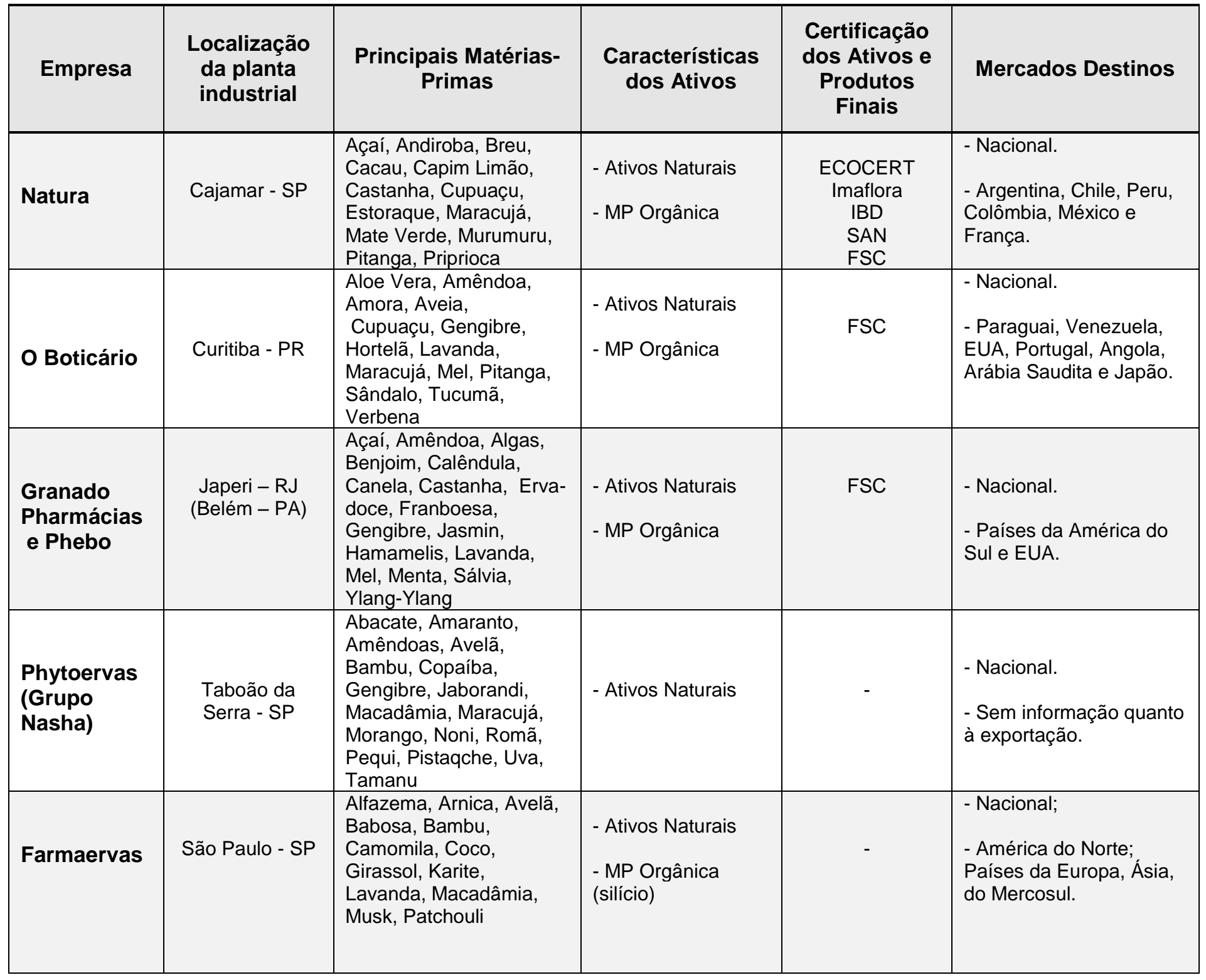




\begin{tabular}{|c|c|c|c|c|c|}
\hline $\begin{array}{l}\text { Éh! } \\
\text { Cosméticos } \\
\text { (Grupo }\end{array}$ & São Paulo-SP & $\begin{array}{l}\text { Alcachofra, Avelã, } \\
\text { Cacau, Camu, Cassis, } \\
\text { Coco Gengibre, Hortelã, } \\
\text { Lima, Menta, Noni }\end{array}$ & $\begin{array}{l}\text { - Ativos Naturais } \\
\text { - MP Orgânica }\end{array}$ & & $\begin{array}{l}\text { - Nacional. } \\
\text { - Sem informação quanto } \\
\text { à exportação }\end{array}$ \\
\hline $\begin{array}{l}\text { Reserva } \\
\text { Folio }\end{array}$ & $\begin{array}{c}\text { Nova Friburgo - } \\
\text { RJ }\end{array}$ & $\begin{array}{l}\text { Alecrim, Andiroba, } \\
\text { Babaçu, Cacau, } \\
\text { Castanha, Cupuaçu, } \\
\text { Macadâmia, Menta, Mel, } \\
\text { Murumuru, Palma, Ylang- } \\
\text { Ylang }\end{array}$ & $\begin{array}{l}\text { - Ativos Naturais } \\
\text { - MP Orgânica }\end{array}$ & $\begin{array}{l}\text { IBD } \\
\text { NOP }\end{array}$ & $\begin{array}{l}\text { - Regional e Nacional. } \\
\text { - França e Japão. }\end{array}$ \\
\hline Surya Brasil & $\begin{array}{l}\text { Taboão da } \\
\text { Serra - SP }\end{array}$ & $\begin{array}{l}\text { Açaí, Argila, Buriti, } \\
\text { Cacau, Canela, } \\
\text { Castanha, Cupuaçu, } \\
\text { Guaraná, Melão, } \\
\text { Morango, Murumuru, } \\
\text { Uccuba }\end{array}$ & $\begin{array}{l}\text { - Ativos Naturais } \\
\text { - MP Orgânica }\end{array}$ & $\begin{array}{l}\text { ECOCERT } \\
\text { COSMEBIO } \\
\text { USDA } \\
\text { VEGAN } \\
\text { PETA } \\
\text { FSC }\end{array}$ & $\begin{array}{l}\text { - Nacional. } \\
\text { - América do Norte, } \\
\text { Uruguai, Argentina, } \\
\text { Chile, Paraguai, } \\
\text { Colômbia, Suriname, } \\
\text { Portugal, Espanha, } \\
\text { França, Reino Unido, } \\
\text { Itália, Grécia, Chipre, } \\
\text { Arábia Saudita, Índia, } \\
\text { Taiwan, Hong Kong, } \\
\text { Japão e Austrália. }\end{array}$ \\
\hline $\begin{array}{l}\text { Amazon } \\
\text { Secrets }\end{array}$ & Botucatu - SP & $\begin{array}{l}\text { Açaí, Andiroba, Buriti, } \\
\text { Castanha, Copaíba, } \\
\text { Cupuaçu e Murumuru, }\end{array}$ & - Ativos Naturais & FSC & $\begin{array}{l}\text { - Em São Paulo (lojas e } \\
\text { spas) e lojas de } \\
\text { aeroportos } \\
\text { internacionais. } \\
\text { - 95\% dos produtos são } \\
\text { exportado para França, } \\
\text { Alemanha e Itália. }\end{array}$ \\
\hline Vitaderm & São Paulo - SP & $\begin{array}{l}\text { Açaí, Andiroba, } \\
\text { Castanha, Café, } \\
\text { Guaraná, Jaborandi, Juá, } \\
\text { Macadâmia }\end{array}$ & - Ativos Naturais & - & $\begin{array}{l}\text { - Nacional } \\
\text {-Em } 20 \text { países: } \\
\text { Argentina, Paraguai, } \\
\text { EUA, Alemanha, } \\
\text { Espanha, Portugal, } \\
\text { Reino Unido, Angola, } \\
\text { Moçambique, Japão e } \\
\text { Austrália }\end{array}$ \\
\hline Valmari & Diadema - SP & $\begin{array}{l}\text { Arnica, Argila, } \\
\text { Camomila, Castanha, } \\
\text { Guaraná, Macadâmia, } \\
\text { Outros extratos }\end{array}$ & $\begin{array}{l}\text { - Ativos Naturais } \\
\text { - MP Orgânica } \\
\text { (silício) }\end{array}$ & - & $\begin{array}{l}\text { - Nacional } \\
\text { - Alemanha, Portugal, } \\
\text { llha da Madeira }\end{array}$ \\
\hline $\begin{array}{l}\text { Magia dos } \\
\text { Aromas }\end{array}$ & Botucatu - SP & $\begin{array}{l}\text { Alfazema, Alecrim, } \\
\text { Arnica, Babaçu, Buriti, } \\
\text { Castanha, Camomila, } \\
\text { Calêndula, Citronela, } \\
\text { Copaíba, Cupuaçu, } \\
\text { Franboesa, Jasmaim, } \\
\text { Lavanda, Murumuru, } \\
\text { Ylang-Ylang }\end{array}$ & $\begin{array}{l}\text { - Ativos Naturais } \\
\text { - MP Orgânica }\end{array}$ & IBD & $\begin{array}{l}\text { - Nacional (exceto região } \\
\text { Norte). } \\
\text { - Exporta, mas não } \\
\text { informou os países. }\end{array}$ \\
\hline Florestas & Guarulhos - SP & $\begin{array}{l}\text { Açaí, Acerola, Abacate, } \\
\text { Alecrim, Buriti, Castanha, } \\
\text { Cacau, Copaíba, } \\
\text { Cupuaçu, Jaborandi, } \\
\text { Lavanda, Rosas, Sálvia }\end{array}$ & $\begin{array}{l}\text { - Ativos Naturais } \\
\text { - MP Orgânica }\end{array}$ & ECOCERT & $\begin{array}{l}\text { - Regional e alguns } \\
\text { pontos de vendas no } \\
\text { Brasil. } \\
\text {-França, Reino Unido, } \\
\text { Holanda, EUA, Japão e } \\
\text { Hong Kong }\end{array}$ \\
\hline Cassiopéia & Jarinu - SP & Aloe Vera & - MP Orgânica & IBD & - Regional \\
\hline
\end{tabular}

-onte: Homepage das empresas; Pesquisa e elaboração da Autora, 2011. 
Apesar de algumas tentativas de ampliar a capacidade de pesquisas aplicadas para o desenvolvimento de bioprodutos, uma rápida consulta ao conjunto de matérias-primas utilizadas na elaboração dos biocosméticos, conforme apresentamos acima, nos demonstram algumas limitações sobre 0 real aproveitamento da biodiversidade brasileira. Mesmo que os produtos oriundos da biodiversidade da Amazônia ainda sejam considerados inovadores, eles estão concentrados em um pequeno grupo de matérias-primas consideradas tradicionais, senão básicas, pelo menos por parte da população dessa região. Além disso, podemos também verificar uma "reprodução" desses tipos de produtos que contam de certa forma com mercados já consolidados graças às atuações de empresas pioneiras do segmento. De acordo com Costa (2009), esses processos estão relacionados à dependência de insumos importados e dos altos custos dos processos de pesquisa e desenvolvimento e, também, às graves indefinições de natureza normativa e regulatória.

Dessa forma, a capacidade de inovação tecnológica e das atividades de $P \& D$, a incorporação de novos insumos e princípios ativos, a produção de novas embalagens, entre outros, são alguns dos atributos indispensáveis para a competição dessas indústrias, sobretudo para o desenvolvimento de produtos mais diferenciados. E é nesse ambiente que se sobressai o reduzido grupo de indústrias nacionais, dentre elas, a Natura e $\bigcirc$ Boticário, exemplos representativos da atual liderança de alguns segmentos de mercado, principalmente em relação aos produtos inovadores e de alto valor agregado com ingredientes ativos da biodiversidade florestal. Por essa razão, selecionamos a seguir as principais experiências brasileiras em curso no uso de produtos naturais para cosméticos, como também, as iniciativas de pequenos empreendimentos na região Amazônica. 
No topo do ranking das indústrias brasileiras, a Natura atua na produção de cosméticos há quarenta e dois anos e detém 13\% do mercado nacional, com um faturamento de $\mathrm{R} \$ 5,1$ bilhões e crescimento de $21,1 \%$ em 2010 . Visualizando as oportunidades de crescimento no setor e, especialmente, do mercado dos produtos naturais, a empresa lançou em 2000 uma linha de produtos com base nos ativos da biodiversidade amazônica, a Natura Ekos.

A sede da Natura, assim como a principal unidade de produção e o centro de pesquisa e tecnologia (considerado um dos maiores centros de P\&D no setor de cosméticos da América Latina) encontram-se instalados no município de Cajamar, em São Paulo. Além dessa unidade de produção, a Natura construiu uma fábrica de extração de óleos vegetais para uso em sabonetes e um centro de pesquisa em Benevides (PA), no Parque Industrial da Central de Cooperativas de Trabalhadores Agroindústrias e Produtores Rurais Nova Amafrutas, empreendimento formado por cooperativas da região Nordeste do Pará.

A logística para a distribuição dos produtos é feita a partir de sete centros principais, localizados em Cajamar (SP), Jundiaí (SP), Matias Barbosa (MG), Uberlândia (MG), Simões Filho (BA), Jaboatão dos Guararapes (PE), e em Castanhal (PA) e Canoas (RS).

Além do mercado brasileiro, a Natura exporta para a França, México e países sul-americanos, com destaque para Argentina, Chile, Colômbia e Peru, e também alguns produtos são comercializados na Guatemala, El Salvador, Honduras e Bolívia. Em 2010, a empresa iniciou um novo modelo de produção e logística fora do Brasil, estabelecendo parcerias locais com a Argentina para a produção de algumas de suas linhas, sobretudo no que diz respeito ao segmento de perfumaria, prevendo a expansão desse novo modelo para 0 
México e Colômbia. Em Paris, foi construído um Centro Avançado de Tecnologia para o desenvolvimento de produtos, tecnologias e pesquisa de mercado, e registre-se também que o único ponto de venda da empresa encontra-se nessa cidade desde 2005. Diferentemente de sua estratégia comercial que é baseada no sistema de vendas diretas nos demais países onde tem operação, a Natura abriu uma loja em Paris, visando a partir dessa ‘cidade-piloto' firmar a marca na Europa e internacionalizar sua produção para outros países, especialmente no Leste Europeu, um mercado considerado com grandes potencialidades (Mapa 6).

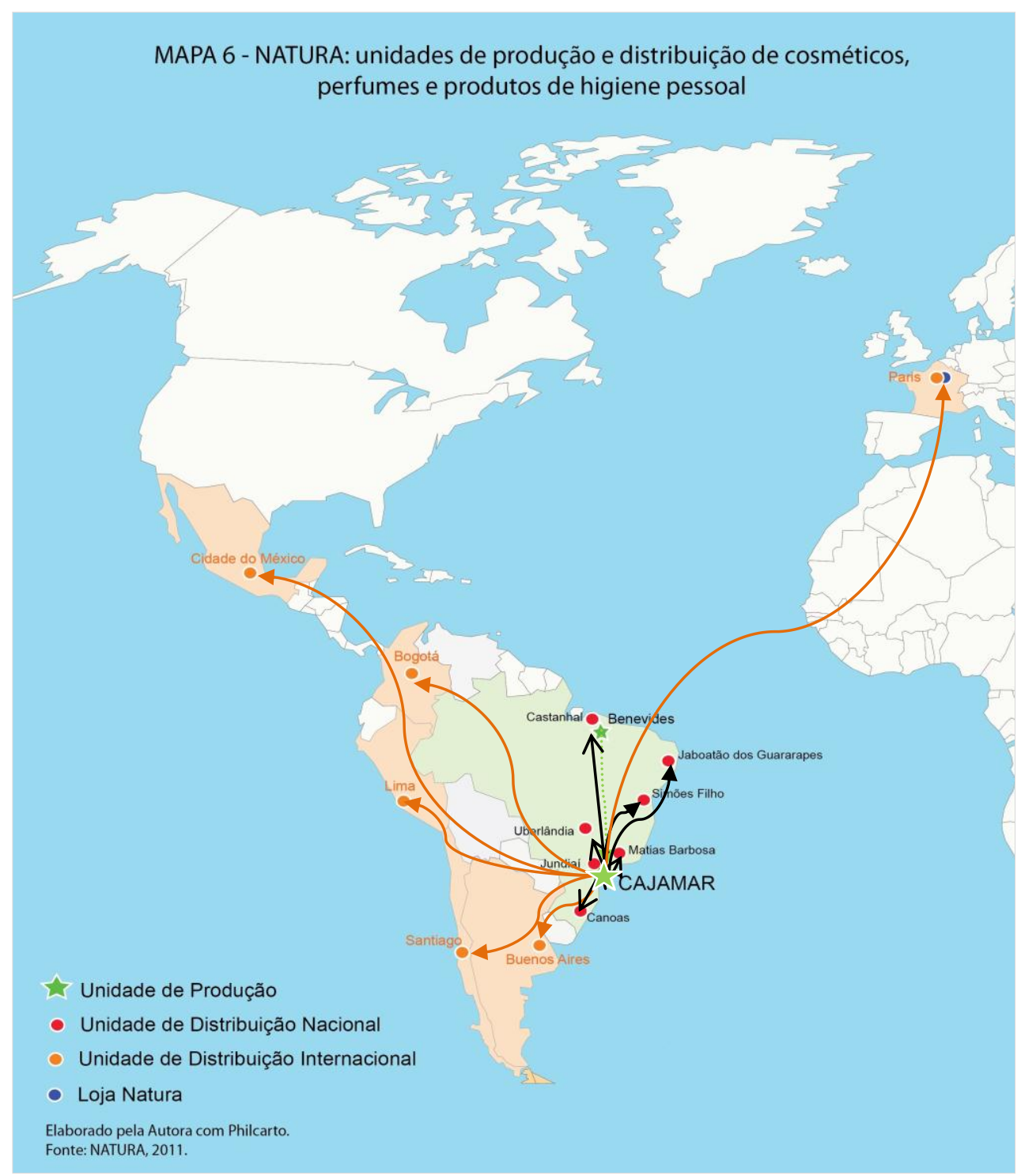


A Natura estabelece diversas articulações com os agentes da cadeia produtiva. As matérias-primas utilizadas nos bioprodutos da linha Ekos são fornecidas por comunidades extrativistas, cooperativas e grupos de pequenos produtores familiares. No entanto, na maioria das vezes, esses produtores não têm vínculo direto com a empresa, já que eles geralmente fazem os contratos para o fornecimento das matérias-primas com outras indústrias intermediárias, como a Beraca/Brasmazon e a Cognis, voltadas para o processamento dos produtos e padronização de insumos vegetais. E dessa forma, a rede de indústrias (intermediárias) produtoras de insumos são as responsáveis pela gestão da produção e inclusão das comunidades nesse processo.

Por outro lado, existem também projetos com parcerias diretas com as comunidades produtoras no Estado do Para, especialmente os pequenos produtores familiares de espécies oleaginosas para o fornecimento de óleo de semente de babaçu, cupuaçu, tucumã e buriti que são pré-processados na fábrica de Benevides. Registre-se, também, que além das cooperativas, a empresa Agropalma fornece óleo de palma para a formulação dos sabonetes $100 \%$ vegetais produzidos pela Natura. Além disso, segundo os seus representantes, parte dos insumos utilizados nas linhas de produtos para a pele, sobretudo para o tratamento cosmético antissinais, são adquiridos de outros países produtores de componentes mais diferenciados e com alta tecnologia.

Em 2010, a Natura destinou $R \$ 139$ milhões em atividades de P\&D e inovação tecnológica, equivalendo a $2,8 \%$ da sua receita líquida total nesse ano. Como resultados de inovação envolvendo o desenvolvimento de produtos e processos foram lançados cento e sessenta e oito novos itens (Tabela 13). 
Tabela 13 - Investimentos em P\&D e Inovação da Natura entre 2007 e 2010

\begin{tabular}{l|c|c|c|c}
\hline \multicolumn{1}{c|}{ Indicadores } & $\mathbf{2 0 0 7}$ & $\mathbf{2 0 0 8}$ & $\mathbf{2 0 0 9}$ & $\mathbf{2 0 1 0}$ \\
\hline Investimento em inovação (R\$ milhões) & 108,4 & 103,0 & 111,8 & 139,7 \\
Receita líquida em inovação (\%) & $3,4 \%$ & $2,8 \%$ & $2,6 \%$ & $2,8 \%$ \\
№ de produtos lançados (un.) & 183 & 118 & 103 & 168 \\
Índice de inovação* (\%) & $56,8 \%$ & $67,5 \%$ & $67,6 \%$ & $61,4 \%$ \\
\hline
\end{tabular}

Fonte: Relatório Anual 2010 Natura. * Receita Bruta dos últimos 12 meses proveniente dos produtos lançados nos últimos 24 meses versus a Receita Bruta total dos últimos 12 meses.

Atualmente, as atividades de P\&D e inovação da Natura estão voltadas basicamente para as pesquisas científicas de identificação de ativos da biodiversidade brasileira e viabilização de novos ingredientes em seus produtos; tem sido priorizado o desenvolvimento de pesquisas sobre os produtos para pele e cabelo, em decorrência da atual demanda de mercado para esses itens de cuidado pessoal; pesquisa sobre novas embalagens diferenciadas e que tenham o mínimo de impacto ambiental; pesquisa sobre novos modelos e métodos de segurança dos produtos, bem como de um 'sistema de cosmetovigilância', que monitora possíveis efeitos adversos dos produtos.

O desenvolvimento das pesquisas e inovação de novos produtos e processos é realizado internamente, como também por meio de parcerias internacionais com grandes centros de referência mundial, como o Massachusetts Institute of Technology, de Boston (EUA). Além disso, a Natura conta com o Programa Campus de Inovação Tecnológica, que criado em 2007, tem o apoio do CNPq, FAPESP e da Finep para o fomento de parcerias com universidades e centros de pesquisa de todo o Brasil. E, ainda, segundo o Relatório anual, em 2010, a empresa obteve apoio financeiro para projetos de P\&D voltados à inovação, capacitação industrial, logística e tecnologia da 
informação, tendo recebido $\mathrm{R} \$ 900$ mil de apoio da Finep e, ainda, $\mathrm{R} \$ 135,7$ milhões de financiamento do BNDES.

Para garantir a sustentabilidade na extração e uso das matérias-primas da biodiversidade brasileira, a Natura possui um "Programa de Certificação de Ativos Naturais ou Vegetais", instrumento que promove o manejo sustentável de áreas florestais e de cultivo, tendo certificado trinta e seis matérias-primas vegetais para uso cosmético ou também em bebidas (chás) (Tabela 14).

Tabela 14 - Ativos Vegetais Certificados pela Natura entre 2005 e 2010

\begin{tabular}{l|c|c|c|c|c|c}
\hline \multicolumn{1}{c|}{ Ativos } & 2005 & 2006 & 2007 & 2008 & 2009 & 2010 \\
\hline $\begin{array}{l}\text { Total de } \\
\text { ativos } \\
\text { certificados }\end{array}$ & 16 & 22 & 24 & 26 & 31 & 36 \\
\hline $\begin{array}{l}\text { Porcentagem } \\
\text { do total de } \\
\text { espécies } \\
\text { certificadas }\end{array}$ & $46 \%$ & $63 \%$ & $51 \%$ & $54 \%$ & $58 \%$ & $61 \%$ \\
\hline
\end{tabular}

* considerados insumos vegetais sob a forma de ceras, óleos, extratos, óleos essenciais ou in natura (cosméticos e chás). Fonte: Relatórios Anuais Natura (2005 a 2010).

Dentre as empresas de capital nacional, a Natura detém o maior número de parcerias para certificação de produtos finais e matérias-primas baseadas nos critérios dos principais organismos credenciados no Brasil, entre eles, os selos de certificação orgânica de quatro entidades, o IBD (do Instituto Biodinâmico), ECOCERT (organismo francês que também tem representação no Brasil), OIA (Organização Internacional Agropecuária, certificadora parceira na Argentina) e o selo IMO (Instituto de Mercado Ecológico, certificadora suíça com sede em São Paulo); e ainda os selos disponibilizados pelo IMAFLORA para a certificação florestal com FSC (Forest Stewardship Council) e de agricultura sustentável com o SAN (Sustaintable Agriculture Network) (Anexo 8). 


\subsubsection{Bioindústrias de Insumos}

A Beraca, a Croda e a Centro Flora formam o grupo das grandes empresas intermediárias que fabricam e/ou processam insumos naturais para 0 abastecimento da indústria cosmética, como também para outros segmentos industriais, especialmente de bebidas, extratos, alimentos, fármacos e inseticidas. Além dessas, outras indústrias de menor porte, como a Ervativa e a Magama, instaladas na Amazônia Brasileira, também desenvolvem insumos e extratos vegetais padronizados utilizados principalmente na produção de fragrâncias (Quadro 8).

Quadro 8 - Principais Indústrias Nacionais de Insumos para Cosméticos*

\begin{tabular}{|c|c|c|c|c|c|}
\hline Empresa & Localização & $\begin{array}{c}\text { Principais } \\
\text { Matérias-Primas }\end{array}$ & $\begin{array}{c}\text { Características } \\
\text { dos Ativos }\end{array}$ & $\begin{array}{l}\text { Certificação } \\
\text { dos Insumos }\end{array}$ & $\begin{array}{l}\text { Mercados } \\
\text { Destinos }\end{array}$ \\
\hline $\begin{array}{l}\text { Beraca } \\
\text { Sabará/ } \\
\text { Brasmazon }\end{array}$ & $\begin{array}{l}\text { Santa Bárbara } \\
\text { D'oeste - } \\
\text { SP/Ananindeua- } \\
\text { PA }\end{array}$ & $\begin{array}{l}\text { Açaí, Andiroba, } \\
\text { Babaçi, Bacuri, } \\
\text { Buriti, Castanha, } \\
\text { Cerejeira, Cupuaçu, } \\
\text { Estoraque, } \\
\text { Murumuru, Patauá, } \\
\text { Pracaxi, Priprioca, } \\
\text { Ucuúba, Tucumã }\end{array}$ & $\begin{array}{l}\text { óleos essenciais, } \\
\text { vegetais e extratos }\end{array}$ & ECOCERT & $\begin{array}{l}\text { - Nacional. } \\
\text { - Exporta para } \\
\text { mais de } 40 \\
\text { países. }\end{array}$ \\
\hline $\begin{array}{l}\text { Croda do } \\
\text { Brasil/ } \\
\text { Crodamazon }\end{array}$ & $\begin{array}{l}\text { Campinas - } \\
\text { SP/Manaus - } \\
\text { AM }\end{array}$ & $\begin{array}{l}\text { Andiroba, Babaçu, } \\
\text { Buriti, Castanha, } \\
\text { Cacau, Cupuaçu, } \\
\text { Maracujá, } \\
\text { Murumuru, Pequi }\end{array}$ & $\begin{array}{l}\text { óleos essenciais, } \\
\text { vegetais e extratos }\end{array}$ & IMAFLORA & $\begin{array}{l}\text { - Nacional. } \\
\text { - Exporta para } \\
\text { diversos países. }\end{array}$ \\
\hline Centro Flora & Botucatu - SP & $\begin{array}{l}\text { Açaí, Acerola, Aloe } \\
\text { Vera, Aniz, } \\
\text { Blueberry, Cacau, } \\
\text { Chá Verde, } \\
\text { Camomila, Camu } \\
\text { Camu, Erva Doce, } \\
\text { Guaraná, } \\
\text { Hamamelis, Jambu, } \\
\text { Mate, Uva }\end{array}$ & $\begin{array}{l}\text { óleos essenciais, } \\
\text { vegetais e extratos }\end{array}$ & $\begin{array}{l}\text { ECOCERT } \\
\text { USDA } \\
\text { IBD }\end{array}$ & $\begin{array}{l}\text { - Nacional. } \\
\text { - Exporta para } \\
\text { diversos países. }\end{array}$ \\
\hline Ervativa & $\begin{array}{l}\text { Santa Isabel do } \\
\text { Pará - PA }\end{array}$ & $\begin{array}{l}\text { Açaí, Cupuaçu, } \\
\text { Estoraque, Guaraná, } \\
\text { Jambu, Mastruz, } \\
\text { Patchouli, Priprioca }\end{array}$ & $\begin{array}{l}\text { óleos essenciais, } \\
\text { vegetais e extratos }\end{array}$ & - & $\begin{array}{l}\text { - Regional. } \\
\text { - Exportações } \\
\text { pontuais. }\end{array}$ \\
\hline Magama & Manaus - AM & $\begin{array}{l}\text { Açaí, Andiroba, } \\
\text { Buriti, Camu-Camu, } \\
\text { Castanha, Copaíba, } \\
\text { Cupuaçu, Guaraná, } \\
\text { Murumuru, Pauu } \\
\text { Rosa, Tucumã, } \\
\text { Urucum, Urucuri, }\end{array}$ & $\begin{array}{l}\text { óleos essenciais, } \\
\text { vegetais e extratos }\end{array}$ & FSC & $\begin{array}{l}\text { - Regional. } \\
\text { - Exportações } \\
\text { pontuais, } \\
\text { principalmente } \\
\text { para os EUA. }\end{array}$ \\
\hline
\end{tabular}

Dentre outras produtoras de insumos, destacam-se a Givaudan e a Cognis. Fonte: Homepage das empresas; Pesquisa e Elaboração da Autora, 2012. 
Dentre as indústrias produtoras de insumos, destaca-se a atuação da Beraca Sabará que desenvolve inúmeros produtos com base na biodiversidade, especialmente das matérias-primas amazônicas e fornece insumos para diversas indústrias brasileiras e estrangeiras. A Beraca é a maior produtora de insumos da biodiversidade amazônica utilizada nas indústrias de cosméticos, além de outros ingredientes destinados a fabricação de alimentos, sanitizantes e de nutrição e saúde animal do país. A empresa, com sede em Santa Bárbara D'Oeste (SP), teve em 2010 o faturamento líquido de mais de $\mathrm{R} \$ 110$ milhões, respondendo a um crescimento de $33 \%$ em relação a 2007 , sendo os insumos para cosméticos os principais responsáveis por essa expansão.

O desenvolvimento de insumos derivados de frutos amazônicos foi impulsionado quando a empresa adquiriu parte da Brasmazon, em 2001, pequena indústria paraense, produtora de óleos, corantes e resinas, que fornecia insumos para diversas indústrias nacionais e também exportava para diversos países. A Brasmazon esteve incubada no PIEBT, Incubadora de Empresas da Universidade Federal do Pará, e no início de suas atividades montou um banco de dados sobre a flora regional a partir do levantamento de potenciais matérias-primas junto às comunidades locais e do acervo de pesquisas da UFPA sobre espécies oleaginosas. Com a aquisição total da Brasmazon, em 2003, a Beraca construiu uma refinaria em Ananindeua (região metropolitana de Belém) para as primeiras etapas de refinamento dos óleos, facilitando também a proximidade com os fornecedores comunitários.

As matérias-primas são adquiridas de cerca de quarenta comunidades produtoras (Figura 7) e a extração, o processamento e a padronização dos 
Figura 7 - Principais Operações da BERACA com os Insumos da Biodiversidade

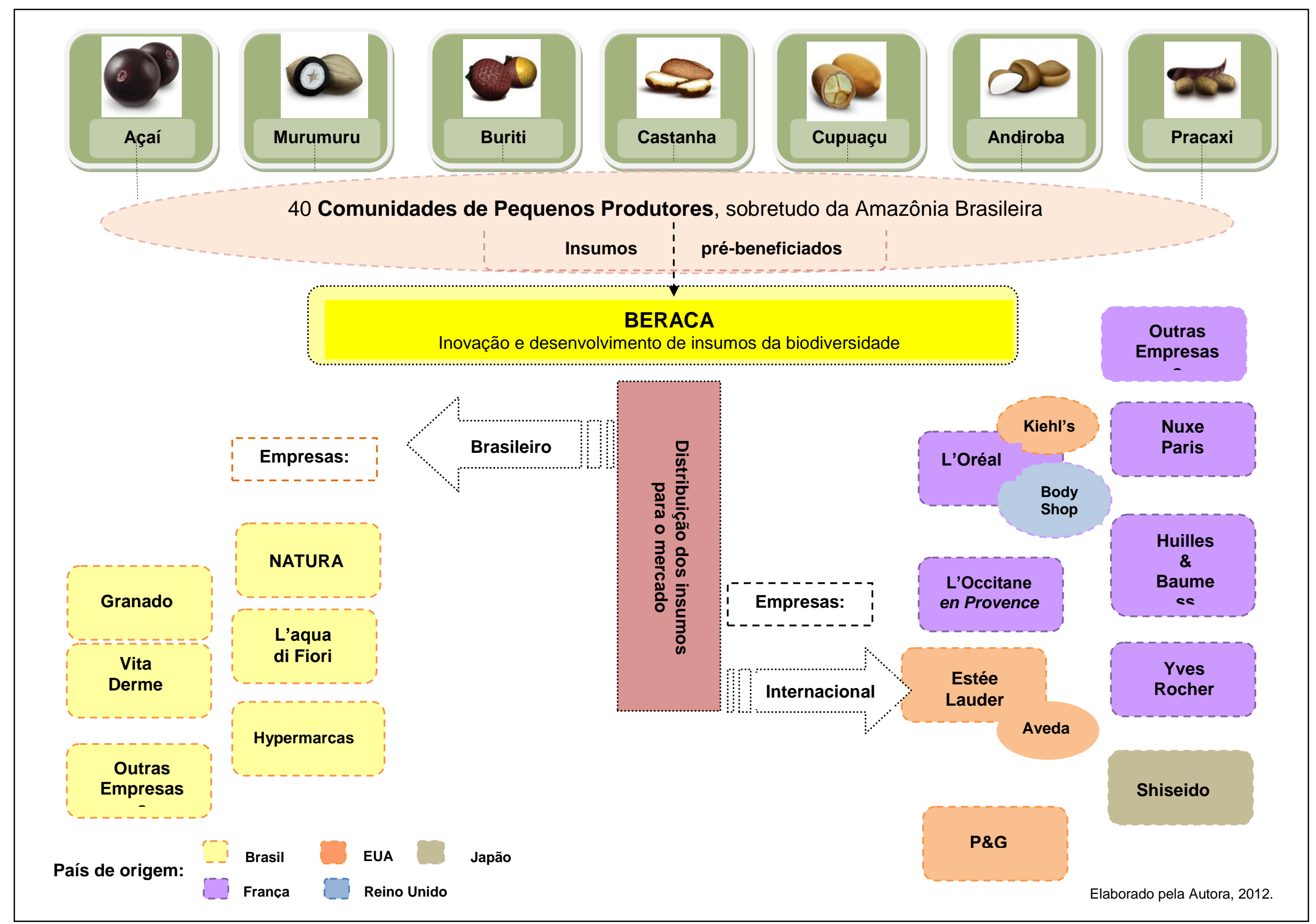


óleos ou manteigas de frutos e sementes, como açaí, andiroba, babaçu, murumuru e urucum são realizados a partir de tecnologias e processos desenvolvidos pela própria empresa. Após essas etapas de produção, os insumos são repassados para outras indústrias intermediárias, também produtoras de aromas e fragrâncias ou empresas responsáveis pela fabricação de produtos acabados.

Os ingredientes naturais e orgânicos compostos de ativos extraídos da biodiversidade são fornecidos por comunidades dos estados do Acre, Amazonas, Amapá, Roraima, Pará, Maranhão e, também, Minas Gerais. A francesa, Yves Rocher, foi a primeira grande empresa a firmar contrato com a Beraca e atualmente é uma das maiores compradoras de óleo de andiroba orgânico. Além dessa, a Beraca fornece para as principais empresas mundiais envolvidas na produção de biocosméticos (Natura, Estée Lauder, L'Occitane, Aveda, Kiehl's, etc), como também para indústrias menores da região Amazônica e do país (Anexo 9).

Segundo a Beraca, 50\% dos ingredientes são destinados à exportação para mais de quarenta países e trinta e três distribuidores de todo o mundo, sendo o mercado europeu, o principal destino da produção. Em 2008, inaugurou escritório comercial em Paris e para este ano ainda está prevista a abertura de mais um escritório em Nova York (Mapa 7).

Com a crescente demanda de mercado, o investimento em pesquisa e inovação de produtos e processos envolve $3 \%$ do faturamento total, visando desenvolver insumos com alto valor agregado, ampliar e diversificar sua produção. 


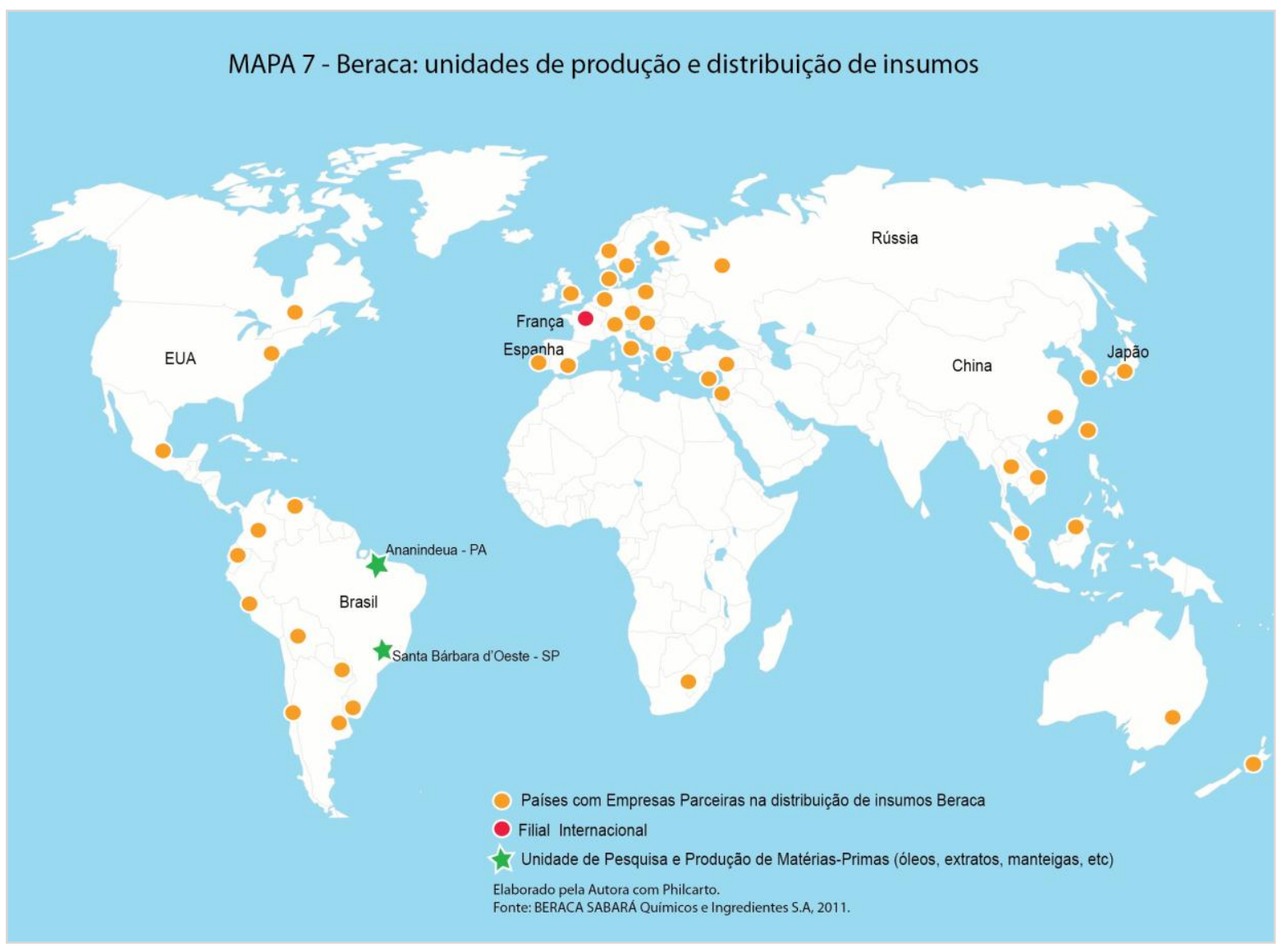

A Beraca faz o rastreamento da origem de todas as matérias-primas utilizadas em seus insumos, investindo no treinamento e capacitação das comunidades produtoras e, além disso, as exigências de normatização se estendem ao longo de todas as etapas produtivas, possuindo as principais certificações disponíveis no mercado, como as que são fornecidas pela Ecocert para produtos orgânicos e que serão detalhadas no último item deste capítulo. Em 2005, quando a empresa deu início às certificações de matérias-primas orgânicas, cerca de $20 \%$ das comunidades produtoras receberam os atestados Ecocert e, atualmente, $60 \%$ delas possuem esse tipo de certificação. No entanto, registrem-se os altos custos dos processos de certificação das matérias-primas, que chegam a envolver valores em torno de quarenta mil reais por produto (Beraca, 2011). 


\subsubsection{O Segmento Emergente das Bioindústrias na Amazônia Brasileira}

$\mathrm{Na}$ Amazônia, destacam-se as recentes iniciativas de empresas instaladas nessa região e que têm procurado viabilizar o aproveitamento dos tradicionais e novos produtos regionais. Dentre os aspectos observáveis, o mais notável deles se refere à valorização dos centros, institutos de pesquisa e universidades dessa região e o importante papel da aliança entre ciência, tecnologia e sistemas de inovação tecnológica aplicados especificamente no desenvolvimento de novos bioprodutos (Quadro 9). A expansão desses pequenos empreendimentos industriais introduz ali uma tendência e um novo paradigma no processo produtivo em geral e, ao mesmo tempo, um estratégico vetor de modernização associada aos padrões tecnológicos atualmente vigentes nos mercados nacionais e internacionais (COSTA, W. M., 02009).

\section{Quadro 9 - Principais Bioindústrias na Amazônia Brasileira*}

\begin{tabular}{|c|c|c|c|c|}
\hline Empresas & $\begin{array}{l}\text { Localização } \\
\text { da unidade de } \\
\text { produção }\end{array}$ & $\begin{array}{c}\text { Principais } \\
\text { Matérias-Primas }\end{array}$ & $\begin{array}{c}\text { Certificação } \\
\text { dos Ativos/ } \\
\text { Produtos } \\
\text { Finais }\end{array}$ & $\begin{array}{c}\text { Mercados } \\
\text { Destinos }\end{array}$ \\
\hline $\begin{array}{l}\text { Fluídos da } \\
\text { Amazônia } \\
\text { (Chamma) }\end{array}$ & Belém - PA & $\begin{array}{l}\text { Açaí, Andiroba, } \\
\text { Castanha, Copaíba, } \\
\text { Cupuaçu, Guaraná }\end{array}$ & - & $\begin{array}{l}\text { - Regional; e } \\
\text { principais capitais } \\
\text { - Portugal e } \\
\text { França. }\end{array}$ \\
\hline Juruá & Belém - PA & $\begin{array}{l}\text { Açaí, Amor Crescido, } \\
\text { Andiroba, Buriti, } \\
\text { Cacau, Castanha, } \\
\text { Cupuaçu, Guaraná, } \\
\text { Jaborandi, Manga, } \\
\text { Mel, Patchouli, } \\
\text { Priprioca }\end{array}$ & - & $\begin{array}{l}\text { - Local e } \\
\text { Regional. } \\
\text { - EUA, Alemanha, } \\
\text { França, Portugal, } \\
\text { Espanha, Coréia } \\
\text { do Sul e Japão. }\end{array}$ \\
\hline $\begin{array}{l}\text { Insumos da } \\
\text { Amazônia }\end{array}$ & Belém - PA & $\begin{array}{l}\text { Açaí, Andiroba, Buriti, } \\
\text { Castanha, Copaíba, } \\
\text { Cravo, Jaborandi, } \\
\text { Murumuru, Patchouli, } \\
\text { Ylang-Ylang }\end{array}$ & - & $\begin{array}{l}\text { - Local, Regional; } \\
\text { - Pontualmente } \\
\text { para a Venezuela, } \\
\text { Suíça, Portugal, }\end{array}$ \\
\hline $\begin{array}{l}\text { Pronatus da } \\
\text { Amazônia }\end{array}$ & Manaus - AM & $\begin{array}{l}\text { Andiroba, Copaíba, } \\
\text { Buriti, Cupuaçu, } \\
\text { Crajiru }\end{array}$ & - & $\begin{array}{l}\text { - Local, Regional } \\
\text { - Pontualmente } \\
\text { para a Venezuela, } \\
\text { EUA e alguns } \\
\text { países da Europa }\end{array}$ \\
\hline
\end{tabular}




\begin{tabular}{|l|l|l|l|l|}
\hline $\begin{array}{l}\text { Pharmakos da } \\
\text { Amazônia }\end{array}$ & Manaus - AM & $\begin{array}{l}\text { Arnica, Buriti, } \\
\text { Copaíba, Urucum }\end{array}$ & - Local e Regional \\
\hline Amazon Ervas & Manaus - AM & $\begin{array}{l}\text { Amêndoa, Andiroba, } \\
\text { Copaíba, Eucalipto, } \\
\text { Rosa Mosqueta, } \\
\text { Uvas. }\end{array}$ & - & - Local e Regional \\
\hline
\end{tabular}

* A Natura e a Beraca (Beraca/Brasmazon) possuem plantas industriais na região, respectivamente, nos municípios de Benevides e Ananindeua. Nessas unidades são realizadas as primeiras etapas do processamento das matérias-primas e, em seguida, são distribuídas e utilizadas nas demais etaps de produção em suas fábricas principais, localizadas no estado de São Paulo. Fonte: Homepage das empresas; Pesquisa e Elaboração da autora, 2012.

Além desses empreendimentos, algumas das grandes indústrias que desenvolvem produtos baseados em ativos e compostos naturais da Amazônia também construíram plantas industriais de produção na região, no caso a Natura, a L'Occitane en Provence, a Croda e a Beraca, onde realizam as primeiras etapas de processamento das matérias-primas para posterior distribuição e novo tratamento em suas sedes industriais instaladas em municípios do estado de São Paulo (exceto a francesa L'Occitane, como já destacado neste trabalho).

Conforme apontado na nossa pesquisa de mestrado, há atualmente uma intensa articulação de todas as etapas de produção com as atividades de P\&D das empresas e dos centros e instituições de pesquisa da região e de fora dela. O desenvolvimento desses empreendimentos na região amazônica envolve articulações de diferentes posições com os atores locais, regionais, do país e do exterior, entretanto, por se tratar de um segmento incipiente e em fase de estruturação, ele ainda não se encontra consolidado em todas as etapas da cadeia produtiva e não é integrado sob a forma de redes completas.

Essas empresas estão voltadas para a produção final e comercialização direta de seus produtos nos mercados consumidores. Elas adquirem parte dos insumos desenvolvidos por outras empresas do setor, como da 
Beraca/Brasmazon, Crodamazon e da Ervativa, por exemplo, e as matériasprimas são fornecidas e pré-beneficiadas por cooperativas e comunidades de pequenos produtores, sobretudo, nos estados do Amazonas e Pará. Porém, existem os casos em que os produtos podem ser fornecidos por intermediários da cadeia produtiva. Dentre as espécies fornecidas, o açaí, a andiroba, o buriti, a castanha, o cupuaçu, o murumuru e o tucumã representam os ativos mais aplicados nos produtos, sendo esse quadro similar nas grandes indústrias

As indústrias produtoras de biocosméticos na Amazônia brasileira são formadas majoritariamente por empresas de pequeno porte. Em Belém, a Juruá e a Insumos da Amazônia representam o grupo das pequenas bioindústrias regionais, em fase de expansão, e que têm como trajetória comum, um forte vínculo com as universidades e instituições de pesquisas locais. Dentre os fatores relevantes, destaca-se que a Juruá esteve associada ao PIEBT e contava com apoio especializado para interagir com as diversas áreas de pesquisas realizadas pelos departamentos e institutos da UFPA. A Insumos da Amazônia surgiu mediante projeto desenvolvido por seus proprietários, que também são professores da UFPA e, dessa forma, tiveram oportunidade de conciliar a pesquisa e os mecanismos institucionais de financiamento oferecidos pelas universidades e agências de fomento, com o desafio de utilizar o potencial da biodiversidade em produtos inovadores e de alto valor agregado (MIGUEL, 2007).

No PIEBT, as empresas incubadas (associadas e residentes) têm acesso privilegiado aos laboratórios, projetos desenvolvidos pelos pesquisadores da UFPA, estimulando dessa forma o processo de inovação para o desenvolvimento de novos bioprodutos. A Juruá desenvolveu pelo 
diversos inovadores quando esteve incubada, demonstrando, dessa forma, a importância do intercâmbio com os pesquisadores de universidades em geral.

Em Manaus, a Pronatus do Amazonas, Phárrmakos (inicialmente incubadas no Centro de Incubação e Desenvolvimento Empresarial - CIDE) e a Amazon Ervas são as pequenas empresas pioneiras na produção de cosméticos do estado do Amazonas, iniciando suas atividades como farmácias de manipulação com base na flora regional. Essas empresas atuam desde o processamento das matérias-primas até a comercialização final dos produtos nos mercados consumidores, sendo que duas delas contam com lojas e franquias em Manaus e na região.

Há também aquelas bioindústrias mais consolidadas, como é o caso da Fluídos da Amazônia (Chamma da Amazônia) de Belém, que após cinco anos de incubação no PIEBT, construiu uma fábrica e montou um sistema de franquias na região e em várias localidades do Brasil, com lojas nas principais cidades do Norte, Nordeste e Sudeste. Um dos seus diferenciais está relacionado ao investimento na comunicação visual de seus produtos com embalagens sofisticadas que valorizam a cultura regional para disputar o nicho de mercado com as empresas de fora da região (MIGUEL, L. M., 2007).

Diversas pesquisas de identificação das características bioquímicas de frutos tradicionalmente conhecidos na região são realizadas pela EMBRAPA, pelo INPA e MPEG, que visam, sobretudo, o desenvolvimento de tecnologias para a sua domesticação e ampliação de suas áreas de cultivo, como também o seu aproveitamento industrial. Dentro das possibilidades de uso da diversidade de matérias-primas, algumas delas têm sido amplamente 
aproveitadas nos produtos e insumos desenvolvidos pelas pequenas indústrias, como apresentado no Quadro 9.

Destaque especial deve ser dado às novas bases técnicas dos sistemas de manejo florestal que estão sendo introduzidas atualmente nas produções das cooperativas e pequenas comunidades, muitas delas com apoio de diversas ONGs e programas governamentais. Dessa forma, mesmo que as empresas de pequeno porte (como também as comunidades) ainda não disponibilizem de recursos suficientes que Ihes permitam certificar as espécies

e os extratos, registre-se que esses pequenos empreendimentos industriais também têm estimulado a organização dos produtores a fim de assegurar a qualidade e a regularidade do fornecimento das matérias-primas (uma das limitações desses sistemas), baseados em tecnologias adequadas de plantio, cultivo, coleta e secagem para cada tipo de espécie.

\subsection{Certificações dos Biocosméticos}

Outra tendência relacionada aos cosméticos diz respeito à certificação e ao selo de origem das matérias-primas que atestam a qualidade dos produtos. Esse aspecto tem se tornado cada vez mais presente, notadamente naquelas indústrias mais inovadoras que desenvolvem produtos com alto valor agregado e, sobretudo, voltados também para exportação. Diversos institutos e agências, como a Ecocert e a Cosmebio, na França, a Soil Association, no Reino Unido, a BDIH, na Alemanha, a ICEA, na Itália e a Ecogarantie, na Bélgica, destacamse entre as principais entidades certificadoras de produtos e, especialmente, de produtos naturais (Quadro 10). Registre-se que cerca de mil indústrias ou 
produtores envolvidos na cadeia produtiva de cosméticos e mais de dez mil produtos estão inseridos na rede de controle e certificação de origem e qualidade das matérias-primas utilizadas pelas indústrias instaladas na Europa (SHIELD, 2009).

Quadro 10 - Principais Selos de Certificação de Produtos Naturais e/ou Orgânicos

\begin{tabular}{l|c}
\hline \multicolumn{1}{c|}{ Selos de certificação de Produtos naturais e/ou Orgânicos } & Origem dos Selos \\
\hline NOP, NPA, NSF, Oasis e OPCAI & EUA \\
\hline CerTech & Canadá \\
\hline Ecocert e Cosmebio (Bio ou Eco) & França \\
\hline BDHI, Demeter & Alemanha \\
\hline $\begin{array}{l}\text { Organic Farmers and Gowers, Organic Food Federation e Soil } \\
\text { Association }\end{array}$ & Inglaterra \\
\hline Natrue e EcoGarantie & Bélgica \\
\hline AIAB (ICEA) e CCPB & Itália \\
\hline White Swan & Suécia \\
\hline IMO & Suíça \\
\hline Organic Trust & Irlanda \\
\hline IBD e Ecocert Brasil & Brasil \\
\hline
\end{tabular}

Fonte: Organonatural, 2009; Organic Monitor, 2011; Ecocert Brasil, 2011, IBD, 2011.

Dentre esses organismos, as certificadoras francesas se sobressaem nos processos de controle dos cosméticos, sobretudo a ECOCERT. Esse organismo, fundado em 1991 e aprovado pelo Ministério de Agricultura, Pesca e Alimentação e Ministério de Economia e Finanças, apresenta rigoroso nível de regulamentação frente aos produtos cosméticos convencionais. A ECOCERT é referência mundial na certificação de alimentos bio/orgânicos (identificado com o selo AB, "Agriculture Biologique") e de produtos naturais, 
biológicos e/ou orgânicos no setor de cosméticos e, segundo dados recentes, cerca de $70 \%$ dos produtos cosméticos na França utilizam os selos desse organismo (ECOCERT, 2011).

A certificação ECOCERT é definida por diferentes tipos de controle de qualidade, sendo utilizados por esse organismo os métodos e critérios de análises elaborados a partir das especificações desenvolvidas pela Cosmebio, uma associação com mais de trezentos e cinquenta membros franceses e estrangeiros, formada por uma rede de diversos laboratórios especializados em produtos naturais, distribuidores, fornecedores, entre outros.

Dessa forma, a Cosmebio criou níveis de certificação para os biocosméticos correspondentes a dois tipos de selos: o BIO e o ECO. Os cosméticos certificados com o selo BIO são denominados de "cosméticos biológicos" e devem conter em suas formulações no mínimo $95 \%$ de ingredientes naturais (ou de origem natural), dos quais $10 \%$ devem ser provenientes de agricultura biológica ou orgânica. Os 5\% restantes podem ser compostos por ingredientes sintéticos ${ }^{20}$, mas sendo permitido o uso de apenas determinados conservantes, dentre eles, o benzoato de sódio, álcool benzílico, ácido fórmico, ácido propiônico ou propílico (e seus sais), ácido salicílico (e seus sais), ácido sórbico (e seus sais). O uso de fragrâncias sintéticas, colorantes, silicone e glicol são proibidos nas formulações desses tipos de produtos (Figura 8).

\footnotetext{
${ }^{20}$ Ingrediente natural: ingrediente vegetal, animal, mineral ou extratos marinho proveniente diretamente de exploração agrícola, não transformado e obtido exclusivamente por processos físicos.

Ingrediente de origem natural: ingrediente natural transformado segundo procedimentos químicos autorizados.

Ingrediente sintético: ingrediente proveniente de processos químicos e autorizados pelo selo Cosmebio (Cosmebio, 2011).
} 


\section{Figura 8 - Certificação de Cosméticos Biológicos}

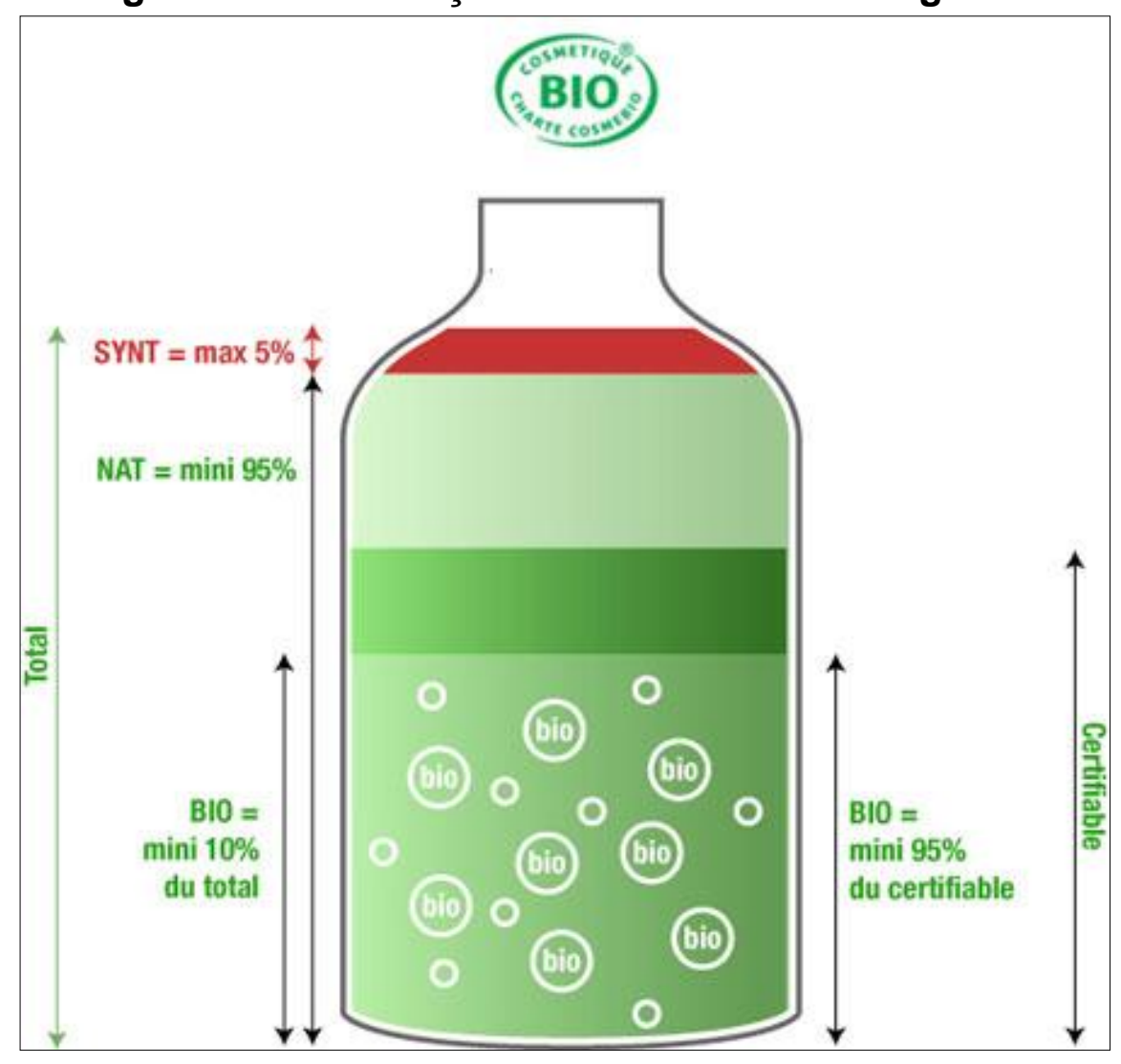

Fonte: COSMEBIO, 2011.

Já o selo ECO classifica os "cosméticos ecológicos" e tem como exigência de certificação que o produto final contenha no mínimo $50 \%$ de ingredientes naturais (ou de origem natural), sendo que $5 \%$ desse total devem ser provenientes de agricultura biológica/orgânica e são permitidos no máximo $5 \%$ de substâncias sintéticas, como também os conservantes liberados pela rigorosa lista citada anteriormente (Figura 9).

Todas as informações sobre a certificação ECOCERT são detalhadas nos rótulos dos produtos finais e evidentemente a entidade proíbe a realização de testes bio-físico-químicos em animais. Os controles dos produtos certificados são realizados duas vezes por ano e o organismo somente 
disponibiliza as licenças e os selos para os produtos que atestem todos os processos de fabricação.

Figura 9 - Certificação dos Cosméticos Ecológicos

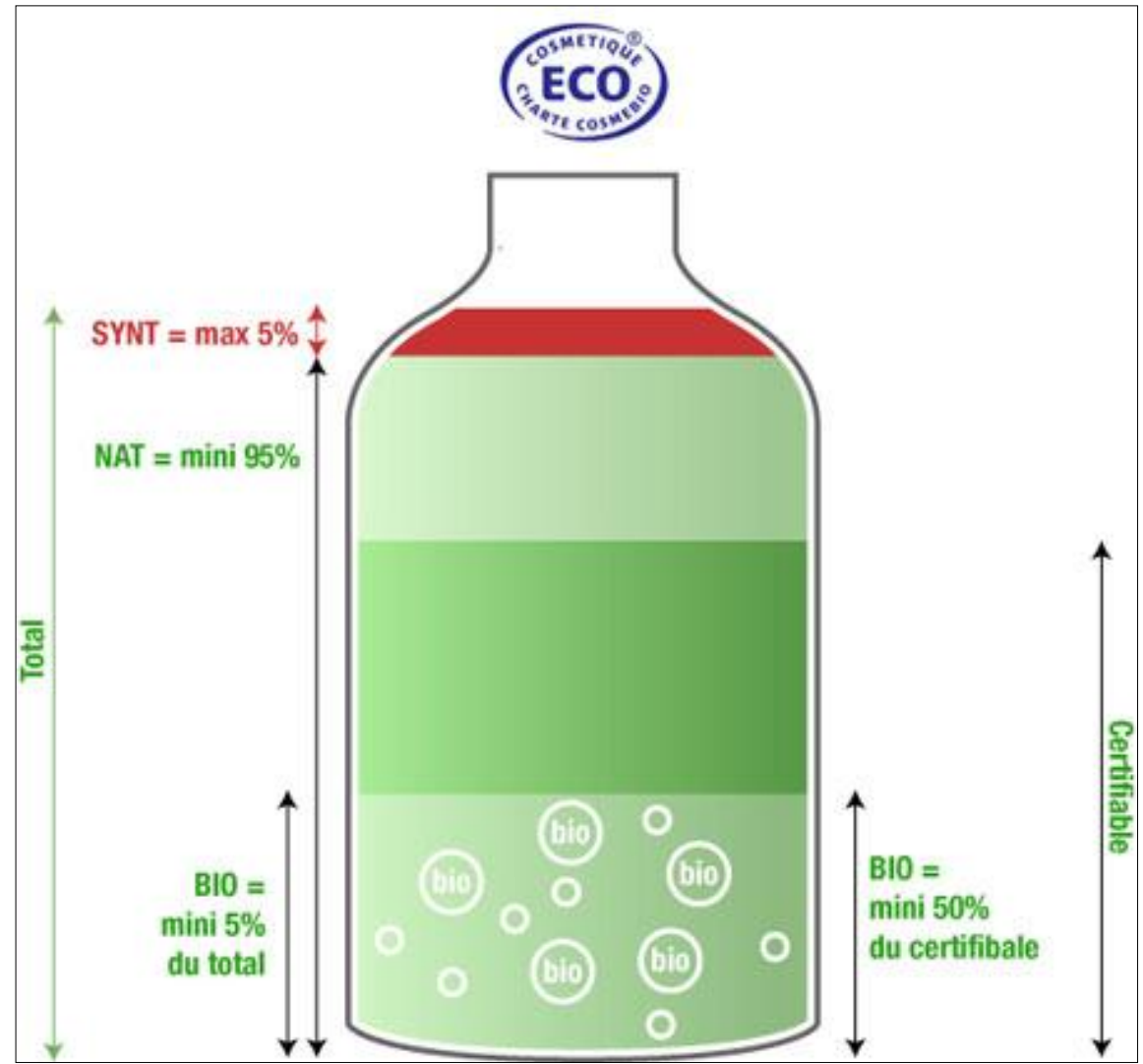

Fonte: COSMEBIO, 2011.

Conforme apontado, o panorama mundial sobre a certificação e selos de origem e qualidade das matérias-primas indica um crescimento do número de agências internacionais autorizadas no monitoramento e avaliação dos produtos (Comissão Europeia para a Agricultura e o Desenvolvimento Rural, 2009), e nesse mesmo caminho, algumas indústrias fabricantes de insumos e produtos finais também têm criado selos próprios, o que acaba criando ainda mais dificuldades para o consumidor avaliar os produtos, afetando diretamente na sua a credibilidade. Como os diversos mecanismos de controle e rastreamento das matérias-primas não têm uma padronização técnica do que 
seria um 'produto natural', foram criados órgãos para desenvolver maior uniformidade sobre os ativos naturais e orgânicos, como a Natural Organic Programme (NOP), nos EUA, e a Cosmos e NaTrue, na Europa.

No Brasil, por exemplo, o Instituto Biodinâmico (IBD) e o Imaflora são as principais entidades credenciadas para o acompanhamento e a liberação dos "selos-verdes" de origem das espécies e dos extratos utilizados na fabricação de produtos cosméticos, entre outros. Ainda no caso brasileiro, destaque deve ser dado para as médias e grandes empresas que desenvolvem insumos e produtos acabados com base na biodiversidade amazônica, atingindo desse modo os critérios de exportação dos principais mercados mundiais. 


\section{CONSIDERAÇÕES FINAIS}

A presente tese de doutorado procurou conhecer e analisar o uso da biodiversidade na indústria de cosméticos e os principais processos de sua cadeia produtiva, desde a produção das matérias-primas, insumos e produtos acabados, as experiências do setor produtivo no que diz respeito à inovação de processos e produtos derivados de ativos naturais, além dos seus aspectos convencionais relevantes à competitividade do setor, dentre eles, mercado, diferenciação de produtos, marketing, obtenção das licenças exigidas pelos órgãos reguladores, entre outros, e buscou, também, espacializar os conjuntos mais significativos desses processos produtivos em curso.

Nas últimas décadas, a indústria de cosméticos tem demonstrado que é um dos setores mais competitivos da indústria contemporânea em geral. A expansão dos mercados de consumo mundial e a crescente demanda por produtos de higiene, perfumes e cosméticos têm impactado diretamente a dinâmica desse setor industrial, refletindo, dentre outros fatores, na formação de novos nichos de mercado e no lançamento constante de novos produtos cada vez mais sofisticados, diferenciados e inovadores. Dentre as tendências, os ingredientes baseados em novas tecnologias e derivados da biodiversidade ganham posição de destaque nesse setor.

O quadro mundial da indústria de cosméticos indica que o setor encontra-se centralizado especialmente nos EUA e na França e a geografia do comércio global de cosméticos e dos demais produtos assinala que essa dinâmica também é fortemente regionalizada. Os EUA e a Europa, particularmente a França e Alemanha, não são somente os principais 
exportadores desses produtos, como também importadores de expressão tanto de insumos como de produtos acabados. Sob esses aspectos, o Brasil também se destaca quanto à presença de indústrias protagonistas neste setor e tem apresentado crescente participação no comércio mundial. Contudo, essas potencialidades em curso não podem ser superestimadas, isto é, apesar da posição de destaque no mercado de consumo mundial (o terceiro maior do mundo), a participação do Brasil nos fluxos de comércio internacional ainda está restrita ao mercado sul americano e distante do volume total daquela observada na Europa, EUA e Japão. Outra característica marcante diz respeito ao padrão de exportação brasileiro que está voltado basicamente na distribuição de matérias-primas e insumos (brutos ou semiprocessados) de baixo valor agregado no mercado.

Dentre as indústrias que comercializam produtos com ativos naturais, novamente destaca-se o grupo de indústrias francesas e norte-americanas, evidenciando o domínio das grandes empresas transnacionais e da evidente concentração de capitais também nesse estratégico segmento. De todo modo, também merece destaque especial a maior indústria de cosméticos brasileira, que é uma das precursoras do segmento no país.

Em um ambiente de intensa competição internacional, a incorporação de novos insumos e princípios ativos, especialmente daqueles inspirados na biodiversidade e desenvolvidos sob a óptica de processos industriais menos impactantes ao meio ambiente, traz para a indústria de cosméticos novos desafios nesse estratégico mercado de bioprodutos. O primeiro deles envolve as atividades de Pesquisa \& Desenvolvimento \& Inovação (PD\&l) sobre novos ingredientes obtidos a partir de extratos vegetais, óleos essenciais e vegetais, 
corantes naturais, plantas medicinais, resinas e manteigas. Nesse setor industrial, a inovação tecnológica tem sido um dos elementos essenciais nesses novos modelos de produção, nos quais seus produtos e processos demandam complexos e extensivos estudos quanto a sua seguridade, estabilidade e eficácia, grande esforço de P\&D e agregação de valor, promovendo importante papel na substituição de diversos insumos nos portfólios das empresas e, assim, renovando os produtos com novos princípios ativos.

Essas modernizações têm sido comandadas, novamente, pelas indústrias líderes de capital transnacional e são visivelmente destacadas na incorporação de inovação e agregação de valor aos insumos, produtos finais e processos altamente avançados (nanotecnologias, por exemplo). Por esses motivos, esse grupo concentra as principais variáveis para assegurar todas as etapas decisivas das atividades industriais e comerciais, tais como os ensaios laboratoriais, as redes de pesquisa com os principais centros, institutos e laboratórios mundiais de pesquisas de ponta além dos recursos para as atividades internas em P\&D, como também dos registros, das certificações e do requerimento de patentes de produtos e/ou processos. Além do mais, a grande indústria demonstra um grande poder organizacional e de logística de produção, comércio, distribuição e circulação dos fluxos e produtos, revelando grande potencial de expansão geográfica nos territórios onde atua.

Apesar do vigor das atividades de pesquisa, o segmento de produtos naturais demanda desafios ainda maiores, considerando que as informações sobre os reais benefícios do uso de ativos naturais em cosméticos ainda são imprecisos quanto suas comprovações de eficácia, segurança, estabilidade, 
entre outros. Esse especializado segmento dos produtos naturais e orgânicos encontra no setor alimentício a sua maior forma de expressão, ocorrendo paralelamente uma transferência desse tipo de mercado também para o setor de cosméticos. Entretanto, o que se observa na indústria de cosméticos é a valorização de um 'conceito', tendo em vista que não existem estudos comprobatórios nessa área que assegurem a maior eficácia dos biocosméticos frente aos produtos semi-sintéticos ou convencionais.

De todo modo, as bioindústrias de cosméticos representam uma inovação enquanto atividades específicas de aproveitamento da biodiversidade e introduzem para o segmento em geral processos de modernização e formas alternativas de uso dos recursos naturais. Sobressai assim um conjunto de mudanças recentes que revela não apenas uma escala mais ampliada dessa cadeia produtiva, como também uma diversificação dos locais de produção de matérias-primas e a distribuição de insumos diferenciados ligados ao segmento de cosméticos derivados de ativos naturais.

No Brasil, o setor de cosméticos é representado em sua maioria por indústrias de pequeno e médio porte instaladas, sobretudo no estado de São Paulo, lócus de maior representatividade das empresas do setor no país. De um lado, destaca-se um seleto grupo de grandes indústrias nacionais que possui liderança no mercado nacional e forte atuação no mercado regional, possuindo também alta capacidade inovativa e de atividade em P\&D. Já as pequenas indústrias não dispõem de capacidade tecnológica e inovação suficiente para disputar com as líderes e, assim, os obstáculos são muito maiores e mais complexos. Diante disso, as pequenas indústrias se tornam fortemente dependentes dos intermediários e produtores de insumos, e que 
geralmente fornecem ingredientes com menor poder de inovação devido aos altos cultos dos ativos para essas pequenas empresas. De modo geral, essas indústrias poderiam ser caracterizadas como "misturadoras". Além do mais, observam-se profundas diferenças no grau de desenvolvimento tecnológico e a forte dependência externa de insumos inovadores, concentrados nos países dos principais players globais do setor.

Dentre outros resultados, este trabalho nos permitiu identificar que os sistemas produtivos na região Amazônica estabelecem atualmente conexões interindustriais diversas, incluindo os segmentos ali localizados e de fora dela. Entretanto, esses processos ainda permanecem de certo modo restritos e limitados, sobretudo para os pequenos empreendimentos regionais. Isto porque "eles mantêm basicamente um padrão espacial tendente à concentração que decorre, sobretudo, da sua alta dependência da disponibilidade de infraestruturas convencionais (estradas, energia, etc.) e novas (infovias, por exemplo), além da densidade da rede de cidades e da qualidade dos equipamentos e dos serviços dos centros urbanos, favorecendo desse modo as capitais dos estados e, especialmente Belém e Manaus com as suas respectivas redes" (COSTA, W. M., 2009, p. 27).

Ademais, as grandes empresas (nacionais e internacionais) também comandam esses sistemas produtivos e apesar dos avanços recentes nos processos de cultivo e coleta das matérias-primas, as limitações vinculadas à sazonalidade e regularidade da produção também são vistas como barreiras no fomento dessas cadeias produtivas por parte da grande indústria. Outro aspecto diz respeito aos pequenos produtores familiares, que de um lado têm se articulado a esses sistemas produtivos, porém essas conexões ainda têm se 
mostrado insuficientes, mantendo diversas "comunidades à margem da core area dessa modernização" (COSTA, W. M, 2009).

No que se refere a regulamentação do setor, as severas regras para a normatização dos produtos com ativos vegetais têm promovido por sua vez uma "elitização" do segmento. Cada vez mais os padrões adotados internacionalmente obrigam as empresas de todo mundo e do Brasil a se adequarem e internalizarem em seus processos produtivos diversos procedimentos técnicos para a aprovação e o licenciamento dos produtos. Portanto, a atuação da indústria nacional visando introduzir e consolidar os padrões de produção sob novas bases tecnológicas tem procurado operar mediante um olhar mais atento para o que ocorre nos mercados de consumo internacionais, o que de certa forma tem se tornado uma barreira para as pequenas indústrias (COSTA, W. M., 2007).

Diante do exposto, um dos pontos centrais desta tese que nos desperta a atenção, diz respeito aos principais desafios e esforços que o Brasil deverá enfrentar para alcançar os novos patamares tecnológicos e de competição comercial vigentes atualmente no mercado internacional. Como vimos nesta pesquisa, apesar de possuir um enorme mercado consumidor, um avançado parque industrial, um sofisticado sistema de pesquisa e acesso à floresta tropical mais rica e biodiversa do mundo (sem contar os demais ecossistemas), - Brasil ainda continua dependente da importação de diversos insumos que são incorporados ao longo da cadeia produtiva que envolve a indústria de cosméticos.

Por fim, a nossa expectativa é que este trabalho contribua para o avanço dos conhecimentos em geografia neste novo campo que agora passa a ser 
tomado enquanto um promissor segmento industrial contemporâneo. Esperamos que ele contribua, especialmente, com a geografia econômica dedicada às transformações atuais da indústria contemporânea baseada na inovação de produtos e processos e ainda com as teorias que têm incorporado o debate ambiental aos temas da geografia em geral. 


\section{BIBLIOGRAFIA}

ABC. Associação Brasileira de Cosmetologia. Disponível em: www.abccosmetologia.org.br/. Acesso em dezembro de 2011.

ABIHPEC. Panorama do Setor: Higiene Pessoal, Perfumaria e Cosméticos. São Paulo: ABIHPEC, Relatórios (2008 a 2012).

ABDI. Agência Brasileira de Desenvolvimento Industrial. Disponível em: www.abdi.com.br/. Acesso em março de 2011.

ACAD. Associação de Academias. Disponível em: www.acadbrasil.com.br. Acesso em março de 2012.

ADS. Agência de Desenvolvimento Sustentável do Amazonas (2011). Disponível em: www.ads.am.gov. Acesso em março de 2012.

AGRESTE. La statistique, l'évaluation et la prospective agricole. Rapport de Provence-Alpes-Côte d'Azur. Étude n 51 - avril 2010.

ALBAGLI, S. Geopolítica da Biodiversidade. Brasília: IBAMA, 1998a.

. Da Biodiversidade à biotecnologia: a nova fronteira da informação. Ci. Inf., Brasília: v.27, n.1, p-7-10, jan/abr de 1988b.

; BRITTO, J. Glossário de arranjos produtivos locais. In.: Arranjos Produtivos Locais: uma nova estratégia de ação para o SEBRAE. Rio de Janeiro: UFRJ/Redesist, Dezembro 2002.

ALCALDE, M. T. Cosmética natural y ecológica: regulación y clasificación. vol. 27, no 9, Barcelona: OFFARM, 2008. 
ALMEIDA, HAMILTON DE. Óleos amazônicos conquistam o mundo: indústria oleoquímica trabalha a todo vapor para atender interesse mundial por essências da floresta brasileira. Química e Derivados. Edição no 429 , agosto de 2004 .

ALVES, O. L. Regulamentação da nanotecnologia ganha estudo no Brasil. Entrevista CBN, em 09 de janeiro de 2012. Disponível em: cbn.globoradio.globo.com/programas/cbn-total/2012/01/09/. Acesso em setembro de 2012.

AMAZON SECRETS. Homepage institucional. Disponível em: www.amazonsecrets.com.br/ . Acesso em agosto de 2011.

APEX. Agência Brasileira de Promoção de Exportações e Investimentos. Disponível em: www.apexbrasil.com.br/. Acesso em novembro de 2010.

ANTAS JR, R. M. O Consumo contemporâneo no território brasileiro. In: DOWBOR, L.; SILVA, H; E.; ANTAS JR, R. M (orgs). Desafios do Consumo. Petrópolis: Vozes, 2007.

ANVISA. Agência Nacional de Vigilância Sanitária. Disponível em: www.anvisa.gov.br/ . Acesso em agosto de 2011.

. Quando a busca pela beleza impõe riscos à saúde. In. Boletim Informativo ANVISA, ed. 66, janeiro de 2007.

ANPEI. Associação Nacional de Pesquisa, Desenvolvimento e Engenharia das Empresas Inovadoras. Disponível em: www.anpei.org.br/ . Acesso em novembro de 2011.

ANPROTEC. Associação Nacional de Entidades Promotoras de Empreendimentos Inovadores. Disponível em: www.anprotec.org.br/ . Acesso em novembro de 2011. 
ARIĖS, P.; DUBY, G. Historia da Vida Privada, 2: da Europa Feudal à Renascença. Organização: Georges Duby, Tradução: Maria Lúcia Machado, São Paulo: Companhia das Letras, 2009.

ACAD. ASSOCIAÇÃO BRASILEIRA DE ACADEMIAS. Disponível em: www.acadbrasil.com.br. Acesso em junho de 2012.

AUBERTIN, CATHERINE; VIVIEN, FRANCK-DOMINIQUEE (direction). Le development durable: enjeux politiques, économiques et sociaux. Nouvelle Édition, Paris: La Documentation Française, 2010.

AVON. Homepage institucional. Disponível em: www.br.avon.com/ . Acesso em janeiro de 2011.

BALICK, M.J.; ELISABETSKY, E.; LAIRD, S.A. (Ed.). Medicinal Resources of the Tropical Forest: biodiversity and its importance to human health. New York: Columbia University Press, 1996.

BARROS, G. Ibama aplica multa milionária a empresa de vice de Marina por uso não autorizado de conhecimento genético. Notícias. Portal IG, Economia, 12 de novembro de 2010. Disponível em: http://colunistas.ig.com.br/guilhermebarros/2010/11/12/ibama-aplica-multa-milionaria-aempresa-de-vice-de-marina-por-uso-nao-autorizado-de-conhecimento-genetico/?allcomments Acesso em novembro de 2010.

BASF. Disponível em: www.basf.com.br. Acesso em: janeiro de 2012.

BAUDRILLARD, J. A Sociedade de Consumo. Tradução de Artur Morão, $2^{\underline{a}}$ ed., Lisboa: Edições 70, 2007.

BAUMAN, Zygmunt. Vida para consumo: a transformação das pessoas em mercadoria. Tradução Carlos Alberto Medeiros, Rio de Janeiro: Zahar, 2008. 
BAURES, C. et al. Les cosmétiques biologiques à la loupe "Entrez dans l'univers des controverses actuelles, des labels et de la réglementation. Mastère Management des Industries de Santé Dossier Santé, ESC Toulouse, Juin 2009.

BECK, U. La société du risque: sur la voie d'une autre modernité. Paris: Éditions Flammarion, (1986), 2008.

BENKO, G. Economia, espaço e globalização na aurora do século XXI. São Paulo: Hucitec, 1999.

BECKER, B. K. Amazônia: geopolítica na virada do III milênio. Rio de Janeiro: Garamond, 2004.

. Uma visão de futuro para o coração da florestal da Amazônia. In.: Um Projeto para a Amazônia no século 21: desafios e contribuições, Brasília, DF: CGEE, 2009.

BERACA. Homepage institucional. Disponível em: www.beraca.com.br/ . Acesso em agosto de 2011.

BIANCO, A. L. A Construção das Alegações de Saúde para Alimentos Funcionais. Texto para Discussão 28, Embrapa Informação Tecnológica Brasília, DF, 2008.

BIS. Department for Business Innovation \& Slills. The 2010 R\&D Scoreboard. The Top 1.000 UK and 1.000 Global Companies by R\&D Investiment. Disponível em: www.innovation.gov.uk/rd scoreboard. Acesso em maio de 2011.

CAMARONO, A. A. Envelhecimento da população brasileira: uma contribuição demográfica. Texto para Discussão № 858 , IPEA, Rio de Janeiro, 2002. 
CAMTA. COOPERATIVA AGRÍCOLA MISTA DE TOMÉ-AÇU (2012). Disponível em: www.camta.com.br. Acesso em março de 2012 .

CAPANEMA, L. X. L.; VelASCO, L. O. M.; FILHO, P. L. P.; NOGUTI, M. B. Panorama da Indústria de Higiene Pessoal, Perfumaria e Cosméticos. Rio de Janeiro: BNDES Setorial, n. 25, p. 131-156, mar., 2007.

CASTELLS, M. A Sociedade em Rede. A Era da Informação: economia, sociedade e cultura, v.1, 6ª edição, São Paulo: Paz e Terra, 1999.

. O Poder da Identidade. A Era da Informação: economia, sociedade e cultura, v.2, 6ª edição, São Paulo: Paz e Terra, 1999.

CASTILLO, R.; FREDERICO, S. Espaço geográfico, produção e movimento: uma reflexão sobre o conceito de circuito espacial produtivo. Sociedade \& Natureza, Uberlândia, 22 (3): 461-474, dez, 2010.

CASTRO, ANTONIO MARIA GOMES DE; LIMA, SUZANA MARIA VALLE; GOEDERT, WENCESLAU J. [et all.] (Ed.). Cadeias Produtivas e Sistemas Naturais: prospecção tecnológica. Brasília: EMBRAPA-SPI/EMBRAPA-DPD, 1998.

CASTRO, Ana Lúcia de Castro. Culto ao corpo e sociedade: mídia, cultura de consumo e estilos de vida. Tese (Doutorado em Sociologia) - Instituto de Filosofia e Ciências Humanas, Universidade Estadual de Campinas, Campinas, 2001.

CENTRO FLORA. Homepage institucional. Disponível em: www.centroflora.com.brl. Acesso em agosto de 2011.

CETIC. Centro de Estudos sobre as Tecnologias da Informação e da Comunicação. Disponível em: www.cetic.br. Acesso em outubro de 2012. 
CGEE. Avaliação de Políticas de Ciência Tecnologia e Inovação. Diálogo entre Experiências Internacionais e Brasileiras. Brasília: Centro de Gestão e Estudos Estratégicos, 2008.

CGEN. Conselho de Gestão do Patrimônio Genético. Disponível em: www.mma.gov.br/port/cgen. Acesso em abril de 2012.

CGI. Centre for the Promotion of Imports from Developing Countries. EU MARKET SURVEY 2005: Natural ingredients for cosmetics. Report CGI, 2005.

CHÁVEZ, M. G. G. Uma Era da Biodiversidade: ambiente, reflexividade e sociedade cosmética. Quilmes: Revista Theomai, número especial, Universidad Nacional de Quilmes/Buenos Aires, Argentina, 2004.

CIHEF. Comité Interprofessionnel des Huiles Essentielles Françaises. Lavandins et Lavandes: Plantes aromatiques. Production et marche. Perspectives. Rapport, 2008.

CMMAD. Comissão Mundial para o Meio Ambiente e Desenvolvimento. Nosso Futuro Comum. Rio de Janeiro: Fundação Getúlio Vargas, 1988.

COMISSÃO EUROPEIA PARA A AGRICULTURA E O DESENVOLVIMENTO RURAL (2009). Disponível em:ec.europa.eu/agriculture . Acesso em agosto de 2011.

COMTRADE. UN COMTRADE. UNITED NATIONS STATISTICS DIVISION. United Nations Commodity Trade. Disponível em: unstats.un.org/unsd/default.htm. Acesso em abril de 2011.

CONTEL, F. B. Território e Finanças: técnicas, normas e topologias bancárias no Brasil. Tese (Doutorado em Geografia) - Faculdade de Filosofia, Letras e Ciências Humanas, Universidade de São Paulo, São Paulo, 2006. 
COOPFRUT. COOPERATIVA AGROINDUSTRIAL DE TRABALHADORES E PRODUTORES RURAIS DE IGUARAPÉ-MIRI. In. Bolsa Amazônia. Dispon'vel em: www.bolsaamazonia.be. Acesso em março de 2012.

COOPERACRE. COOPERATIVA CENTRAL DE COMERCIALIZAÇÃO EXTRATIVISTA DO ACRE (2012). Disponível em: www.cooperacre.com. Acesso em março de 2012.

CORDER, S. Políticas de Inovação Tecnológica no Brasil: experiência recente e perspectivas. Texto para discussão IPEA n.ำ1244, Brasília, 2006.

CORREIA, R. L. Região e organização espacial. $7^{\text {ạ }}$ ed. São Paulo: Editora Ática, 2000.

COSSMA. Beauty and Personal Care: Euromonitor from trade sources/national statistics. COSSMA, issue 9/2011, page 10.

COSMETICS \& TOILETRIES. Study Reports Need for More Cosmeceutical Ingredients. Cosmetics \& Toiletries, 4 de novembro de 2009. Disponível em:www.cosmeticsandtoiletries.com/formulating/category/antiaging/69080622.html. Acesso em abril de 2012.

Doses de saúde e beleza. In. Cosmetics \& Toiletries (edição em português), vol. 23, set-out de 2011. Dispon'vel em: wwwcosmeticsonline.com.br. Acesso em abril de 2012.

COSTA, WANDERLEY MESSIAS DA. Utilização de Produtos Florestais Não-Madeireiros com ênfase nas Organizações Comunitárias e nos Sistemas Produtivos Emergentes relacionados à Bioindústria. In: Um Projeto para a Amazônia no século 21: desafios e contribuições, Brasília, DF: CGEE, 2009. 
Tendências Recentes na

Amazônia: os sistemas produtivos emergentes. In: Dimensões Humanas do Experimento de Grande Escala da Biosfera-Atmosfera da Amazônia. Coleção Ciência Ambiental, São Paulo: Edusp, 2007.

CRODA. Homepage institucional. Disponível em: www.croda.com.br/. Acesso em agosto de 2011.

DEBERT, G. G. A reinvenção da velhice. São Paulo: EDUSP-FAPESP, 1999.

DEFELICE, S. L. The nutraceutical revolution: its impact on food industry R\&D. In.: Trends in Food Science \& Technology, v. 6, p. 59-61, 1995.

DEPARTMENT FOR BUSINESS INNOVATION \& SKILLS. The 2010 R\&D Scoreboard. Report, november 2010.

DI MĖO, GUY M. L'industrie française de la parfumerie. In: Annales de Géographie. 1973, t. 82, n452. pp. 454-476.

DIAS, R. Marketing Ambiental: ética, responsabilidade social e competitividade nos negócios. São Paulo: Atlas, 2007.

DICKEN, P. Mudança Global: mapeando as novas fronteiras da economia mundial. Porto Alegre: Bookman, 2010.

DINATO, M. R. Produção e Consumo Sustentáveis: o caso da Natura Cosméticos S.A.. Tese (Doutorado em Administração), Faculdade de Administração, Universidade Federal do Rio Grande do Sul, Porto Alegre, 2006.

DONAIRE, D. Gestão Ambiental nas Empresas. São Paulo: Atlas, 1995. 
DUARTE, O. ; VELHO, Lea. La bioprospección como un mecanismo de cooperación internacional para fortalecimiento de capacidades en ciencia y tecnología en Colombia. Ciência da Informação (Impresso) 38, p. 96-110, 2009.

DROULERS, MARTINE. Brésil: une géohistoire. Paris: Presses Universitaires de France, 2001.

DWECK, R. H. A beleza como variável econômica: reflexo nos mercados de trabalho e de bens e serviços. Texto para discussão IPEA n.ำ 618, Rio de Janeiro, 1999.

ECO, U. A História da Beleza. Tradução Eliana Aguiar. Rio de Janeiro: Record, 2004.

ECOCERT. Disponível em: www.ecocert.com.br. Acesso em julho de 2011.

EMBRAPA. Empresa Brasileira de Pesquisa Agropecuária. Disponível em: www.embrapa.br/ . Acesso em abril de 2011.

EUROMONITOR. Euromonitor Internacional: business inteligence, company profiles, strategic market analysis. Disponível em: www.euromonitor.com. Acesso em julho de 2012.

EUROSTAT. Statistical Office of the European Communities. Disponível em: www.ec.europa.eu/eurostat . Acesso em abril de 2011.

FARMAERVAS. Homepage institucional. Disponível em: www.farmaervas.com.br/. Acesso em agosto de 2011.

FDA. Food and Drug Administration. Disponível em: www.fda.gov. Acesso em dezembro de 2010. 
FEATHERSTONE, M. O curso da vida: corpo, cultura e imagens do processo de envelhecimento. In: DEBERT. G.G. Antropologia e velhice. Textos Didáticos IFCH/UNICAMP,1993.

FEBRAFARMA. Federação Brasileira da Indústria Farmacêutica. Disponível em: www.febrafarma.org.br . Acesso em agosto de 2010.

FECOMERCIOSP. FEDERAÇÃO DO COMÉRCIO DO ESTADO DE SÃO PAULO. Disponível em: em: www.fecomercio.com.br. Acesso em: junho de 2011.

FERREIRA, M. E.; FALEIRO, F. G. Biotecnologia: avanços e aplicações no melhoramento genético vegetal. In: FALEIRO, G. F.; NETO, A. L. de F. (ed. téc). Savanas: desafios e estratégias para o equilíbrio entre sociedade, agronegócio e recursos naturais, Simpósio, Capítulo 23, p. 765-792, Planaltina, DF: EMBRAPA Cerrados, 2008.

FERRO, A. F. P. ; BONACELLI, M. B. M.; ASSAD, A. L. D. A Exploração da Biodiversidade Brasileira pela Indústria de Cosméticos Nacional. Campinas: Departamento de Política Científica e Tecnológica - DPCT/IG Unicamp, 2004.

FERRO, A. F. P. Gestão da Inovação Aberta: praticas e competências em P\&D colaborativa. Tese (Doutorado em Política Científica e Tecnológica) Instituto de Geociências, UNICAMP, Campinas, 2010.

FILHO, P. L. P.; CAPANEMA, L. X. L. A Indústria farmacêutica nacional: desafios rumos à inserção global. In.: ALÉM, A. C.; GIAMBIAGI, F. (orgs.). O BNDES em um Brasil em Transição. BNDES, Rio de Janeiro, junho de 2010.

FORUM AMAZÔNIA SUSTENTÁVEL. Protocolo de Nagoya não será retroativo, garante especialista. Entrevista publicada em 11 de outubro de 2012. Disponível em: www.forumamazoniasustentavel. Acesso em outubro de 2012. 
FORTES, M. Desenvolvimento e meio ambiente: a visão empresarial. In.: Velloso, J. P. (org.). A ecologia e o novo padrão de desenvolvimento no Brasil. São Paulo: Nobel, 1992.

GALEMBECK, F.; CSORDAS,Y. Cosméticos: a química da beleza (2009). Disponível em: web.ccead.pucrio.br/condigital. Acesso em abril de 2011.

GARCIA, R.; FURTADO, J. Estudo da competitividade de cadeias integradas no Brasil: impactos das zonas de livre comércio. UNICAMP-IENEIT, Campinas, 2002.

; SALOMAO, S. Relatório Final Setorial: cosméticos. Rede DDP - Diretório da Pesquisa Privada; FINEP, MCT: Brasília, Jan/2008.

. Internacionalização Comercial e Produtiva na Indústria de Cosméticos: desafios competitivos para empresas brasileiras. Rev. Produção, São Paulo, v. 15, n. 2, p. 158-171, 2005.

GOTTLIEB, O. e KAPLAN, M.A. Das Plantas Medicinais aos Fármacos Naturais. Rio de Janeiro: Ciência Hoje, vol. 15, nº 89, p.51-54, 1993.

GUERVEN, ESTELLE. Biocosmétiques: la puissance de la Nature au coeur de la beauté. Paris: Guy Trédaniel Éditeur, 2008.

GUIMARÃES, E. A. Políticas de Inovação: financiamentos e incentivos. IPEA, Texto para Discussão nำ 1212, Brasília, agosto de 2006.

HASENCLEVER, L.; ZISSIMOS, I. A evolução das configurações produtivas locais no Brasil: uma revisão da literatura. Estudos Econômicos, 36(3): 407433, São Paulo: jul-set de 2006. 
IBGE. Instituto Brasileiro de Geografia e Estatística. Disponível em: www.ibge.org.br/. Acesso em abril de 2012.

INSEE. Institut national de la statistique et des études économiques France. Disponível em: www.insee.fr. Acesso em janeiro de 2012.

ISAPS. International Society of Aesthetic Plastic Surgery. Disponível em: www.isaps.org. Acesso em abril de 2012.

ITC. International Trade Center. Disponível em: www.intracen.org/. Acesso em abril de 2011.

JONES, A. e DUERBECK, K. Natural ingredients for cosmetics. EU Market Survey - 2004. Centre for the Promotion of Imports from developing countries (CBI). Setembro, 2004.

JUNIOR, N.L.S. Desafios da Bioprospecção. Texto para Discussão: n. 1569, Brasília: IPEA, janeiro de 2011.

JÚNIOR, R. Natura quer firmar a marca na Europa com loja em Paris. São Paulo: O Estado de São Paulo, 24 de abril de 2005.

KLIGMAN, A. M. Cosmecêuticos: a terceira categoria. Revista Cosmetics \& Toiletries (edição em português), vol. 14, jul-ago de 2002.

KLINE \& COMPANY. Nutricosmetics: decoding the convergence of beauty and healthcare. Report In-Cosmetics, Amsterdam, 2008.

Sparked by Innovation, Fueled by Consumption: Emerging Ingredients Trends. Report In-Cosmetics, Milan, 2011.

L'ACQUA DI FIORI. Homepage institucional. Disponível em: www.lacquadifiori.com.br/. Acesso em agosto de 2011. 
L'OCCITANE EN PROVENCE. Homepage institucional. Disponível em: www.fr1.loccitane.com/. Acesso em abril de 2012.

L'OREAL. Homepage institucional. Disponível em: www.loreal.com/. Acesso em março de 2012.

LAYRARGUES, P. P. Sistemas de Gerenciamento Ambiental, Tecnologia Limpa e Consumidor Verde: a delicada relação empresa-meio ambiente no ecocapitalismo. Revista de Administração de Empresas - ERA, v. 40, ㄲo2, São Paulo, abr/jun 2000.

LEFF, E. Ecologia, Capital e Cultura: racionalidade ambiental, democracia participativa e desenvolvimento sustentável. Tradução de Jorge Esteves da Sila, Blumenau: FURB, 2000.

LEIS, H. R. A Modernidade Insustentável: as críticas do ambientalismo à sociedade contemporânea. Petrópolis: Vozes e Floranópolis: UFSC, 1999.

LENNARD, C. A Look at Global Anti-Ageing Drivers and Hinderes. InCosmetics, 2009. Disponível em: www.in-cosmetics.com. Acesso em abril de 2012.

LIPOVETSKY, G. O império do efêmero: a moda e o seu destino nas sociedades modernas. Tradução de Maria Lúcia Machado. São Paulo: Companhia das Letras, 1989.

A terceira mulher: permanência e revolução do feminino. São Paulo: Companhia das Letras, 2000.

A felicidade paradoxal: ensaio sobre a sociedade de hiperconsumo. Tradução Maria Lucia Machado. São Paulo: Cia. das Letras, 2007. 
LUCENA, R. Antropóloga explica por que as pessoas compram mais cosméticos na recessão. Coluna Equilíbrio e Saúde, Folha de São Paulo, 21 de agosto de 2012 Disponível em: http://www1.folha.uol.com.br/equilibrioesaude/1140155-antropologa-explicapor-que-as-pessoas-compram-mais-cosmeticos-na-recessao.shtml. Acesso em agosto de 2012.

MAFFESOLI, M. No fundo das Aparências. Tradução de Bertha Halpern Gurovitz, Petropolis: Vozes, 1996.

MCT. Ministério de Ciência e Tecnologia. Disponível em: www.mct.gov.br Acesso em maio de 2012.

MDIC. Ministério do Desenvolvimento, Indústria e Comércio Exterior. Disponível em: www.desenvolvimento.gov.br/. Acesso em abril de 2011.

MELLAGE, C. Nutricosmetics, decoding the convergence of beauty and healthcare. In Cosmetics, Amsterdam, 2008. Disponível em: www.klinegroup.com/news/speeches/Nutricosmetics-apr08.pdf. Acesso em: abril de 2012.

MELO, C. P; PIMENTA, M. Nanociências e nanotecnologias In. Parcerias Estratégicas, no 18, Brasília, DF, agosto de 2004.

MIYATA, H. Trabalho, Redes e Territórios nos Circuitos da Economia Urbana: uma análise da venda direta em Jundiaí e Região Metropolitana de São Paulo. Tese (Doutorado em Geografia) - Faculdade de Filosofia, Letras e Ciências Humanas, Universidade de São Paulo, São Paulo, 2011.

MIGUEL, L. M. Uso Sustentável da Biodiversidade Amazônica: experiências atuais e perspectivas das indústrias de cosméticos e fitoterápicos. Dissertação (Mestrado em Geografia), Faculdade de Filosofia, Letras e Ciências Humanas, Universidade de São Paulo, São Paulo, 2007. 
MMA. MINISTÉRIO DO MEIO AMBIENTE; SUFRAMA. SUPERINTENDÊNCIA DA ZONA FRANCA DE MANAUS; SEBRAE. SERVIÇO BRASILEIRO DE APOIO ÀS MICRO E PEQUENAS EMPRESAS. GTA. GRUPO DE TRABALHO AMAZÔNICO. Produtos Potenciais da Amazônia. Relatório Técnico, Brasília: MMA, 1998.

. Disponível em: www.mma.gov.br.

Acesso em março de 2012.

MORAES, A. C. R.; COSTA, W. M. da. Geografia Crítica: a valorização do espaço. 2ª . ed. São Paulo: Hucitec, 1987.

MORAES, A. C. R. Meio Ambiente e Ciências Humanas. São Paulo: Hucitec, 1994.

MORETTI, C.; AUBERTIN, C. Stratégies des firmes pharmaceutiques: la bioprospection em question. In.: Les marchés de la biodiversité. Paris: IRD, 2008.

MORRIS, G. Mega mergers ahead for downstream brand owners? Incosmetics, 21 de julho de 2009.

MULLER, MANUEL RUIZ. Sistema de Informação sobre Biodiversidade/Biotecnologia para o Desenvolvimento Sustentável: aspectos legais sobre 0 acesso a recursos genéticos nas Américas. Programa de Assuntos Internacionales. Sociedad Peruana de Derecho Ambiental, Lima, 1998.

MULON, LAURENCE. Cosmétique « bio »...Projecteurs sur le cosmétique naturel et bio. Dossier, Septembre/Octobre, 2010.

NASRI, F. O envelhecimento populacional no Brasil. In: Demografia e epidemiologia do envelhecimento. Einstein, 6 (Supl 1):S4-S6, 2008. 
NATURA. Homepage institucional. Disponível em: www.natura.net/port/index.asp. Acesso em maio de 2012.

NERI, M. C. Consumidores, produtores e a nova classe média: miséria, desigualdade e determinantes das classes. Rio de Janeiro: FGV/IBRE, CPS, 2009.

OLIVEIRA, D. (2005) Plantas medicinais: legislação é o maior entrave para estudos, afirmam pesquisadores e empresas. Jornal da Ciência, n. 2792, 17 de junho de 2005. Disponível em www.jornaldaciencia.org.br. Acesso em setembro de 2010.

O BOTICÁRIO. Homepage institucional. Disponível em: www.boticario.com.br. Acesso em abril de 2012.

OCDE. Organização de Cooperação e Desenvolvimento Econômico. Disponível em: www.oecd.org. Acesso em janeiro de 2011.

OLIVEIRA, D. (2005) Plantas medicinais: legislação é o maior entrave para estudos, afirmam pesquisadores e empresas. Jornal da Ciência, n. 2792, 17 de junho de 2005. Disponível em www.jornaldaciencia.org.br. Acesso em setembro de 2010.

ONIPPAM. Office National Interprofessionnel des Plantes à Parfum, Aromatiques et Médicinales. Rapport, 2007.

ONU. Programa das Nações Unidas para os Assentamentos Urbanos. Relatório: Estado das Cidades da América Latina e Caribe, 2012.

. United Nations Conference on Sustainable Development. Rio+20. Disponível em: www.uncsd2012.org. Acesso em junho 2012.

ORGANIC MONITOR. Disponível em: www.organicmonitor.com . Acesso em fevereiro de 2011. 
OTTMAN, J. A. Marketing Verde: desafios e oportunidades para a nova era do marketing. Trad. de Marina Nascimento Paro, São Paulo: Makron Books, 994.

OX COSMÉTICOS. Homepage institucional. Disponível em: www.oxcosmeticos.com.br. Acesso em setembro de 2011.

PALACIOS, A. da R. J. As marcas na pele, as marcas no texto: sentidos de tempo, juventude e saúde na publicidade de cosméticos em revistas femininas durante a década de 90. Tese (Doutorado em Comunicação e Cultura Contemporânea), Programa de Pós-Graduação em Comunicação e Cultura Contemporânea, Universidade Federal da Bahia, Bahia, 2004.

As múltiplas idades e os múltiplos usos: cultura, consumo e segmentação de público observados em anúncios publicitários impressos de cosméticos femininos. Texto publicado em Comunicação, Mídia e Consumo, vol. 3, nº 6, ESPM: São Paulo, 2006. Disponível em: <http://bocc.ubi.pt/pag/palacios-annamaria-multiplasidades.pdf>.

PALMA, MARIO SERGIO. Estudo de Tendências dos Mercados Nacional e Internacional para Plantas de Usos Medicinal e Cosmético. Bioamazônia, São Paulo, 2000.

PASS. Disponível em: www.pole-pass.fr. Acesso em dezembro de 2011.

PAVARINI, MARCOS DE FARIA (Coord.). Estudo do Potencial de Mercado de Amostras. Ministério do Meio Ambiente Secretaria de Coordenação da Amazônia PROBEM/Amazônia, BIOAMAZÔNIA, 1999.

PESQUISA FAPESP. Beleza fundamentada: grupo de pesquisadores em conjunto com empresas prepara nanocosméticos com aplicações 
variadas. Texto de Dinorah Ereno. Revista FAPESP, edição impressa 146, São Paulo: abril 2008.

. Beleza retocada: extratos feitos a partir de plantas e ativos nanoencapsulados são tendência entre pequenas empresas brasileiras. Texto de Dinorah Ereno. Revista FAPESP, edição impressa 190, São Paulo: dezembro de 2011.

PITMAN, S. Report suggests nanotechnology will lead to a new personal care category. Cosmetics Design, 13 de julho de 2010.

PLÉ, CAROLINE. Le secteur industriel de la parfumerie. In: Revue de géographie de Lyon. Vol. 73 n¹, 1998.

PORTILHO, M. F. F. O discurso internacional sobre consumo sustentável: possibilidades de politização e ambientalização da esfera privada. Tese (Doutorado em Ciências Sociais) - Instituto de Filosofia e Ciências Humanas, Universidade Estadual de Campinas, Campinas, 2003.

. Consumo sustentável: limites e possibilidade de ambientalização e politização das práticas de consumo. Cadernos EBAPE. Edição Temática 2005. Disponível em: www.scielo.br/pdf/cebape/v3n3/v3n3a05.pdf. Acesso em junho de 2012.

PREFEITURA MUNICIPAL DE DIADEMA. Congresso consolida Diadema como Cidade da Beleza. 02 de junho de 2008. Disponível em: 187.48.63.140/municipio.html?start=3780. Acesso em julho de 2011.

RAIS (IBGE). Anuário Estatístico (2008). Disponível em: tme.gov.br. Acesso em: dezembro de 2011.

RAMALHO, Y. M. M. et al. Biotecnologia: cenário internacional e perspectivas para o Brasil. Rio de Janeiro: BNDES/DEEST, 1990. 
REIS, C. et al. Biotecnologia para saúde no Brasil. BNDES Setorial 32, p. 193-230, 2009.

REVEL, J. Os Usos da Civilidade. In.: ARIÈS, P.; DUBY, G. História da vida privada, 3: da renascença ao século das luzes. Organização: Roger Chartier. Tradução: Hildegard Feist. São Paulo: Companhia das Letras, 2009.

REVILLA, JUAN. Plantas da Amazônia: oportunidades econômicas e sustentáveis. Manaus: Programa de Desenvolvimento Empresarial e Tecnológico, 2000.

RIBEIRO, W. C. A Ordem Ambiental Internacional. São Paulo: Contexto, 2001.

RIFKIN, J. O século da biotecnologia: a valorização e reconstrução do mundo. São Paulo: Makron Books, 1999.

RIOS, M. H. V. Anúncios de cosméticos antissinais: sinais de uma beleza jovem, saudável e atemporal. Dissertação (Mestrado em Comunicação Social) - Programa de Pós-Graduação em Comunicação Social, PUC, Belo Horizonte, 2010.

ROSA, I. L. V. Nanotecnologia e Cosméticos. Centro Multidisciplinar para o Desenvolvimento de Materiais Cerâmicos - CMDMC / CEPID - FAPESP, 2006. Disponível em: www.cmdmc.com.br/videos/video. Acesso em abril de 2012.

SACHS, I. Caminhos para o Desenvolvimento Sustentável. Rio de Janeiro: Garamond, 2002.

SANT'ANNA, D. B. É possível realizar uma história do corpo? In: SOARES, C. L. (Org.). Corpo e história. Campinas: Autores Associados, 2.ed. 2004.

SANTOS, M. Metamorfoses do espaço habitado. São Paulo: Hucitec, 1988. 
A Natureza do Espaço: Técnica e Tempo. Razão e Emoção. 4⿳亠丷a ed. - São Paulo: Edusp, 2004a.

O Espaço Dividido: os dois circuitos da economia urbana dos países subdesenvolvidos. Trad. De Myrna T. Rego Viana $-2^{\underline{a}}$ ed., São Paulo: Edusp, 2004b.

SANTOS, THEOTONIO DOS. Economia mundial, integração regional e desenvolvimento sustentável - as novas tendências da economia mundial e a integração latino-americana. Petrópolis, Vozes 1994.

SEBRAE. Serviço Brasileiro de Apoio às Micro e Pequenas Empresas. Disponível em: www.sebrae.com.br . Acesso em março de 2011.

SIDRA (2006). Banco de Dados Agregados - IBGE. Disponível em: www.sidra.ibge.gov.br. Acesso em março de 2012.

SIMON, JEAN-CHRISTOPHE. Le contexte de la valorisation des substances naturelles: dimensions économiques, sociales et institutionnelles. Article: IRD editions, 2005.

SINDUSFARMA. Sindicato da Indústria de Produtos Farmacêuticos no Estado de São Paulo. Disponível em: www.sindusfarma.org.br . Acesso em agosto de 2010.

SHIELD, P. Global Natural Cosmetics Market: The Battle of the Standards Gains Pace. Article. 2009.

SHISEIDO. Homepage institucional. Disponível em: www.shiseido.co.jp/com. Acesso em agosto de 2011. 
SHRINIVAS, P. Market research data on Essential oils and absolutes used in fragrance and flavor industry. Article, 2009.

SOUZA, I. D. S et al. O Levantamento de Patentes na Determinação de Tendências Tecnológicas no Setor Cosmético. Artigo In.: XXXI ENCONTRO NACIONAL DE ENGENHARIA DE PRODUCAO. Belo Horizonte, MG, Brasil, 04 a 07 de outubro de 2011.

SOUZA, M. T. S. de. Rumo à prática empresarial sustentável. Revista de Administração de Empresas, vol. 33, no 4, São Paulo: RAE, jul/ago de 1993.

STIENS, R. La Vérité sur les Cosmétiques. Deuxième impression, Paris: LEDUC.S Éditions, janvier 2010.

STROHER, A. et al. Nanocosméticos: conceitos, vantagens e aplicações. Cosmetics \& Toiletries (ed. Português), v.22, p. 54-60, 2010.

TEIXEIRA, S. A. Produção e consumo social da beleza. Horizontes Antropológicos, Porto Alegre, ano 7, n. 16, dezembro de 2001.

THE BODY SHOP. Homepage institucional. Disponível em: www.thebodyshop.co.uk/ . Acesso em agosto de 2011.

THE MARKETING INSIDER. The Market Lifestyles of Health and Sustainability. Disponível em: www.marketing-insider.com. Acesso em dezembro de 2010.

TOUROUDE, M. Le B-A BA des Brevets Cosmetiques. Interview en 20 mars 2009. Disponível em: www.demaquillages.com. Acesso em abril de 2010. UEBT. UNION FOR ETHICAL BIOTRADE. Report Biodiversity Barometer (2012). Disponível em: www.ethicalbiotrade.org/. Acesso em: setembro de 2012. 
UNESP CIÊNCIA. Pé Inovação: inspirado em premio Nobel, cosmético criado a partir da biodiversidade por pequena empresa brasileira supera as dificuldades de pesquisa e desenvolvimento nas relações entre universidade e indústria. Reportagem Bioprospeção, abril de 2010. Disponível em: http://www.unesp.br/revista. Acesso em dezembro de 2011.

UNITED NATIONS. Agenda 21. Programme of Action for Sustainable Development. New York: Unitde Nations, 1992.

USPTO. United States Patent and Trademark Office. Disponível em: www.uspto.gov/. Acesso em: maio de 2012.

VELHO, L. Modos de produção de conhecimento e inovação. Estado da arte e implicações para a política científica, tecnológica e de inovação. In: VELHO, L. (Org.). Nova geração de política em ciência, tecnologia e inovação. Brasília, DF: CGEE, 2010, p. 23-40.

VERAS, R. P. Considerações acerca de um jovem país que envelhece. Cadernos de Saúde Pública, Rio de Janeiro, out/dez, 1988.

VIANNA, L. C. R. A Idade Mídia: uma reflexão sobre o mito da juventude na cultura de massa. Série Antropologia, Brasília, v. 121, p. 1-42, 1992.

VIOLA, E. A multidimensionalidade da globalização, as novas forças sociais transnacionais e seu impacto na política ambiental no Brasil, 1989-1995. In. Incertezas de Sustentabilidade na Globalização. Leila da Costa Ferreira, Eduardo Viola (orgs.) Campinas: UNICAMP, 1996.

WITTNER, LAURENCE. Bien choisir vos cosmétiques: comment préserver votre peau et votre santé. Paris: Éditions Médicis, 2009.

WWD. Beauty's Top 100: ranking the global power players. Beauty Report International, 2009. 
XAVIER, M.L.P. et all. O novo perfil econômico do Grande ABC. Organizações em contexto, 3(6), dezembro, 2007;

YVES ROCHER. Homepage institucional. Disponível em: www.yvesrocher.com/. Acesso em abril de 2012. 
ANEXO 1 - Número de cirurgias plásticas no mundo - 2010

\begin{tabular}{|c|c|c|c|c|c|c|c|c|}
\hline \multicolumn{9}{|c|}{ Countries by Total Number of Procedures (Top 25) } \\
\hline Rank & & $\begin{array}{c}\text { Total Surgical } \\
\text { Procedures }\end{array}$ & $\begin{array}{c}\text { Sof of total } \\
\text { surgical } \\
\text { procedures }\end{array}$ & $\begin{array}{c}\text { Total } \\
\text { Nonsurgical } \\
\text { Procedures } \\
\end{array}$ & $\begin{array}{l}\text { \% of total } \\
\text { nonsurgical } \\
\text { procedures }\end{array}$ & $\begin{array}{c}\text { Total } \\
\text { Procedures } \\
\end{array}$ & $\begin{array}{l}\times \text { of total } \\
\text { procodures }\end{array}$ & $\begin{array}{c}\text { Ranik } \\
\text { in } \\
2009^{*} \\
\end{array}$ \\
\hline 1 & U.S. & $1,620,855$ & $17.1 \%$ & $1,693,437$ & $18.6 \%$ & $3,314,292$ & $17.9 \%$ & 1 \\
\hline 2 & Brazil & $1,592,106$ & $16.8 \%$ & 925,672 & $10.2 \%$ & $2,517,778$ & $13.6 \%$ & 2 \\
\hline 3 & China & 588,880 & $6.2 \%$ & 676,280 & $7.4 \%$ & $1,265,160$ & 6.896 & 3 \\
\hline 4 & Japan & 525,790 & $5.6 \%$ & 657,530 & $7.2 \%$ & $1,183,320$ & 6.496 & 6 \\
\hline 5 & India & 553,420 & 5.896 & 593,640 & $6.5 \%$ & $1,147,060$ & $6.2 \%$ & 4 \\
\hline 6 & Mexico & 437,351 & $4.6 \%$ & 479,749 & $5.3 \%$ & 917,100 & 4.996 & 5 \\
\hline 7 & Italy & 396,750 & $4.2 \%$ & 418,995 & $4.6 \%$ & 815,745 & 4.496 & 9 \\
\hline 8 & Korea, South & 361,988 & $3.8 \%$ & 408,925 & $4.5 \%$ & 770,913 & $4.2 \%$ & 7 \\
\hline 9 & France & 261,198 & $2.8 \%$ & 249,943 & $2.7 \%$ & 511,142 & $2.8 \%$ & 14 \\
\hline 10 & Colombia & 319,305 & $3.4 \%$ & 173,822 & $1.9 \%$ & 493,126 & 2.796 & 17 \\
\hline 11 & Germany & 229,273 & $2.4 \%$ & 218,615 & $2.4 \%$ & 447,888 & 2.496 & 8 \\
\hline 12 & Turkey & 205,114 & 2.296 & 224,196 & $2.5 \%$ & 429,310 & 2.396 & 11 \\
\hline 13 & Spain & 150,459 & $1.6 \%$ & 154,190 & $1.7 \%$ & 304,649 & $1.6 \%$ & 12 \\
\hline 14 & Russia & 138,854 & $1.5 \%$ & 135,728 & $1.5 \%$ & 274,583 & $1.5 \%$ & 10 \\
\hline 15 & Canada & 117,164 & 1.296 & 138,559 & $1.5 \%$ & 255,723 & 1.496 & 16 \\
\hline 16 & United Kingdom & 118,467 & 1.396 & 116,645 & $1.3 \%$ & 235,112 & 1.396 & 18 \\
\hline 17 & Taiwan & 102,708 & $1.1 \%$ & 118,409 & $1.3 \%$ & 221,116 & $1.2 \%$ & 19 \\
\hline 18 & Venezuela & 130,595 & 1.496 & 79,848 & $0.9 \%$ & 210,443 & 1.196 & 20 \\
\hline 19 & Argentina & 117,140 & $1.2 \%$ & 76,954 & $0.8 \%$ & 194,094 & 1.096 & 13 \\
\hline 20 & Thailand & 77,417 & 0.896 & 85,205 & $0.9 \%$ & 162,623 & 0.996 & 21 \\
\hline 21 & Greece & 76,471 & $0.8 \%$ & 82,531 & $0.9 \%$ & 159,002 & 0.996 & $\cdot$ \\
\hline 22 & Saudi Arabia & 66,310 & $0.7 \%$ & 74,702 & $0.8 \%$ & 141,012 & 0.896 & 25 \\
\hline 23 & Australia & 61,364 & 0.696 & 78,662 & $0.9 \%$ & 140,026 & 0.896 & 22 \\
\hline 24 & Netherlands & 57,358 & 0.696 & 55,163 & $0.6 \%$ & 112,520 & 0.696 & $\bullet$ \\
\hline 25 & Romania & 52,854 & $0.6 \%$ & 52,232 & $0.6 \%$ & 105,086 & 0.696 & $\bullet$ \\
\hline
\end{tabular}

\begin{tabular}{|c|c|c|c|c|c|c|}
\hline \multicolumn{7}{|c|}{ Number of Procedures and Plastic Surgeons by Continent } \\
\hline Rank & Continent & Total Procodures & $\begin{array}{c}\text { Percent of Total } \\
\text { Procedures }\end{array}$ & Plastic Surgeons & $\begin{array}{l}\text { Percent of Total } \\
\text { Plastic Surgeons }\end{array}$ & $\begin{array}{l}\text { Rank in } \\
2009^{*}\end{array}$ \\
\hline 1 & Asia & $5,879,349$ & $31.7 \%$ & 9,512 & $28.8 \%$ & 1 \\
\hline 2 & North America & $4,566,581$ & $24.6 \%$ & 8,042 & $24.3 \%$ & 2 \\
\hline 3 & Europe & $3,980,135$ & $21.4 \%$ & 7,469 & $22.6 \%$ & 3 \\
\hline 4 & South America & $3,645,758$ & $19.6 \%$ & 7,137 & $21.6 \%$ & 4 \\
\hline 5 & Africa & 320,006 & $1.7 \%$ & 594 & 1.896 & 5 \\
\hline 6 & Oceania & 165,997 & $0.9 \%$ & 273 & 0.896 & 6 \\
\hline & Total & $18,557,825$ & & 33,027 & & \\
\hline
\end{tabular}




\section{ANEXO 1 - Procedimentos cirúrgicos estéticos mais realizados no mundo - 2010}

\begin{tabular}{|c|c|c|c|c|}
\hline \multicolumn{5}{|c|}{ Countries Performing Most Popular Surgical Procedures } \\
\hline Rank & Country & Number of Procedures & Percentage of Total & Rank in $2010^{*}$ \\
\hline \multicolumn{5}{|c|}{ Lipoplasty } \\
\hline 1 & Brazil & 436,887 & $20.1 \%$ & 1 \\
\hline 2 & U.S. & 402,259 & $18.5 \%$ & 2 \\
\hline 3 & China & 134,720 & $6.2 \%$ & 3 \\
\hline 4 & India & 130,480 & $6.0 \%$ & 4 \\
\hline 5 & Japan & 118,612 & $5.5 \%$ & 5 \\
\hline \multicolumn{5}{|c|}{ Breast augmentation } \\
\hline 1 & U.S. & 336,648 & $22.3 \%$ & 2 \\
\hline 2 & Brazil & 254,214 & $16.9 \%$ & 3 \\
\hline 3 & Mexico & 85,099 & $5.6 \%$ & 5 \\
\hline 4 & Italy & 75,225 & $5.0 \%$ & * \\
\hline 5 & China & 55,400 & $3.7 \%$ & 1 \\
\hline \multicolumn{5}{|c|}{${ }^{*}$ Did not place in Top 9 for 2009 . Indis fell from the top 9 in 2010} \\
\hline \multicolumn{5}{|c|}{ Blepharoplasty } \\
\hline 1 & Brazil & 155,543 & $14.3 \%$ & 3 \\
\hline 2 & U.S. & 127,937 & $11.8 \%$ & 2 \\
\hline 3 & China & 73,480 & $6.8 \%$ & 1 \\
\hline 4 & Japan & 66,172 & $6.1 \%$ & 5 \\
\hline 5 & Italy & 63,330 & $5.8 \%$ & * \\
\hline \multicolumn{5}{|c|}{ Rhinoplasty } \\
\hline 1 & Brazil & 106,609 & $10.8 \%$ & 3 \\
\hline 2 & U.S. & 75,521 & $7.7 \%$ & 1 \\
\hline 3 & China & 125,700 & $12.8 \%$ & 2 \\
\hline 4 & India & 113,040 & $11.5 \%$ & 4 \\
\hline 5 & Japan & 112,497 & $11.4 \%$ & * \\
\hline${ }^{*}$ Did no & ece in Top 9 for 2009. Me & 5 in 2010. & & \\
\hline \multicolumn{5}{|c|}{ Abdominoplasty } \\
\hline 1 & U.S. & 154,265 & $22.6 \%$ & 1 \\
\hline 2 & Brazil & 125,600 & $18.4 \%$ & 3 \\
\hline 3 & Mexico & 39,756 & $5.8 \%$ & * \\
\hline 4 & India & 33,660 & $4.9 \%$ & 4 \\
\hline $\begin{array}{c}5 \\
.0 \text { Did no }\end{array}$ & $\begin{array}{l}\text { China } \\
\text { sce in Top } 9 \text { for 2009. Jag }\end{array}$ & in $2010^{33,480}$ & $4.9 \%$ & 2 \\
\hline
\end{tabular}




\section{ANEXO 2 - RESOLUCC̃̃O - RDC № 211, DE 14 DE JULHO DE 2005}

O Diretor-Presidente da Agência Nacional de Vigilância Sanitária - Anvisa, no uso da atribuição que Ihe confere o inciso IV do artigo 13 do Regulamento da Anvisa aprovado pelo Decreto 3.029, de 16 de abril de 1.999,

considerando a necessidade de atualizar as normas e procedimentos constantes da Resolução no 79 , de 28 de agosto de 2.000 , referentes a registro de produtos de higiene pessoal, cosméticos e perfumes e outros com abrangência neste contexto, com base na Lei 6.360, de 23 de setembro de 1.976 e seu Regulamento, Decreto 79.094, de 5 de janeiro de 1.977 e na Resolução ANVS n 335 , de 22 de julho de 1.999, suas atualizações ou instrumentos legais que venham a substituí-la;

considerando que a Vigilância Sanitária tem como missão precípua a prevenção de agravos à saúde, a ação reguladora de garantia de qualidade de produtos e serviços que inclui a aprovação de normas e suas atualizações, bem como a fiscalização de sua aplicação;

considerando a importância de compatibilizar os regulamentos nacionais com os instrumentos harmonizados no âmbito do Mercosul, em especial as Resoluções GMC no 110/94 (Anexo I), 07/05 (Anexo II), 26/04 (Anexo III), 36/04 (Anexo IV), 36/99 (Anexo V) e 24/95 (Anexo VII);

considerando as Consultas Públicas realizadas por meio das Portarias GM № 274 e № 275, de 27 de fevereiro de 2004 (DOU 01/03/04) e da Portaria GM № 1185, de 15 de junho de 2004 (DOU 17/06/04);

considerando que a legislação sanitária vigente se aplica a produtos nacionais e importados, provenientes dos Estados Partes do Mercosul e de outros países (produtos extra-zona);

considerando a importância do assunto, adota ad referendum a seguinte Resolução de Diretoria Colegiada e eu, Diretor-Presidente, determino a sua publicação:

adota, "ad referendum", a seguinte Resolução de Diretoria Colegiada e determina a sua publicação:

Art.1ำ - Ficam estabelecidas a Definição e a Classificação de Produtos de Higiene Pessoal, Cosméticos e Perfumes, conforme Anexos I e II desta Resolução.

Art. $2^{\circ}$ - Ficam estabelecidos os requisitos técnicos específicos para Produtos de Higiene Pessoal, Cosméticos e Perfumes, conforme o Anexo III desta Resolução.

Estabelece a Definição e a Classificação de Produtos de Higiene Pessoal, Cosméticos e Perfumes, conforme Anexo I e II desta Resolução e dá outras definições.

Art.3ำ - Ficam estabelecidos os requisitos para a rotulagem obrigatória geral para Produtos de Higiene Pessoal, Cosméticos e Perfumes conforme o Anexo IV desta Resolução.

Art.4 - Ficam estabelecidos os requisitos para a rotulagem específica de Produtos de Higiene Pessoal, Cosméticos e Perfumes conforme o Anexo V desta Resolução. 
Art.5 - Outras obrigatoriedades exigidas pelos Decretos 79.094/77 e 83.239/79 para os Produtos de Higiene Pessoal, Cosméticos e Perfumes estão mencionadas no Anexo VI desta Resolução.

Art.6ำ - Ficam estabelecidos requisitos adicionais para Produtos de Higiene Pessoal, Cosméticos e Perfumes importados Mercosul e extra-zona, conforme no Anexo VII desta Resolução.

Art. $7^{0}$ - A regularização sanitária dos produtos classificados como de Grau 1, ficam sujeitos a normas específicas estabelecidas pela Resolução ANVS n 335/99, de 22 de julho de 1.999, suas atualizações ou instrumentos legais que venham a substituí-la.

Art. $8^{\circ}$ - As informações necessárias para a regularização sanitária dos produtos classificados como de Grau 2 constam do peticionamento eletrônico e estão disponíveis no Sistema de Atendimento e Arrecadação On Line (peticionamento eletrônico) da Anvisa e na página de cosméticos do sítio eletrônico da Anvisa (www.anvisa.gov.br).

Parágrafo Único - A lista de documentos necessários e as orientações para o preenchimento dos formulários eletrônicos do Sistema de Atendimento e Arrecadação On Line (peticionamento eletrônico) encontram-se no sítio eletrônico da Anvisa na página de Cosméticos e no próprio peticionamento eletrônico.

Art.9 $9^{\circ}$ - Os documentos e informações necessários ao registro, suas alterações, revalidação, cancelamento e outros procedimentos afins estão descriminados no Sistema de Atendimento e Arrecadação On Line e no sítio eletrônico da Anvisa conforme tabela abaixo:

\section{ASSUNTOS DE PETIÇÃO RELATIVOS A REGISTRO DE PRODUTO GRAU 2}

Alteração do Prazo de Validade de Produto Grau 2

Alteração dos Dizeres de Rotulagem de Produto Grau 2

Cancelamento de Tonalidade a pedido de Produto Grau 2

Cancelamento de Registro do Produto a Pedido

Cancelamento de Acondicionamento do Produto Grau 2

Cancelamento do Registro por Alteração de Titularidade da Empresa

Certidão de Registro

Certidão de Registro para Exportação

Certificado de Venda Livre de Produto Registrado

Certificado de Venda Livre de Produto Registrado para Exportação

Inclusão de Acondicionamento Para Produto Grau 2

Inclusão de Tonalidade de Produto Grau 2

Inclusão de Tonalidade de Produto Grau 2 - Importado

Modificação de Fórmula de Produto Grau 2

Modificação de Fórmula de Produto Grau 2 - Importado

Mudança de Nome de Tonalidade de Produto Grau 2

Mudança de Nome de Produto Grau 2

Mudança de Local de Fabricação de Produto Grau de Risco 2 - no âmbito nacional

Mudança de Local de Fabricação de Produto Grau 2 - Importado para Nacional

Mudança de Local de Fabricação de Produto Grau 2 - Nacional para Importado

Reconsideração de Indeferimento de Alteração de Registro

Reconsideração de Indeferimento de Registro de Produto Grau 2

Registro de Produto Grau 2 - Nacional

Registro de Produto Grau 2 - Importado 
Registro de Produto Grau 2 - Exclusivo para Exportação

Retificação de Publicação de Alterações de Registro de Produto Grau 2

Retificação de Publicação de Registro de Produto Grau 2

Revalidação de Registro de Produto Grau 2

Substituição do Acondicionamento de Produto Grau 2

Transferência de Titularidade

Art.10 - Toda a documentação a ser encaminhada a Agência Nacional de Vigilância Sanitária do Ministério da Saúde, referente ao pedido de registro de Produto de Higiene Pessoal, Cosméticos e Perfumes classificados como de Grau 2 deverá ser assinada pelo representante legal e pelo responsável técnico da empresa.

Art.11 - Os procedimentos necessários ao registro estão descriminados no Sistema de Atendimento e Arrecadação On Line e no sítio eletrônico da Anvisa.

Art.12 - Os processos indeferidos referentes aos Produtos de Higiene Pessoal, Cosméticos e Perfumes e outros de natureza e finalidades idênticas terão o prazo de 10 (dez) dias a partir da publicação desta resolução para apresentação de recursos ou solicitação dos documentos, pela parte interessada.

Art.13 - Ficam revogados os Anexos I, VII, VIII, IX, X, XI, XII, XIII, XIV, XV, XVII, XVIII, XIX, XX e XXI da Resolução no 79/00, de 28 de agosto de 2000.

Art.14 - O disposto nesta Resolução não exclui a observância de outros regulamentos previstos na legislação sanitária, pertinentes aos Produtos de Higiene Pessoal, Cosméticos e Perfumes.

Art.15 - O descumprimento desta resolução constitui infração sanitária, ficando o infrator sujeito às penalidades previstas na lei no 6.437, de 20 de Agosto de 1977 e demais pertinentes.

Art.16 - Esta Resolução de Diretoria Colegiada entra em vigor na data de sua publicação.

DIRCEU RAPOSO DE MELLO

ANEXO I

DEFINIÇÃO DE PRODUTOS DE HIGIENE PESSOAL, COSMÉTICOS E PERFUMES

1. Produtos de Higiene Pessoal, Cosméticos e Perfumes, são preparações constituídas por substâncias naturais ou sintéticas, de uso externo nas diversas partes do corpo humano, pele, sistema capilar, unhas, lábios, órgãos genitais externos, dentes e membranas mucosas da cavidade oral, com o objetivo exclusivo ou principal de limpá-los, perfumá-los, alterar sua aparência e ou corrigir odores corporais e ou protegê-los ou mantê-los em bom estado.

ANEXO II

CLASSIFICAÇÃO DE PRODUTOS DE HIGIENE PESSOAL, COSMÉTICOS E PERFUMES

1. Definição de Produtos Grau 1: são produtos de higiene pessoal cosméticos e perfumes cuja formulação cumpre com a definição adotada no item 1 do Anexo I desta 
Resolução e que se caracterizam por possuírem propriedades básicas ou elementares, cuja comprovação não seja inicialmente necessária e não requeiram informações detalhadas quanto ao seu modo de usar e suas restrições de uso, devido às características intrínsecas do produto, conforme mencionado na lista indicativa "LISTA DE TIPOS DE PRODUTOS DE GRAU 1" estabelecida no item "I" deste Anexo.

2. Definição de Produtos Grau 2: são produtos de higiene pessoal cosméticos e perfumes cuja formulação cumpre com a definição adotada no item 1 do Anexo I desta Resolução e que possuem indicações específicas, cujas características exigem comprovação de segurança e/ou eficácia, bem como informações e cuidados, modo e restrições de uso, conforme mencionado na lista indicativa "LISTA DE TIPOS DE PRODUTOS DE GRAU 2" estabelecida no item "II" deste Anexo.

3. Os critérios para esta classificação foram definidos em função da probabilidade de ocorrência de efeitos não desejados devido ao uso inadequado do produto, sua formulação, finalidade de uso, áreas do corpo a que se destinam e cuidados a serem observados quando de sua utilização.

\section{I) LISTA DE TIPOS DE PRODUTOS DE GRAU 1}

1 Água de colônia, Água Perfumada, Perfume e Extrato Aromático.

2 Amolecedor de cutícula (não cáustico).

3 Aromatizante bucal.

4 Base facial/corporal (sem finalidade fotoprotetora).

5 Batom labial e brilho labial (sem finalidade fotoprotetora).

6 Blush/Rouge (sem finalidade fotoprotetora).

7 Condicionador/Creme rinse/Enxaguatório capilar (exceto os com ação antiqueda, anticaspa e/ou outros benefícios específicos que justifiquem comprovação prévia).

8 Corretivo facial (sem finalidade fotoprotetora).

9 Creme, loção e gel para o rosto (sem ação fotoprotetora da pele e com finalidade exclusiva de hidratação).

10 Creme, loção, gel e óleo esfoliante ("peeling") mecânico, corporal e/ou facial.

11 Creme, loção, gel e óleo para as mãos (sem ação fotoprotetora, sem indicação de ação protetora individual para o trabalho, como equipamento de proteção individual EPI - e com finalidade exclusiva de hidratação e/ou refrescância).

12 Creme, loção, gel e óleos para as pernas (com finalidade exclusiva de hidratação e/ou refrescância).

13 Creme, loção, gel e óleo para limpeza facial (exceto para pele acnéica).

14 Creme, loção, gel e óleo para o corpo (exceto os com finalidade específica de ação antiestrias, ou anticelulite, sem ação fotoprotetora da pele e com finalidade exclusiva de hidratação e/ou refrescância).

15 Creme, loção, gel e óleo para os pés (com finalidade exclusiva de hidratação e/ou refrescância).

16 Delineador para lábios, olhos e sobrancelhas.

17 Demaquilante.

18 Dentifrício (exceto os com flúor, os com ação antiplaca, anticárie, antitártaro, com indicação para dentes sensíveis e os clareadores químicos).

19 Depilatório mecânico/epilatório.

20 Desodorante axilar (exceto os com ação antitranspirante).

21 Desodorante colônia.

22 Desodorante corporal (exceto desodorante íntimo).

23 Desodorante pédico (exceto os com ação antitranspirante).

24 Enxaguatório bucal aromatizante (exceto os com flúor, ação anti-séptica e antiplaca). 
25 Esmalte, verniz, brilho para unhas.

26 Fitas para remoção mecânica de impureza da pele.

27 Fortalecedor de unhas.

28 Kajal.

29 Lápis para lábios, olhos e sobrancelhas.

30 Lenço umedecido (exceto os com ação anti-séptica e/ou outros benefícios específicos

que justifiquem a comprovação prévia).

31 Loção tônica facial (exceto para pele acneica).

32 Máscara para cílios.

33 Máscara corporal (com finalidade exclusiva de limpeza e/ou hidratação).

34 Máscara facial (exceto para pele acneica, peeling químico e/ou outros benefícios específicos que justifiquem a comprovação prévia).

35 Modelador/fixador para sombrancelhas.

36 Neutralizante para permanente e alisante.

37 Pó facial (sem finalidade fotoprotetora).

38 Produtos para banho/imersão: sais, óleos, cápsulas gelatinosas e banho de espuma.

39 Produtos para barbear (exceto os com ação anti-séptica).

40 Produtos para fixar, modelar e/ou embelezar os cabelos: fixadores, laquês, reparadores de pontas, óleo capilar, brilhantinas, mousses, cremes e géis para modelar e assentar os cabelos, restaurador capilar, máscara capilar e umidificador capilar.

41 Produtos para pré-barbear (exceto os com ação anti-séptica).

42 Produtos pós-barbear (exceto os com ação anti-séptica).

43 Protetor labial sem fotoprotetor.

44 Removedor de esmalte.

45 Sabonete abrasivo/esfoliante mecânico (exceto os com ação anti-séptica ou esfoliante

químico).

46 Sabonete facial e/ou corporal (exceto os com ação anti-séptica ou esfoliante químico).

47 Sabonete desodorante (exceto os com ação anti-séptica).

48 Secante de esmalte.

49 Sombra para as pálpebras.

50 Talco/pó (exceto os com ação anti-séptica).

51 Xampu (exceto os com ação antiqueda, anticaspa e/ou outros benefícios específicos

que justifiquem a comprovação prévia).

52 Xampu condicionador (exceto os com ação antiqueda, anticaspa e/ou outros benefícios específicos que justifiquem comprovação prévia).

3. Observação: As exceções mencionadas no item "I) LISTA DE TIPOS DE PRODUTOS DE GRAU 1" caracterizam os produtos de Grau 2.

II) LISTA DE TIPOS DE PRODUTOS DE GRAU 2

1 Água oxigenada 10 a 40 volumes (incluídas as cremosas exceto os produtos de uso medicinal).

2 Antitranspirante axilar.

3 Antitranspirante pédico.

4 Ativador/ acelerador de bronzeado.

5 Batom labial e brilho labial infantil.

6 Bloqueador Solar/anti-solar.

7 Blush/ rouge infantil. 


\section{Bronzeador.}

9 Bronzeador simulatório.

10 Clareador da pele.

11 Clareador para as unhas químico.

12 Clareador para cabelos e pêlos do corpo.

13 Colônia infantil.

14 Condicionador anticaspa/antiqueda.

15 Condicionador infantil.

16 Dentifrício anticárie.

17 Dentifrício antiplaca.

18 Dentifrício antitártaro.

19 Dentifrício clareador/ clareador dental químico.

20 Dentrifrício para dentes sensíveis.

21 Dentifrício infantil.

22 Depilatório químico.

23 Descolorante capilar.

24 Desodorante antitranspirante axilar.

25 Desodorante antitranspirante pédico.

26 Desodorante de uso íntimo.

27 Enxaguatório bucal antiplaca.

28 Enxaguatório bucal anti-séptico.

29 Enxaguatório bucal infantil.

30 Enxaguatório capilar anticaspa/antiqueda.

31 Enxaguatório capilar infantil.

32 Enxaguatório capilar colorante / tonalizante.

33 Esfoliante "peeling" químico.

34 Esmalte para unhas infantil.

35 Fixador de cabelo infantil.

36 Lenços Umedecidos para Higiene infantil.

37 Maquiagem com fotoprotetor.

38 Produto de limpeza/ higienização infantil.

39 Produto para alisar e/ ou tingir os cabelos.

40 Produto para área dos olhos (exceto os de maquiagem e/ou ação hidratante e/ou demaquilante).

41 Produto para evitar roer unhas.

42 Produto para ondular os cabelos.

43 Produto para pele acneica.

44 Produto para rugas.

45 Produto protetor da pele infantil.

46 Protetor labial com fotoprotetor.

47 Protetor solar.

48 Protetor solar infantil.

49 Removedor de cutícula.

50 Removedor de mancha de nicotina químico.

51 Repelente de insetos.

52 Sabonete anti-séptico.

53 Sabonete infantil.

54 Sabonete de uso íntimo.

55 Talco/amido infantil.

56 Talco/pó anti-séptico.

57 Tintura capilar temporária/progressiva/permanente.

58 Tônico/loção Capilar.

59 Xampu anticaspa/antiqueda.

60 Xampu colorante. 
61 Xampu condicionador anticaspa/antiqueda.

62 Xampu condicionador infantil.

63 Xampu infantil.

ANEXO III

REQUISITOS TÉCNICOS ESPECÍFICOS PARA PRODUTOS DE HIGIENE PESSOAL, COSMÉTICOS E PERFUMES.

\begin{tabular}{|c|c|c|c|}
\hline Requisitos Obrigatórios & $\begin{array}{l}\text { Na empresa à } \\
\text { disposiçăo da } \\
\text { autoridade } \\
\text { competente } \\
\end{array}$ & $\begin{array}{c}\text { Apresentar para } \\
\text { autorização de } \\
\text { comercializaçăo do } \\
\text { produto } \\
\end{array}$ & Observaçס̄es \\
\hline $\begin{array}{l}\text { 1. Fómula quali- } \\
\text { quantitativa }\end{array}$ & $\bar{x}$ & $\bar{X}$ & $\begin{array}{|lr|}\text { Com todos seus } \\
\text { componentes } \\
\text { especificados } \\
\text { suas denominacōes } \\
\text { INCl e as quantidades } \\
\text { de cada r um } \\
\text { expressas } \\
\text { percentualmente (p/p) } \\
\text { através do sistema } \\
\text { métrico decimal. }\end{array}$ \\
\hline $\begin{array}{l}\text { 2. Função dos } \\
\text { ingredientes da fórmula }\end{array}$ & $\bar{X}$ & $\bar{X}$ & $\begin{array}{l}\text { Citar a funçāo de } \\
\text { cada componente na } \\
\text { fórmula. }\end{array}$ \\
\hline $\begin{array}{l}\text { 3. Bibliografia e/ou } \\
\text { referência dos } \\
\text { ingredientes }\end{array}$ & $\bar{X}$ & $\mathrm{X}$ & $\begin{array}{|lr|}\text { Somente } & \text { quando } \\
\text { componenter nāo } \\
\text { figura } & \text { na } \\
\text { nomenclatura INCI ou } \\
\text { nāo se enquadra nas } \\
\text { listas de substâncias } \\
\text { aprovadas, incluir } \\
\text { bibliografia r sobre o } \\
\text { mesmo e literatura } \\
\text { pertinentes, inclusive } \\
\text { com relaçāo a eficácia } \\
\text { e a segurança. }\end{array}$ \\
\hline $\begin{array}{l}\text { Especificaçōes } \\
\text { Técnicas organolépticas } \\
\text { e físico-químicas de } \\
\text { matérias primas }\end{array}$ & $\bar{X}$ & & \\
\hline $\begin{array}{l}\text { 5. Especificaçōes } \\
\text { microbiológicas de } \\
\text { matérias-primas }\end{array}$ & $\bar{X}$ & & Quando aplicável. \\
\hline $\begin{array}{l}\text { Especificaçōes técnicas } \\
\text { organolépticas } \theta \text { físico- } \\
\text { químicas do produto } \\
\text { acabado. }\end{array}$ & $\bar{x}$ & $\bar{x}$ & \\
\hline $\begin{array}{l}\text { 7. Especificaçōes } \\
\text { microbiológicas do }\end{array}$ & $\mathrm{X}$ & $\mathrm{X}$ & $\begin{array}{l}\text { Quando aplicável, } \\
\text { conforme legislaçāo }\end{array}$ \\
\hline
\end{tabular}




\begin{tabular}{|c|c|c|c|}
\hline produto acabado & & & vigente \\
\hline 8. Processo de Fabricação & $\bar{X}$ & & $\begin{array}{l}\text { Segundo as Normas } \\
\text { de Boas Práticas de } \\
\text { Fabricaçăo e Controle } \\
\text { previstas r na } \\
\text { legislaçäo. }\end{array}$ \\
\hline $\begin{array}{l}\text { 9. Especificaçöes técnicas } \\
\text { do material de } \\
\text { embalagem }\end{array}$ & $\bar{x}$ & & \\
\hline 10. Dados de estabilidade & $\mathrm{X}$ (completo) & $\mathrm{X}$ (resumo) & $\begin{array}{l}\text { Metodologia } \\
\text { conclusōes que } \\
\text { garantem o prazo de } \\
\text { validade declarado. }\end{array}$ \\
\hline $\begin{array}{l}\text { 11. Sistema de codificação } \\
\text { de lote }\end{array}$ & $\mathrm{X}$ & & $\begin{array}{l}\text { Informação para } \\
\text { interpretar o sistema } \\
\text { de codificaçăo. }\end{array}$ \\
\hline $\begin{array}{l}\text { 12. Projeto de Arte de } \\
\text { Etiqueta ou rotulagem }\end{array}$ & $\bar{X}$ & $\bar{X}$ & $\begin{array}{l}\text { Informaçōes de dados } \\
\text { eradvertências } \\
\text { referentes ao produto } \\
\text { conformer legislaçäo } \\
\text { vigente. }\end{array}$ \\
\hline $\begin{array}{l}\text { 13. Dados comprobatórios } \\
\text { dos benefícios } \\
\text { atribuídos ao produto } \\
\text { (comprovaçäo de } \\
\text { eficácia) }\end{array}$ & $\bar{X}$ & & $\begin{array}{l}\text { Sempre que a } \\
\text { natureza do beneficio } \\
\text { do produto justifique e } \\
\text { sempre que conste da } \\
\text { rotulagem. }\end{array}$ \\
\hline $\begin{array}{l}\text { 14. Dados de segurança de } \\
\text { uso (comprovaçăo de } \\
\text { segurança) }\end{array}$ & $\bar{X}$ & & \\
\hline 15. Finalidade do produto & $\mathrm{X}$ & $\mathrm{X}$ & $\begin{array}{l}\text { A finalidade a que se } \\
\text { destina o produto } \\
\text { quando năo estiver } \\
\text { implícito no nome do } \\
\text { mesmo. }\end{array}$ \\
\hline $\begin{array}{l}\text { 16. Certificado de Venda } \\
\text { Livre consularizado (1) }\end{array}$ & $\mathrm{X}$ (original) & $\bar{X}$ (cópia autenticada) & $\begin{array}{c}\text { Conforme legislaçäo } \\
\text { vigente }\end{array}$ \\
\hline $\begin{array}{l}\text { 17. Registro/Autorizaçäo de } \\
\text { empresa/Certificado de } \\
\text { Inscriçäa do } \\
\text { Estabelecimento }\end{array}$ & $\mathrm{X}$ & & $\begin{array}{c}\text { Conforme legislaçäo } \\
\text { vigente. }\end{array}$ \\
\hline $\begin{array}{l}\text { 18. Fórmula do produto } \\
\text { importado } \\
\text { consularizada }\end{array}$ & $\mathrm{X}$ (original) & X (cópia autenticada) & $\begin{array}{l}\text { Caso esta näo esteja } \\
\text { anexa ao Certificado } \\
\text { de Venda Livre, } \\
\text { conforme legislaçäo } \\
\text { vigente. }\end{array}$ \\
\hline
\end{tabular}


(1) Certificado de Venda Livre: corresponde ao Certificado de Livre Comercialização outorgado pela Autoridade Sanitária competente ou por Organismos Oficialmente Reconhecidos no país de origem.

\section{ANEXO IV}

\section{REGULAMENTO TÉCNICO SOBRE ROTULAGEM OBRIGATÓRIA GERAL PARA PRODUTOS DE HIGIENE PESSOAL, COSMÉTICOS E PERFUMES}

\section{A) OBJETIVO}

Estabelecer as informações indispensáveis que devem figurar nos rótulos dos Produtos de Higiene Pessoal, Cosméticos e Perfumes, concernentes a sua utilização, assim como toda a indicação necessária referente ao produto.

\section{B) DEFINIÇÕES}

1 Embalagem Primária: envoltório ou recipiente que se encontra em contato direto com os produtos.

2 Embalagem Secundária: é a embalagem destinada a conter a embalagem primária ou as embalagens primárias.

3 Rótulo: identificação impressa ou litografada, bem como dizeres pintados ou gravados, decalco sob pressão ou outros, aplicados diretamente sobre recipientes, embalagens, invólucros, envoltórios ou qualquer outro protetor de embalagens.

4 Folheto de Instruções: texto impresso que acompanha o produto, contendo informações complementares.

5 Nome/Grupo/Tipo: designação do produto para distinguí-lo de outros, ainda que da mesma empresa ou fabricante, da mesma espécie, qualidade ou natureza.

6 Marca: elemento que identifica um ou vários produtos da mesma empresa ou fabricante e que os distingue de produtos de outras empresas ou fabricantes, segundo a legislação de propriedade industrial.

7 Origem: lugar de produção ou industrialização do produto.

8 Lote ou Partida: Quantidade de um produto em um ciclo de fabricação, devidamente identificado, cuja principal característica é a homogeneidade.

9 Prazo de Validade: tempo em que o produto mantém suas propriedades, quando conservado na embalagem original e sem avarias, em condições adequadas de armazenamento e utilização.

10 Titular de registro: pessoa jurídica ou denominação equivalente definida no ordenamento jurídico nacional que possui registro de Produtos de Higiene Pessoal, Cosméticos e Perfumes.

11 Elaborador/Fabricante: empresa que possui as instalações necessárias para a fabricação/elaboração de Produtos de Higiene Pessoal, Cosméticos e Perfumes.

12 Importador: pessoa jurídica ou denominação equivalente definida no ordenamento 
jurídico nacional responsável pela introdução em um país, de Produtos de Higiene Pessoal, Cosméticos e Perfumes estrangeiros.

13 Número de Registro do Produto: corresponde ao número de identificação de empresa e o número de Resolução ou Autorização de comercialização do produto.

14 Ingredientes/Composição: descrição qualitativa dos componentes da fórmula através de sua designação genérica, utilizando a codificação de substâncias estabelecida pela Nomenclatura Internacional de Ingredientes Cosméticos (INCI).

15 Advertências e Restrições de Uso: são as estabelecidas nas listas de substâncias quando exigem a obrigatoriedade de informar a presença das mesmas no rótulo e aquelas estabelecidas no Anexo $\mathrm{V}$ desta Resolução "Regulamento Técnico sobre Rotulagem Específica para Produtos de Higiene Pessoal, Cosméticos e Perfumes".

C) ROTULAGEM OBRIGATÓRIA GERAL

REF. ÍTEM EMBALAGEM

\begin{tabular}{|l|l|l|}
\hline REF. & ITEM & EMBALAGEM \\
\hline 1 & $\begin{array}{l}\text { Nome do produto e grupo/tipo a que } \\
\text { pertence no caso de não estar implícito } \\
\text { no nome. }\end{array}$ & \\
\hline 2 & Marca & Primária e Secundária \\
\hline 3 & Número de registro do produto & Secundária \\
\hline 4 & Lote ou Partida & Primária \\
\hline 5 & Prazo de Validade & Secundária \\
\hline 6 & Conteúdo & Secundária \\
\hline 7 & País de origem & Secundária \\
\hline 8 & Fabricante/lmportador/Titular & Secundária \\
\hline 9 & $\begin{array}{l}\text { Domićlio } \\
\text { Fabricante/lmportador/Titular }\end{array}$ & do Secundária \\
\hline 10 & Modo de Uso (se for o caso) & Primária ou Secundária \\
\hline 11 & $\begin{array}{l}\text { Advertências e Restrições de uso (se } \\
\text { for o caso) }\end{array}$ & Primária e Secundária \\
\hline 12 & $\begin{array}{l}\text { Rotulagem Específica (Conforme } \\
\text { Anexo V desta Resolução) }\end{array}$ & Primária e Secundária \\
\hline 13 & Ingredientes/Composição & Secundária \\
\hline
\end{tabular}




\section{D) OBSERVAÇÕES}

1 - Quando não existir embalagem secundária toda a informação requerida deve figurar na Embalagem Primária.

2 - O Modo de Uso poderá figurar em folheto anexo. Neste caso deverá indicar-se na embalagem primária: - "Ver folheto anexo".

3 - Quando a embalagem for pequena e não permitir a inclusão de advertências e restrições de uso, as mesmas poderão figurar em folheto anexo. Deverá estar indicado na embalagem primária: - "Ver folheto anexo".

\section{ANEXO V}

REGULAMENTO TÉCNICO SOBRE ROTULAGEM ESPECÍFICA PARA PRODUTOS DE HIGIENE PESSOAL, COSMÉTICOS E PERFUMES

\section{a) AEROSSÓIS}

1 Inflamável. Não pulverizar perto do fogo;

2 Não perfurar, nem incinerar;

3 Não expor ao sol nem à temperaturas superiores a $50^{\circ} \mathrm{C}$;

4 Proteger os olhos durante a aplicação;

5 Manter fora do alcance de crianças.

b) NEUTRALIZANTES, PRODUTOS PARA ONDULAR E ALISAR OS CABELOS:

1 Não aplicar se o couro cabeludo estiver irritado ou lesionado;

2 Manter fora do alcance das crianças.

c) AGENTES CLAREADORES DE CABELOS E TINTURAS CAPILARES:

1 Pode causar reação alérgica. Fazer a Prova de Toque (descrever);

2 Não usar nos cílios e sobrancelhas;

3 Não aplicar se o couro cabeludo estiver irritado ou lesionado;

4 Em caso de contato com os olhos, lavar com água em abundância;

5 Manter fora do alcance das crianças.

d) TINTURAS CAPILARES COM ACETATO DE CHUMBO:

1 Não aplicar se o couro cabeludo estiver irritado ou lesionado;

2 O uso inadequado pode provocar intoxicação por absorção de chumbo;

3 Aplicar somente no couro cabeludo (cabelos); 
4 Depois do uso, lavar as mãos com água em abundância para evitar a ingestão acidental;

5 Manter fora do alcance das crianças.

e) DEPILATÓRIOS E EPILATÓRIOS:

1 Não aplicar em áreas irritadas ou lesionadas;

2 Não deixar aplicado por tempo superior ao indicado nas instruções de uso;

3 Não usar com a finalidade de se barbear;

4 Em caso de contato com os olhos, lavar com água em abundância;

5 Manter fora do alcance das crianças.

f) DENTIFRÍCIOS E ENXAGUATÓRIOS BUCAIS COM FLÚOR:

1 Indicar o nome do composto de flúor utilizado e sua concentração em ppm (parte por milhão);

2 Indicar o modo de uso, quando necessário;

3 Não usar em crianças menores de 06 anos. (Somente para enxaguatórios bucais).

g) PRODUTOS ANTIPERSPIRANTES/ ANTITRANSPIRANTES:

1 Usar somente nas áreas indicadas;

2 Não usar se a pele estiver irritada ou lesionada;

3 Caso ocorra irritação e/ou prurido no local da aplicação, suspender o uso imediatamente.

h) TÔNICOS CAPILARES:

1 Em caso de eventual irritação do couro cabeludo, suspender o uso.

ANEXO VI

OUTRAS OBRIGATORIEDADES EXIGIDAS PELOS DECRETOS 79.094/77 E 83.239/79

1. Não poderão constar da rotulagem ou da publicidade e de propaganda dos produtos submetidos à presente Norma, designações, nomes geográficos, símbolos, figuras, desenhos ou quaisquer indicações que possibilitem interpretações falsas, erros ou confusão quanto à origem, procedência, natureza, composição ou qualidade, ou que atribuam ao produto finalidade ou características diferentes daquelas que realmente possua (Art. 93 - Decreto 79.094/77 alterado pelo Decreto 83.239/79).

2. Não será permitida a embalagem sob a forma de aerossóis para os talcos (Art. 125 Decreto 79.094/77). 
3. Os vasilhames dos produtos apresentados sob a forma de aerossol, sendo de vidro envolvido por material plástico, deverão conter pequenos orifícios para a saída do conteúdo, se quebrar (Art. 123 - Decreto 79.094/77).

4. Os vasilhames dos produtos sob a forma de premidos em aerossóis não poderão ter a capacidade superior a 500 (quinhentos) mililitros (Art. 124 - Decreto 79.094/77).

5. Além das advertências estabelecidas na Lista Restritiva "Lista de Substâncias que os Produtos de Higiene Pessoal, Cosméticos e Perfumes não devem conter, exceto nas condições e com as restrições estabelecidas" e do disposto nesta Resolução, deverão ser acrescidos em caráter obrigatório na embalagem primária e secundária, dos tipos de produtos abaixo mencionados, os dizeres específicos destacados entre aspas:

6. AEROSSÓIS: "Evite a inalação deste produto" (Art. 108 - Parágrafo Único - Decreto 79.094/77).

7. NEUTRALIZANTES, PRODUTOS PARA ONDULAR E ALISAR OS CABELOS: "Este preparado somente deve ser usado para o fim a que se destina, sendo PERIGOSO para qualquer outro uso" (Art.109 - Decreto 79.094/77).

7.1 AGENTES CLAREADORES DE CABELOS E TINTURAS CAPILARES: Os rótulos das tinturas e dos agentes clareadores de cabelos que contenham substâncias capazes de produzir intoxicações agudas ou crônicas deverão conter as advertências "CUIDADO. Contém substâncias passíveis de causar irritação na pele de determinadas pessoas. Antes de usar, faça a prova de toque" (Art.107- Decreto 79.094/77).

7.2.BRONZEADORES SIMULATÓRIOS: Os rótulos dos produtos destinados a simular o bronzeamento da pele deverão conter a advertência "Atenção: não protege contra a ação solar" (Art.106- Decreto 79.094/77).

7.3 PRODUTOS INFANTIS: Os produtos destinados ao uso infantil deverão ter mencionadas em sua rotulagem todas as advertências necessárias para evitar o uso inadequado.

ANEXO VII

REQUISITOS ADICIONAIS PARA PRODUTOS DE HIGIENE PESSOAL, COSMÉTICOS E PERFUMES IMPORTADOS MERCOSUL E EXTRA-ZONA

\section{Regularização de Produtos}

1.1. As Empresas Responsáveis pela Titularidade dos Registros de Produtos de Higiene Pessoal, Cosméticos e Perfumes importados (doravante Empresa Responsável) deverão apresentar à Autoridade Sanitária uma solicitação de Registro de Produto firmada pelo Representante Legal e pelo Responsável Técnico, acompanhada, dentre outras, da seguinte documentação:

a) Certificado de Livre Comercialização no país de origem, emitido pela Autoridade Sanitária competente e devidamente consularizado; 
b) Caso o Certificado de Livre Comercialização não contenha a fórmula qualiquantitativa esta deve ser juntada, firmada pelo Representante Legal e pelo Responsável Técnico da empresa fabricante e devidamente consularizada.

c) Comprovante do pagamento das taxas estabelecidas pela Autoridade Sanitária;

1.2. As Empresas Responsáveis e as Empresas Importadoras deverão possuir informação adicional a nível analítico sobre uso e segurança do produto para fornecer à Autoridade Sanitária se assim for requerido.

1.3. Rótulos, prospectos e embalagem. A documentação será acompanhada do rótulo. Serão anexados prospecto e embalagem do produto em questão quando estes forem utilizados. Essa documentação pode ser apresentada mediante fotocópias dos mesmos ou indicação dos textos correspondentes. Se o rótulo original não contiver a informação requerida, será aceita adequação mediante um sobre-rótulo ou etiqueta que contenha a informação faltante.

1.4. Será declarado que os ingredientes da formulação cumprem com a legislação sanitária nacional.

1.5. O prazo máximo para a Autoridade Sanitária manifestar-se sobre a regularização dos Produtos de Higiene Pessoal, Cosméticos e Perfumes apresentadas será de 60 dias.

Este texto não substitui o publicado no D.O.U. de 18 de julho de 2005. 
ANEXO 3 - Empresas Líderes no Faturamento de Cosméticos,

Perfumaria e Produtos de Higiene Pessoal

(faturamento em US\$ bilhões)

\begin{tabular}{|c|c|c|c|}
\hline Ranking & Indústrias & Cidade - País & 2008 \\
\hline 1 & L’Oréal & Clichy - França & 25.81 \\
\hline 2 & Procter \& Gamble & Cincinnati - EUA & 19.80 \\
\hline 3 & Unilever & $\begin{array}{l}\text { Londres - Reino Unido; } \\
\text { Roterdam - Holanda }\end{array}$ & 15.55 \\
\hline 4 & Estee Lauder Cos. & Nova York - EUA & 7.84 \\
\hline 5 & Avon & Nova York - EUA & 7.60 \\
\hline 6 & Beiersdorf & Hamburgo - Alemanha & 7.03 \\
\hline 7 & Shiseido & Tokyo - Japão & 6.49 \\
\hline 8 & Johnson \& Johnson & Nova Jersey - EUA & 5.80 \\
\hline 9 & KAO & Tokyo, Japão & 5.56 \\
\hline 10 & Chanel & Neuilly-sur-seine - França & 4.43 \\
\hline 11 & LVMH & Paris - França & 4.22 \\
\hline 12 & Coty & Nova York - EUA & 4.00 \\
\hline 13 & Henkel KGAA & Dusseldorf - Alemanha & 3.71 \\
\hline 14 & Natura & São Paulo - Brasil & 2.74 \\
\hline 15 & Mary Kay Inc. & Dallas - EUA & 2.60 \\
\hline 16 & Yves Rocher & Issy-Les-Moulleneaux - França & 2.34 \\
\hline 17 & Limited Brands & Columbia - EUA & 2.06 \\
\hline 18 & Oriflame & Estocolmo - Suécia & 1.96 \\
\hline 19 & Alticor & Ada - EUA & 1.90 \\
\hline 20 & Pacific Corp & Seul - Coréia do Sul & 1.84 \\
\hline 40 & O Boticário & Curitiba - Brasil & 581.68 \\
\hline 58 & Hypermarcas & São Paulo - Brasil & 284.15 \\
\hline
\end{tabular}

Fonte: WWD Beauty 100, 2009. 
ANEXO 4 - Participacão (\%) das Principais Empresas no Mercado Nacional por grandes subsegmentos -2009

Participação (\%) das Principais Empresas no Mercado Nacional: Produtos para banho - 2009

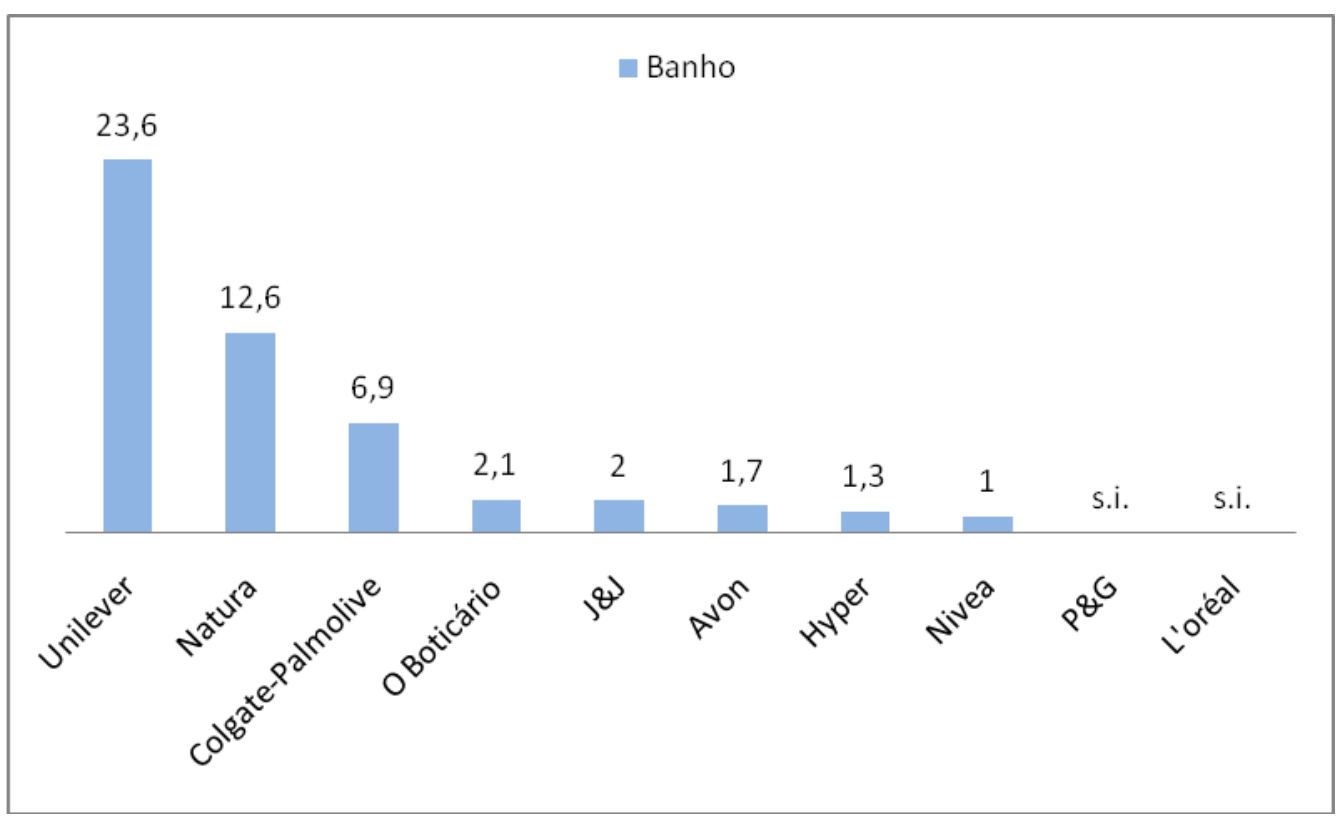

Fonte: EUROMONITOR, 2011. Elaborado pela autora.

Participação (\%) das Principais Empresas no Mercado Nacional: Produtos para cabelos -2009

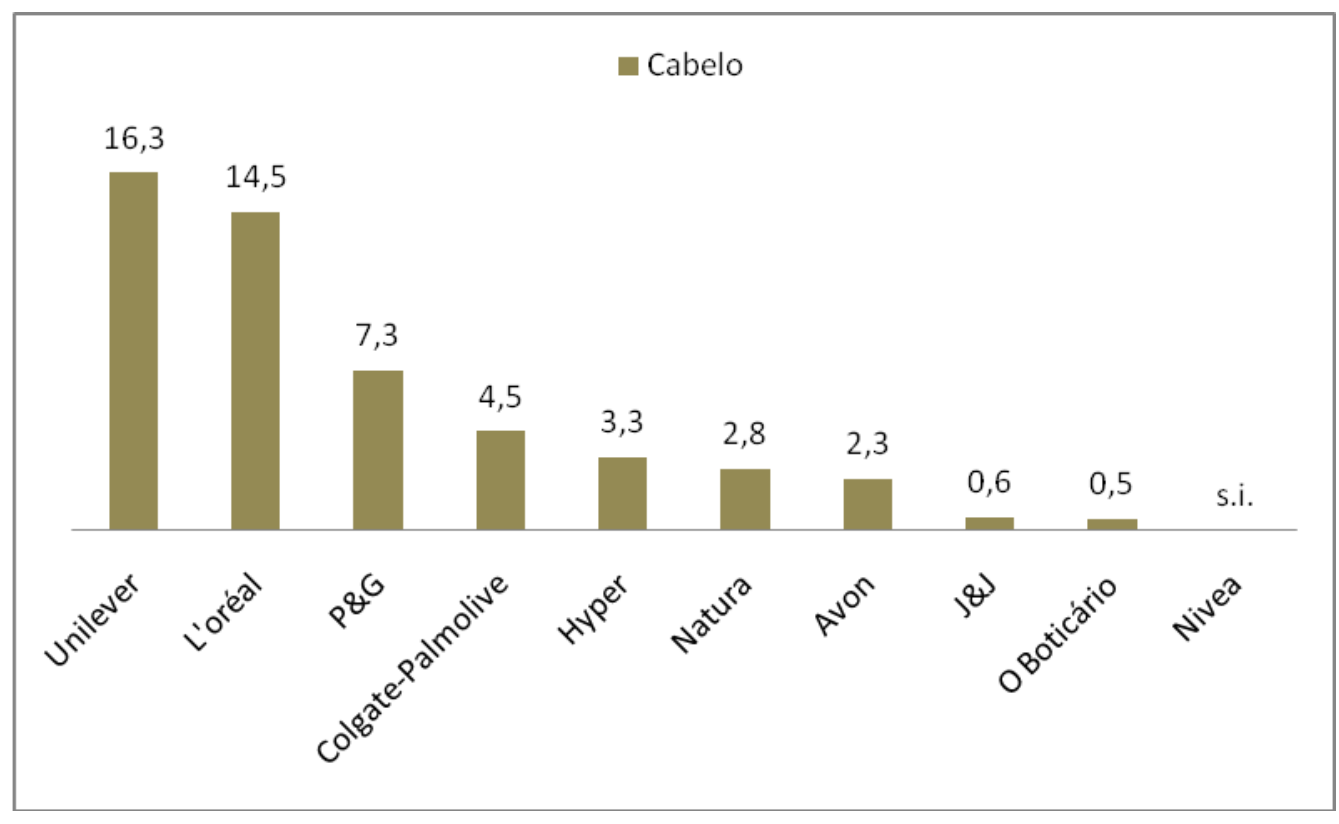

Fonte: EUROMONITOR, 2011. Elaborado pela autora. 
ANEXO 4 - Participacão (\%) das Principais Empresas no Mercado Nacional por grandes subsegmentos - 2009

Participação (\%) das Principais Empresas no Mercado Nacional: Desodorantes - 2009

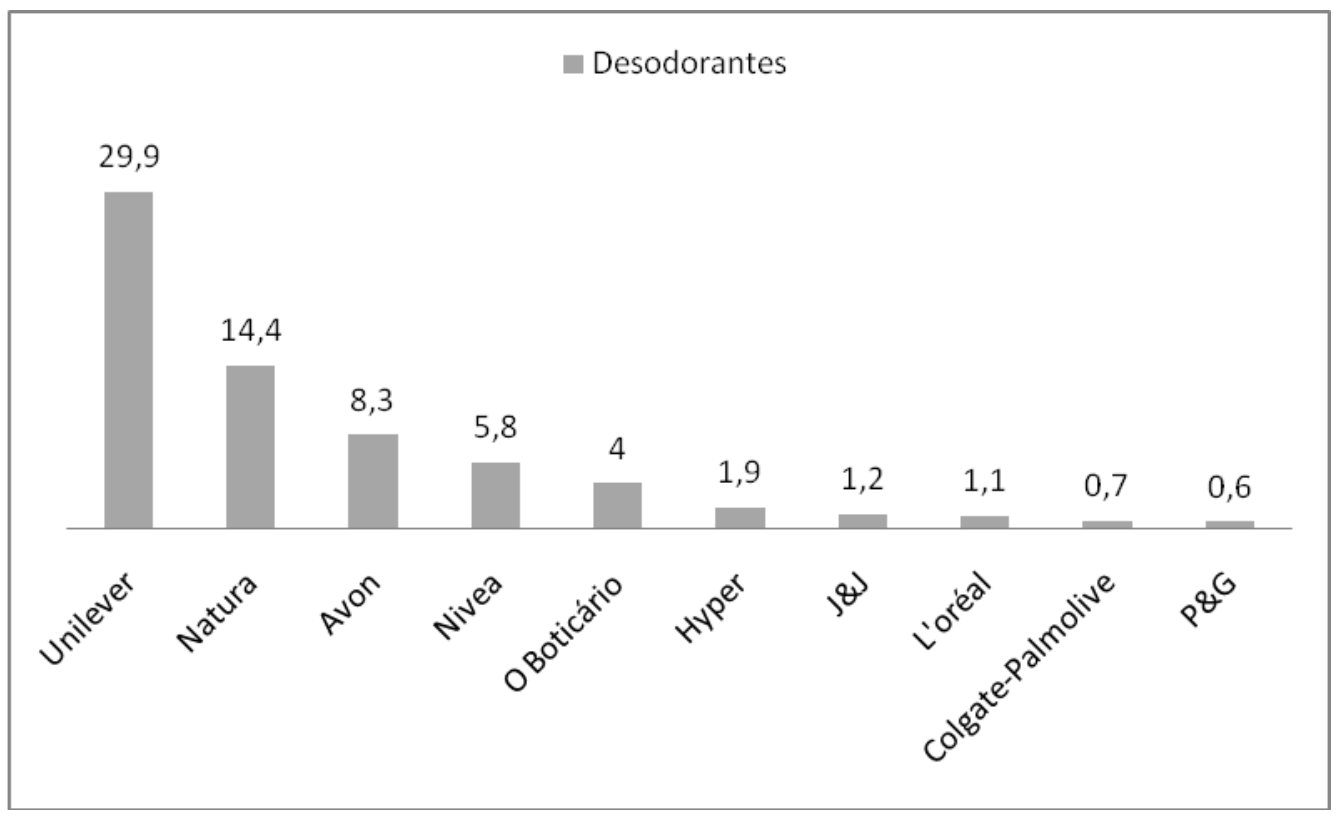

Fonte: EUROMONITOR, 2011. Elaborado pela autora.

Participação (\%) das Principais Empresas no Mercado Nacional: Produtos voltados para o segmento masculino - 2009

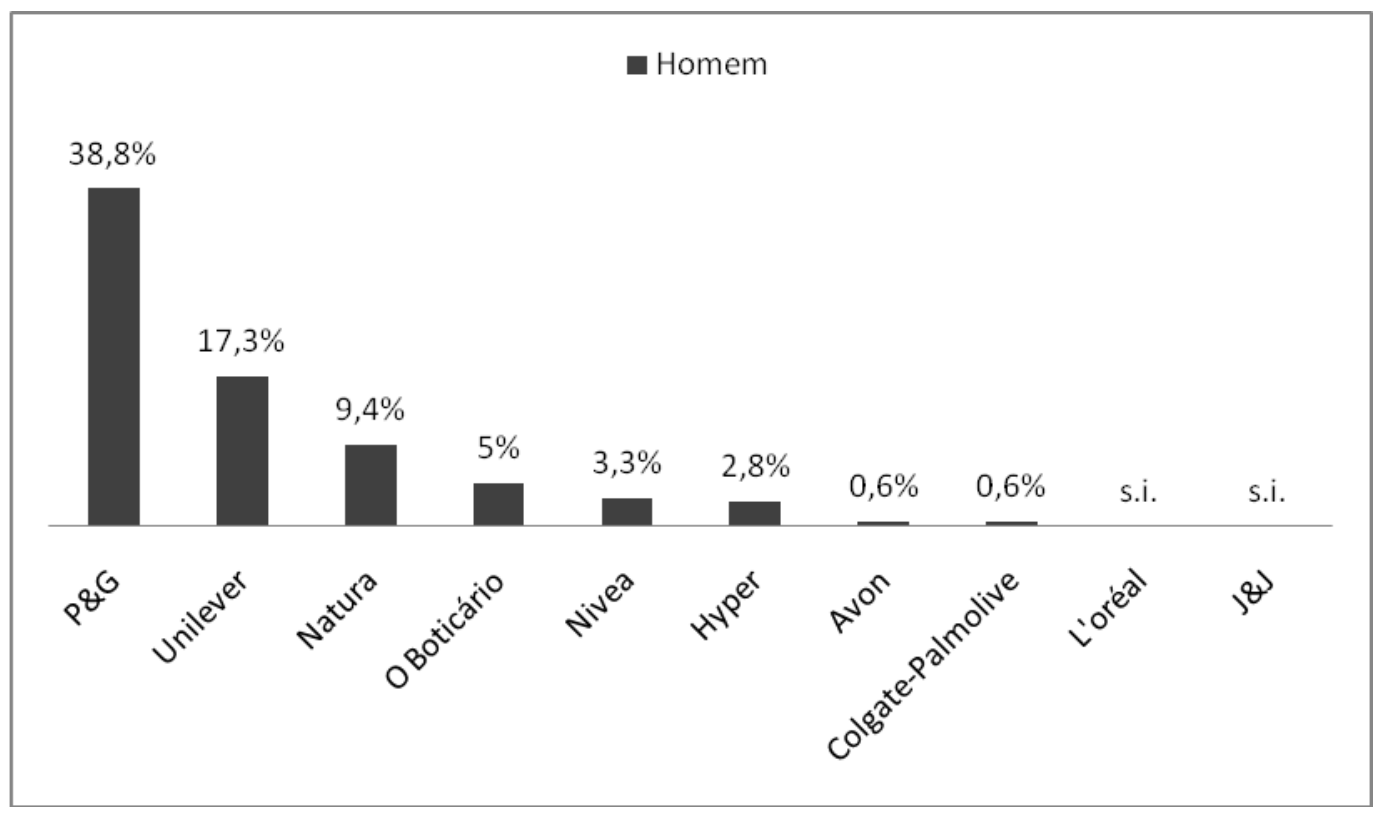

Fonte: EUROMONITOR, 2011. Elaborado pela autora. 


\section{ANEXO 4 - Participacão (\%) das Principais Empresas no Mercado Nacional por grandes subsegmentos - 2009}

Participação (\%) das Principais Empresas no Mercado Nacional: cosméticos cores - 2009

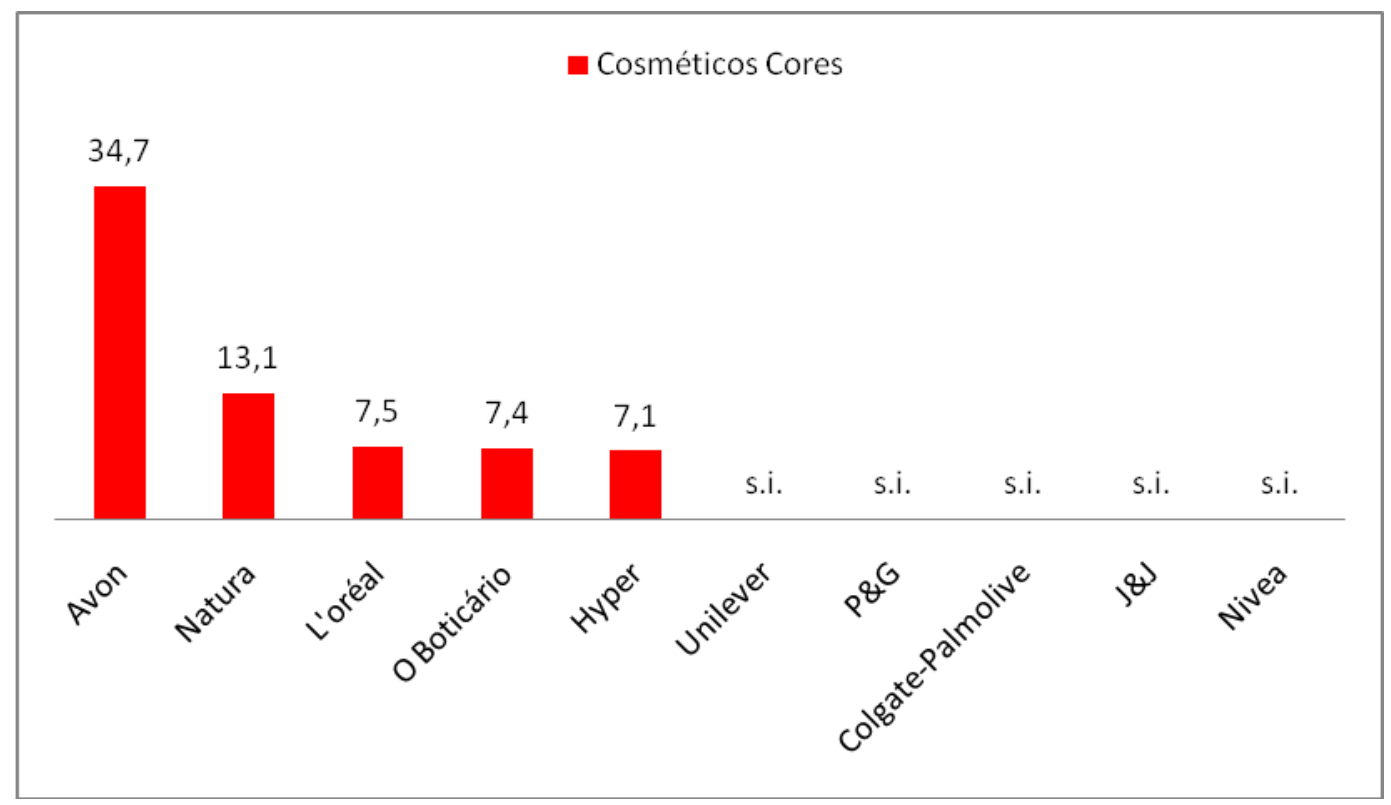

Fonte: EUROMONITOR, 2011. Elaborado pela autora.

Participação (\%) das Principais Empresas no Mercado Nacional: produtos para o cuidado da pele -2009

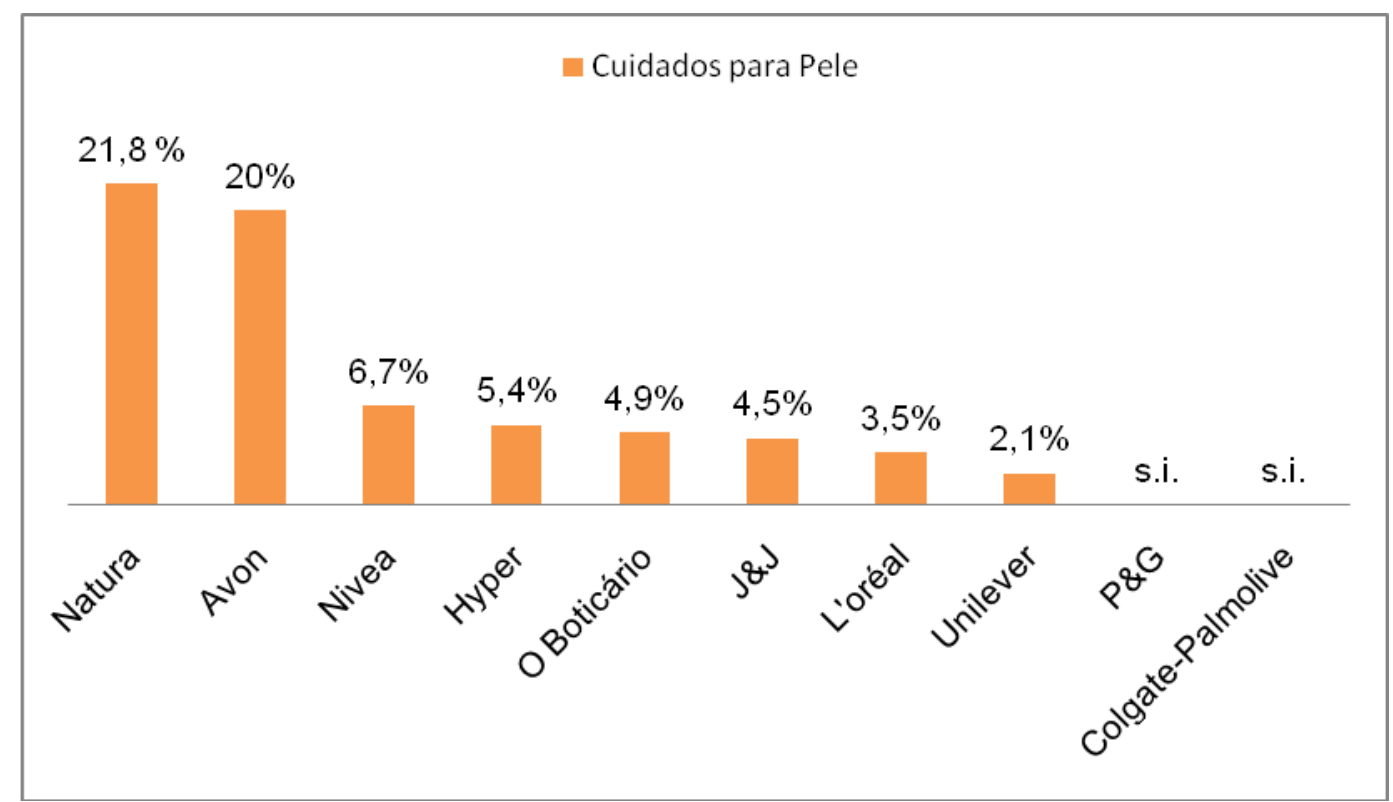

Fonte: EUROMONITOR, 2011. Elaborado pela autora. 
ANEXO 4 - Participacão (\%) das Principais Empresas no Mercado Nacional por grandes subsegmentos - 2009

Participação (\%) das Principais Empresas no Mercado Nacional: fragrâncias - 2009

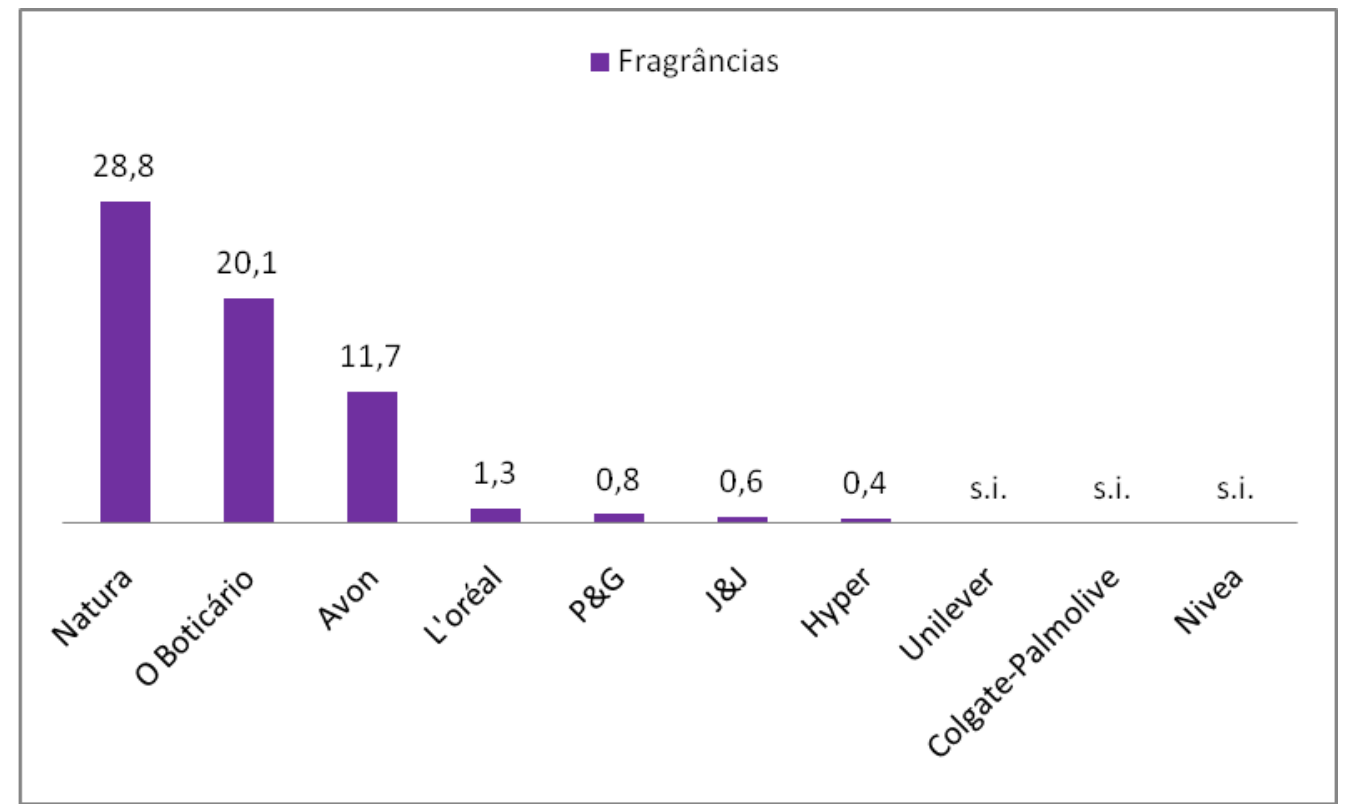

Fonte: EUROMONITOR, 2011. Elaborado pela autora.

Participação (\%) das Principais Empresas no Mercado Nacional:

Protetores solares - 2009

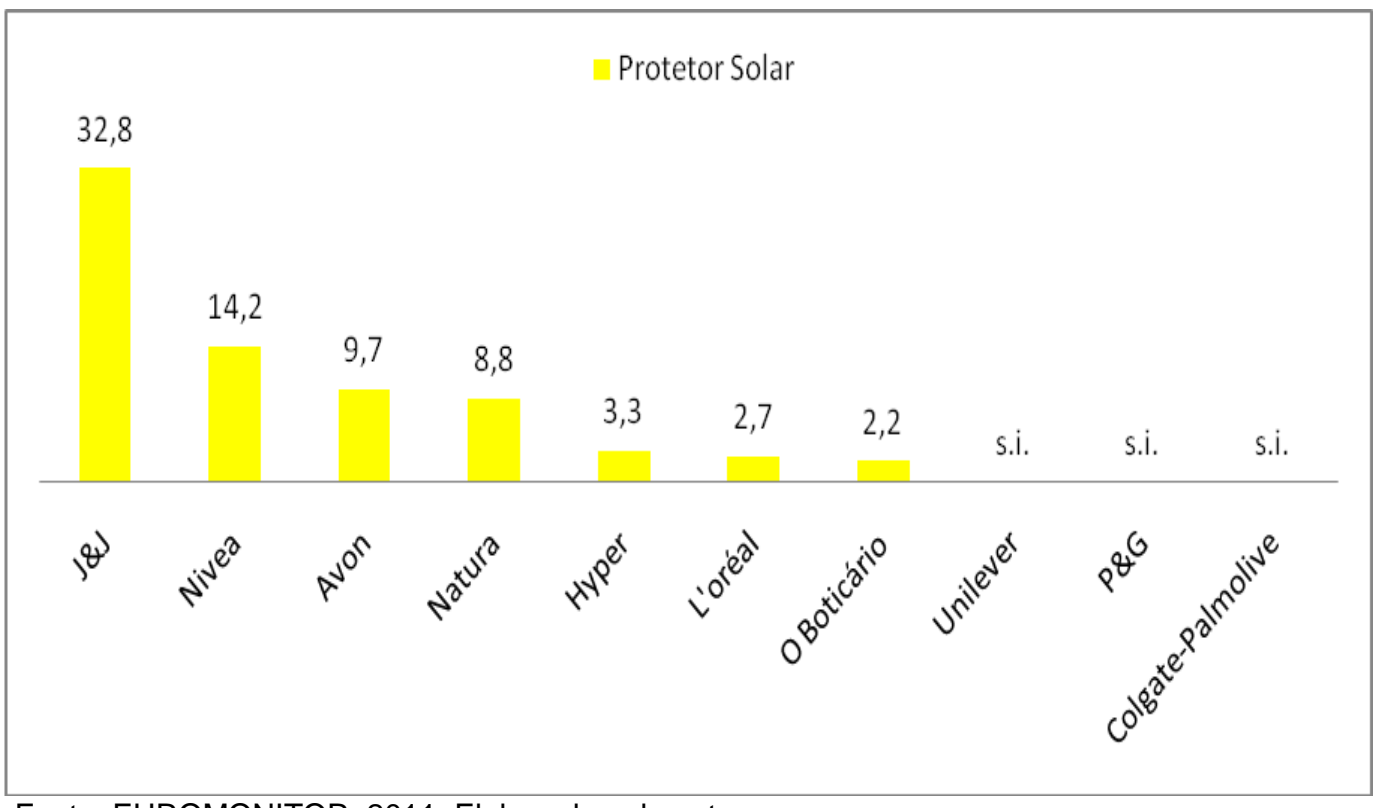

Fonte: EUROMONITOR, 2011. Elaborado pela autora. 


\section{ANEXO 4 - Participacão (\%) das Principais Empresas no Mercado Nacional por grandes subsegmentos - 2009}

Participação (\%) das Principais Empresas no Mercado Nacional: Cosméticos Premium - 2009

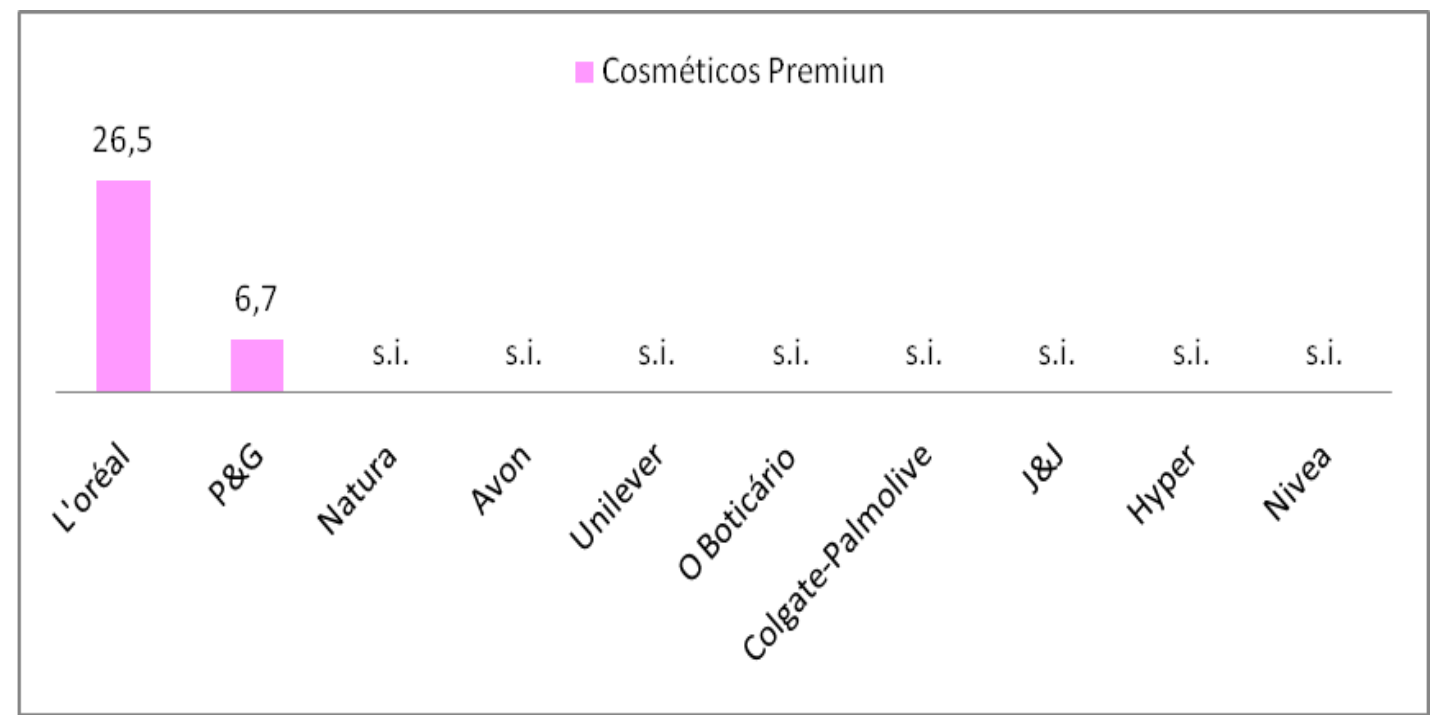

Fonte: EUROMONITOR, 2011. Elaborado pela autora. 


\section{ANEXO 5 - Óleos e Gorduras de Interesse Potencial da Indústria de Cosméticos}

\begin{tabular}{|c|c|c|}
\hline Óleo de Grapefruit & Óleo de Rice Bran & Óleo de Yangu \\
\hline Óleo de Echium & Óleo de Black Walnut & Óleo de Mobola Plum \\
\hline Óleo de Pecan ; & Óleo de Lime Seed & Óleo de Sunflower \\
\hline Óleo de Apricot Kernel & Óleo de Oil Rose hip & Óleo de Chaulmoogra \\
\hline Óleo de Evening Primrose & Óleo de Blackcurrant & Óleo de Moringa \\
\hline Óleo de Pequi & Óleo de Linseed & Óleo de Sweet Almond \\
\hline Óleo de Argan & Óleo de Safflower & Óleo de Cherry kernel \\
\hline Óleo de Grape & Óleo de Borage & Manteiga de Mowrah \\
\hline Óleo de Perilla & Óleo de Macadamia & Óleo de Jojoba \\
\hline Óleo de Artemisia & Óleo de Sacha inchi & Óleo de Chia \\
\hline Óleo de Andiroba & Castanha do Brasil & Murumuru Butter \\
\hline Manteiga de Phulwara & $\begin{array}{l}\text { Manteiga de } \\
\text { Cupuacu }\end{array}$ & Manteiga de Mafura \\
\hline Manteiga de Abacate & Sal seed butter & Óleo de Chiuri \\
\hline Óleo de Hazelnut & Óleo de Buriti & Óleo de Tamanu \\
\hline Óleo de Pistache & Mango Butter & Óleo de Chufa Oil \\
\hline Óleo de Abacate & $\begin{array}{l}\text { Óleo de Sea } \\
\text { Buckthorn }\end{array}$ & Óleo de Ngali \\
\hline Óleo de Yangu & Manteiga de Tree & Tucuma Butter \\
\hline Óleo de Plum Kernel & Óleo de Mango kernel & $\begin{array}{l}\text { Óleo de Cocoa Butter } \\
\text { Olive }\end{array}$ \\
\hline Óleo de Babassu & Óleo de Sesame seed & Óleo de Walnut \\
\hline Manteiga de Illipe & Óleo de Calendula & Óleo de Coffee Bean \\
\hline Óleo de Pomegranate & Óleo de Manketti & Óleo de Papaya Seed \\
\hline Óleo de Baobab & Shea Butter & Óleo de Watermelon \\
\hline $\begin{array}{l}\text { Óleo de Sweet Cherry } \\
\text { Kernel }\end{array}$ & $\begin{array}{l}\text { Óleo de Camelina } \\
\text { (Gold of Pleasure) }\end{array}$ & Óleo de Cranberry \\
\hline Óleo de Poppy & $\begin{array}{l}\text { Óleo de Marigold } \\
\text { Seed }\end{array}$ & Óleo de Passion Fruit \\
\hline Óleo de Bilberry & Óleo de Shea & Óleo de White Mustard \\
\hline Óleo de Kiwi & Óleo de Camellia & Óleo de Kukui \\
\hline Óleo de Pumpkin & Óleo de Marula & Óleo de Peach Kernel \\
\hline Óleo de Bitter Cherry & $\begin{array}{l}\text { Shorea Robusta } \\
\text { Butter }\end{array}$ & Óleo de Ximenia \\
\hline Kokum Butter & Óleo de Cashew Nut & Dhupa Butter \\
\hline Óleo de Raspberry & Óleo de Melão & Óleo de Peanut \\
\hline Óleo de Black Cumin & Óleo de Strawberry & Óleo de Castor \\
\hline
\end{tabular}


ANEXO 6 - Substâncias Suspeitas para Uso Cosmético*

\begin{tabular}{|c|c|c|c|}
\hline Cancerígenos & Alérgicos & $\begin{array}{l}\text { Perturbadores } \\
\text { Endócrinos }\end{array}$ & $\begin{array}{c}\text { Não } \\
\text { Biodegradáveis }\end{array}$ \\
\hline Parabenos & Conservantes & Filtro UV & Silicones \\
\hline Sais de Alumínio & Perfumes & Ftalatos & EDTA \\
\hline Mus & Óleos Essenciais & Parabenos & Quats e poliquats \\
\hline $\begin{array}{l}\text { Conservante BHT e } \\
\text { BHA }\end{array}$ & Parabenos & & Acrylates \\
\hline Éter de glicol & & & $\begin{array}{l}\text { Compostos } \\
\text { orgânicos voláteis }\end{array}$ \\
\hline $\begin{array}{l}\text { Certos } \\
\text { componentes } \\
\text { geneticamente } \\
\text { modificados }\end{array}$ & & & \\
\hline Alguns colorantes & & & \\
\hline Formaldeídos & & & \\
\hline
\end{tabular}

* Muitas dessas substâncias já foram banidas dos produtos da indústria de cosméticos, perfumaria e higiene pessoal, bem como em outros setores industriais.

Fonte: BAURES, C. et al., 2009. 
ANEXO 7- Principais matérias-primas comercializadas entre os países produtores e a UE - 2002 e 2003

\begin{tabular}{|c|c|c|c|c|c|c|}
\hline \multirow[b]{2}{*}{ Produtos } & \multicolumn{3}{|c|}{2002} & \multicolumn{3}{|c|}{2003} \\
\hline & $\begin{array}{l}\text { Principais } \\
\text { exportadores } \\
\text { (\% do total) } \\
\end{array}$ & $\begin{array}{c}\text { Principais } \\
\text { Importadores da EU }\end{array}$ & $\begin{array}{c}\text { Valor em } \\
\text { milhares } \\
\text { (EURO) }\end{array}$ & $\begin{array}{c}\text { Principais } \\
\text { exportadores } \\
\text { (\% do total }) \\
\end{array}$ & $\begin{array}{c}\text { Principais } \\
\text { Importadores da EU }\end{array}$ & $\begin{array}{c}\text { Valor em } \\
\text { milhares } \\
\text { (EURO) }\end{array}$ \\
\hline Óleo de Jasmim & $\begin{array}{l}\text { Índia }(43 \%) \text {, } \\
\text { Egito }(42 \%) \\
\end{array}$ & França $(80 \%)$ & 4,848 & $\begin{array}{l}\text { Índia }(44 \%) \text {, } \\
\text { Egito }(44 \%) \\
\end{array}$ & França $(73 \%)$ & 3,764 \\
\hline Óleo de coco & $\begin{array}{c}\text { Indonésia (50\%), } \\
\text { Filipinas (35\%) }\end{array}$ & $\begin{array}{c}\text { Alemanha (37\%) } \\
\text { Países Baixos (23\%) }\end{array}$ & 557,245 & $\begin{array}{l}\text { Indonésia (44\%), } \\
\text { Filipinas (38\%) }\end{array}$ & $\begin{array}{c}\text { Alemanha (35\%) Países } \\
\text { Baixos }(23 \%)\end{array}$ & 573,941 \\
\hline Óleo de Vetiver & Haiti (85\%) & França $(58 \%)$ & 3,884 & Haiti (83\%) & França (49\%) & 3,855 \\
\hline Óleo de Amendoim & $\begin{array}{l}\text { Senegal }(59 \%) ; \\
\text { Argentina }(21 \%)\end{array}$ & $\begin{array}{l}\text { França }(35 \%) ; \\
\text { Itália }(24 \%)\end{array}$ & 105,998 & $\begin{array}{l}\text { Senegal (41\%), } \\
\text { Argentina (37\%) }\end{array}$ & $\begin{array}{l}\text { França }(39 \%) \\
\text { Itália }(21 \%)\end{array}$ & 112,936 \\
\hline Óleo de Gerânio* & $\begin{array}{l}\text { Egito }(52 \%) \\
\text { China }(46 \%)\end{array}$ & França $(64 \%)$ & 6,618 & $\begin{array}{l}\text { Egito }(56 \%) \text {, } \\
\text { China }(37 \%)\end{array}$ & França (43\%) & 5,275 \\
\hline Óleo de Limão & Argentina (88\%) & Reino Unido (55\%) & 31,100 & Argentina (77\%) & Reino Unido (37\%) & 15,421 \\
\hline Óleo de Lima & $\begin{array}{l}\text { México }(65 \%) \text {, } \\
\text { Peru }(23 \%)\end{array}$ & Reino Unido (45\%) & 8,854 & $\begin{array}{l}\text { México }(66 \%) \text {, } \\
\text { Peru }(24 \%)\end{array}$ & Reino Unido (43\%) & 9,134 \\
\hline $\begin{array}{l}\text { Outros Óleos } \\
\text { Essenciais }\end{array}$ & $\begin{array}{c}\text { China }(27 \%) ; \\
\text { Indonésia (16\%) }\end{array}$ & $\begin{array}{c}\text { França (33\%); } \\
\text { Reino Unido (18\%) }\end{array}$ & 136,301 & $\begin{array}{c}\text { China (28\%), } \\
\text { Indonésia (14\%) }\end{array}$ & $\begin{array}{c}\text { França (31\%); } \\
\text { Reino Unido (17\%); } \\
\text { Alemanha (18\%); }\end{array}$ & 112,421 \\
\hline Ceras & $\begin{array}{l}\text { Brasil (48\%), } \\
\text { China (29\%) }\end{array}$ & Alemanha (28\%) & 19,195 & $\begin{array}{c}\text { Brasil }(40 \%) \text {, } \\
\text { China }(39 \%)\end{array}$ & $\begin{array}{l}\text { Alemanha }(29 \%) ; \\
\text { França }(19 \%)\end{array}$ & 16,365 \\
\hline
\end{tabular}




\begin{tabular}{|c|c|c|c|c|c|c|}
\hline $\begin{array}{l}\text { Plantas Medicinais e } \\
\text { Aromáticas }\end{array}$ & $\begin{array}{l}\text { China (16\%); } \\
\text { Índia (13\%) }\end{array}$ & $\begin{array}{l}\text { Alemanha }(26 \%) \\
\text { França }(17 \%)\end{array}$ & 127,519 & $\begin{array}{l}\text { China (17\%); } \\
\text { Índia (10\%) }\end{array}$ & $\begin{array}{l}\text { Alemanha }(26 \%) ; \\
\text { França }(13 \%)\end{array}$ & 138,141 \\
\hline $\begin{array}{l}\text { Algas e Plantas } \\
\text { marítimas }\end{array}$ & $\begin{array}{c}\text { Filipinas }(34 \%), \\
\text { Chile }(20 \%) \\
\end{array}$ & $\begin{array}{c}\text { França }(22 \%) ; \\
\text { Dinamarca }(22 \%)\end{array}$ & 24,794 & $\begin{array}{l}\text { Filipinas (31\%), } \\
\text { China(17\%) }\end{array}$ & $\begin{array}{l}\text { Reino Unido }(20 \%) \\
\text { Dinamarca }(22 \%)\end{array}$ & 21,913 \\
\hline $\begin{array}{l}\text { Manteiga e óleo de } \\
\text { cacau }\end{array}$ & $\begin{array}{c}\text { Costa do Marfim } \\
(42 \%)\end{array}$ & $\begin{array}{l}\text { Alemanha }(25 \%) \\
\text { França }(21 \%)\end{array}$ & 292,722 & $\begin{array}{c}\text { Costa do Marfim } \\
(44 \%)\end{array}$ & $\begin{array}{l}\text { Alemanha }(23 \%) ; \\
\text { Bélgica }(18 \%)\end{array}$ & 372,185 \\
\hline $\begin{array}{l}\text { Outros Óleos } \\
\text { Essenciais de } \\
\text { cítricos }\end{array}$ & $\begin{array}{l}\text { Cuba }(41 \%), \\
\text { Tunísia }(16 \%)\end{array}$ & $\begin{array}{l}\text { Alemanha }(21 \%) \\
\text { Irlanda }(19 \%)\end{array}$ & 3,478 & $\begin{array}{l}\text { Cuba }(29 \%) \\
\text { Brasil }(23 \%)\end{array}$ & $\begin{array}{l}\text { Alemanha }(23 \%) ; \\
\text { França }(18 \%)\end{array}$ & 3,343 \\
\hline
\end{tabular}

* Gerânio: Bot 1 Gênero (Geranium) de plantas, da família das Geraniáceas, constituído de cerca de 250 espécies cosmopolitas, muitas das quais cultivadas em razão de seu aspecto ornamental. As flores são, geralmente, vermelhas, roxas, róseas ou brancas. 2 Qualquer planta desse gênero. G.-brasileiro: nome de duas plantas geraniáceas (Erodium geoides e Geranium brasiliense). G.-rosa: planta geraniácea ornamental (Pelargonium capitatum). G.-sanguíneo: planta geraniácea ornamental e medicinal (Geranium sanguineum). Var: girame (Fonte: Dicionário Michaelis). Fonte: CBI, 2005. 
ANEXO 8 - Certificação de Ativos da Natura - 2010

\begin{tabular}{|c|c|c|c|c|c|c|c|c|}
\hline Atros/Bics (Exado) & Intcio & Final & Inido & Final & Inido & Final & \multicolumn{2}{|c|}{ Statarna de Produçso } \\
\hline Conopa guianervis (AM) & $\mathrm{x}$ & $\mathrm{x}$ & $\mathrm{x}$ & & & & \multicolumn{2}{|l|}{ Mancjo tradicional } \\
\hline $\begin{array}{l}\text { Açi } \\
\text { Euterpe precatoria }(R D)\end{array}$ & $\mathrm{x}$ & $\mathrm{x}$ & $\mathrm{x}$ & $\mathrm{x}$ & $\mathrm{x}$ & $\mathrm{x}$ & \multicolumn{2}{|c|}{ Soterna agroflorestal SAN } \\
\hline $\begin{array}{l}\text { Capin limbio (P) } \\
\text { Cymbopogon atratus (PR } \in \text { SP) }\end{array}$ & $\mathrm{x}$ & $\mathrm{x}$ & $\mathrm{x}$ & $\mathrm{x}$ & $\mathrm{x}$ & $\mathrm{x}$ & Cutivo & ECOCERT \\
\hline $\begin{array}{l}\text { Castarta do Brail } \\
\text { Bertholetia exreba (AP) }\end{array}$ & $\mathrm{x}$ & $\mathrm{x}$ & $\mathrm{x}$ & $\mathrm{x}$ & $\mathrm{X}$ & $\mathrm{x}$ & Manejo tradicional & Imaflora \\
\hline $\begin{array}{l}\text { Ganus } \\
\text { Theobroma cacos (BA) }\end{array}$ & $\mathrm{x}$ & $\mathrm{x}$ & $\mathrm{x}$ & $\mathrm{x}$ & $\mathrm{x}$ & $\mathrm{x}$ & \multicolumn{2}{|c|}{ Secterna aproflorestal IBD } \\
\hline $\begin{array}{l}\text { Bres } \\
\text { Protium polidurn (AP) }\end{array}$ & $\mathrm{x}$ & $\mathrm{x}$ & $\mathrm{x}$ & $\mathrm{x}$ & $\mathrm{x}$ & $\mathrm{x}$ & Manejo tradioional & Imaflora \\
\hline $\begin{array}{l}\text { Gipuapu } \\
\text { Theobroma pranctilarum (RO) }\end{array}$ & $\mathrm{x}$ & $\mathrm{x}$ & $x$ & $\mathrm{x}$ & $\mathrm{X}$ & $\mathrm{x}$ & \multicolumn{2}{|c|}{ Seterna agrofloretal SAN } \\
\hline $\begin{array}{l}\text { Maracipi } \\
\text { Passiflora edulis (MG) }\end{array}$ & $\mathrm{x}$ & $\mathrm{x}$ & & & & & \multicolumn{2}{|l|}{ Cutivo } \\
\hline $\begin{array}{l}\text { Mute-verde } \\
\text { lex parrovaiensis (RS) }\end{array}$ & $\mathrm{x}$ & $\mathrm{x}$ & $\mathrm{x}$ & $\mathrm{x}$ & $\mathrm{x}$ & $\mathrm{x}$ & Manejo tradicional & Imaflora \\
\hline $\begin{array}{l}\text { Murumuru } \\
\text { Astrocaryum murumuru ( }(M) \text { ) }\end{array}$ & $x$ & $\mathrm{x}$ & $\mathrm{x}$ & & & & \multicolumn{2}{|l|}{ Manejo tradicional } \\
\hline $\begin{array}{l}\text { Prtanga } \\
\text { Euponia urifilono (SP e PFy }\end{array}$ & $\mathrm{x}$ & $\mathrm{x}$ & $x$ & $\mathrm{x}$ & $\mathrm{x}$ & $\mathrm{x}$ & $\begin{array}{l}\text { Cultivo e manejo } \\
\text { orgininico }\end{array}$ & ECOCENT \\
\hline $\begin{array}{l}\text { Priprioca } \\
\text { Cyperus articulatus (PA) }\end{array}$ & $\mathrm{x}$ & $\mathrm{x}$ & $\mathrm{x}$ & $\mathrm{x}$ & $\mathrm{x}$ & $\mathrm{x}$ & Cultivo & $\mathrm{IBD}$ \\
\hline & FASE I & & FASE II & & FASEIII & & & \\
\hline Abros:Outrss linhas & Inicio & Final & Inido & Final & Inido & Find & \multicolumn{2}{|l|}{ Obesernaçoes } \\
\hline $\begin{array}{l}\text { CafeVerde } \\
\text { Coffor andica }(M G)\end{array}$ & $\mathrm{x}$ & $\mathrm{x}$ & $\mathrm{x}$ & $\mathrm{x}$ & $\mathrm{X}$ & $\mathrm{x}$ & Cutivo & SAN \\
\hline $\begin{array}{l}\text { Maracija Doce } \\
\text { Passilara aloto (SP) }\end{array}$ & $\mathrm{x}$ & $\mathrm{x}$ & $\mathrm{x}$ & $\mathrm{x}$ & $\mathrm{X}$ & $\mathrm{X}$ & Cutivo & IBD \\
\hline $\begin{array}{l}\text { Paramela } \\
\text { Adernia burunioides (Potapchio, Arpentina) }\end{array}$ & $\mathrm{x}$ & $\mathrm{X}$ & $\mathrm{x}$ & $\mathrm{x}$ & $\mathrm{X}$ & $\mathrm{x}$ & Manejo & OLA \\
\hline $\begin{array}{l}\text { Pecjo } \\
\text { Ginilla palloides (RS) }\end{array}$ & $\mathrm{x}$ & $x$ & $x$ & $\mathrm{x}$ & $\mathrm{x}$ & $\mathrm{x}$ & Cultivo & ECOCERT \\
\hline $\begin{array}{l}\text { Camvita } \\
\text { Copernicia ceriforo (RW) }\end{array}$ & $\mathrm{x}$ & $x$ & $\mathrm{x}$ & $x$ & $\mathrm{x}$ & $\mathrm{x}$ & Manejo & IBD \\
\hline
\end{tabular}




\begin{tabular}{|c|c|c|c|c|c|c|c|c|}
\hline \multirow[b]{2}{*}{ AthoodOutress Inhas } & \multirow{2}{*}{$\begin{array}{l}\text { FASEI } \\
\text { InIdo }\end{array}$} & \multirow[b]{2}{*}{ Final } & \multirow{2}{*}{ FASE II } & \multirow[b]{2}{*}{ Final } & \multirow{2}{*}{$\begin{array}{l}\text { FASE II } \\
\text { Inicio }\end{array}$} & \multirow[b]{2}{*}{ Final } & \multirow[b]{2}{*}{ Obsarvapoes } & \\
\hline & & & & & & & & \\
\hline $\begin{array}{l}\text { Copratur } \\
\text { Copaifora spp (AM) }\end{array}$ & $\mathrm{x}$ & $\mathrm{x}$ & $\mathrm{x}$ & $\mathrm{x}$ & $x$ & $\mathrm{x}$ & Cultivo argínico & ECOCEIT \\
\hline $\begin{array}{l}\text { Chailverde (F) } \\
\text { Cornelia sineress (PF) }\end{array}$ & $\mathrm{x}$ & $\mathrm{x}$ & $\mathrm{x}$ & $\mathrm{x}$ & $\mathrm{x}$ & $\mathrm{x}$ & Manejo & ECOCEIT \\
\hline $\begin{array}{l}\text { Cindei } \\
\text { Erananthus erythropappus (MG) }\end{array}$ & $\mathrm{x}$ & $\mathrm{x}$ & $\mathrm{x}$ & $\mathrm{x}$ & $\mathrm{x}$ & $\mathrm{x}$ & Manejo & Imaflora \\
\hline $\begin{array}{l}\text { Meiman (F) } \\
\text { Melisa afficinals (PR) }\end{array}$ & $\mathrm{x}$ & $\mathrm{x}$ & $\mathrm{x}$ & $\mathrm{x}$ & $x$ & $\mathrm{x}$ & Cultivo argínico & ECOCEIT \\
\hline $\begin{array}{l}\text { Carqueja (F) } \\
\text { Bacharis peristeblides DC (PR) }\end{array}$ & $\mathrm{x}$ & $\mathrm{x}$ & $\mathrm{x}$ & $\mathrm{x}$ & $\mathrm{x}$ & $\mathrm{x}$ & $\begin{array}{l}\text { Ciltivo } \\
\text { orpánico }\end{array}$ & ECOCERT \\
\hline $\begin{array}{l}\text { Hortek }(F) \\
\text { Mertha piperita L (PR) }\end{array}$ & $\mathrm{x}$ & $\mathrm{x}$ & $\mathrm{x}$ & $\mathrm{x}$ & $\mathrm{x}$ & $\mathrm{x}$ & $\begin{array}{l}\text { Cultivo } \\
\text { orparico }\end{array}$ & ECOCERT \\
\hline $\begin{array}{l}\text { Camomila (F) } \\
\text { Chamomila recutita (PF) }\end{array}$ & $\mathrm{x}$ & $\mathrm{x}$ & $\mathrm{x}$ & $\mathrm{x}$ & $\mathrm{x}$ & $\mathrm{x}$ & Gutivo orgatico & ECOCERT \\
\hline $\begin{array}{l}\text { Funcho }(\mathrm{F}) \\
\text { Foeniculum wulpare Mllar (PR) }\end{array}$ & $\mathrm{x}$ & $\mathrm{x}$ & $x$ & $\mathrm{x}$ & $\mathrm{x}$ & $x$ & $\begin{array}{l}\text { Ciltivo } \\
\text { orgápico }\end{array}$ & ECOCEII \\
\hline $\begin{array}{l}\text { Crnela (F) } \\
\text { Grnamarnum reylaricum Nes (Albrnanha) }\end{array}$ & $\mathrm{x}$ & $x$ & $\mathrm{x}$ & $\mathrm{x}$ & $\mathrm{x}$ & $\mathrm{x}$ & $\begin{array}{l}\text { Giltivo } \\
\text { orgárico }\end{array}$ & $\mathbb{M O}$ \\
\hline $\begin{array}{l}\text { Crovo ch inda (F) } \\
\text { Carpophylus aromotias L (BA eAlemanha) }\end{array}$ & $\mathrm{x}$ & $x$ & $x$ & $x$ & $\mathrm{x}$ & $\mathrm{x}$ & $\begin{array}{l}\text { Cutivo } \\
\text { ortápico }\end{array}$ & IMO \\
\hline $\begin{array}{l}\text { Rosa Mosqueda (F) } \\
\text { Rosa carina L (Alernarha) }\end{array}$ & $\mathrm{x}$ & $\mathrm{x}$ & $\mathrm{x}$ & $\mathrm{x}$ & $\mathrm{x}$ & $x$ & $\begin{array}{l}\text { Cultivo } \\
\text { orgánico }\end{array}$ & $\mathbb{M O}$ \\
\hline $\begin{array}{l}\text { Jarrbu } \\
\text { Spilarthes olerocen (SP) }\end{array}$ & $\mathrm{x}$ & $x$ & $x$ & $\mathrm{x}$ & $\mathrm{x}$ & $x$ & $\begin{array}{l}\text { Cultivo } \\
\text { orgárico }\end{array}$ & IBD \\
\hline $\begin{array}{l}\text { Etaraque } \\
\text { Ocinum anericanum (PA) }\end{array}$ & $\mathrm{x}$ & $x$ & $\mathrm{x}$ & $\mathrm{x}$ & $\mathrm{x}$ & $\mathrm{x}$ & $\begin{array}{l}\text { Cultivo } \\
\text { orgánico }\end{array}$ & IBD \\
\hline
\end{tabular}

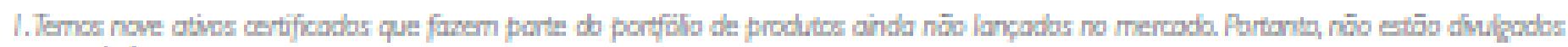
nesta tabela.

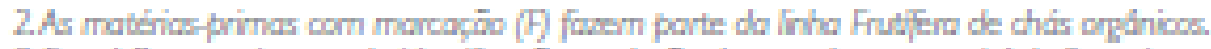

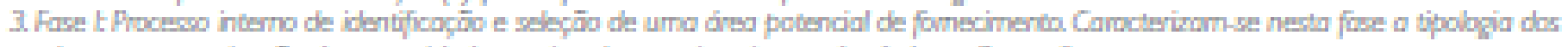

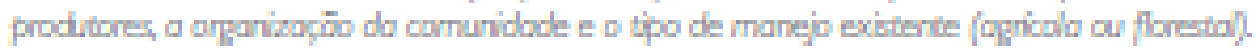

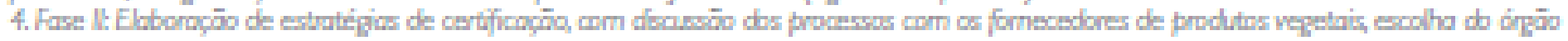

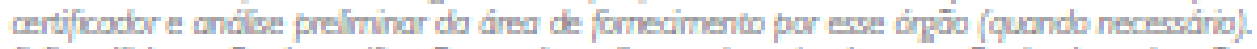

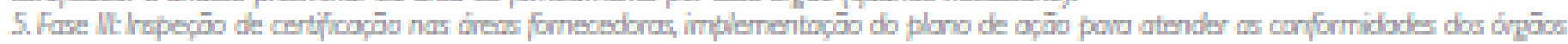

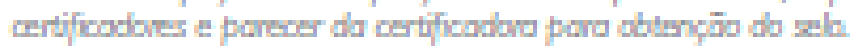

$=$

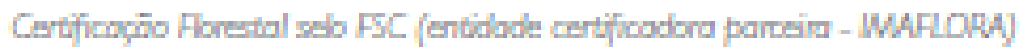

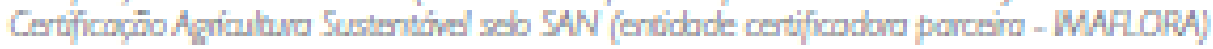

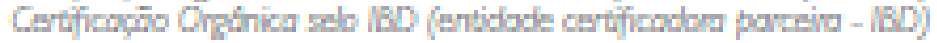

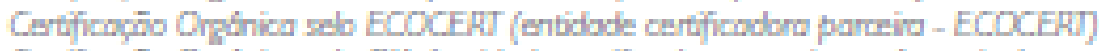

Getifirsio Oránica reb OA (entidade aerticadora parciva na Arentina)

Certfimpio Orpinica seb MO (entidade certifoodons parreir - MO)

Fonte: Natura, 2011. 


\section{ANEXO 9 - Principais insumos fornecidos pela BERACA}

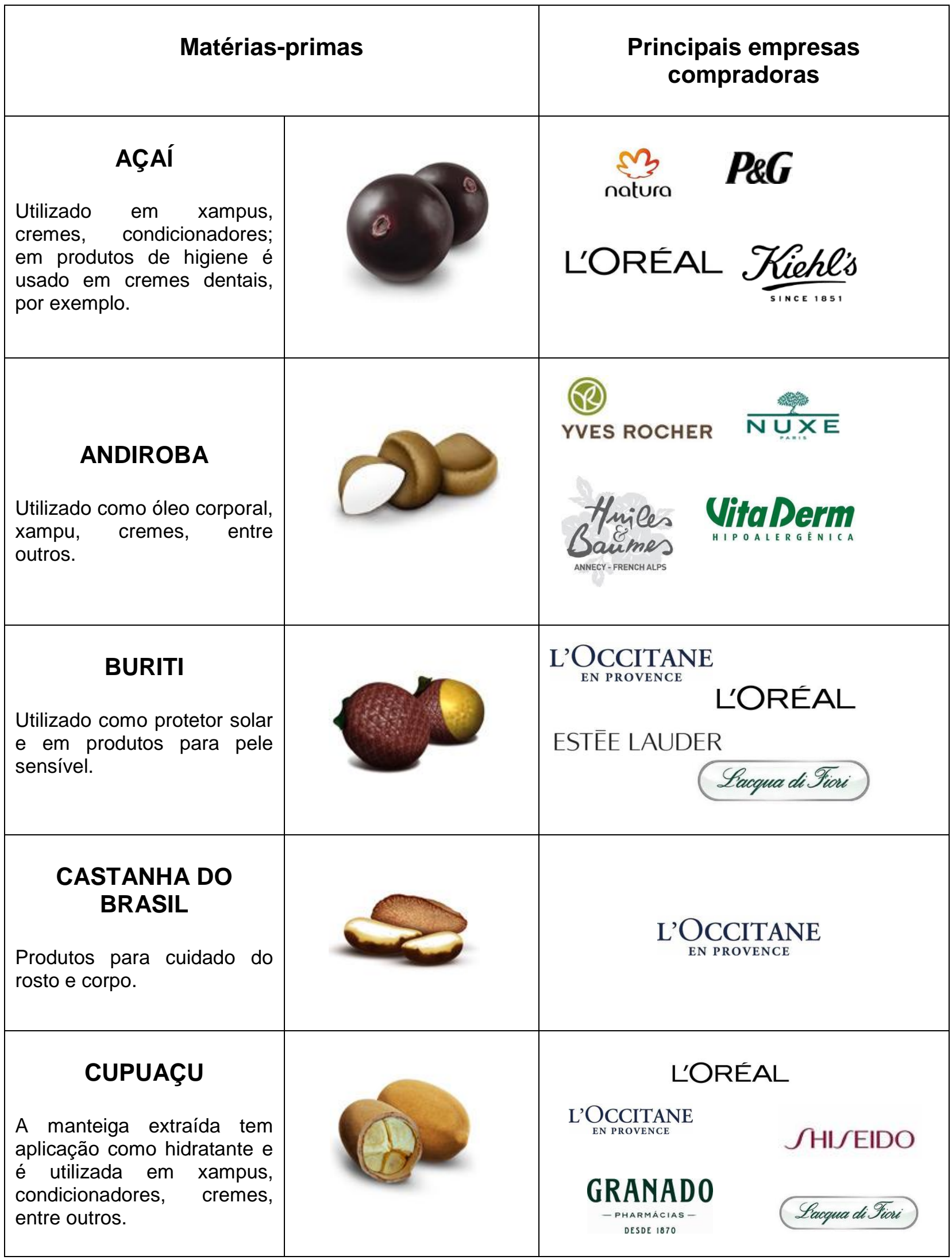




\begin{tabular}{|l|l|l|}
\hline \multicolumn{1}{|c|}{ MURUMURU } \\
$\begin{array}{l}\text { Fabricação de sabonetes e } \\
\text { cremes. }\end{array}$ \\
\multicolumn{1}{|l|}{ PRACAXI } \\
$\begin{array}{l}\text { Utilizado em produtos para } \\
\text { os cabelos e corpo. }\end{array}$ \\
\end{tabular}

Fonte: Beraca Sabára, 2011. Elaboração da Autora, 2011. 